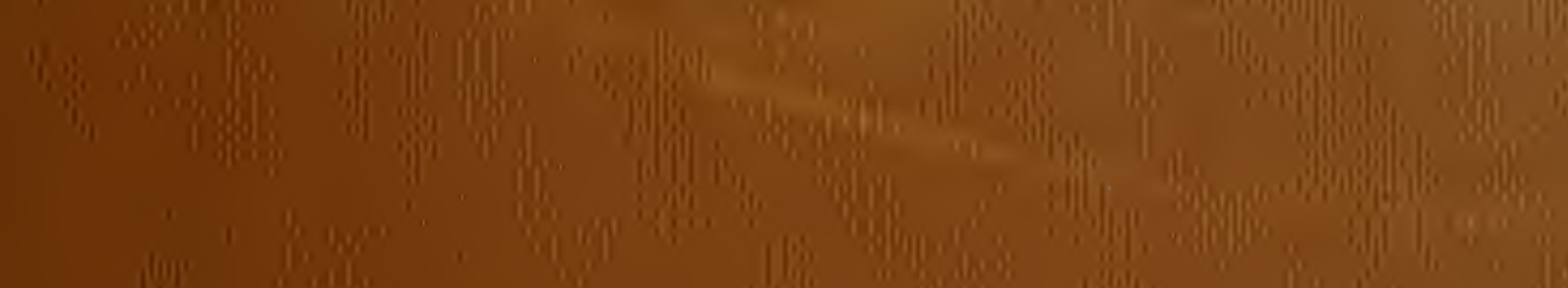
S

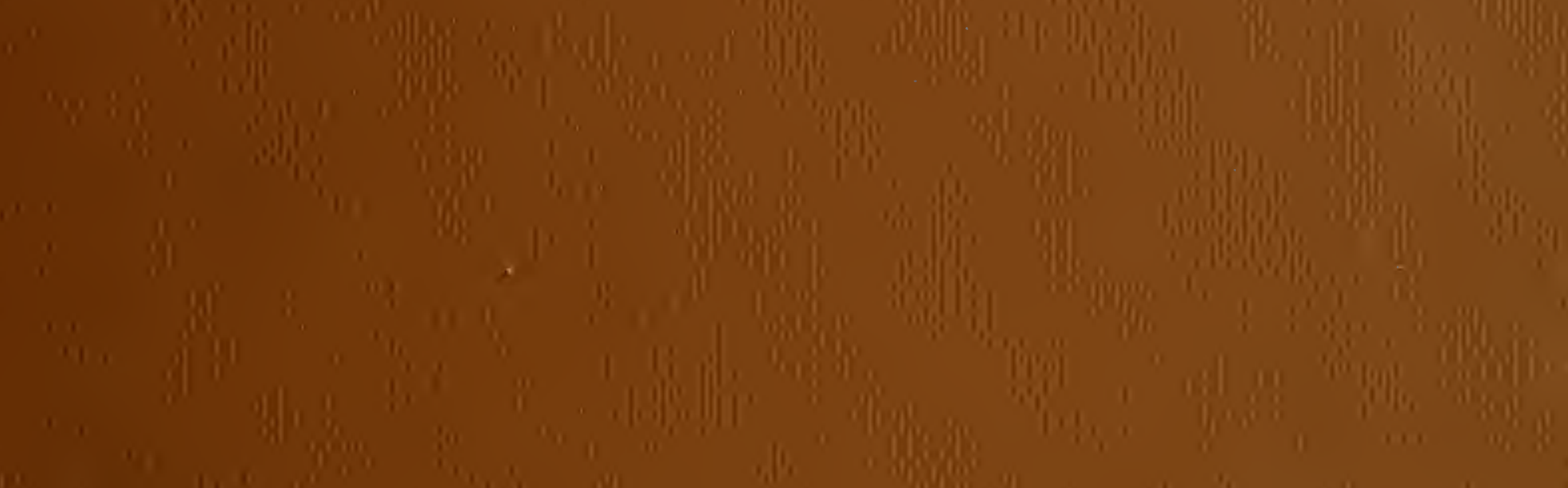
(1) in (n) an (1) on

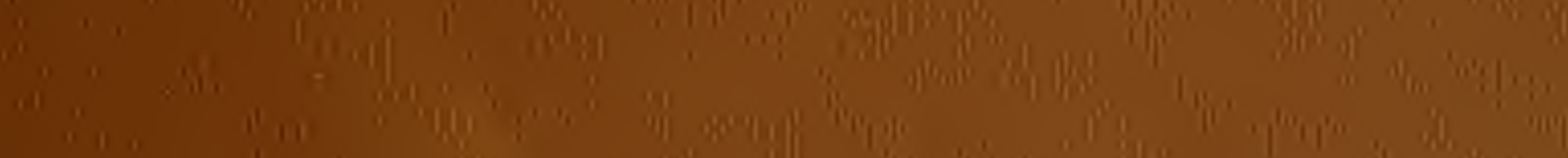
(1) (1) (n)

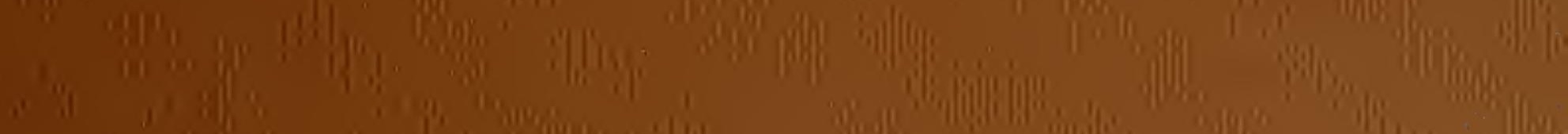

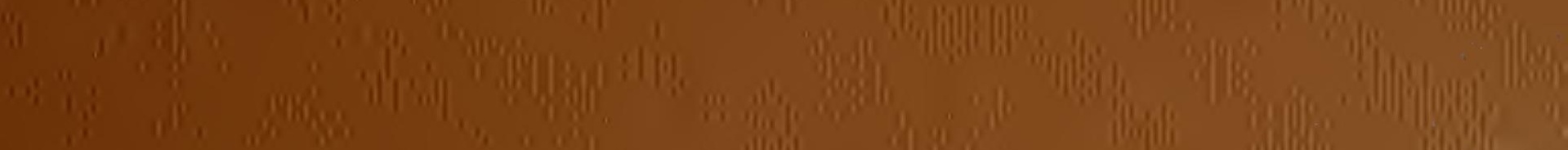

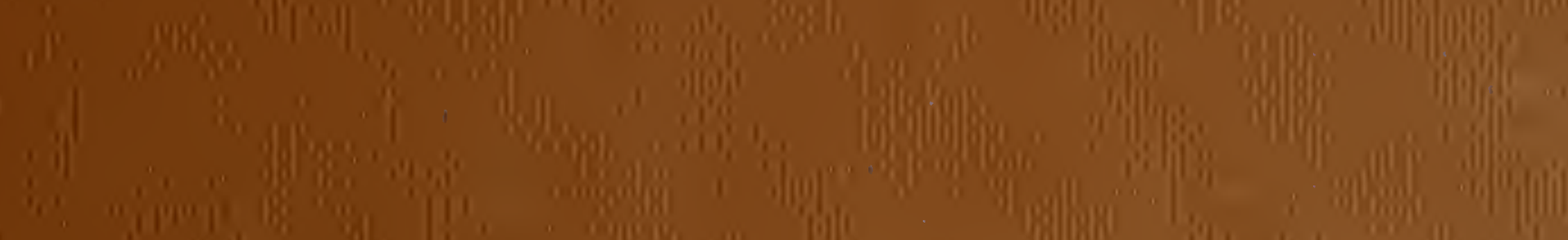
3. 等

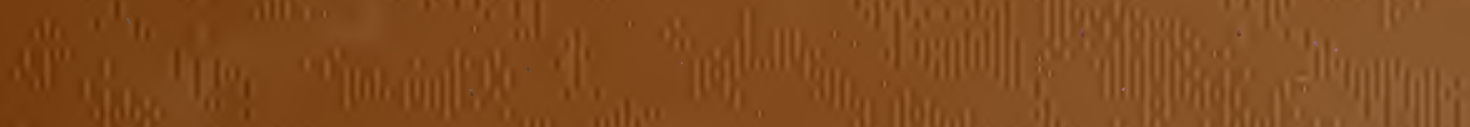
إ) 
HARVARD UNIVERSITY

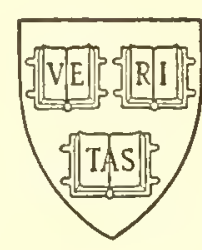

LIBRARY

OF THE

Museum of Comparative Zoölogy 
ta 



68.72 .9

Memoirs of the MDuseum of Comparative zoology

AT HARVARD COLLEGE.

Yol. XLY. No. 1.

REPORTS ON THE SCIENTIFIC RESULTS OF THE EXPEDITION TO THE TROPICAL PACIFIC, IN CHARGE OF ALEXANDER AGASSIZ, BY TIIE U. S. FISH COMMISSION STEAMER “ALBATROSS," FROM ALGLST, 1S99, to JUNE, 1900, COMMANDER JEFFERSON F. IIOSER, U. S. N., CONMANDING.

XIV.

THE SOLENOGASTRES.

BY HAROLD HEATH.

WITH FORTY PLATES.

[Published by permission of George M. Bowers, U. S. Commissioner of Fish and Fisheries.]

CAMBridge, U. S. A.:

printed for the Mousellu.

JUNE, 1911. 


\section{TROPICAL P'ACIFIC!}

The following I'ublimtions of the Museum contuin Reports on the Dredging Operations in

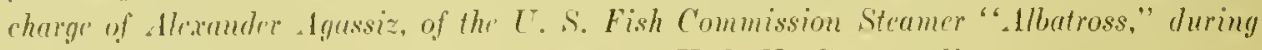
1599 and 1900. Commander , Jeffereon F. Hosrr, L. S. N., Commanding.

1. 1. Acikstz. Preliminary Report and List of Stations. With Remarks on the DeepSea Deposits by Sir John Murray. Mem. M. C. Z., Vol. XXYT. No.1. January, $1902.211 \mathrm{pp} . \quad 21$ (Charts.

II. A. G. Marer. Some Species of Partula from Tahiti. A Study in Yariation. Mem. II. (. Z., Yol. XXY1. No. 2. Jamuary, 1902. 21 pp. 1 Plate.

III. A. Agassiz and A. G. Mager. Meduse. Nem. MI. C. Z., Tol. XXTi. No. 3. Janniry, 1902. 40 pp. 13 Plates. 1 Chart.

IV. A. Agassiz. The Coral Reefs of the Tropical Pacific, IIem. M. C. Z., Vol. XXYIII. Fehrulury, 1903. 33, 410 pp. 23s Plates.

I. C. R. Eastmax. Sharks' Teeth and (ctacean Bones from the Red Clay of the Tropical Pacific. Mem. M. C. Z., Vol. XXYT. No. 4. June, 1903. 14 pp. 3 I'lites.

VI. IV. E. Horte. Cephalopodal. Bull. M. C. Z., Yol. XLIII. No. 1. March, 1904. $71 \mathrm{pp} .12$ Plates.

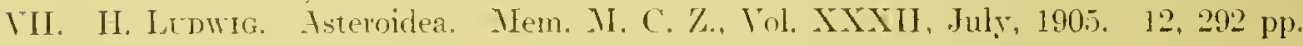
3.5 Plates, 1 Chart.

YIII. W. E. Remter and Edrth S. Byxbee. The Peligic Tunicata. Mem. M. C. Z., Yol. XXY"I. No, 5. August, 190.5, 20 pp. 2P Pates.

IX. Mary J. Ratubex. The Brachyou, Mem. M. C. Z., Vol. XXXY. To. 2. August, 1907. $54 \mathrm{pp}$. 9 Plates.

X. (. H. Gilbert. The Lantern Fishes. Mem. M. (. Z., Vol. XxVI. No. 6. July, 1908. 23 pp. 6 Plates.

XI. A. Agtssiz. Echini. The Genus Colobocentrotus. Nem. M. C. Z., Vol. XXXIX, No. 1. November, 190s. 44 pp. 49 Plates.

XII. J. Mrrray and G. Y. Lee. The depth and marine deposits of the Pacific. Mem. M. C. Z.. Vol. XXXitil, Xo. 1. June, 1909. 170 pp. 5 Plates. 3 Maps.

XII. W. C. Kexdul and E. L. Goldsborutgir. The shore Fishes. Mem. M. C. Z., Vol. KXil. No. 7. Februly, 1911. 100 pp. T Plates.

XIV. H. Heath. The Solenngastres. MIem. MI. (. Z., Vol. XLY. No. 1. June 1911, 150 pp. 40 Plates. 
Memoirs of tbe ADuseum of Comparative zootogl

A T HARVARI COLLEQE.

YoI. XLY. No. 1.

REPORTS ON TIE SCIENTIFIC RESILTS OF TIE EXPEDITION TO THE TROPICAL PACIFIC, IN (HARGE OF ALEXANIER AGASSIZ, BY THE: IT. S. FISII COMMISSION STEAMER “ALBATROSS," FROM AITGUST, 1899, to JINE, 1900, COMMANDER JEFFERSON F. MOSER, U. S. N., COMMANDING.

XIV.

\section{'THE SOLENOGAS'TRES.}

Br HAROLD HEATH.

WITH FORTY PLATES.

[Published hy permission of GEORGE M. BuWERs, U. S. Commissioner of Fish and Fisheries]

(AMHRIJ)GE, I. S. A.:

IDrintes for tbe SDuscum.

JUNE, 1911 .

c. 



\section{TABLE OF CON'TENTS.}

\begin{tabular}{|c|c|c|c|c|c|c|c|c|c|}
\hline & & & & QE. & & & & & $P_{A G E}$ \\
\hline ATRODLCTION & & & & & Halomeni: & & & & - 47 \\
\hline IHSTURICAL REVIEW & & & 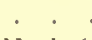 & $\cdot 11$ & Dondersiilas & . & . & & - 45 \\
\hline GINERAL FEATURES, & $M$ & II:T & $11010 \mathrm{~s}$ & & Herpunenthil & • & . & . & 45 \\
\hline ETC. & & & . . & 19 & Dontersia & . & . & & \\
\hline Gxternal Characters & . & . & . &.$\quad 19$ & lehthyomeniat & & . & & \\
\hline J NTERNAL ANATUMY & . & 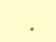 & . & . 19 & DECTRPTION OF SAlEC & IE' & & & 49 \\
\hline MeTHods . . . & . & 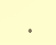 & . & . 23 & Chatotolernat hawaichs & sis . & & . & . $4 !$ \\
\hline OCOERRENCE. & . & & . & 23 & C. attemuitit & . . & . & . & .5 .5 \\
\hline MUDE UF LIFE, FUUD & & 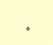 & . & . 21 & C. cruclitit . & . . & . & & .59 \\
\hline Color, size . . & . & 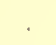 & . & .25 & C. montereyensis. & . . & & . & .61 \\
\hline L_ENGTII INDEX . . & & & . . & - 20 & C. argenteal . . & . . & & & . 102 \\
\hline CON1P.ARATIVE ANATOA & 115 & & . & . $\ddot{\prime \prime}$ & C. seithral & . . & & & .63 \\
\hline FouT ANI fillixus. & & . & & $24 i$ & C. cotlifornica . . . & . . & . & & 6.4 \\
\hline HYPODERMIS AND PRODEC & retsi & 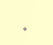 & & 27 & C. Hatnulit . . & . . & . & & . 60 \\
\hline SPICULE DEVELH'MENT & & & & 23 & C $₫$ jilponica & . . & & . & .86 \\
\hline Digestive Tr.eT . & . & 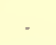 & 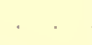 & . $\quad 32$ & C. molustal - & & . & . & . lis \\
\hline MI'SCLLAR MYYSTEM . & . . & ${ }^{\circ}$ & & $\cdot \because 2$ & Linifosiner talpoinleus. & . . & . & . & . lis \\
\hline Promary Bong Cavity A & AND & $S E I^{2}$ & & . $3 ; 3$ & L. fritulit - & . . & . & . & .72 \\
\hline Clrculatory aND Resi & SPIRA & ATert & ar sist & & 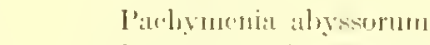 & 1 & . & & . 72 \\
\hline TEMS . . . . & 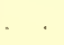 & 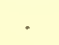 & . . & $.3: 3$ & l)repumemenia vanuy!re & rall:il & . & . & .7 \\
\hline NERVHSS SYSTEM & . & . & . & . 31 & ['Joneonential lawairensi & is . & . & . & . $\quad 52$ \\
\hline SENSE URGANS . & . & . & . . & $.31 ;$ & P' insulatris & . . & . & . & . \\
\hline CiHELOA]. . & . & . & . &.$: 37$ & Dromenia paeilioal. & . & . & & . 93 \\
\hline PHYsionarir & . & . & . & . : & Dorymonia atmotal & . & . & . & 45 \\
\hline CLASIIFICATION & . & & & 41 & Strophomenia scimblems & . & . & & .100 \\
\hline APLACOIIUIRA & . . & . & . & . 12 & $\therefore$ ophlictiana . . . & . . & . & . & .112 \\
\hline Chantolermatidae. & . . & & . & . 12 & S. menularis & & & & .116 \\
\hline Chactolerma. & . . & . & & . 13 & s.. fitreimen & & & & $11 !$ \\
\hline Limifossor & . & . & & 11 & S. spinosit & & & & 122 \\
\hline Someniilate & & . & . & . 41 & $\therefore$ triangularis. & & & & .125 \\
\hline Drepanomeniat &. & . & & . 41 & bophomenia spiralis & & & & 128 \\
\hline l'achyomeni: & & . & & $4 i$ & Alevamlroneniat agassiz & & & & 133 \\
\hline Pronemmeniviae & & & . & 4.5 & 1. valida & & . & & 142 \\
\hline Proneomenia & & & & 1.5 & Italonenia gravicla & & & & 146 \\
\hline Driomenia & & . & & .45 & IIerponenia platyporla & & & & 1.51 \\
\hline Dorymenia & & & & .16 & Dondersia californicia & & & & 155 \\
\hline Strophomenia. & 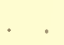 & & & . 46 & 1ehthyomenia porosa & . & & & $1: 9$ \\
\hline Pruvotiniidae . & 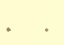 & & & .17 & NERAL CONSIILRAT & TIONS & & & 161 \\
\hline Lophomenia & . . & & . & . 17 & BHBLOCRAPHY & & & & 174 \\
\hline Alexantromenia & & & . . & . $4 \pi$ & FXILANATION OF IJA & TES & & & 180 \\
\hline
\end{tabular}




\section{THE SOLWNOGASTRES.}

\section{INTRODUCTION.}

The present papel embraces the results of the study of a collertion of over three bundred specinens of solenogastres, which have been taken in the Parilic during the rarious expeditions of the U. S. Fish Commision stemer "Albatross." Based primarily on material from the Museum of Comparative Zoölogy, it includes, through the generosity of the late Mr. Alexander Agansiz, the description of other species rollected during recent yours. The territory (mubraced in these explorations is very extensive, including the entire coant of North Ameriea from Lower California to Bering Sea, the Kurile Islands, the Japanese Archipelago, and the Hawaina Islands. The major portion of the material was eollected by the following expeditions: Tropical Pacific, 1899-1900: Hawailan Exploration, 1902; Naska Investigations, 1890 and 1903; California Coast Exploration, 1859 and 1904; Japanese Expedition, 1904.

\begin{tabular}{|c|c|c|c|c|c|}
\hline \multicolumn{2}{|r|}{ APECIES } & STATION & $\begin{array}{c}\text { NEMBER } \\
\text { WF } \\
\text { SHECINESS }\end{array}$ & 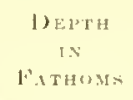 & $L(1) \cdot L I T Y$ \\
\hline \multirow{2}{*}{\multicolumn{2}{|c|}{ Chactoderma argentea }} & 4231 & 1 & $82-113$ & Alaskil, near Niha Bay. \\
\hline & & 4244 & 1 & & \\
\hline \multirow[t]{2}{*}{ “ } & attenuata & 4250 & is & in-201 & " virinity of l'r. Wales lil. \\
\hline & & 4252 & 2 & & \\
\hline “" & californica & $43 \div 1$ & 1 & $118-1867$ & 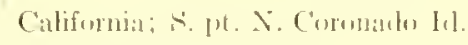 \\
\hline \multirow{2}{*}{ " } & \multirow{2}{*}{ ermulitil } & $1+25$ & 10 & & Mlaskit, Lỵn Canal. \\
\hline & & 1264 & 41 & $2 \times 2-313$ & “C Chatham sitrait. \\
\hline " & lanwailensis & $\left\{\begin{array}{l}30,102 \\
1130\end{array}\right.$ & $\begin{array}{l}1 \\
1\end{array}$ & $24: 5-526$ & Hawaiian Ith : Har hanai ld. \\
\hline \multirow[t]{2}{*}{ ". } & \multirow[t]{2}{*}{ j:1ponis:a } & 3721 & 1 & $20-250$ & Japrun, s. of Honshu hl. \\
\hline & & $t+15$ & 9 & & \\
\hline \multirow[t]{2}{*}{.} & \multirow[t]{2}{*}{ montreyensis } & $\begin{array}{l}4.004 \\
4522-2\end{array}$ & 7 & $3 ! 3-3.516$ & California, Monterey liay. \\
\hline & & 4525 & 139 & & \\
\hline$"$ & namila & 4369 & 1 & $260-284$ & off s:a11 Diego. \\
\hline “ & robusta & 3210 & 4 & 143 & S. of Alanka Penimsulli \\
\hline “" & seabra & $453 x$ & 1 & $79.5-871$ & California, Monterey Bay. \\
\hline
\end{tabular}




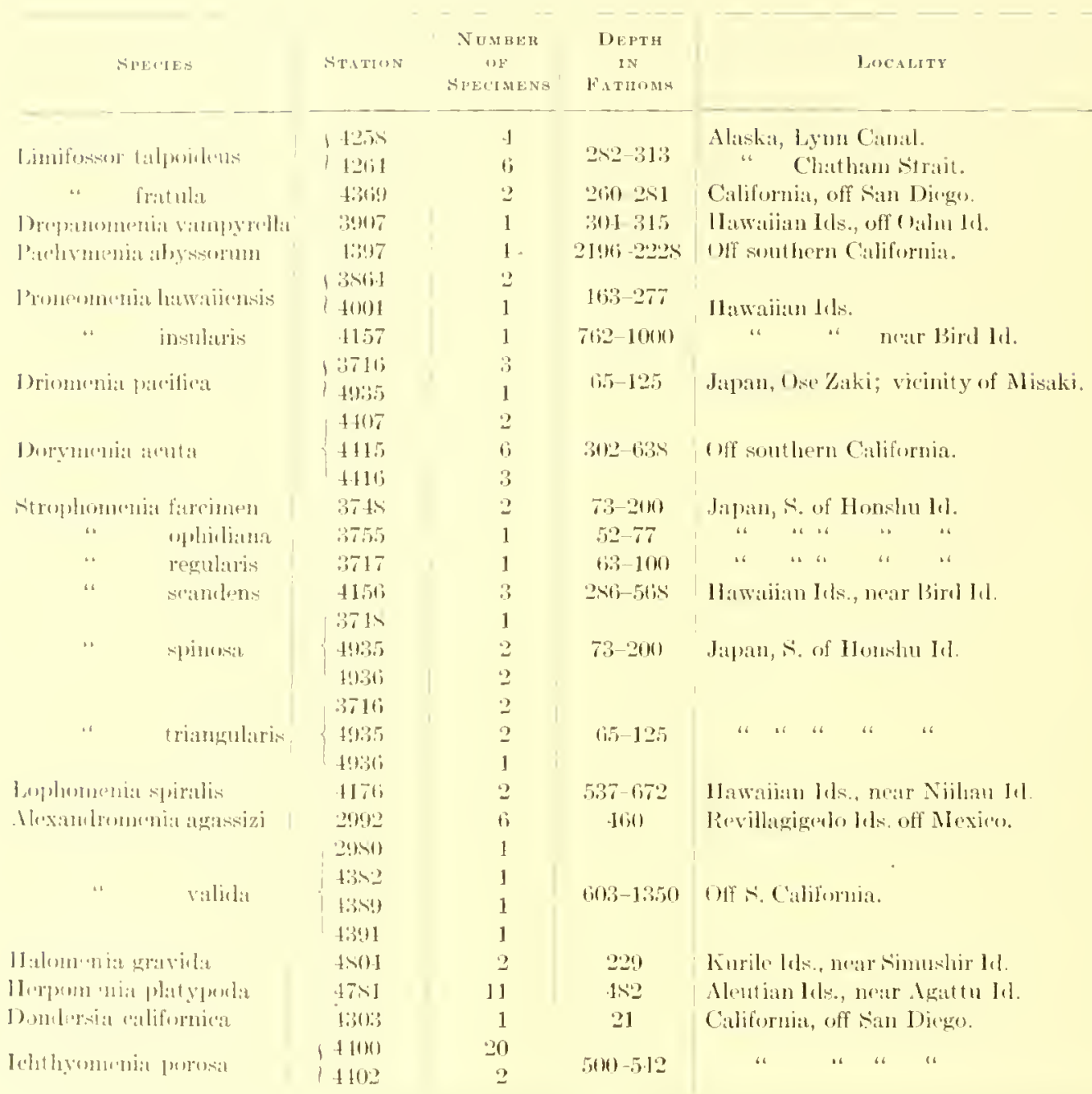

Up to the present time none of these molluses has been described fom the Nonth l'ateific. I few speries ane known to oceur about Australia and the Philippines, and an extensive collection was made in the East Indian Archipelago by the sibuga Expedition. The present collection embraces thirty-ome species of whith all are new with the exreption of Limifossor talpoideus Heath; the speries belong to fourteen genera of which eight are new. Fom this material it beconnes increasingly evident that this gromp of molhuses is cosmopolitam; but there is 10 eridenee of at bipolarity or any indication that the north and south poles were centres of distribution. And furthermore there is no alpuarent relation between size and geographical distribution.

In concluting this section of the paner it beeomes a most pleasant duty to express my obligation to those who have aided in its completion. To Hon. 
C. M. Bowers, Dr. D. S. Jordan, and Dr. C. H. Gilbert I am indebted for a portion of the material, to certain data relating to a few of the species and for many courtesies while on board the "Albatross." I am likewise under deep obligation to Drs. E. J. Nolan and H. A. Pilsbry for the use of the magnificent library of the Philadelphia Academy of scienees, and for several suggestions of a most helpful character. To Dr. W. K. Fisher I am indebted for the identifieation of the alcyonarian hosts and for a specimen of Chectodermu haveriensis. I also wish to express my gratitude to my assistants, Miss R. M. Higley, and Mr. F. W. Weymouth who have greatly lessened the burden necessarily involvod in such a study as this. And finally my indebtedness to the late Mr. Alexander Agassiz is very great; in every way possible he helped the work along.

\section{HISTORICAL REVIEW.}

The first known reference to any species of Solenogastre occurs in the works of Loven, who in 1844 briefly deseribed as a gephyrean worm Chactoderma nitidulum. During the next thirty years a number of systematists adopted this scheme of elassification though there was some difference of opinion concerning the exact position of the species within the group. Diesing (59), Keferstein ('65), Quatrefages ('65), and Baird ('68) allied it to Sipunculus or Priapulus; Theel ('75) created for it a new family (Chaetodemidae), white M. Sars ('69) placed it among the gephyreans without any comment. Dalyell (53) in "The P'owers of the Creator" gives under the name Vermiculus crassus an abbreviated description and one figure of an undoubted chaetoderma, according to Koren and Daniellssen ('77) C. dalyclli, but the description is much too indefinite to make the determination certain.

During this time M. Sars discovered another species of Solenogastre, belonging to a new genus and ultimately to a new family, which he placed ('69) among the Mollusea without any comment whatever, merely giving it the name Solenopus nitidulus. Some years later Tulberg ('75) described what is considered to be the same species under the name Neomenia carinata. This last named author's investigations mark a distinct advance in our knowledge of these forms, since they are concemed not only with the study of the extermal characters but with the intemal organization as well. In certain respects, especially in the treatment of the urogenital system, the work is serionsly at fault, but nevertheless it was thoroughgoing enough to lead Tullherg to conchude that, while the species is vermian in what he considered to be probably the most important characters, it is on the other hand decidedly similar to certain of the Mollusea. 
In 1856 von Graff subjected chaetolerme mithlulum to an examination, which considering the amomt of material and the methods then in vogue, was more than ordinarily searching; and while he, like 'Tullherg, foll into error' regarding the urogenital organs, his results relating to the other systems, repe"ially the nervous, were of the greatest importance. While not entirely conmitted to any particular belief regarding the aninal's relationships he was inclined to uphold Keferstein, Diesing, anel others; and yet he drew attention to the fact that the spicules, gills, mode of egg development, and museulature are so unique that the genus may in reality belong clsewhere, possibly in elose proximity to the Turbellaria owing to the close eorrespondene in the nervous systems.

In 1877 and the following year von Ihering proposed a new classitication of the Mothusea based on extensive anatomical researches largely eoncerned with the nervous system. He drew attention to the very important fact, not previously lecomized, that in many fundamental respects the solenogastres are allied to the Chitons. In his opinion the ancestral neomenian was probably not distantly related to the gephyreans or nemerteans and acoordingly lacked a true shell, and Chitonelhu, with its small sholl and extensive girdle, is thus more closely related to the solenogatsen than of here Chitons and must therefore be looked upon ats a comnecting link. Owing to the presence of lateral nerves the C'hitons, Chitonellus, and the Solenogastres are clearly differentiated from the gephyrean worms and amelids, so that in this and other respeets they approach the molluses. On this aceount a new phylum of Vermes, the Amphinema, was crouted for their reception. The following year ('7S) this same author reviewed the work of Tullberg, Koren and Danielssen, and ron Graff in a suggestive paper, and was more strongly convinced than before that his eonclusions were justified. These pajer's of von Ihering's areated mueh rritirim, some of it decidedly hostile, but it is umbloubtedly true that, while some of the results have not proved to be correct, the work as a whole had a stimmbting effect and has been productive of mucls good.

During this same period ('77) Foren and Daniellsen deseribed a number of speeios collected along the Scandinavian peninsula. In most eases the descriptions are so brief that they are not even of generie value, and the animals remain practically unkuown down to the present day. Nemenia carinata (Solnnims nitidulus) is deseribed at some length, but the facts adduced are not strikingly different from those presented by Tullberg. By these authors the sulnogantres were considered to bo true molhses, and were placed annong the opisthobranchs in a new order, Telobranchiata. 
During this same year lankestur ( 76 ) placed himelf on record to the effeet that members of the genus Neomenia are among the most generalizcel molluses, related to the Chitons and Chitonellus, yet bolonging apant in a phylum which he termed scolecomorpha, the first division of Mollusea encerphata.

Another of the important papers which appeared during this year amor from the hand of ron Ciraff, who investigated the anatomy of Neomenin curmale and resamined chatomermm withelum. From the facts disclosed this anthor was envined that mot only are the two forms constmeted upou the same plan, but that the establishment of the Amphineura as a separate phylum by vou thering was wholly justified. "Wir crkemen in Neomenta und chatotoderma Madificationen einer sehr alten Trform, rom denen die letztere nährer den Würmor, die erstere näher den Molluks'n anknïpft." In ruito a mmarkal)lo way the facts discovered in the study of these two spexies supurented von Ihering's contention that the Solenogastres and the Chitons are allied forms, though they did not foree one to the belief that the Amphineura are neessiarily to be placed in the phylum Vermes, and von Ihering himself abandoned this position a slort time later.

Nout the same time Hamon ('77) published a most important paper on the anatomy of chactederma nilidulum, and in the treatment of all the systems, especially the mogenital, alvaneed our knowledge to a considerable extent berond the old position. For the first time the mode of development of the sex products was determined, and their route traced to the exterior; in other words the broader features of the anatomy of solenogastres now beeame comprehensible. In the opinion of the author, Chatoderma does not elearly belong to any definite place in the existing system of chasifieation; that while certain mollusan characters appear, others are strongly suggestive of annelid relationships, so that its exact position is yet in doubt.

The following year Gegenbaur ('7s) in the "Grundrise" made a few rery" guated statements regarding the relationships of Nenmenia and Chatoderma which may, provicionally at least, be designated the solenogastres and may be regarded as a division of the group Vermes. The ventral groove of Nenmenia "represents the first stage in the formation of that pedal surface of the boly which is seen in the lowest Mollusa." On the other hand the nervous system, while decidedly different from that in the worms, nevertheless pesents some fundamental resemblances.

With the exception of two or three short notices no other papers appeared until ISS1, which in some respeets is the most important year in the history of 
the group. At this time spengel described the imervation of the asphradium,

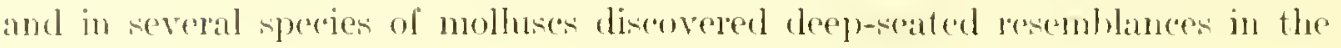
elements of the nervous system and their arrangement. On the basis of this work, which includes the exmmation of Neomenia, Chactoderma, and 1 wo unidentified specius of solenogastres, and with the additional help alforded by the work of 'Tullberg, von Grall', and Hansen he empluatieally claimed, in opposition to von thering and Ciegenbaur, that the Amphinema are true molluses. Aceordingly he established the Amphineura (Chitons and folenogastres) as a class of the Mollusca.

A very short time afterward the masterly work of Hubroht appeared, and in some respects it continues to be the most important work that has ever heen published on the sulject. The study was based ehicfly upon a gigantic species, Proneomenia sluiteri, which oceurs in Barents Soa north of Scandinavia, and embraced a careful examination of its external and internal anatomy. The results, whith a few relatively mimportant exceptions, have been confirmed by the study of many other speries, and form a most substantial foundation for studies of more resent date. Conerening the relationships of Promeomenia, Neomenia, and Chaetoderma the author has no hexitancy in agreeing with spengel that they constitute one order (Aoldnowatres) of the class Amphineurat the Chitons lxelonging to the other (Polyplacophora). In a number of succeeding publications this position is held without modifeation, and the few additional facts of importance that are presented still further emphasize the correctness of the theory.

From this time forth searcely a year has elapsed withent one or nowe papers

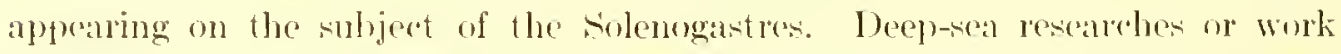
along the shore line beyond the littoral zone have brought to light an ever increasing number of species whose anatomy is now for the nust part fairly well known. Without exception all are built upon essentially the same fundamental plan though in detail cach species presents, as is to be experted, some new and intresting modifications. To the majority of zoölogists the aecumulated results point unmistakably to the tule mollusean nature of these animals, but a glance through some of the succeeding paragraphs will show that there is far from being a unanimity of opinion regarding their position in the phylum and their relation to other groups. The great mass of anatomical details which have been published during the past twenty-five years, serving chiefly to distinguish genera and species, new and interesting though they may be, ean be but briefly eonsidered in a review of this character. 
In 1 ss 2 Kowalersly and Marion called in question the work of all preceding anthors, claming that they in every case had wrongly oriented the animals, that the anterior end is in reality posterior and rice iersa. Tull berg's lateral glands (portion of the coclomoducts) are aceordingly the salivary glands, the penis with its appendages is elearly the radula, the mouth avity is the reetum, the "egg bag" (pericardium) is the intestinal coecum above the pharyx, the loranehia are the buceal cirri and finally the protrusible plarynx is the combined utems and oxidurts.

This paper called forth an immediate rejoinder on the part of Hubreeht, who reviewed the work of the authors in question, and showed that the orientation of the animals in question is correct, and that Kowalessty and Marion have created ronfusion worse confounded whing, for one reason at least, to the fact that they had not seen the species under discussion.

During the next four or five years Kowalevsy and Marion published, eithor separately or conjointly, several papers preliminary to their whef work which appeared in 1887. In this study the authors deseribe to a certain extent the habits of five new speries of these molluses collected alomg the shores of Franee, and acompany it with a very detaled deseription of the extemal and internal antomy. Some of these last named results are referred to elsewhere in the present paper.

In the montimn solenka ('S5) pulblished an arount of the gephyrean worms collexted by II. M. S. Challenger, and therein briefly described Chactoderma militure from the Malay Arehipelago, adding the remark that he was unable to give any data that might settle its systemativ position.

In 1 SSS Ilubrecht deseribed a new genus of solenogastres (Dondersia) taken in the vicinity of Naples. It is a fairly close relative of Proneomenia and Neomenia, and the anatomical characters are acoodingly mot strikingly different from those presented in the paper on $P$. sluitori.

In this same year Hansen ('S8) made a study of several species of solenogastres long before described by Koren and Daniellsen (77). His researches chiefly concern Neomeniu earinata, which is shown more conclusively than before to be similar to P. sluteri. Chactoderma nitidulum was found to pass the sex produets into the pericardium from whence they pass through ducts into the anal eavity (IIubreht) or branchial cavity (Hansen).

l'ruvot (90) denied the existence of a heart, or perifardium or dorsal anta in the solenogastres. The blood moves in lacumae of which a large one passes dorsally along the mid line propelled by contractions of the body. The paired 
genarl, posteriorly becomes single, and opens into what has been termed the periatratium, in reality an acesesoly part of the reproduetive system; while the dorsal simuse courses in a tube (hanging partially in the so-ealled pericardium), which is ealled, by other authors, the heart. In Dondersia benyulensis spermatozoa develop on the external walls of what has been termed the heart, while the lateral wallo of the periondium are ciliated and serve to convey the sperms: as in many hermaphroditic gastropods. Eggs are temporarly stored in the "pnehe aressoire" (pericardium), and the kidneys are in reality genital ducts without ronal function.

In a later paper (90) the sime author describes a few rery interesting stages in the development of Dondersin bamynensis, and two years afterward alds sume further observations regarding the cmlryology of Promemenia aylumpleniae. Ova in the periearlium of other authors) lack membranes; as these are prosent in extruded egge it follows that the supposed kidneys are in reality shell glands. The segmentation stages resemble those of scaphopods and pelecypods, and to some extent this similarity is visible in the later development. I gigantic ('onat of ciliated cells (a highly developed velum probably) is formed, and within this the embryo forms by a process certainly not primitive or at all evonts mulike that of other molluses studied up to the present time. When the volum is thrown off the larra resembles to some extent a young (hiton, posessing severn inhrixated calcareous plates along the dorsal surface and laterally situated flattened syines in what appears to be the girdle. The internal organs at this stage are practically undeveloped, and as the later growth is wholly unknown the present results throw but little light upon the important subjert of the phylogenetic development of the group.

l'okeneer ('90) comsidered (comtra Halneecht and others) that Chitonellus is not a primitive form intermediate between the solenogastres and more typieal Chitons, but on the other hand is highly specislized. These ennelusions were based on data supplied by a study of the brandia, nervous system, and shell. In an introduction to the extensive work of Blumrich (9u) Hatschek seconds Von Ihoring in his attempt to plare the Chitons and the Solenogatres apart from the gastropods, and agrees also with Pelseneer in regard to the position of ('hitonellus.

Owing to the studies noted in the preceding paragraphs the broader features of the anatomy of these animals have bern settled beyond dispute, and consecuently the papers from this time forward serve in large measure to supply dretails, and to a limited extent indirate the phylogenetir relationships of this 
group of animals. The more special features relating intimately to the various systems are noted to some extent in the main body of the present paper, white the general eonsiderations are disensiced on p. 164-173. Anong the more extensive of these works are those of Pruvot (91), who has deseribed several sporises from the shores of France; Wiren (92) whose study of several species from the Scandinavian coast is among the best that has erer appeared; Finmoth ("93) and Pilshy (as) whose systematic works are of the highest value; Thiele whose various papers during the past fifteen years have added naterially to our knowledge of the anatomy of molluses, including sereral species of solenogastres;

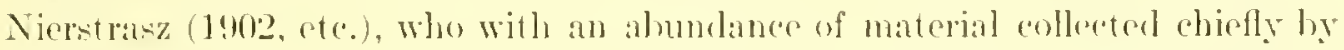
the silmea Expedition, has added extemively to our information of these aninuls; and finally the present writer whu has contributed some data relating especially to the nervous system.

Since the above was writen Niestras has published an important report (190s) reviewing the work of rarious investigators since the appearance of simroth's paper in 1893 . It is a valuals] contribution, and the scheme of claswilication there adoptext will be of much service.

Turning now to the broader features of the chasifieation of these animals we find that practically every investigator in this field of researeh is agreed with spengel that among the Mollusea their nearest relatives are the Chitons: but regarding their more accurate position within the phylum differenees of opinion appear. Von thering in 1877 alled attention to the fact that the solenogastres and the Chitons are not distantly related, espeetally if we consider Chitonellus to he a connecting link and therefore a prinditive animal. Acourding to this line of reasoning the solenogastres, deroid of a radula (nome had been discovered at that time) and shell, are the more ancestral and are so elosely related to the worms that both they and the (hitons constitute al sperial plytum (Amphinenra) of Vomes as noted in a previous paragraph. Hubrecht, withont laying much stress on the ancestry of the Imphinenra, though he hints at their derivation from a platyhelninth ancestor, was likewise of the opinion that the solenogastres are primitive, and that Chitonellus is a link connecting them with the more highly modified Chitons. It may be mentioned also that Haller in 94 modified some of his previous ideas, having beene convined of the correctness of ron Thering's and Hubrecht's position.

The above idea was combated hy Pelseneer (90) who rlamed that Chitonellus is nothing more than a highly modified (hiton and in no direct way related to the modified group of the solenogastres. Hatwhek (91) agreed with this 
theory though he did elaim with ron thering (a theory abandoned by him in 90) that the Amphinenare Vermes. Crobben (94) likewise considered this the correct view though he believed the Amphineura to be tme molluses. This unotion is impliod in the work of Haller ('S2), who made the elaim that the Chitons and the solenogastres are distinct groups of ammals which have been dejived from a common vermian ancestor. In a more vigorons fashion Thiele argues from the same standpoint.

With one or two execptions those who argue along the line just indieated regard the Solenogastres as primitive animals, and are arcordingly opposed to several investigators who hold a diametrieally opposite viow. Simroth, Wiren, and Heath believe that the Solenogastres early branched off from some primitive polyplacophore and while retaining several primitive features are in other respects degraded organi-ms. Pelsencer and Carstang take practioally the same view. Marion, in a sense, does the same as he compares the adult folenogastre to the larra of the Chiton. Plate traces the solenogastres and (hiton lines of descent to some ancestral molluse which may have given rise also to the present classes.

In regard to the derivation of the molluses, and the Solenogastres especially, from some premollusan ancestor there are a mumber of widely divergent theorjes. In 1877 von Ibering believed that among the worns the gephyleans are most closely related to the solemogastres. Haller ('S2) on the other hand regarded them as more closely allied with the nemerteans. Hubrecht, Thiele, Plate, and a number of other witers consider that the molluses, or at all events the Solenogastres, arose from a turbellarian-like ancestor. This idea has been most fully developed by Thiele. Areouling to him the progenitor of the molluses and the Solenogastres (which ane romidered to be worms) was in the fundanental characters of its organization similay to the modern cotylean polyclad. The often frilled sensory margin of the body became the mantle, which for purposes of protection, developed a cuticular covering and ultinately a shell, while the ventral surking disce expanded into the mollusean foot which in its least nodified form oceurs in Halintis and similar speces. 
GENER.I, FEATURES, METHODS, ETC.

Extennal. Characters. - The Solenogastres eonstitute a group of marine animals, which combine with features more primitive than in any other molluses mumerous others indienting a high degree of modification. All are bilaterally symmetrieal, worm-like in form, nsually nearly round in cross seetion, and vary in shape from short thick set to very slender greatly elongated types. While the average length is not far from twenty-five millimeters several species such as Notomenia clavigera and Kruppomenia minima are from one to four or five millimeters long, and on the other hand Proneomenia sluiteri reaches the giant size of one hundred and forty-eight millimeters.

The mouth, or more moperly the atrial opening, usually in the form of an elongated slit, holds an antero-rentral position, and is clearly separated from a ventral median furrow, in the Neomenina extending throughout the entire length of the body. This latter structure is generally considered to be a true pedal groove, the small fold included therein and abundantly provided with glands being the foot. In the Chactodermatina no external trace of these organs exists, but a gap in the ventral musculature, and a thickening of the muscle bands on each side of the mid line, and in Limifossor a definite pedal simus, indicate that they were present at a former time. In what must be considered a primitive condition the ventral furrow in posteriorly continuous with what has usually been termed the cloacal cavity, which contains the openings of the urinogenital apparatus, anus, and the respiratory organs. As is more fully shown in a succeding paragraph, the cloaca is in reality a mantle cavity, and the two branchiae it contains in the Chactodermatidae are umdoubtedly true ctenidia. On the other hand the folds of the cloacal wall, sometines exressively developed and highly vascular, do not appear to be rudimentary nor degenerate cteniclia.

$\lambda$ cuticular sheath, often of great thickness, envelops the body, and contains from one to seven or eight layers of ealcareous spicules. Where more than one layer is present groups of cells constitute papillate or organs of problematical use. In the adult eondition all traces of a shell are absent, but in the development of Myzomenia (Dondersin) banyulensis, as determined by Pruvot, a stage oceurs in which the embryo bears on its dorsal surface seven slightly imbricating, calcareous plates.

InTERNal, ANATOMY. - In regard to the internal organization there are numerous features that indicate a degraded condition, due probably to parasitic 
halbits or an adiaptation for a life in the bottom ooze. In Chaetoderma the alimentary tract is a comparatively simple tube pasing directly through the borly, (as with other solenogastres), provided with a radula, reduced to a single median tooth, and a roluminous milober liver. In other genera (Prochactoderma, Limifossor) of the family the radula is of large size, and is typically formed and plared. In the Neomeniina this systrm is more complex. The first division of the digestive tract, which may be termed the atrimm, probably corresponds to a highly modified buceal plate, and though usually comected with the mouth (Diagram P. 20, A) may be separated from it. The walls are modified into
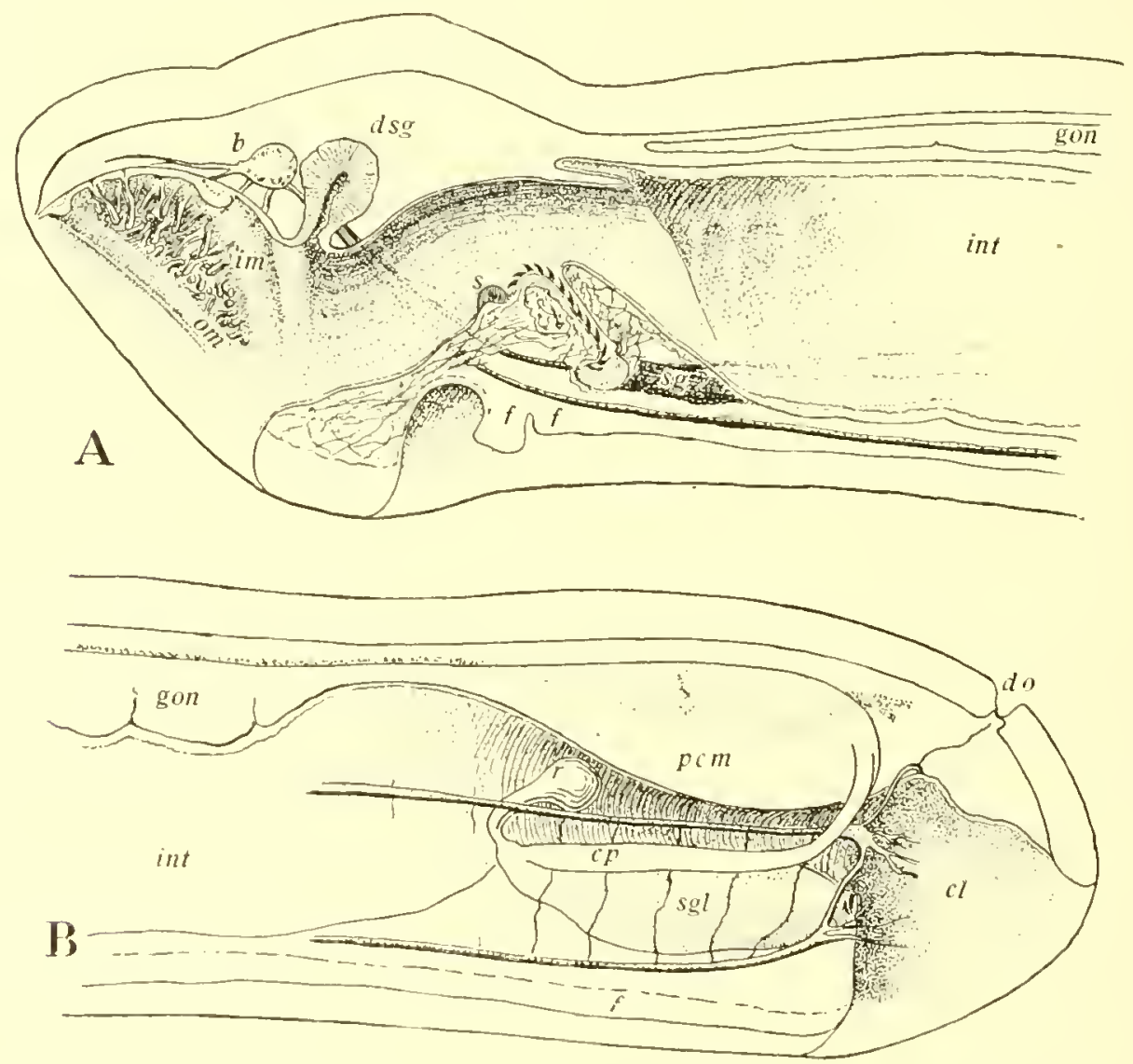

Diaurane illustrating struclure of a momenian. A anterior end. b brain; dog dorsal salivary glanl; f font; gon gonal; im, om inner and outer atrial ridges enelosing the cirrose areat; int stomacliintestine; s subralular organ; serentral salivary gland. 13 postorior end. A cloacal cavity; cp dorsal limb of gonouluet; do dorso-terminal sensp organ; pem pericardiun; r seminal receptacle; sgl ventral limb of gonouluet or shell gland.

ridges and cirri, mobably sensory struetures. A radula is generally present thomgh often greatly peduced in size. In addition to the dorsal salivary glands, probably existing in certain Chaetodermatina ar well, a ventral pair is usually 
attached neas the radula. I definite digestive gland is wanting, the mid-gut pouches being lined with hepatie eells.

Owing to the great reduction of the foot and correlated changes, soveral peculiarities appear in eomection with the cirrulatory system. Is in the Chitons the beart is posterior, and the anda passes along the mid line domal

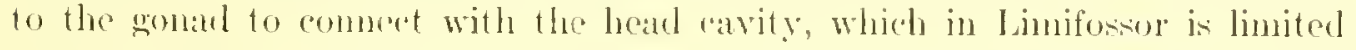
posteriorly by a well-devoloped septum. In this genus there are indieations also of a pedal sinus, fut behind the head region it largely disappears, the blood flowing between the gut and body watl to the branchial region. Pasing through the ctendiat, or the folds in the closeal wall, when these ane present, the blood makes its way to the posterior end of the heart.

The nerous system bears a striking resemblance to that of the chitons. There jo a greater concentration of the nerve eells to form well-differentiated ganglia, but otherwise there are, in such species as Pronemeniu hawaicnsis, no. especially unirque foutures. The supranesophageal mass originates throe pairs of nerves. Which innervate the huceal and nejghboring lwely walls and three pairs of enmectives, the labiobuecal, pedal, and lateral. The first named, in at trpioal condition, is decidedly ('hiton-like both as regards its position and elements. The other two, passing hackward throughout the entire length of the animal, are united frepuently by commissures and comnotives, and nay

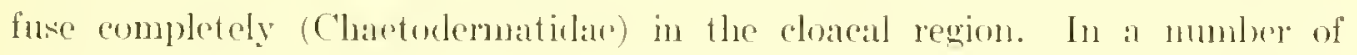
other species the pedal cords, after dinninishing in size in the hinder regions of the body, may lack any comnection with the latedal gandia, or they may terminate in ganglionice enlargonents (gonglion posterius inforius of Wiren) united ly connectives with similar swellinge (gang. post. superius) on the end of the lateral cords. The latter gangliat ane invariably united by a heary commisome passing dorsal to the rectum, and the pedal colds likewise may be conneded by a subrectal commisure, thus completing a circumredal nerve ring.

In the solenogantres the secondary body ravity romproses that of the gonad, periearlium, and the duets leading from this latter spare to the rloata.

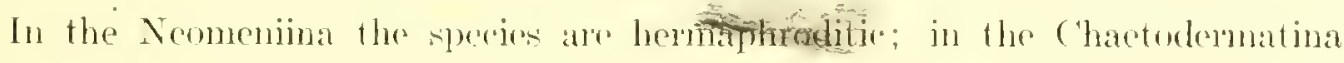
dioccious. The sexual elements pass though the perioudial cavity inte the coelomoducts, which in an immature condition atre relatively smple, and in some species at least are not fused leefore they open into the eloacal cavity, characters which the Chactodermatima retain throughout life. In the Neomenima, on the other hand, various modifieations may oceur which produce a high degree of complexity. Two or more seminal receptacles are usually present, 
and the walls of the median undivided reetion and a portion of the canals leading on to the pericardium bexome greatly thiekened to form the shell gland. Whether these camak ever function as kidneys is an unsettled question. In the Chatodermatidae there are indications that they do, but at the present time there is no experimental aridence in support of such a view.

Our knowledge of the development of this group of animals is very ineomplete. From Pruvot's Work on Myzomenia banyulensis, and ny own on Halomenia, it is evident that the carly history resembles that of certain famellibranchs and the seaphopods. Pruvot's interesting dicovery of a stage where the emblyo bears seven ealearous shell plates indieates, as a number of authors maintain, that the Aplacophora have descended from polyplacophorous ancestors.

Methods. - On several occasions I have tried the effects of various killing fluids, and am convinced that for general histological work aleohol is the most satisfactory and is easily eontrolled. Specimens from deep water are usually in a moribund eondition when they come up in the dredge, and undergo praetically no contraction when plungerd directly into $70 \%$ aleohol. Where the animals are more hardy or have been taken in comparatively shallow water it is advisable to add gradually ahloretone (aceter-chloroform) discolved in alcohol unt il they are completely nareotized. They may then be placed in 70 \% alcohol for a few lowe and preserved permanently in an sor solution. In wam weather it is sometimes nersisury to krep the specimens in a rool place until thoroughly fixed, and in any case it is necossaly to use considerable puantities of alcohol. In the study of the nervous system 1 have found rom Rath's fluid highly satisfactory especially when the material is treated suberpuently with a $1 \%$ solution of pyoligneons acid. When sufliently oxidized the nerve fibres remain grayish in color and are usually guite distinct among the yollow musele and connective-tisue fibres. For staining 1 have generally used Delafield's haematoxylin, rarely using rubin as a secondary stain.

In connection with certain features of the nervous system the specimens used were of sufficient size to allow of dissection. Under such eireumstances paraffine was poured into a small dissecting pan and while it remained soft the molluse was partially imbeded in it, thus obviating the use of pins. Dissection was done under alcohol by means of a needle mounted on the end of the arm of an instrument for mounting diatoms.

In removing the euticle from about the spicules can de Jarlle in preferable to eaustic potash which frequently exerts a decided corrosive action on the more delicate spines. 
Ocourance. - Owing to the methods cmployed the solenogastres deseribed by the catlier atuthors, and a small fraction of those subseduently discovered, have been taken in compatratively shallow water, in a rery few cases within the lifforal zone. Howerer it camnol bo sald that they are eswentially shore forms, for the various deep-rea explorations of recent reats hase demonsmated that, in certain lowalities at least, they are a characteristic feature of the deeper regions of the sea and only exeeptionally extend into habitats along shore.

With the publication of the present paper the number of species of solenogastres reaches a total of nincty-two. In most instances these have been described from ane or at most a very few specimens, but the scantiness of material appears to be the combined result of habitat and mode of capture. As mentioncd in a sucreeding paragraph, these animals are either attached to some coelenterate host or they burrow in the bothom ooze. In the lirst ase they may be readily disfodged and lost; in the second they are usually ont of reach. On several occasions, while acting as temporay natumbt on the U. S. F. C. Str. "Albatross," I have beren alyle lo examine carefully large quantities of mud, which has been scooped from the bottom, and have secured munually lange numbers of individuals of a fow species. In Naska (Sta. 4264), for example, the dredge load contained forly-seven sperimens belonging to wo different gencra (Limifnssor talpoideus and chactoterma emedita). Again in Monterey Bay, California, one haul (Nta. 4522) contained fifty-nine ('haetuderma montereychsis, whike in a neighboring locality (sta. 4523-4525) eighty were taken. In the Nafional Muxam I reently examined a large number of small animals taken by the "Allathose" in the Atlantic, and discovered no hess than thirty specimens of these molluses belonging to fwo genera. From such dat a and considering that the anome of territory explored is but a tithe of the entire sea floor, it is reasonable to suppose that in point of numbers and of speeies these animals will far surpass their nearest allies, the Chitons.

Owing to the fact that up to the present lime no Solenogastres have been repolted frum the North Pacilic, and since the speries described in the present paper have waully been collected from widely separated slations in a single dredge haml, it follows that there is liffle to be said definitely regarding their general distribution. It is an interesting fact that of the eight species taken in Japan six belong to the genus strophomenia. The genus Limifosor is represented by two species off Alakk and California respectively. This last named region is likewise the home of Alexamdromenia agassizi and 1 , valide. species of Chaetoderma occur in the ooze in all of the carefully explored terri- 
tory mentioned in the introduction. Howerer, it cannot be said that in any eate we have any very definite information regarding the geographical limits or relative abundance of a single species.

There is little to be said reganding the vertical distritution of the species described in the present paper. Where several individuats have been seemed

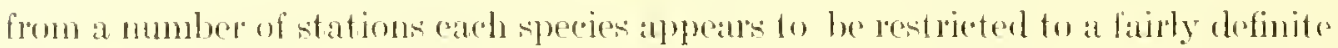
depth. Clonetodermen nilidulum in reported to have at range of from 14-1250

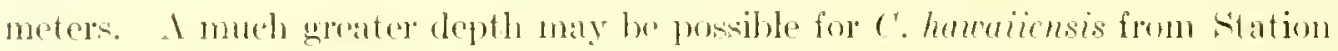
4130 where the initial sounding renerded 1362 fons.; but sinces the desing rounding was 358 fms. it is probahle that the latter figure in more nearly correct, as a second specimen was taken at a depth of 528 lathoms (Nta. 3992). In many plares the orean lloor is exeerlingly rough and chanacterizod by high almest vertical eliffs bounding firsure-like valleys. Uneler such cireumstances a num-

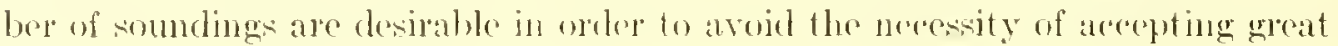
extromes in vertical distribution though these may in reality exist with restain species.

Mone of Lre, Food. - The speries belonging to the Chactodematidae are, sis far as known, inhahitants of the sea buttom where they excavate burows which they rarely leave. Wiren (92) who kept over one hundred specimens of ('. nitidulum in captivity sily, they progress through the ane by means of the alternate antratetion and cxpansion of the prothorax aided by movements of the entire borly; and that when at rest they ordinarib direet the borly vertieally with the cloaldal chamber widely expanded, and the branchiate fully expored at the opening of the burme at the surface. When disturbed they disalppear instantly sereral inches into the murl. In must respects these observations answer for (". cruditn which I kept some time in captivity. This animal frem time to time advanesl through the ooze in the mannel described by Wiren but it never appeared at the surfaces. For home togethere it remained curetly in its hurrow with the gills fully expanded and when disturbod retreated but showy,

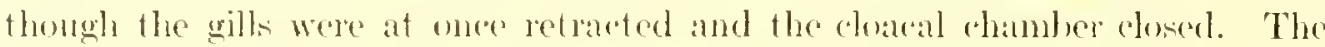
inclividuals acting in this manner were apparently in a nomal condition since the alimentary canal of several kent in captivity for nearly one month contained quantities of food.

The members of the sulnerder Nemeniina, on the other hand, are not known to burow, but are usually found on some species of hydroid, coral, and exceptionally (Promeomenin menes, P. desiderata), on plants. Now and then specmens have been dredged matlached and it may be that they, like Ncomenia 


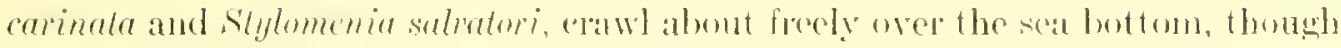

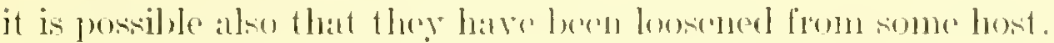

The relation of molluse and coelenterate has not beres thenoughly worked out, but there are many indieations and some clefinite prosel that it is a genuine

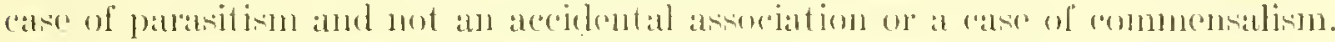

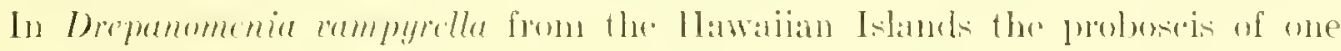
individual was inserted into the body wall of some specios of lipizonthus, many of whose reprodhetive and othere cells had been withdrawn so that here there is

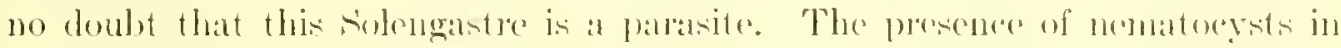
the alimentary canal of reveral other species, ineluding most of the spredes of

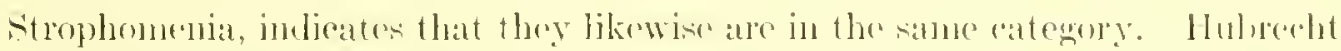

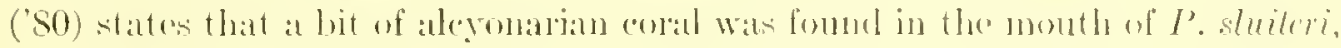
but he calls attention also to the latet that diatoms and contomostracans onedred

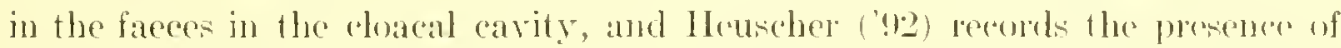
Entomostran in the gut itself. It thes develops that the diet of smehs speries

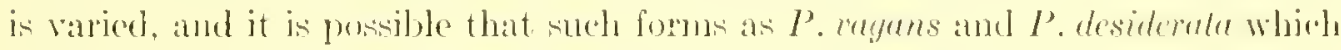
were found crawling alonut on plants belong to this same elass.

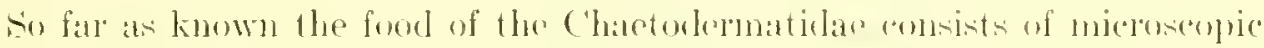

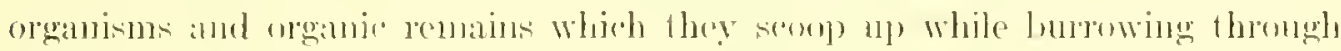
the ooze. Wiren (12) beljeves that the bureal plate (Mundschild) alets ats a

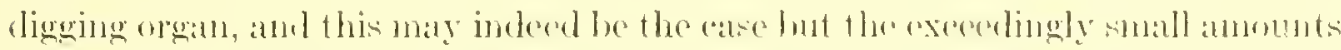
of inorganie material, wheh make their way inte the digestive trated, indiente that in arklition to lunetioning in at purely mentanieal lashiom it matniferts a

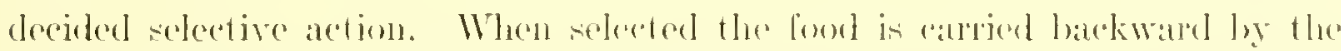

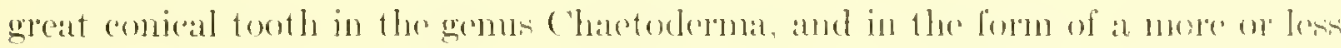

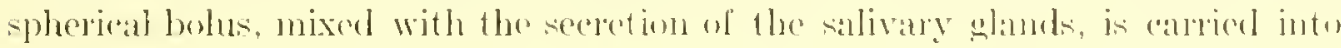

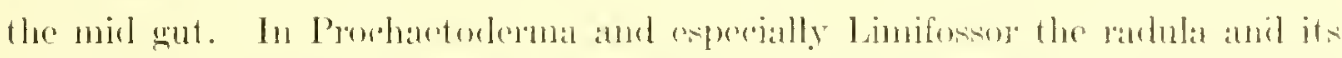

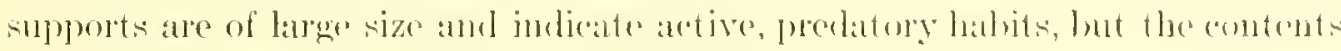
of the gut are ciscut ially the same as in chatetodermal.

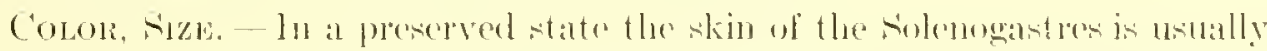
unpignented, the light yollow or yollowish hown tint of the aninat leeing due to

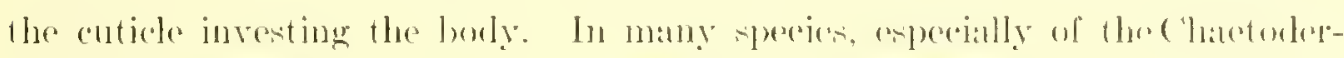

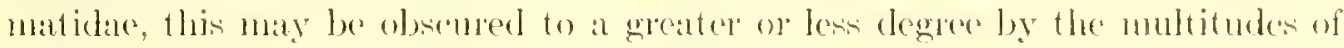

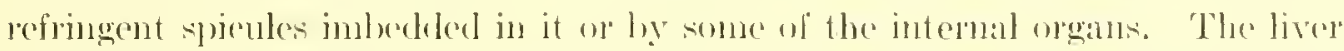
for example is often dark lowwn, and shining through the translucent body wall and the overlying euticle and -pobules, gives a deaded frosted gray tint to several species. The red color of the blood platsma may inpart a pinkish linge enpe- 
cially in the head and cloacal regions. An incrustation, rusty red or hack, may cover the entire animal though it is ustally mestrieded to the posterion extremity. In a very few species some of the hypodemal cells contain pigment,

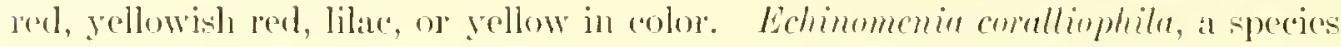
living on Corallium rubrum, is provided with movalule scales which when depressed give the body a whitish dint resembling the tentacles of the host, and this may possibly be the atse with strophomenin spinoso. Upon raing the spines the pignented hypolemis becomes less obscured and the animal assmmes a rechlish color similar to the eoral stalk.

The mallest sexually mature folenogastres are not over 5 mun. long, and on the other hand Pronemeniu sluteri attains, as previously stated, the great length of $148 \mathrm{~mm}$. The average length is probally not far from $30 \mathrm{~mm}$.

Lengtn INDEx. - In the diserimination of species the so-called length index, on the ratio of length to breatth of borly, has been used to a considerable extent, but from several experiments in the preservation of fresh naterial, I an convined that it is of little use, certainly mot with alosely related forms. For example nearly sixty Chatonterma montereyensis, which hat come up in the same dredge haul, were treated with show aloohol in procisely the same fashom and

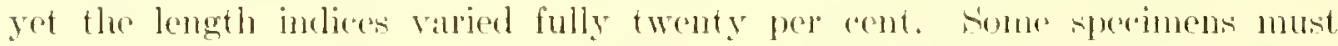
invariably be subjected to a greater presine than others in the dredge loald, and these are more flaced and less contratile and with them the length index is relatively greater.

\section{COMPARATIVE ANATOMY.}

Fout and Glands. - It is now a generally aceppted fact that the ventral furrow and its inchuded fold represents a greatly redued predal fumow and fort. In the chaetorlermatina all extenal traes of these structures have disappored completely, but intemally a gap in the ventral musendatum and a thickening of the longitudinal musedes on eatch side of the mid ventral line and in Linifoseser a well-developed pedal sinus in the hearl region indiente their former existence. In what appears to be the least modified species, the foot consists of at simele fold, but in several other species this is accompanicd on each side by at fold of almost equal height and length, and in the Ncomeniidac the creeping surface is often comparatively broad and is developed into several folds. Whether. one or more of these plaits exist ach is bounded by a single layer of ciliated 
epithelinm which as a rule is antimons with the lining of the cloarat. The last named space is ertainly at true mantle cavity and the plume-like branchia it contains in the Chaetodematidae are ctenidia. On the other hand it is questionahle il the folds developed in the cloateal walls, at in Mlexandromeniat for example, are homologons organs.

Is in the (hiton embryo two sets of pedal glands exist, temed ly Hubrecht ('so) the anterior and posterior pedal. Thr firs named is a highly doveloped organ filling the greater part of the space between the body wall and gut in the head region. It is eomposed of pyriform cells whose ductules leand inte the anterior end of the pedal furrow, which is usually developed into a ravity of considerable size, where they make their exit hy separate interenlubur openings. The posterior pedal gland is situated abow and stightly to each side of the foot throughont its entire extent. Its alls are likewise pear shaped and open intercellularly into the petal furrow.

Hypodemus and Prodets. - What is sometimes temed the slim consists

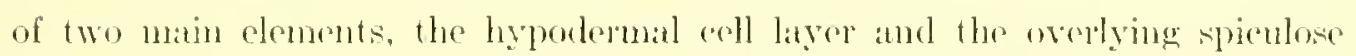
cuticle. In the majority of species the lypoldomis consists of a single layou of cells, and exreptionally (Poramonin paliforn. Ichlhymmenia ichthyodes, for example) forming a more or losire irregular many coll layer. Comeroning the mature of the elenests entering into its formation there are numerous differences judging from the arenunts of the varions authors, and the functions ascribed to them are extually diverse. The ordinary hypodernal cells, those responsible for the formation of the cuticle, are numally cubical or low columnar in form with round or oval muclei inbolded in a limely gramular cytoplasm pignented in a few species (e.g. ('. mitiduhum) which blends with the overtying cutiele. In the same general situation gland cells are present in several species together with more slender olsulents whinh may perform a sensory function.

The papillace oceur in all Nemmeninat in which there is more than one layer of spicules inbedded in the cuticle. Cienerally speaking earch eonsists of at comparatively slender statk which is attached to the lypodermis, and on the other hand expomels into a more or lrus globular mass in contact witl the free surface of the cuticle or may even project above it. The cells composing the swollen portion are appatently filled in life with a highly spongy, posibly vacuolated protoplatsm which in preserved material may shink greatly, producing radiating pseudopodia-like processes. In IIalomenia gravida outpouchings of the gut oecur at fairly regular intervals along the dorsal side of the animal on each side of the mid line. These penetrate the somatic musculature (Plate 32, 
tig. 5) and come in contact wilh the under surface of modificel papillate, which appear to be capathe of a certain amount of protrusion owing to the agency of a surrounding blond sinus. The signifientere of this remarkable state of atfairs

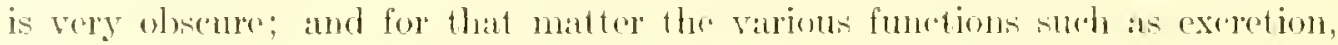
touch, and pressure relations whidh have been aredibed to these orgatns ats yot rest upon no direct experimental evidenes. That they are the lomelogue of the acsthetes in the Chiton shell is a reasmable assumption, lut this carres with it no trustworthy evidence regarding their office.

The spines form from one to several bayers in the cuticle, and present a great variety of forms. In the chactodermatima spearhead-types preval, and in the Neomenima, where there is but one layer, this shape may likewise oceur. In those speries with more than one layer the wast type is needle-shape, and with it may be asociated radially direeted spienles nenally with truneated bases.

Sircule Developaent. - In a number of speeies of the present collection,

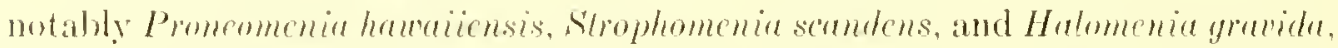
eretain of the more important aldails of the formation of the spiculese inventment of the body alpear with unusual distinctuess, and 10 avoid needless repetition the results are discusced one for all in the following paragraph.s. Speraking first of Proneomeniu hementensis, in the carliest stages of the spicule formation, where the ealcareous product is mo barger than the neighboring hypodermal eloments, several eells are seen to be taking part. One of somewhat latrger size than the others, and with wear finely vacnolated eytoplasm and distinct granular spherieal nucleus, rests underneath the batse of the spine. Its eneneral appeanance is essentially like that of the and beneat th the spicules of $r^{\prime}$. nitidulum at figured loy Wiren or the spicule forming ants in the mantle of certain species of chitoms,

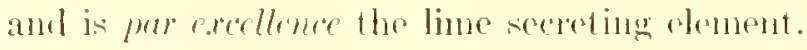

Wiren is of the opunion that the batal acell is a medified wandering eetl that hat loft the blood strean and migrated to the hypodermis. In all of the soleno-

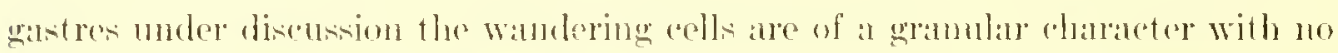
distinet eell nemblane and clearty different from any of the hypodernat eells. Furthermore in the species under discistion l have never seen these plasma aells wutside of the somatic musele layer, and there are never any indications that the spirule forming elements are derived fon any other soure than lhe hypolermis.

In very early stages, perhaps from the lirst, the spicule is surrounded by a delicate cuticular sheath whose reaction to the ordinary stains indicates at composition unlike the material in which the spicules are imbedded. This spieule 
sheath is probably formed by seven or cight aells, slender in form, indistinut in outline, with dense nurele and atlombated bases which ase imberded in thes hypodermis proper. They entirely smromel the losal coll, and distally their membranes locome continuous with the spicule sheath, which as Plato 36, fig. 5, shows, is thus intermpted a short distance above the base of the spines.

At a relatively anty state in the development of the spine a minute reell (Plite 36, fig. 11) may be detected betwers the hasal coll proper and the spicule sheath. It first it appears to be comnered with the deeper portions of the hypodermis by a single stalk that passes to one side of tho basal cell; but in later stages such a connection disappears and the cell in question becomes colosely applied to the base of the spine. It appoars to be responsible for the formation of the spicule sheath immeliately above it and in the following way for the eavity of the spieule jtivelf. At first the cuticle above this small basal sheath eell is of uniform thickness and the lime salts, deposited presumably by the basal eell proper completely fit the spieule wheath, but very soon a minute knob-like elevation appears on the basal part of the sheath, and, perhaps owing to this increased thickness of the cuticle, it intrefres with the deposition of calcarens material, for from this time on a ravity develops in the spine that in size and position enresponds to the cuticular knob. As the latter inereases in size the spirule cavity enlarges, and when in later stages there is a decrease the eavity becomes proportionately narowed until both finally disappear together.

In the earliest stages of its existence the long axis of the spine is at jight angles to thr hypolemis, but as development progresses it beemes more and more inclines until it reaches the funal horizontal postion. This rotation is probably due in large measure to the mecpual elongation of the at tached cells, while the continual advanoe of the fres tip of the spine through the surrounding "uticle is due to the addition of new material basally. During this whole formative period and after its completion the entire spicule is migrating also toward the fre surface of the hody. Hubrecht and several other subsequent observers consider that this morement is caused by the entinual cuticular anrent, so 10 speak, brought alwut hy the perpetual addition of new material in contact with the hypolesmis, a belief with which I concur for on any other supposit ion it would be difficult to acount for the perfectly vertieal, unbent position of the sender remuant of the matrix reels in late stages.

Until the spine has been carried outward for a distance equal to one fourth or one third the thicknoss of the cutide the matrix cells retain their usual eonneetions and generally are farly distinct though showing more or less shrinkage 
(see Plate 36). This latter feature becomes strongly marked beyond this stage and as the cells shift to a distinetly subterminal position their boundaries disappear, and in the neighborhood of the spine they become dense and fibrons. still later they migrate to a point fully one eighth the length of the spicule from ateminal position, their attachment to the spicule sheath becomes redueed to a nimute knob-like dise and all but the basal portions of the wells themselves become transformed into a slender fibrous stalk, which elongating as additions are made to the cuticulas investment of the body, mantains its attachment with the spine as long as the latter remains in the euticle. In the region of the hypodermis the ontlines of the matrix edls remain distinct and mmodified with the exerption of the enclosed basal cell which becomes distinctly fibrous. In rertain slightly abnomal cases the stalk is sometimes musually broad and moler such eireumstances the hasal aoll in hater stages becomes distinctly fibrillar throughout its entire length, while the smrounding ensheathing rells assume rather a cuticular appearance and never so far as l have seen assume a fibrous character. In a very considerable number of cises the fibres, of muknown nature, that have dereloped in the original hasal cell may be seen to extend benath the level of the hyporlemis, or to unite with others that may be traced for varying distances into the smontiv numcles beneath. In the region of the buecal eavity, in Proneomenin humaiensis, they may bo followed thromed spaces in the mucle layes into close proxinity to the ganglionic masses bordering on the eirri. So long as the spicule remains imbeded in the cuticlo the stalk is in commection with it, and appeallaneses suggest that after the basal cell ceases to be functional as a spieule forming agent it may transmit impulses to the central nervoms system as the spines and sales in the matnte of the chitons are supposided to do.

In IIatomenia, Lephomenia, Dorymenia and all of the speries of Strophomenia described in the mesent paper this trpe of development prevals. In some speries the matrix colls berome detached from the fully formed spine, but utherwise no fumdamental differeners exist. Regarding the species described ly othere anthors, Hubrecht and Hellocher ander that in Proneomenin shiteri a "up of sereral cells claps the lase of the spicule, and howalersky and Marion and to a rertain extent Pruvot, and Wiren have nade sinilar observations on other species. Through the generwity of Profesor Hubrecht I have been able (1) examine a portion of the type of $P$. sluteri and though the cells are not so reanly defmed as in P. havaiunsis there is no doubt that in both the spines follow the same course of development. Nierstrasz writes of Cyclomenia holo- 
serien "The spieula remain in connew ion with the hypodemis by thin threats, met with evergwhere in the spiculal" ("uticula?) and of $P$. diseneryi he states that "The spienles are formed in small atermunlations in the cpidermis" though one eell only is said to be alutive.

Thiele has consistently argued in favor of one matrix cell and it is probable that he has focused lis attention on the tyo of spone I am about to describe.

As noted in a preceding paragraph, there are in addition to the tangentially placed spicules in some spereies others that from the begimning to the elose of their development are dirested badially. This latter type of spine, so far as I have detemined, hat a mode of development ampletely different from the one just described. In Strophomenin tringuluris for examplo as soon as it becomes

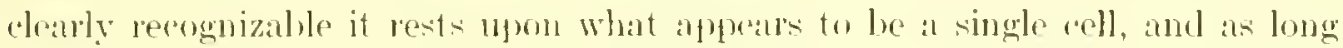
as it romains in the cuticle no adelitional clements put in an appostrance. In the later stages the matrix cell uslatly beomes mole cup-like olosely alasping the base or side of the spine (Plate 36, fig. 1S), and it may alongate to form a slender stalk lut it is always monicellular. It is to be noted, however, that in this speries, and perhaps in others, there are additional, rarlially slirected spines of much larger size which appear to be formed by more than one cell though this is not certain owing to the faret that the base of each spicule is crowded against the somatir musculature.

In the Chaetodomatidar Wiren has shown that hut one formative cell exists though in its eaty stages the spine is surrounded by three hypoulemmal redls which may exereire a moulding influence. From nuy studies I doubt this last statement. In both chatoderma and himifossen the formative redl is sumroumded by hypodermal coments but there is no evidence that in the devolopment of the spine they take any aroive part. It thus beromes evident that there are rarons trpes of spicule formation among the solongatres just as there are among the ('hitoms, but it is a most interesting and signifirant fact that the most common type of Chiton-spine development according to Plate, '01, Theil c, p. 372) is alnost the precise comnterpart of what exists in $P$. hawaiensis and several other species.

Wiren is inclined to the belief that after the spioule forming edls have performed their function they become transformed into the hypotermal papillate. There is confessedly no detinite evidence to substantiate surh a theory, and on the other hasd there are one or two farts that temel to cliseredit it. In the first plase there is no definite relation between the number of papilae and spines: in the majority of species the latter eonsiderably outnumber the former, notably 
in Mexandromenta. And again where the spiente retalus its anmedion with the original formative edls sueh a fate is out of the ruestion. And finally a few

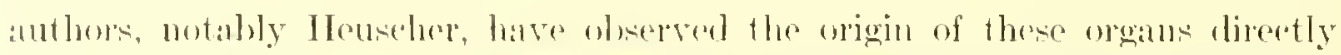
from the hypodermis. I have seen many times papillac-like elerations (Plate 36 ,

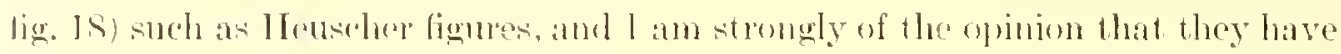
no conmedion with the matrix aells.

Dreastre Tract. - The anterion division of the alimentaly eanal ronsists of a "avity whose walls are provided with two folde (Mundleisten), usually of

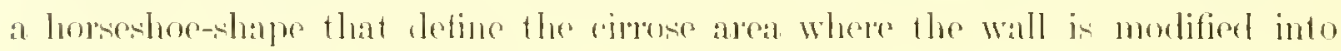

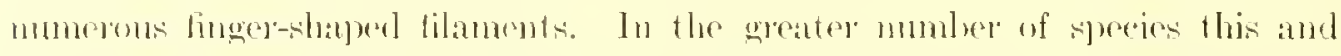
the sureeding putions of the gut are intinately mited, hut in Rhop. agleophenier, Dondersia, and a fow other speodes they are clistinetly sepallated by a

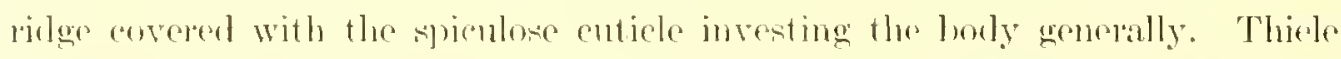
considel's that this sensory atrim is an ectedeme insagination of the integu-

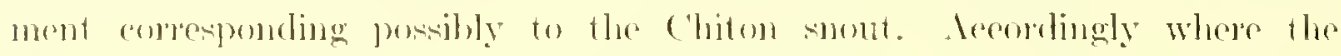

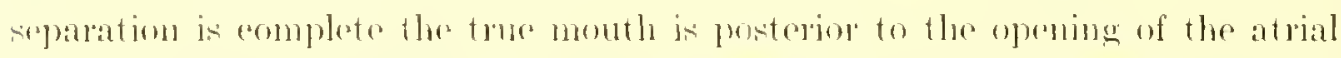
"avity, and where the latter is fused with the gut flue month is situatcel behinet

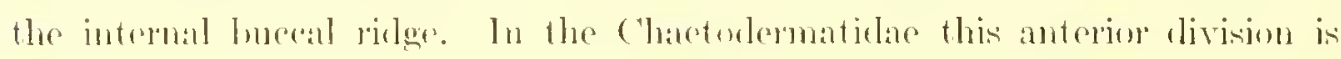
absent on is representod, as Thele aswmes, by the buenal sensory plate and

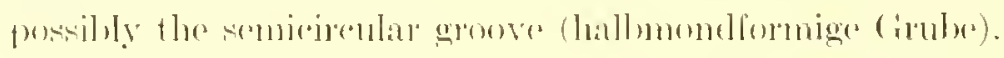

The limits of the phargnx are elifficult to define but it is gemerally assumed

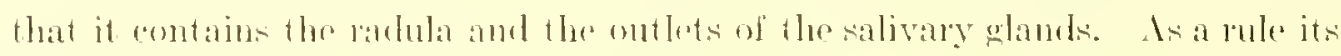

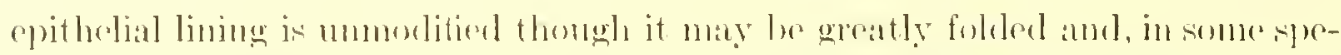
eire form papillare, which afford an ontlet for the thoral walivary glamels. If an

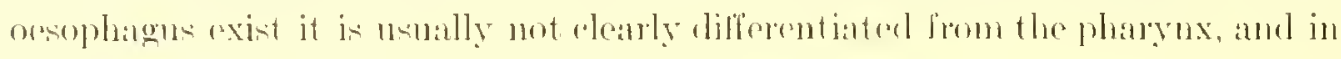
the following pages I latre dioregardorl it.

lu the Nommibut the digestive gland on "liver" is not differentiated from

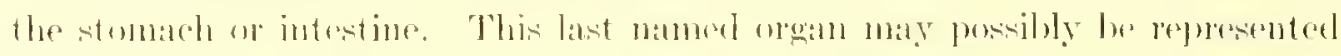

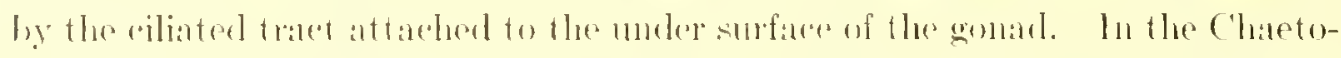

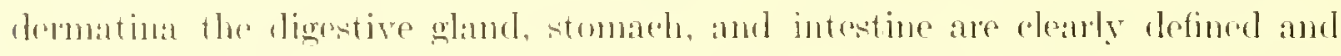
are met exsentially therent from what exists in other molluses. The cloaral

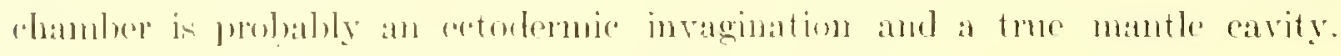

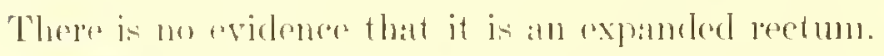

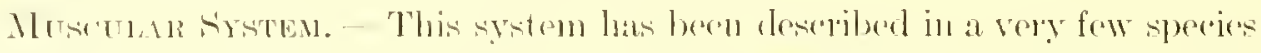
thomgh mest anthore refer to the more obvious features especially the nature

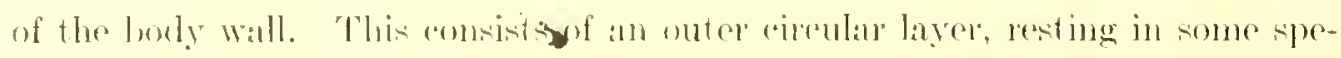

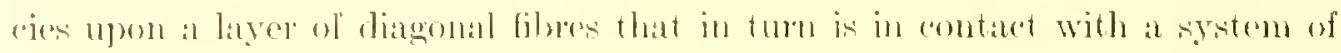


longitudinal bundles. In the antorior and posterior regions these are subject to varions modifications, forming mouth and cloacal sphineters and dilators, and affording attachment for the gill retractors or anteriorly for the muttitudinous muscles operating the forwad sertion of the digestive tract. These last named museles have never heen fully studied in any species though they are fairly wedl known in Chactodermu nititulum and Limifossor tulpoideus. Is the matter rests at present there is a simbianty between the varions species with respect to the somatic musculature and to ecotain of the more conspiemous bundles dsewhere in the body, but beyond this our data are too insuffieient to permit of close comparisoms.

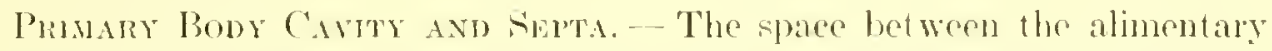
canal, gonad, and body wall, the prinaly body eavity, reaches a varying height of development areording to the species. In the Chactodermatina it constitutes al (omparativoly limited pseudovascular system and in some of the Nomenina it is likewise much reduced, but in several species it beromes much more extensive. This hamocele is divided by a horizontal septum that extends between the longitudinal fibres on each side of the body beneath the grut and so forms a ventral hood sinus. In the Neomeniina it is small, hut is bounded, in every species drerribed in the present paper, by commective-tissue fibres perforated here and there to permit of communieation with the orerlying blond

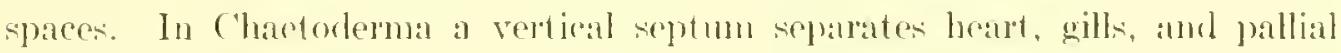
complex from the remainder of the primary bonty mity. It is not present in the Neomeniidar nor in Limifossor. In the last named genus there is an actitional partition, essentially the same as in the Chitons, which soparates the head eavity from the sureceding portions of the hamoucle. It is perforaterl by the aorta, almentary canal, and a perlal sinus which passes forwated into close proximity to the mouth.

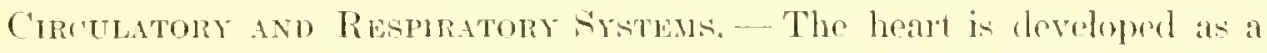
fold of the doral perieardial watl reinforeet hy a varying number of muscle fibres, and in some specios differentiaterl into an auricle and vantricle. From its anterior and the anda arises and passing dorsal to the gonad leads into a more or bess definite lead eavity. In the chactodermatina and al very few Neomenina this ressel possesses definite walls; in the others it is part of the general lacumar network. In Limifossme a distined connective-tissur septum bound the head eavity posteriorly, but in the greater number of other species the blood spaces in the head region communicatoptyectly with those surromeding the mid gut. These last named sinuses are in conmunneation also with a rentral 
median pedal sinus eren though the font be absent. In the posterior end of the body the bood is eollected in a branchial sinus, if gills be present, or is conveyed to the posterior end of the heart by means of clearly defined channels in the neighborhood of the rectum. In the Neomenima the haenoghohin is rontained in the corpuseder, and in the Chactedematina by the plation.

In the Chetodermatiua two phume-like respiratory organs, which spring from the anterior wall of the cloatal ehanber, are in all essential resperts like those of the Chitons and are doubthess true etenidia, the space wherein they are confained being the mantle cavity. In the Nommenima such organs are alsent, though the cloacal wall may be developed into folds in some species of large size, penetrated by numerous sinuses and covered with a richly ciliated epithelium. It is believed by some investigators that such lamellare are incipient or degenerate etenidia but there is little to support such a theory.

Apart from these nreans it is probable that roppiration takes place over the surface of the body, especially along the ventral furrow if such be present. It has been suggested also that the great buceal fold may possess a combined respiratory and sensory function.

Nervous Sistan. - In the Solenogastres there is a more pronounced concentration of the nerve cells to form definite ganglionic enlargements than in the Chitons, and the nerves supplying the mantle-avity comples arise from a more restricted section, but in the arrangement of the brain, pedal and lateral ganglia, and the labio-bucal system there is a very distinct fundamental resemblance betweon the fwo orders. In every ease the lorain, watally if not always bilobed, is sitnated on the dorsal side of the allimentary canal about the intersection of the mouth and pharyx. From its anterior fare three pairs of nerves originate in the Neoneniina and innervale the bucal wall and the adjarent regions of the body. About the hases of the atrial aimi these tibres connect with acemulations of nerre cells which may be the homologue of the great ganglionio masses in eontan with the brain in the Chactodermatina. In this last numed gromp these ateresory nerve masses, ten in number in Limifossor, are connected with the brain by screral nerves and on the other hand give rise to fibres which immervate the sensory buceal plate (Mundschild). In what appears to be the most primitive condition thee pairs of comnectives, the pedal, lateral, and labio-luceal, take their separate origin from the bran as in the

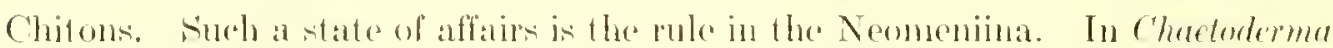
eruditu these cords unite inmodiately before plunging into the ateresory gandionie masses attached to the brain but retain a drieate comnective-tiswe sheath, 
and henee a perfect individuality, until they pass into the brain. In some other species of the genus, as for example Chactoderma nitidulum, they fuse indistinguishably as they enter the brain. Finally in Limifossor the podal and lateral rordis fuse a comparatively long distane from the brain, and at a less remote position are completely united with the labio-bucal comnective.

In every case the pedal ganglia are almost as long as the animal and hold a ventral position on each side of the pedal furrow though not always in close proximity to it. In several species commisures at fairy regular intervals have been seen uniting these cords, and erfually numerous connectives have been traced to the lateral nerves which hold a more dorsal position along the sides of the body. In the posterior end of the animal the relation of these elements raries considerably in the different speries. In Proncomeniu hawaiionsis, for example, the pedal cords become reduced in calibre, and finally break up into small nerves which have not been shown to have any connection with the lateral cords though they come into the neighborhood of some of the small nerves originating from them. In strophomenio serondens the last two or three latero-pedal connectives are of relatively large size and the union of the lateral and pedal ganglia is clearly established. Furthermore in several species, such as Lepidomemia hystrix, and Neomenia curinata, the posterior ends of the pedal cords terminate in ganglionic enlargements (ganglion posterius inferius, Wiren) united by a commissure of more than usual size situated ventral to the rectum. The posterior ends of the lateral ganglia are also frequently enlarged (ganglion posterius superius) and are invariably united above the rectum, thus completing in several species a circumrectal nerve ring. In the Chaetodermatidae the lateral and pedal ganglia are united, at least in the anterior end of the body, by commissures and connectives but more posteriorly these main ganglionic cords terminate in a large nerve mass. the so-called gill ganglion, continuous across the mid line above the rectum.

In what probably represents a typieal condition the sublingual or buecal system, in reality the labio-bucal, holds escentially the same relations as in the Chitons. Connectives lead from the brain along the pharyngeal wall and unite with ganglia about opposite the forward end of the radula or in the neighborhood of the openings of the ventral salivary glands. These nerve masses probably represent the labial and buceal ganglia of other molluses, and in at least one species, strophomenit semdens, are united by three commissures and the subradular system. One of these commissures, the dorsal buceal, crosses the dorsal side of the pharynx, while two pass ventral to it. In Proneomeniu hawaiiensis, where the subradular system is most highly developed, a connective arises from 
the immer face of (atch labio-buceal ganglion and unites with a small subradular ganglion which is in elose contact with a subladulas organ. These two ganglia are in turn mited by a subradular commissure. In the genus Chatoderma alio there is a well-delined subradular system (p. 57).

In soreral species of solenogatres various anthors have found what correspomets the labio-buceal connectives and ganglia, and in most of these cases have found one commisture which is either the ventral huceal or labial. In the Nomeniidae the subradular organ is usually wanting together with the "ustomary nerve supply; and in most species it is impossible to find more than one bucal commisure. Ilowever these nerves are usually very small and diffieult to trace so that negative evidence in this case may mot be entirely trustworthy.

Sense Organs.- In the majority of Solenogastres a dorsal sense organ exists in the mid line in the cloatal region. In the Neomeniina it consists of a rireulas dopression, naked or covered with a thin enticular layer, and surounded by spicules which in its contracted condition overareh it. When expanded by an underlying blood sinus a dise-like projection is elevated from the bottom of the depression and is raised above the suromnding spines. In the ('hatodermatina a groove, likewise overarehod by spirules when contracted, is probably a homologons structure. In both families these organs are imnervated by nerves from the dorsal commissure uniting the lateral nerve conds. Varions functions have been assigned, but without any experimental evidence.

Thele believes that the rentral furrow may he tartile but no semse cells have been shown to exist. In the gills on the other hand stiff hairs have been found among the cilia and are considered to be parts of sensory elements. Osphradial are unknown.

In the Chaetodernatidae the anterior sensory plate is innervated by a heary set of nerves and mobably acts as a tactile organ. Owing to the heary cuticular covering it may act also as a digging organ, operating in a general way like a hoges snout.

In Pronemmenid handiensis a low sensory ridge encireles the atrial wall immediately within its outer opening. It is composed of high cohumnar cells which rest throughout their entire axtent upon a red-like mass of neve aells. Internal to this are the wsual atrial ridges (Aundleisten), of which the more external elomely parallots the sensory tanct just mentionod, while the inner one pasies nearly aromel the eanal at the commencement of what is probably the month cavity. both are usually well-dereloped ciliated folds, apable, in some 
species, of great elistention owing to the large blowe sinuses contained within. Between the ridges the lining of the atrium is developed into simple or braneherl, finger-like processes termed rirri. Each is composed ol glamblular and sensory cells lirectuently pignented, and is penetrated by a slender canal travered by at nerve fibre. Regarding the function of these organs and the ridges it is variously considered that they are gustatory, ollactory or taetile, or eren respiratory. The cirri may be protruded from the oprening, and this fact in connection with their glandular character has wuggested that they may serve also to collect food; but judging from Diepunomeniu campyrella (page 79) there are times when they are inoperative in this respecet.

Regarding the papillae in the hypodermis of the Noomeniina varions hypotheses have been suggested. They appear to be comected with nerve fibres. and may reasonably be considered the homologue of the aesthetes in the shell of the (thitons, but up to the present time there is no proof that such is the case, nor that they are tactile, or secretory, or excretory, organs as some authols have matutained.

A sulnadular organ, normally located and innervated, is known to axist in a frw species (page 86). In its finer details it bears a striking rescmblance to its bomologue in the chitors and perhaps functions in the same way.

Cosuon.- The secondary body eavity comprises the amad, pericatelium, and enonoducto whose relations have been detemined in most of the known species of solenogastres although their physiological signifieane remains very incomplete. The gonald, watully paired, is situated along the clorsal side of tho andmal betwen the body wall and alimentary canal. Posterionly it is continnous, by mean of two ducts, with the perieardimm which in turn in in communicattion with the cloacal avity by means of two anals, the coehomoducts.

So far at known all the Clatodermatina are dioceious while the Neomenima are hermaphroditic, and generally speaking the gonad is of the same length as the liver and therefore nearly as long as the body in members of the lirst named suborder. In the soung the reproductive gland is paired, and in the adults with the execption of the genus Chatoderma this condition of affairs persists, thongh sometimes partially obseured by the development of numerous geminal folds. In the Neomenima the sperms arise along the outer walls of the glamd while the ora, in some species surounded by a follicle, are more inwardly placed. In the mature state the ora and spermatozoa make their way through the short, eiliated eanals terminating the gonad posteriorly, and enter the pericardium from whence they pass to the outside through coelomoducts of various degrees 
of complexity. In the young of some of the Neomeniina these last named canals are simple tubes of about requal calibre throughout, but in later life they become modified into a shell gland and one or more seminal receptacles. In adult ('haetodermat ina these cands remain comparatively simple, and there is some evidence that they function as exeretory organs as well as genital duets.

In wery case the coelomoducts originate from the hinder wall of the pericardium as comparatively small, ciliated tubes which pass anteriorly to about the level of the forward wall of the pericardium where they make a sharp bend and join the so-ealled shell gland in the Nenmeniina. At the intersect ion of these two livisions from one to twenty-five vesicular appendages are usually attached, which have nually been considered sominal leeptacles thomgh the arrangement of the sperms in a few species indicate that for at least a part of the broeding season they may function as seninal vesieles. Lis the distal ur ventral portions of the coelomoducts usually unite before entering the eloara the shell gland which they form is a bicornuate, comparatively swollen structure with excessively thick walls and contracted lumen. It is reasonably certain that this organ functions as a nidamental ghand, forming posilbly an albumenous envelope before the egg passess to the exteriors.

In intinate eonnection with the genital apparatus junt described there are a number of problematical organs which in some cases at least appear to have some role to play in the reproductive process. These include the genital spicula or peness such ats oceur in Neomenia earinate, Dorymenia acuminata, Pararhopulia pruvoti, Stylomenin salutori, and several other species. These are either relatively large ealcareous paired spincs, which ordinarily are enncealed in sheaths formed as anteriorly directed diverticula of the chacal wall, provided with protractor and retractor museles and in sone cases with a gland, or similar diverticula, may conceal numerous spines of much smaller size. While the function of these organs is unknown it is reasonable to believe, with several autlors, that they are excitants and posilly in a few species they nuty serve to attach the animals in coitu.

The preanal gland (Itubrecht), which in attached to the anterior face of the eloacal wall in Proneomenie sluiteri, and opens at the end of the pedal furrow or right and left under the cloaca, may be associated in some way with the reproductive process.

Pinssologr. - Several authors, notably Wiren, have alled attention to the striking resemblance between the C'hiton kidney and the corelomoducts of certain species of Chactoderma; and again the presence of erystals has been 
noted in these same organs. It thus beconns rery probalble that they aid in the removal of waste matters and at noted on page 169 the fact that the male and female grands are identical in form and structure indicates that they play no especially important part in the eger-laying process, merely conveying the orat from the perieatium to the exterior. In the Neomeniina there are certain indieations that the coelomoduets do not ereve as kidneys, and the fact that they are non-ylandular in immature individuals pointsalio to their non-excretory character.

In other parts of the body of screral other species of solenogastres there are organs of widely different character which are believed by various authors to hold the oflice of excretory organs. These inchude a number of structures which are in elese proximity to the choacal wall or are modifieations of it. Among them ate anal, preanal, or lysusus (improbable) glands probably not in all cases homologous and evidently in some species playing a part in the process of reproduction, apecially where they are museular, vesicular invaginations of the cloacal wall. Pruvot deseribed a mass of spongy, glandular cells in Myzomenia bamyulensis, forming a kw elevation on the floor of the cloacal carity, and containing yellow granules sinilar to others of larger size in the free cells of the umberlyge tisue. The supposition is that these last named elements are leneocytes, which, collerting materials from the blowd, pass them to the eloacal wall from whenee they are voided to the exterior. Thiele states also that in Promcomenia neapolitana there is an accumulation of cells irregular in form, forming a premal gland between the hypodemis and the somatio musenlature. similar elements are attached to the cloaleal wall, the rectum, and coelomoducts, and others of somewhat like character are found in the intestinal sims. Their resemblance to chlorogogue cells is marked, and for this reason chiefly they are belinved to excreise the sane function. Heath also has noted the presence of certain cells, along the rentral sinus of Limifossor talpoideus, whose shape and gramular contents suggest the eonnective-tisue, concrement-bearing elenents in the Chitons and other molluses as noted by Brock. The papillae have been looked upon as glandular bodies by several authors and of these a few consider them to be exerctory. On the other hand they may function ats urgans of special sertise (see page 40$)$.

Respiration to a certain extent probably ocems orer the general surface of the body, especially in those species with thin cuticle or where the euticle is provided with blood sinuses. The ventral groove, as several authors have suggested, certainly permits the interchange of gases. The walls of the atrial cavity, especially the cirri and ciliated folds are believed also to take a share in 
the prosests, and it has even becul suggested that the entire stomadh-intestine may he artive. In the chatedolematina definite etendia perform the respiratory function, white in the Neomenina the thin walls of the cloacal cavity, often thrown into folds, sometines of enormous size, and in contact with extensive blood sinuser, are undoulted artive agents in this respeet.

In some species, such as in . Hexumdromenia the atrial pidges are of large size and their superticial extont is increaned by the development of soconditry folds and papillate. Is these are penetrated by lange blood sinuse it is probable that they act to a certain extent as lexpiratery organs though it is doubtful if this is theil chiof duty. The cirri on the other hand never, or very rarely, contain blood spaces and ane very probably speedal sense organs.

As the functions ascribed to the varions sense organs, leal or sulpomed, have been tested experimentally in a few casces only, it is mot smprising that the opinions of autbors differ widely. Considering lirst the sense of touch it is probable that it is located over the general body surface, for living specimens of Chatoderma endite and C. montereyensis respond to merhanieal stimuli applied at any point. I number of investigators have noted the presenee of nerves in contanet with the hypoderentis in other species and Wiren has trared some of them into the deepor portions of the cuticle where they are supposed to function

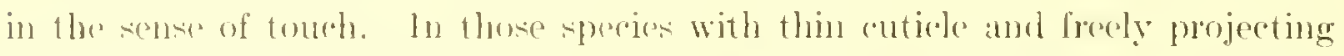
spines it is likerrise supposed that the latter sorve as tartile organs. This same activity is atsolibed atso by Thiele to sense cells which he has deteeted in the

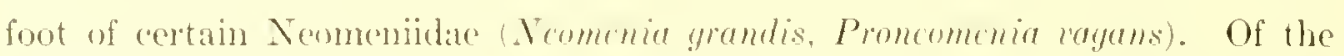
various activities which hate been comnected with the much discused papillate of the hyporlermis is the ability to distinguish viluations, amount of water presine, or more generalized stimuli affecting the tartile somse. It is to be noted, lowerer, that on the other hand these organs atre silu by sereral aluthors to be strictly glandular. A rematrable problematical retation of some of the papillae, consiclerably moditied, to the anterior coecmm of the stomach-intestine in Holomeniu grumide (p. 147) is diffieult to explatin on any hypothers.

From experiments Wiren linds the gills of Chatedoma to be very sensitive, and comsiders that the stiff hairs situated among the cilia are probably taletile. The buecal papillate are said by Heurcher to be argans of touch; they are certainly not universally, if erer, fond collecting oryans. In chose comection with the anterion bordor of the mouth of a few speries in a living endition Prurot, and Fowalersy and Marion hatre detected sensury hairs, that in some species are attacted to elevations, anparently the homologue of the sensong riclge, that 
I have fomel paralleling to some extent the outer bureal semory fold (p. st). Pruvot has noted that ats some of these animals progress they more the anterior end of the body from side to side, and appear to be using the organs in ruestion to detect the chatratere of their sumoundings, so that they mat be taetile. In Irhthyomeniat there are many pits, apparently ciliated, in the anterior end of the body. These are probably semse organs, hol of unknown function.

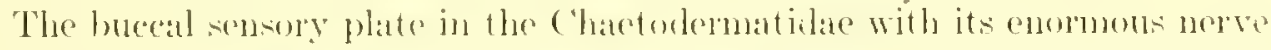
supply may rery probably lumetion ako as a tactile organ as Wiren and others have asimened, but it is to be noted that while this strueture takes an active part in the exeatration of burrows it is probalole that it serves to deteet the presence of foml. It all erents the alimentary camal of these animals is singulaty free from inormante materials, and in the alsence of any other well-defined organs in cor neal the buecal cavity it in not improbahle that the plate acts as an olfactory or more than ustally delinate tatetile organ. These same activities or posibly the semer of taste have been asigued to the frontal sense organ noted in the precesling paragraph.

The dorso-terminal groove in the chatentermatidae and its honologne in

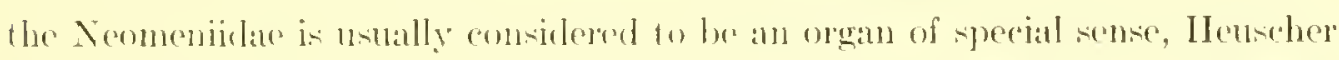
alone alleging the contrary owing to the fare that the depression in Proncomenia sluteri was fillod with detritus. This condition is not infrequently encountered in animals which have been exeavated from the material in a cherkge, but it is certainly not a momal state of affair. Comorning its function we have absolutely no positive evidener. It is reponted by Pruvot that it may hold the same ofliee as the frontal sense organ though the belief appears to rest upon nothing more tangible than a certain similarity of structure.

\section{C'LANEIFIC ITION.}

While the modification, by Nierstrasz, of Simpoth's scheme of chassification doubless fails of necersity to indieate aldurately the phylogenetic relat ionships of the solenogatsen it has the virtue of being more eonvenient than any other now in use and hence has been adopted in large measure. The family name l'arameniidae nust be disentinued. Coekerell (03) has shown that Prurot's genus Paramenia is preoceupied and has proposed the name Pruvotina, hence in the following table I have used a new family name Provotiniidae. The family 
Lepidomeniidae Nistr. containing Dondersia must retain Simroth's name Dondersidac.

As has been noted by other anthors the genus Pronementia as created by Hubrecht, has been much enlarged to include a number of speris some of which probably belong to other genera. Pronemenin weiner alpears to be very closely related to Dorymenia acutu and nay in reality belong to Dorymenia.

In the genus Strophonenia the long phatrix, the papillac and the numerous seminal receptacles are so characteristio and similar in the species of the present collection that I have no hesitancy in placing all in the same gromus. Pruvot's

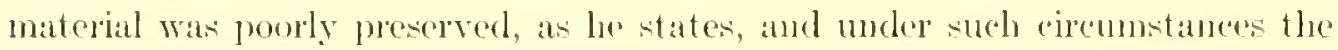
peculiar condition of the ventral salivary cramels is readily explained as I know from experience. The rachlat sac is likewise incorrectly placed, being much ton far forward. Evidently in Pruvot's species all traces of this organ have disappeared. With this revision the species are quite sinnilar. It is probable that Rhopalomenia indica Nierstrasz lulongs to this gents.

\section{Order IPLACOPIIORA v. IHERING.}

Suborder. I. Chactolematina simroth.

spieulose integment contimons all around the body.

Chaetodermatidar, p. 42.

suborder II. Noomeniina Fimmotls.

spiculose integument interrupted beneath by a longitudinal ventral furrow.

Nenmeniidale, p. 44.

Promeomeniilate, p. 45.

Piurotiniiclae, P. 47.

Dondersiilae, p. 48 .

CHAETODERMATIDAE SIMROTH.

Opening of month and anal chamber teminal. Body with more or less sharply marked regions. Lentral furrow and fold lacking. Two highly developed plume-like gills. Radula distichous, polyserial or strongly redued to a large mpared entieular tooth. The mill-gut possescese in most eases, a welldeveloped digestive gland. Copulatory apparatus lacking. Coelonoducts remain separate. Cuticle thin, spieules flat, often needle-form, but solid. Inlable jotton ooze. 
Chaetoderma Lovex, 1\$45,

Body vermiform, without ventral groove; mouth and anal chamber terminal. Two gills. Sexes separate. Radula reduced to conical peg. Type of genus ( $\mathrm{c}$. nitidulum.

C. argenter, sp. nos.

Length $24 \mathrm{~mm}$. by $1.6 \mathrm{and} 2.6 \mathrm{~mm}$. through the metathorax and preabdomen repeetively. Silvery white. Spines, in side view, usually bent. Maska. (1). 62.)

C. attenueta, s]) nov.

body long and sender, measuring $61 \mathrm{~mm}$. in length by 1.5 through the metathorax and 2.7 through the prabdomen. Buecal plate relatively small. Maskia. (p. 55.)

C. californica, sp. nov.

Body moasuring $24 \mathrm{~mm}$. in length hy $1.6 \mathrm{mmn}$. greatest diameter. Larger spines with expanded bases. California. (p. (it.)

C.credita, sp. nov.

Arerage length, in preserved state, 27 mm. by $2.5 \mathrm{~mm}$. arerage thickness of preabdomen. Buceal plate deeply eleft by mouth opening. Brain of large size. Mlakkia. (1).59.)

('. hanaizensis, sp. nov.

Body slender, measuring $12-19 \mathrm{~mm}$. in length by $0.5-0.6 \mathrm{~mm}$. greatest thickness. Buccal plate broadly elliptical, perforated in rentre by mouth. Hawaii. (p. 49.)

C. japonica, sp. nov.

Length $17 \mathrm{~mm}$. by $1.5 \mathrm{~mm}$. greatest thickness, buecal plate shicld-shape, perforated by mouth opening. Japan. (p. 67.)

C. montereyensis, sp. nov.

length $45 \mathrm{~mm}$. hy $3 \mathrm{~mm}$. greatest dismeter. Buecal plate umsually large. Tooth stout. Monterey Bay, California. (p. 61.)

C. memula, sp. nov.

Body small, comparatively stout, measuring $9 \mathrm{~mm}$, in length by $1.4 \mathrm{~mm}$. greatest diameter. Spines keeled and of heavy appearanee. California. (p. 66i.)

C. robusta, sp. nov.

Body heary, measuring $60 \mathrm{~mm}$. long by 3.5 and $4.7 \mathrm{~mm}$, through the meta- 
thorax and prealdomen respectively. Buceal plate shield-shape. Largest spines relat irely slemer without definte ked. Alaskil. (p. fis.)

C. scabra, sp. nov.

Small, measuring $12 \mathrm{~mm}$. in length by 2 mm. greatest diameter. Body wall relatively thin. Brownish, becoming olive-green in region al digestive gland. Monterey Bay, California (p. (i3.)

\section{Limifossor HE.1TH, 1904.}

Body short. Radula very latge, distichous, with twenty-eight transwerse rows in L. talpoideus (about the same number in L. frotula). Dorsal salivary glanels present. Stomach and digestive gland well developed, and distinet from intestine. Type of gemms, L. talpoidrus.

L. fratula, sp. nov.

Slaty gray with yellowish cast. Spines from middle of body 0.5 mm. long. Length index 1.3-4.7. (alifornia. (p. 72.)

L. talpoidens.

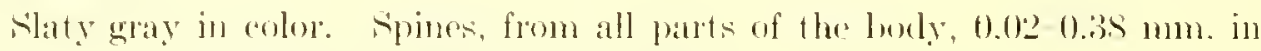
length. Iength index iti. Mlaska. (p. (i9.)

\section{NEOMENIIDAE SIMKOTH.}

Budy compressed, more ol less aresent-shaped, without distinet divisions. Index 7 at most. Oprening of atrium ventral, of the anal chamber ventral or terminal. V'entral furrom present, dsually with soveral folds. Cuticle sometimes comparatively thick, spines mostly neelle-like, flat, gromed, or hollow. 1 eirelet of gills in the anal wamber. Ratulat and salivary glands unally lacking. Epidermal papillare of simple strueture, ustally present. Fore gut protrusible. Conlomoducts separate or unitod to form shell gland or copulatory

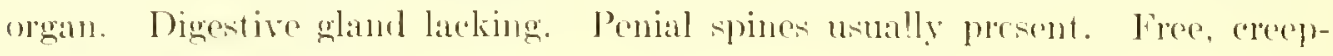
ing about over bottom.

Drepanomenia, wn. nus.

Body short and thick. Hollew merdle-like spims with trumated bases; slender stalketl papillate. Ventral salivary ghambis long and tubular. Coelommduets simple, without appendages. No copulatory apparatus. Type of genus D. cumpyrella, sp. nov.

With characters of the gemus. Hawaii. (p. TT.) 
Pachymenia, gen. nov.

Body stout, measuring 27 by $4.5 \mathrm{~mm}$. One layer of awl-like spines, papillac mulicellular with broad bases, pusteriorly ill defined. Pharynx very large and muscular with numerous glands some of which open by one pair of duets at forward border of pharyn. Dorwal and rontral limbs of coelomoducts provided with mumerous glands. One pair of small seminal reeptades. Cloaral wall covered with ghands except region of branchial folds. No copulatory spines. Type of genus

P. abyssom, sp. nov.

With characters of the genus. ('alifomian. (p. 72.)

PRONEOMENIIDAE SIMRUTH.

Wom-like. Radula distichous or polystirhous, sometimes larking. Salirary gland tubular, lobed or lacking. Cuticle thick, spicules mostly needlelike in several layers. Epidermal papillae present. (iills usually lacking. Coelomoducts usually united into shell glamel, somotimes separated. Copulatory apparatu< may be present. Free living, partly or ent irely parasitic.

Proneomenia HénRerit, 1〈ivo.

Burly elongated, vermiform, the length 9-50 times the diameter. C'oara opening ventral. Foot present, the groove pasing into the chata. Cuticle thick with crowded spicules. No gilks. Radula multidentate. Two salivary glands. Copulatory ormans present or absent. Type of genus, P. shiteri.

P. haw ainensis, ip. nov.

Length 36 by $2 \mathrm{~mm}$. Dorsal and ventral salivary glands. Radula with 39-40 treth in each transerse row. One pair of seminal receptacles. No copulatory organs. Hawaii. (p. S2.)

P. insu'mis, sp. nov.

Anterior end similar to the foregoing species (posterior end miscing). One pair long, tubular salivary glands. Radula polystichous with 28 transverese rows. Hawaii. (p. 90.)

Driomenia, gen. nov.

Measurement 9 by $1 \mathrm{~mm}$. C'uticle thick, papillae present, spines needleshaped, slightly curved. Itrum separate from mouth opening, no radula, one pair groludar ventral salivary glands. Antero-lateral pericardial wall prolonged 
into a pair of horn-like pouches. One pair seminal receptacles. No eopulatory spines. Gills abent. Type of genus

D. pacifica, sp. nov.

With (hatacters of the genus. Japan. (p. 93.)

Dorymenia, gen. now.

Vermiform, body terminating posteriorly in a finger-shaped elongation. Radula polystichous, with $48-51$ longitudinal rows of 22 teeth each. One pair of reminal receptacles. I pair of long copulation spicules alsely asociated with : pair of globular coeca likewise opening separutely into the chaca. Type of genus

D. acutu, sp. nov.

With the characters of the genus. Californial. (p. 95.)

Strophomenia PRUYOT, 1 s99.

Body elongated, eylindrical, the thick cuticle penetrated by acieular spicules and closely crowded vesicular papillae; radula and salivary ducts, eamblat sense organ sometimes absent (?); two distinct genital openings into the cloaca. Type of genus, S. lacazei.

S. farcimen, sp. nov.

length 18 by 2 mm. Papillae smal', alosely erowderl. Ratula with 15 transverse rows of 24-28 teetl. 19 seminal receptacles. Japan. (p. 119.) S. ophidiona, sp. nov.

Length 43 by $2.5 \mathrm{~mm}$. Papillac fairly numerous. No radula. 23 small seminal receptades. Iapan. (p. 112.)

S. ingularis, sp. nov.

Anterior end mising. Papilla small, closely erowded. 12 seminal receptacles. Japan. (p. 116.)

s. semmlens, sp. nov.

Length 32-39 by 1.6-2.1 mm. dianter. Papillae arowded. No radula. 15-18 seminal receptacles. Hawaii. (p. 106.)

S. spinosa, sp. nov.

Length 28 by $1 \mathrm{~mm}$. Papillae few. Radula small, monoserial or biserial with 8 transterse rows. 12-31 seminal receptacles. Japan. (p. 122.)

S. triangularis, sp. nov.

Length $12 \mathrm{~mm}$. by $1.6 \mathrm{~mm}$. diameter. Triangular in cross section. Radula 
distichous, apparently comb-like with licups in each row. Sominal receptacles 10-12. Jар:แ1. (p. 125.)

PRUVOTINIIDAE, noIn. nov.

Worm-like. Cuticle, as a rule, thick; spines as in Proneomeniidae or bonk-like. Epidermal papilate present or alsont. Radula distichous, simple or double comb-form, or lacking. Sillivary glands globular, lobed or tubular. Cill folds present. Coelomoducts united to form unpared shell gland. Copulatory apparatus may be present. Tentral furrow and fold present. Free or living on colral, ote.

\section{Lophomenia gen. nov.}

With dorsal keel; length 24 mm., diameter 1.5 mm., 3 ventral folds. Cuticle thick, with mumerous needle-like spines in several layers; papillate fow, chubshaped. Radula distichous, 20 transwerse rows. Dorsal salivary gland large; ventral glolular. 2 seminal reeptacles, 2 bundles of many ropulatory spines. Typo of gents

L. spiralis. sp. nov.

With characters of the gemus. Hawaii. (p. 129.)

Alexandromenia, gen. nผพ.

Body relatively short and thick, longth $25-32 \mathrm{~mm}$. by $3.5-5 \mathrm{~mm}$. dianeter. Spicules small needle-like assoriated with larger radially directod ones. Papillae very large, multinucleate. Foot, 59 folds. Gill folds 20-40. Numerous pharymgeal glands and emomons lobulated glands opening on the sides of the pharymx. Radula monoserial. 1 pair seminal receptacles. Type of gems

A. agessizi, sp. nov.

Posterior end truncated, gills exposed. Monoserial radula with slightly curved rectangular teeth. to gill folds. (alifornia. (p. 133.)

A. malidu, sp. nov.

Posterior end rounded, cloara opening ventral. Teeth with two horn-like projections. 20 gill folds. ('alifornia. (p. 142.)

\section{Halomenia, gen nx.}

Budy short, length index $7: 1$. Ajpoules needle-like. Papillae large, in places resting upon diverticulat of the mid gut. 2 ventral folkls. (iills $20-30$. Radula distichous. 1 pair seminal receptarles or vesicles. Type of gems II. gravida, sp. nov.

With the charaeters of the genus. Fimile Islands. (p. 146.) 
DONDERSIIDAE SIMUTH.

Burly often worm-like. Cutiele thin: spines flat and solid. Papillae lacking. Radula distichous, monoserial or lacking. Salivary glands glolular, sacor tube-like. Cill folds larking. Corelomeduetsunifed or separate. Copulatory apparatus may be present. Ventral fold and furrow may be absent. Living free, or on corals, ete.

Herpomenia, gen, nov.

Length $11-18 \mathrm{~mm}$. by $0.6-0.9 \mathrm{~mm}$. Font smoothed out, viliated. Ventral

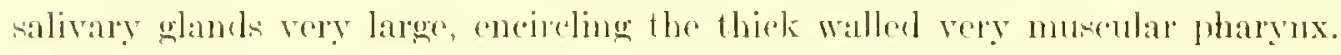
Radula larking. I pair seminal receptacles. Shell gland almost globular. Type of genus

H. platypowla, ep. nov.

With the characters of the genus. Neutian Has, Mlaka. (p. 151.)

Dondersia IIUBRECHT, ISSE.

Body long, longth index 10-4s. I ventral fold. Spicula needle- or spatulashaped, flit. cuticle very thin, no papillae. Dorso-teminal sense knots prexent. I pair of shert ventral salivary glands, which unite before opening

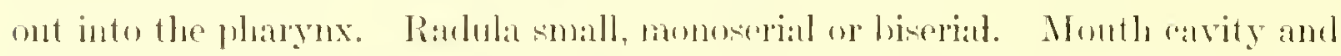

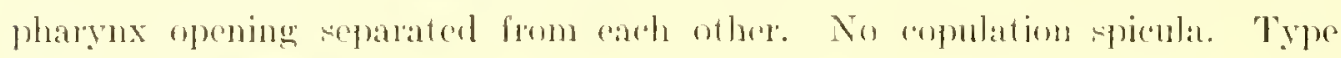
of gemuls, D). fostim.

D. califarmica, sp. nor.

Dowal malivary wankis very seant; vontral small. Radula with at least 12 pairs of teeth. Inmmature. Californial. (p. 15is.)

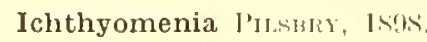

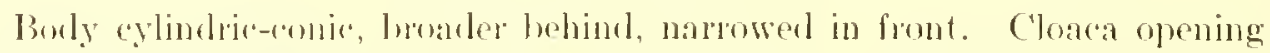
at terminal transerese slit, at prominenes in font of it. Foot gromere and foot present, disappearing posterionly. Cuticle not papillose, the ventral spicules leaf-shaped, the rest sade-like, imbriating. No gills. Radula well developed or melinentary, with apparontly two lows of teeth. Length 5 to 13 times the breatlith. Type ol genus, $I$. ichlhyodes.

1. Huresas, s]). $110 \mathrm{y}$.

Bonly palc yellowish white, 16 mm. long by 1.2 mm. thick. Scales lish-like and ednde-shaped. Upwards of be sensery pits in the anterior end. No radula. California colat. (1. 159.) 


\section{DEACRIPTHON OF SPLCIEA.}

Chaetoderma hawailensis, sp. nov.

Two speeimens of this species were dredged in the viemity of Kanai Island. The first came from the western end (Sta. 4130) at a deptlo of 283-309 fith.; the second from the northern extremity, Mokuaeae Islet (Sta. 3992), at a depth of $52 \mathrm{~s}$ fath.

The first specimen was found in a mass of polyps of Epizonthus (Plate 2 , fig. 3) elevated at least a foot above the bottom, and densely matted together in such a manner as to preclude the posibility of aceidental lodgment. The second individual was found by Dr. W. K. Fisher among the spines of a species of starfish (Odinia pacifice Fisher) also in such a position that it could seareely be due to aceidental shifting. There is no especial reason for eomidering this species a parasitic form nor indeed a commensal, for the food in the alimentary canal consisted of small quantities of plant spores, sponge spicules, and organic debris such as is ordinarily foum in those species that burrow in the ooze. It seens more probable that it, like Chartoderma nitidulum, as desoribed by Wiren, may leave its burrow to eraw about on the bottom, or as in the present case even on the bodies of other animals.

In its external features this speries displays the usual eharacteristies of other members of the family. The body including the globular and apparently non-retractile prothorax, itself about $2 \mathrm{~mm}$. in length, is $12 \mathrm{~mm}$. long. Immediately behind the swollen part of the prothorax the diameter of the body is 0.65 mm., and this continues with little change through the anterior half of the animal. Beyond this point the calibe gradually inereases to $1 \frac{1}{3} \mathrm{~mm}$. in the neighborhood of the eloaca, beyond which a slight decrease oceurs that continues to the end of the body. In the other specimen the size of the prothorax is the same, but the length of the metathorax (19 mm.; diameter $0.5 \mathrm{~mm}$.) and the abdomen ( $7 \mathrm{~mm}$; diameter $1 \mathrm{~mm}$.) is considerably greater and bears witness to the futility of using the length index in the discrimination of some species.

The color of both specimens is a slaty gray, though this is usually obscured by an inorganic incrustation covering the body generally. In the region of the metathorax the larger spines are conplotely hidden in a granular deposit that gives this part of the animal a briek-red shade. The same substance, in one case black in color, is present in several other species of Chaetodermatidae in my possession, and may perhaps be an exeretory produet thrown out from the coelomoducts. 
The cuticular plate covering the frontal sense organ is almost circular in outline and is elevated above the general surface of the prothorax. This is espeeially the ease with the lateral portions which assume the form of pronounced folds decreasing in height as the centre of the organ is approached. 'The boundary betwen the cuticle and the underlying epithelial colls is not sharp and the outlines of the cells themselves are not clearly visible. The greater number appear to be sensory elements and are distinguished by thoir relatively slender appearance (the diameter being to the heiglat as one to four) and by darkly stuining elongated nuclei placed in the basal half of the cell. Among these are a few cells of the same height, but of greater diameter, which contain spherical centrally placed nuclei with a small amount of chromatin. (ireat numbers of ganglion cells are situated in immediate contact with this sonsory plate, and some of the more deeply seated clearly connect with nerves passing out from the precreloral ganglia (as I have termed the great accumulations of ganglion cells in contact with the brain in the (haetodematidae), and on the other hand originate fibres that pass down to the frontal organ (l'late 28 , fig. 1). A rery fow small pyriform gland cells, staning almost black in hacmatoxylin, extend from the midst of the ganglion cells to the sense organ where they probably open to the surface. Large numbers of muscle filores attach also to the sensory epithelium and at several points there are indieations that they pass between the hypodemal cells and connect directly with the overlying cuticle.

The hypolermis is practically the same as in other species and not particularly favorable for the solution of any of the several problems comnected with it. Its cells differ considerably in form and appearance. In the swollen part of the prothorax they are slightly higher than broad; in the metathorax the reverse is true; while in the abdominal region the height is alsout twice the diameter. Everywhere their boundaries are indistinet, and thus unlike the sharply defined central nuclei. Here and there are more slender elements with elongated darkly staining nulej, and somewhat more numerous are the basal cells in contact with the hase of the overlying spicules. These latter colls vary widely in general appearance from rery small compact elements to others large, globular, and much vacuolated, owing to difforent stages of development and probably to some extent to mechanical compression. No pigment cells exist, nor wandering cells nor other elements that are sufliciently different from the usual constituents to be placed in a separate "atagory.

The spicules are of the usual spearbead shape, and form a continuous scries of increasing size, from those of the prothorax with a length of $.0275 \mathrm{~mm}$. 
to others on the postablomen, 225 mm. long. Plate 37, fig. 12, gives an acentate idea of the usual type of spine, these lecing from the middle of the metathorax.

The mouth opening is situated albout the centre of the frontal sense organ and is remarkable for its minuteness. From here to the region of the radula the canal is relatively small, not exereding one seventh of the greatest diameter of the prothorax. It is invested by a thin layer of museles and is attached also to a considerable number of seattered fibres that pass outwald and are inserted in the body wall. Camglion eells arranged in gronps as in the Neoneniidae are also fastened to the buecal mass. The epithelial lining eonsists of high columnar rells with basal nuclei imbeded in modrately dense cytophasm, that more distally becomes filled with a fincly granular colorless secretion. In one specimen particles of a golden yellow color oceurred in, or between, some of these clements, but whether they were developed in situ, or had been produred hy rells more externally placed, it is inpossible to determine.

While in one specinen the digestive tract continues of about the same calibre througliout, the other expands widely in the region of the radula, and at the anterior end of this enlargement a eircular fold is present that is probably homologons with the proboseis of Drepanomenia, for example. In one individual this swollen section is almost completely filled with diatoms, plant spores, sponge spicules, and organic remains some of which appear to have been mixed with some viscons secretion and moulded into globular masses.

From a point corresponding to the hinder border of the globular part of the prothorax to the anterior end of the preablomen, the wall of the digestive tract is relatively thin due to the saraty of muscle fibres and the lowness of the epithelial cells. The latter are columnar elements of medium height with spherieal basal unclei and an abundance of a fincly gramular, light yellow substance filling the entire distal half. It various points throughout the prothorax and motathor:ax this sulstince is in the act of eseaping in the form of droplets eonstrieted from the cell, and all stages exist between this and the development of a fincly gramular secretion filling the canal. Cells lreed of this secretion are cubieal in form and are usually relatively dense. Cleared specimens show that while in this part of the gut true pouches do not exist the canal is by no means entirely straight, wrinkles and folds ocenring throughout, thongh they lack the definiteness and regularity of the dilations in the Nomeniidae.

At the level of the front end of the gonad the derelopment of digestive fluids becomes relegated to a sot of cells that form a large divcrticulum extending to the hind end of the body. In this digestive ghand, judging from the material 
in hand, two distinct kinds of material ane secreted, but in widely differing quantities according to the locality. The cells attaned to the gomad are masully more or less pyriform with companatively small, dense almost homogeneous muclei placed basally, while the remaining protoplawn is closely packed with immomerable granules. By far the greater number of these are spherioal and ol yellow or stightly greenish yellow tint. They are liberated, as is the seretion in the more anterior parts of the gint, by the comstrietion of droplets from the distal end, and may be seen undergoing disintegration and solution in many different places. Among the granules of this chatactor are others in the form of small particles of a distinct pink or riolet color after treatment with haematoxylin. They have exery appearance of being an end product and not a stage in the development of the more abundant secretion.

Elsewhere in the ghand the ectls are of looser texture, the basal muclei are relatively larger and granular and many if not all contain the two sprecies of seeretion just described. Cienerally the yellowish product is seant in amount, while in many cells the violet tinted substance arecumulates in splerical or elliptical masses, smmonded ly a vacuole in preserved specimens, that ahmost fills the cell. These serretory products are passed out entire, and in a single section as many as twenty-fixe nay hold positions in the lumen of the gland. Making their way forward many if not all pass into the intostine, and here may be seen in varions stages of solution, forming at first a raenolated product that before dissolving completely transforms into a finely granular material of maroon rolor after treatment with hamatoxylin.

The cerls of the intestine are cubical in form and in front of the pericardium show sigh of slight glandular artivity. Behind this point this phase of activity disappears, and cilia become developed and continue to the opening into the cloacal cavity.

The large size of the ganglia and the abundance of the nerve cells that envelop them and also the sharpmess of even the smaller nerves renders it possible without much effort 10 gain a very elear idea of the norvous system of this species (see Plate 7, fig. 2). As is them shown the brain, located some distance above the digestive tract, is distinctly enveloped in a delicate comectivetissur sheath and is clearly bilobed in fom though its outlines are somewhat obseured by great masses of ganglion cells (forming the precerolual ganglia) attached dhiefly to its lateral and anterior surfare. A ronsiderable number of delicate fibres, pasing ont from the brain, attach to these ganglionic bodies which in tum are connected with linge numbers of nerve fibres that pass ehiefly to the walls of the mouth and the fontal sense organ. 
This part of the nervous system is thus escentially an we find it in other

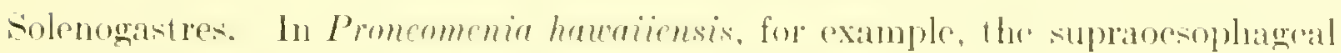
ganglia are comnerted with several nerves some of which unite with gronps of ganglion cells attached to the bases of the rirri, and from these again other norves pass to the digestive traet and probably to the boty watl. In Chatefoderma the chief difference is that the norves uniting the brain and precerebral ganglia are very short.

In the present speeips the pedal and lateral comnectives unite inmediately before plunging through the preserebral gatuglia, and as Plate 7 , lig. 2 shows the labio-bucal cord unites wh then before the brain is reached. This same condition of affairs exists also in two species of this genus taken in Mlaka, thongh much more ohscured than in the present species. It the postrior end of the prothorax the pedal and lateral cords that have gradually approached cach other actually come in contact and in one specimen even fuse for a short distance and lose the usual sheath of ganglion cells. Intrione to this point two pedal commisures exist, but until the hindmost part of thr body is reached no farther trare of such nerves has been found. On the other hand latero-pedal cunnectives are present throughout the entire length of the animal.

The relations of the labiu-buecal ganglial are represented in llate 7 , fig. 2. The non-ganglionic eonnectives imbedded in the pharygeal wall unite with the superficially attached ganglia, that are also united by a commissure pasing behind the median tooth. In front of the radtala there are connectives giving rise to nerves passing dorsally to what is probably the subractulat organ and in addition attadhing to a ganglionic mass in the mid line. As this part of the nervous system appears with greater distinctuess in $\mathrm{r}$. attemente it is more fully described in that eomsection.

Throughout the entire metathorax the lateral and pedal cords pursue their course almost in contact, here and there giving rise to nerves that sons disappear, and finally join in the extreme posterior cnd of the body. Shortly after their union they are connected hy a heary ganglionic eommiswe pasing dorsal to the intestine. In the mid line it develops a single nerve that makes it way into the tisue of the rectum, while on the dorsal side four fibres miginate, two of which pass at onee into the gills while the others attach to the inner side of the cloacal epithelium, and branching repeatedly supply this mombrane and the dorsal body witl and a well-marked fold of the hypodermis to he described presently. It the junetion of the latero-pedil cord and the commissure a nerve arises that pakses backward and appears to supply the ventral body wall of the eloacal region. 
Owing to the debris encrusting the posterior end of the body it is imposible to determine the position of the dorsal sensory groove in entire specimens. In sections it is seen to oreupy the usual position, that is from the extrene hinder end of the animal forward to a point almost immediately above the level of the anal opening. Is is represented Plate 6 , fig. 8 , it consists of a relatively deep fold of the hypodermis, that anteriorly rapidly disappears but is continuous with a ridge-like elevation in the mid dorsal line extending for a short distance more anterioly. Some of the spines of the immediate neighborhond are of comparatively mall size and orerarch the depression, which is also covered by a thin continuation of the cuticle investing the body.

The cells of this organ consist of those eommon to the hypodermis, and others which are much more slender and compact with spindle-shaped nuclex usually subeentrally placed. The latter elements are probably sensory and connect with small groups of ganglion cells holding pwitions immediately beneath the circular somatie muscles in the neighborhood of the organ, and on the other hand are undoubtedly rolated with nerves from the branchial ganglia. That this is a definite sense organ and the homologue of the dorsal organ of the Neomeniidae, as maintaned by varjous authors, there is lit tle doubt, but there is nothing that more definitely establishes its function.

The gonad cxtends form the front end of the metathorax to the pericardium with which it is mited ly two short and comparatively wide duets. Both speeimens were sexually mature males and considerable quantities of spematozoa ocrupied positions in the pericardial cavity, and at varions points in the eoelomoduets. These last mentioned organs arise from the postero-fateral borders of the pericardial chamber in the form of clearly defined tubes, whose cells are nearly "uhical in form and support an ahmdance of large cilia. Bending sharply inward each becomes contimusus with a canal, of mucll larger size and different structure, that after extending forward for a short distance pursues an irregular course opening symmetrieally on each side of the rectum. The large non-eiliated portion of the duets is composed of rather low rells with well-defined, hasully placed nuclei, in which the chromatin exist in the form of a moderate number of sharply defined granules. In the more distal part of each eell is a sharply defined vacuole, in which are one or two light greenish yellow bodies, having the appearance of eoncrements such as ofeur in the kidneys of several molluses. At various places these are in the art of escaping through the ruptured or diswolved end of the cell or having beeone free are undergoing a process of solution. Such an appearanee in the kidney of other molluses would not in any way appear unumal, 
and leads to the irresistible comelusion that here the coelomolucts are not only morphologiestly rebated to the renal organs in the Chitons or other molluses, but phyiolologically also as Wiren first clearly stated.

\section{Chaetoderma attenuata, sp. nov.}

Eight specimens of this speeies were dredged near the southern limit of Alaska, buried in glacial nud brought down chiefly by the sitikine River. One from Kasaan bay (sta. 4241) occurred in green mud at a depth of 50 - 54 fathoms; tive opposite the mouth of the Nitine River (Nta. 4250) were in the same habitat at a depth of tit-60 faths; while two in the waters of Stephens Passage (sta. 4252) were huried in gray mud at a depth of 198-201 fath.s. Their appearance in life, Plate 4, fig. 3, answers elosely for preserved material. The type specimen measured $45 \mathrm{~mm}$. in length by $1.7 \mathrm{~mm}$. through the metatherax, and $2.6 \mathrm{~mm}$. through the abdomen. The color of alcoholic material, which is the same as the living save for the pinkish tinge due to haemaglobin in the head and gill region, is almost white with a tinge of yellow, beconing graysh where the liver is lociated.

The body wall, including muscular, hypodermal, and cuticular layers. is of median thickness and is typieally located, but in specinens killed in rom Rath's fhuid eertain elements appear that have not been fully described, though they probably occur in all species of the genus. These are the so-called giant rells (Rierenzellen Wiren) which in ordinary material present the form of empty vesicles with the nueleus imbedeled in the wall. In life this cavity is tilled with a secretion, that after treatment with fluds containing osmic acid, is granular as Wiren has renarked. In favorable situations it may readily be seen that fibres, muscular at least in part, extend from the somatic muculature and penetrating the hypodermal layer attad to the sides of these eells (Plate 25, fig. 7). Appearances suggest that the secretion, upon the contraction of the fibres, is forced into the neighboring lacunae, but in no case has this leen actually observed though proximally the cell may be produeed into a comparatively slender, short stalk. Distally the colls are wasully in close contact with the free surface of the cuticle and prosent a shaply defined rounded appearaner. Posteriorly these elements become somewhat less numerous and of smaller size. In alcoholic: killed miterial the fibres may be distinguished, but their attachment to the eell body is very indistinct.

Wiren ('92) states that these giant aels are not sharply differentiated from the batial matrix cells of the spicules, but this refers, so far as I am able to judge, 
merely to their form as the spieule mother cells do not contain any clearly defined granular secretion. On the other hand the matrix cells shade much more perfeetly into the cubical clements that probably form the cutiele.

The mouth, placed in a cleft on the dorsal side of the buceal plate, opens into a tube whose form and genoral appearance are represented (Plate 25, fig. 1). The lining epithelium consists of the usual high columnar cells produced into several irregular longitudinal folds, through whieh the outlets of the buceal glands make their way. These last named organs are comparatively abundant, especially on the ventral side of the pharyux, and extend from the region of the brain to the radula.

A subradular organ certainly exists in this and several other species, if position and innervation be auy crifcrion. In material killed in rom Rath's fluid it appears with the greatest distinctness as a sharply defined median area composed of high columuar cells situated immediately in front of the peg-like tooth (Plate 25, fig. 10). In alcoholic material the appearance is not so striking, and yet there is very little dilliculty in distinguishing the organ. However, with such material it is sometines a lask fo determine its innervation. Nerves in the immediate vicinity are usually visible, but to trace these into the ganglia is frecuently a perplexing operation. In rom Rath's material on the ofler hand the entire system is clearly differentiated (see section on nervous system).

The radula and its supports (Plate 25, fig. 2) are of comparatively large size but are typieally arrunged and recpure no especial description. Beyond the radula the gut becomes cireular (Plate 25 , lig. 3), the epithelim relatively high and a linely granular secretion fills the distal two thirds of the component eells. Among these are a very few more globular elements with a datrkly staining more granular seretion. Beyond the pharyx the gut widens, the cells berome lower and slightly glandular with the exception of a very few cells containing a yellow secetion. Beyond this point the relations of stomach, intestine, and liver are typieal and recfuire no debiled description.

The brain and anterior portion of the nervous system alosely resemble what is found in $C$. cruditu, and so reguire but little additional description. It appears that the labio-buceal connectives have an origin independent of the lateral and pedal, which as in C.erudita unite before entering the brain. The commissures of the pedal cords are relatively more slender than those of $C$. erudita, save the anterior one which is of exceptional thickness. In some eases nerves arise from the commissures and are distributed to the body wall.

The labio-buecal system is of unusual interest since it possesses what may 
he eonsidered to be a subradukar system with ganglia and connectives with fibres passing into the above dereribed orean in front of the ralula. The labio-buecal comnectives pass backwand ats usual and unite with fhe well-known ganglia imbedded in the pharymgeal numsulature: and these bodies are in turn mited by a cort in which two small gatnglia are interealated. A nerve which apparently bas escaped observation arises from the posterior surface of atub of the larger ganglia (Plate 13, fig. 3), and imberded in the pharyngeal wall may be traced to the forward border of the stomach.

I short distance in front of the bubio-buesal gangliat a clearly defined fibre arises from each of the comnectives (Plate 13, fig. 3), and, imbeded in the muscle of the pharyen, courses downward and inward and joins a ganglionje mass that gives sight evidence of being paired (Plate 25, fig. 10). To the ontsicle of the ganglion (or ganglia) a nerve arises from each of these connectives uniting with the labio-buceal connectives, and coursing dorsally attaches to the batec of the sulmatular organ.

There is absolutely no dombt of the existence of this system, the grayish nerres showing with great distinctness against the yellowish musele fibres in matrial killed in vom Rath's lluid. In material fixed in aleohol on the other hamd it is sometimes difficult to trace. The ganglionic mass may closely resemble a salivary gland and the nerves from if counterfeit muscle libres; nevertheless with an oil inmersion lens I have been able to demonstrate its presence in all the species of the genus describer in the present paper, and in al specimen of ('. nitiduhum kindly sent me by Professor Hubrecht. As is more fully noted on page 172. I believe that the ganghion and its commectives constitute a sulnadular system the homologue of the one I have described in some of the Neomenibiace.

Posteriorly the pedal and lateral ganglia mite in the customatry farhion, and at the point of mion give rise to two small nerves which become chosely applied to the body wall, and after branching are lost fo sight among the longitudinal somatic musele fibres. From the suprareetal ganglionor mass (Plate 12 , fig. 4), several branches arise somo of which appear to have escaped observation, or at all erents have not been traced to any eonsiderable extent. (Of these the larger pair originate from the ventral side of the ganglion and make their way ventrally to the sides of the reetum, where acording to Wiren's figures and description they diminish very lapidly in clianeter and form a delicate subrectal commissure. In the present speeies this is eertainly not the case, nor is it true of ('. crudita, for arriving at the reetum each follows it posterionly to the anal opening, and then passes outward ahnost at a right angle and beromes imbedked 
in the ventral gill potraetors and in this position may he traced almost to the alpex of the gill. botween its point of origin and its attaxhment to the rectum at least four small nerves arise and extend fan-like into the vent rat gill retraters which they probably innervate. I lave been malble to find any subrectal ronmmisure.

From the dorsal side of the suprarectal commissure four nerves arise, of which the outermost pair extends dorsally through the superior gill retractors, and imbedded in the dorsal cloacal wall, which it probably innervates, may be followed for a very considerable distanes. The immer pair pursues much the same route at first, but upen emerging from the dorsal jootractors and while imberded in the cloateal wall each nerve turns sharply upon it-df, and bending slightly fowad the mid line and somewhat ventrally it enters the dorsal gill retractor and in this position may be followed close to the tip of the gill. Each of the branchia thus has a double nerve supply as in the ctenidia of the Chitons for example.

The gonad, with the usual characteristice, opens into the pericardium by mans of very short derso-ventrally compressed tubes separated by the alod al. The periendelum is of unusual size, extending hehind the heart nearly to the posterion end of the buty. Is maty be seen Plate 36, fig. 2, it is interupted by the domsal gill retruetors, Jut behind these museles the cavity again beeomes contimums armess the mid line, extending down the rides of the cloalcal eavity (Plate 25, fig. 5) and posteriorly forming a horn-like extension in the mid line. The heart is the usuat tubular organ but posteriorly it mites with an atrum, which may be considered an auricle or an invagination of the ventral pericandial wall continuous pustorioply with the efferent branchial sinus.

The openings of the acomoducts hold the usuat position, at the sides of the supratrectal commissure, but the tulwes with which they communicate are in the limst part of their contro very slender, ciliated, amel somewhat comroluted. In this emelition they extend ventrally and join the glandular portion (Plate 36 , fig. 2). The oells of this seretory portion are of the usual type, almost cubieal racuolated elements containing a small concement. The position of the external opening is shewn (Plate 25, fig. i).

Wiren (92) has accurately dracriberl a patch of ghandular epithelium, a modifieation of the cloacal watl, which on cach side of the body surounds the openings of the gonoulurets and extends to a certain extent over the base of the gills. The colls composing it are high and comsist of very slender supporting cells and glandular clements filled with an almost homogeneous substance, con- 
taining in favorable proparations groups of small primatic crystak. This deseription answers for the present suredes with the cxeeption of the crystals which have not heen found. Wiren rompares this glandular aneal with the shell gland of the Neomeniilate, thongh claiming it ates as an exeretory organ. Begond certain histological resmblandes there are no cogent reasents for arecepting suets a theory.

\section{Chaetoderma erudita, sp. nov.}

Ten speemens of this species wore taken in Lynn Canal, Mlaska (Nita. 4258) at a depth of 300-313 fathoms; and fort y-one were dredged in (hatham strat, Maska (sta. 4264) at a depth of $202-293$ fathoms. In both cases the bottom "onsisted of very tomadous green nud. A number of individuals were kept in an acplarium aboard ship and lived afparently in at normal state, burrowing extensively and in some instances feeding on organic debris. Two males gave off considerable cuantities of sperms during a period of over an hour. It eseaped from the sides of the cloacal cavity, lateral to the gills and soon diffused into the surrounding water, Much care wats taken in the preservation of these anmals, and yet the shrinkage was considerable, in the case of some of the more active ones, anmonting in six individuals to a decrease in the body length of one fourth. It thus bocomes apparent that the length index or latio of length to dianeter is not to be depented on in the discrinnination of species.

The entire animal is represented (Plate 4, tig. 9); the buenal plate (Plate 4, fig. 11), and the spleules (Plate 37, fig. 15). The hypodermis comprises three farly distinct types of eells. Of these the most ennspieuous, in aleohol killed matcrial, is the basal eelt of each spine whose nucleus is placed considerably abowe the lovel of the other types. In material killed in rom Rath's fluid the Roizenzollen of Wiren, well-defined grobular cells, atre very distinct and contain a highly racuolated material which almost totally disappears in allohol killed suecomens. In some cases fibros, probably muscle, attach to these aloments ats in C. attemuata, but their mations are diffieult to detemine. The remaining reflis are simple low columnar elements of the usual appearance.

'The mouth, a relativaly widk opening in the deeply cleft buecal plate, opens into a laterally compresed bueral tube that beneath the brain develops longituclinal folds and a more cirrular outline (Plate 29, fig. 4). As far as the forward end of the radular supports buecal ghands in great abundance are attacher to its watls. The subradular organ is not as sharply defined as in $C$. altcmuata. yet is clearly distinguishable as a median ventral elevation composed of stender 
columnar eells of greater height than these of the adjoining epithelimm. In one specimen killed in rom Ratl's fluid the protoplasm of the component edls is much vacuolated or in a rery small number contains al gramular secretion. Posterior to the rarbla, whose general appearance is sufliciontly shown (l'late 29, fir. s), the pharyux beromes dorso-ventrally compresed, then circular and opens into the stomach. This is a relatively spacions organ with thin unfolded walls that posteriorly beeme thicker and folded. T'le relation of intestine and liver are typical and require no description. In the proximal part of the liver, and throughout the major portion of the intestine, there are eonsiderahle quantities of organic remains, diatoms, sponge spicules, a few fragments of entomostracans, and several chambered Foraminifera whose protoplasm was only partially digested.

The norvous system of this speries is exceptionally clearly defined in one sperimen killed in rom Rath's thuid and for this reason has been more thoroughly studied than any other speries of the genus described in the present paper with the exerption of (". attenuta. The brain is redy distinctly bitobed, a deep indentation occurring on its anterior surface. Fon its lateral and forward borders nerves pass into the preverebral gangliat which in turn sand tremendous bundles of fibres to the buceal sensoly plate. In some speries the comectives to the pedal, lateral, and labio-bucal systems have dist ind origins in the brain, but in the present case they are united for a considerable distance (Plate 13, fig. 3). Each of these rompound comectives alter lowing the bran and passing forward a shert distane gires rise to the labiu-buceal ronnectise and considerably farther on the pedal and lateral coneredives become differentiated. The pedal and lateral ganghia are in the usual poritions and are united by freguent connectives and commistures. It the points of origin of these nerves there are no very dearly defined enlargements thomgh anteriorly the pedat and batral corde are of large size and gradually taper prosterionly, attaining their arerage size atrout the hinder border of the prothorax. As these gandiat

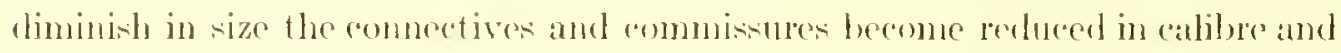
are difficult to follow yot they may be traced bere and these thromghont the entire longth of the animal.

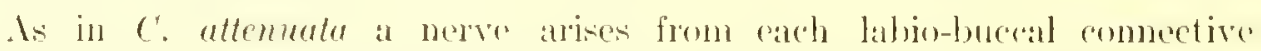
about the lovel of the forward border of the radula and pasing inward and downwart joins a small subratular ganglionic mass. In this species the gunglion shows no indication of heing paired. Each of these subradular connectives gives rise to a nerve distributed to the subradular orgatu and more laterally swells 
somewhat though ganglion colls are lacking. From each of these enlargements a nerve is devoloped, and aftre branching in the pharyngeal musculature beeones lost to riew. This subradubar system does not appear with the diagrammatic "larness of the one in C. attematu, but there is no especial difliculty in determining its relations which are esorentially the same in the two species.

In the posterior regions of the body the nervous system rery alosely resembles that of $r$. attemuata.

The gonal, with the minal rharateristios and relations, opens into the forwatrd end of the perieardium hy meane of comparatively large tubes in sexuatly mature animals. In somo aminnals, possibly owing to killing fluids, the pericardial ravity is greatly distonded with spermatozoa which have made their way into the proximal half of the coclomoducts. These last named tubes commmicate by wide openings with the pericardium and on the other hand extend forward ats riliated tubes for at shost distance. Beyoud this point their walls beeome slandular and ale throun into munerous eonvolutions whide render it inpossible, without nuch elfort, to determine their exact relations. Posteriorly each duct becomes more simple, thomgh of fairly large ealibre, so that it contracts the cavity of the cloaral chamber: and on the ventral border of the fold thus developed the outlet ("amal in formed (Plate 29, fig. 5).

\section{Chaetoderma montereyensis, sp. nus.}

This speeies is evidently alumdant in the deeper waters of Monterey Bay, ('alifornia, as 15 were taken distributed through the following stations: nine

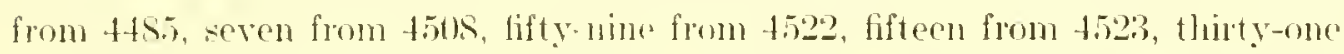
from t52t and thirty-four from t525. In every ase the bottom was mud and the depth varied from 39 to 3.5 (j) fathoms. Chloretone (aceto-chloroform) was used with good results as a narotizing agent and $70 \%$ alcohol served as a fixing agent. The length of a medium sized sperimen' is 45 mm. with an average diameter of $2 \mathrm{~mm}$, through the prothorax and $3 \mathrm{~mm}$. through the preabdomen. The olor in lifo and prespred material is yellowish white.

The hypolermis very aloely rembles that of $C$. attenuato. The spines are represented in Plate 37 , figs: 2, 3.

The month opens through a slit in the subelliption burcal plate (Plate 4. fig. 17) and leads into a latcrally compresod tube which becomes cirroulat in

1 Conerally spesking the largar specimens aome from the shallower depths. This is very marked

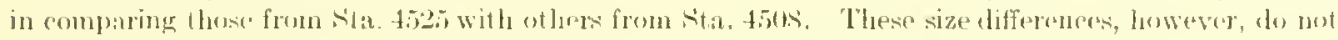

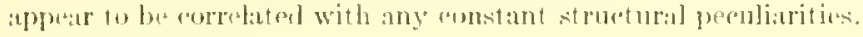


ontline slightly in front of the radula (Plate 27). Throughoul its entire comse to the hinder borders of the radula its walls, more than commonly muscular, afford lodgment for numerous salivary glands whose secretion stains darkly with baematoxylin. The radula, its supports and musculature are typically situated but are exeptionally heavy and powerful. The remaning divisums of the digestive tract are related as usual and are represented on Plate 27. Countless thousands of cliatoms, together with nondeseript organic and inorganic remains, fill the intestine and in some specimens, the stomach.

The perieardium is a comparatively spacious chamber, extending hackwad some distance over the cloacal eavity (Plate 27, fig. 9), and is perforated hy the superior gill rotracters; but otherwise neither it nor the tubular heart and the commecting sinuses are peculiar in suy important particular.

The nervous systom has been studied in comiderable detail, and in all essential respects has been found to resemble that of C. allemalu for example.

The gonad, with the nual chancters, opens into the pericardiun hy eomparatively wide, dorso-ventrally compressed tubses. The immer openings of the coelomoductis are likewise of large size (Plate 27, fig. S) and the adjacent ciliated section also though the latter is musually short. This ciliated seetion unites with a division of the ghandular part (shown on the left, Plate 27, figs. 2, 8). The outlet (Plate 27, fig. 9) oxeus in the customary position and is surroumded by the glandular modifieation of the cloam epithelim as in $C^{\prime}$. attenunta and a few other speries.

\section{Chaetoderma argentea, slu. nuv.}

One specinen (Plate 4, fig. 7) of this epecies was taken in southern Mlaska in the ereen nud of Behm (anal (stat. 423I) at a depth of $82-113$ fathoms. It was in a moribund condition and with the exception of slight morements of the body and gills gatre no signs of life. The mesturements are, fotal length $24 \mathrm{~mm}$. dianner of the prothorax $1.6 \mathrm{~mm}$. White the greatest diameter of the preabdomen was 2.6 mm. The wolor in life and in a preserved state was a silvery white.

The couticle is scant in amount and the hypodermis is amparatively low and is composed of small cedls culical or low eolummar in form. Among these are the giant cells (Reisenzellen) from which the secretion has disappeared but they are attached to faintly staining fibres whose exact relations labe not been determined. The spines are represented (Plate 37, fig. 6).

Nhbough the animal when eaptured was alive it never relaxed suffieiently to allow the bucal sensory plate to become exposed. In sections this last named 
organ appears to be typeal though the glands that open along its margin are more than nsuatly developed. The presadular section of the gut is of average dianeter, fairly musenlar and is provided with numerous glands uncommonty compact except on the dorsal side behind the buain. Violent contraetions of the prothorax lave apparenty been responsible for the dislodgment of the "pithelial lining of this part of the digestive trant; but there are indeations that a subradular organ exists and the nerve smply is distinctly evident. The radula is constructed on the Motul plan as may be seen (Plate 26, fig. 2). Beyond the radula the gut beeomes narow, eircular in section and very soon mites with the "apacious stonach whose relations to the intestine and liver are of the usual type. The stomarh and esperially the intestine contain a comsiderable amount of inerganie and organic material, diatoms loing especially alomdant.

The single specimen is at make with the gemad distended with sex products: in all stages of development. Violent museular contractions have forced a mass of sex cells, many of them immature, into the pericardium; and at various points aloug the coetomodurts fully develoned sperms are present. The reno-perirardial openings, at the level of the posterior borter of the supratrectal commissure, are relatively wirle and lead into correspondingly spacious, highly ciliated tubes whieh pass almost directly ventrally to a point about opposite the mid lateral line where they unite with the glandular portion (Plate 36, fig. 1). This last named section extonds as a slightly convoluted tube to a point about opposite the posterior lordrer of the gonad where it bends sharply upon itself and ventral to the dorsal ciliated section opens into the cluacal chamber at the usual print.

The nervons system shows with distinetuess aml has been traned in considerable detail, but as the results show it to be resentially the same as in $C$. altemente and $C$. crudite it domands no especial description. The subradular ganglion with the usual comnections is clearly a single mass.

Gland colls in the gills are very definitely distributed, in cross sect ions being disposed along the transverse axis of the body (Plate 26, fig. 5).

\section{Chaetoderma scabra, sp. nov.}

One individual was dredged in Monterey Bay, California at a depth of

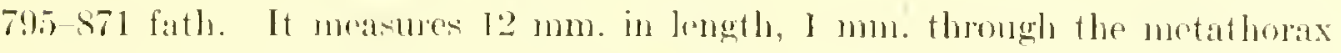
and 2 mm. Through the greatest diamoter of the preabdomen. The expanded pertion of the protherax is light brownish yellow; more posterionly the brown shade is more pronomuced, becoming olive-green in the region of the liver which 
shows through the translucent body wall. An orange-brown substance inerusts the spines about the cloacal opening. The spirules are representod (Plate 37 , fig. 19).

The form of the buceal plate and the position of the mouth oponing are shown (Plate 4, fig. 16). The adjarent soction of the digestive tube rapidly assumes a circular form in section, and a few compact groups of gland cells become appliod to the dorsal, and to a less extent the lateral walls. Immoliately behind the brain these lobules become larger (Plate 30, fig. 3), but soon disappear more posterionly. The radula was cut obliquely and it is therefore somewhat difficult to determine its exaet relations. The tooth appears to be relatively slender, but its suppents and mocmature are typical. Fohind the ladula the pharyon again becomes cirenlar and in this form joins the stomads (Plate 29, fig. 9). This last named organ is at first thin walled, but the epithelimm soon glows higher, becomes folded and soon smooths ont at the lovel of the posterior end of the prothorax (Plate 29, fig. 11). Igain becoming thiek walled and of small calibre it mites with the liver and intestine. From this point onwand these last mentioned organs are of the usmal type.

The periearlial eavity is of more than average size (Plate 29, fig. 10) and the heart is highly museular; otherwise neither these organs nor the connecting sintikes are umusual.

The spereimen is sexully mature and multitudes of sperms have male their way from the gonad through wide tubes into the perieardium and the proximal portion of the coclomoluets. The openings of these later organs into the pericardial cavity are compuratively large and the ducts themselves are relatively simple. As in some other small species the glandular portion is a simple eanal cxtemling as far forward as the posterion end of the gonat where it hends abruptly and making its way posteriorly opens by an incomspiduous pore into the colocal chamber.

The nerrous system is distinct and sharply defined and has been carefully examined, but it does not differ in any important respect from that of $C$. erudita for ixample.

\section{Chaetoderma californica, sp. nov.}

One sperinm was collected in the neighborhood of Sian 1)iego, Califontia, (Nta. 4381) at a depth of 618-66t fathoms. It measures $24 \mathrm{~mm}$. in length hy $1.6 \mathrm{~mm}$., the average thickness of the metathorax, and $2 \mathrm{~mm}$. the arorage diameter of the preabdomen. The general appeatanee of the amimal and the relative length of the valious divisions of the body are shown (Plate 4, fig. (i). The oolor 
of the protrusible portion of the prothorax is yellowish brown, while the remainder of the body is yellowish green. I rusty red substance, possibly excreta, incrusts the spines in the cloacal region.

The cuticle is of moderate thickness and rests upon a hypodermal layer whose nuclei, placed at various levels in the region of the prothorax, have at first sight the appearance of being more than one cell thick. The most common type of cell is reiatively slender and eontains an oval granular nucleus. Among these are other elements, probably spicule matrix cells, each of which contains a spherical nucleus larger in size than those of the foregoing class of cells and placed in the neighborhood of the base of a spine above the general level of the hypodermis. As in C. attemata spaces exist at frequent intervals in the hypodermis and from the vieinity of each fibres pass into the underlying museular layer. As noted on page 5.5 there are reasols for the belief that these are gland cells, of unknown function, whose secretion is dissolved through the ageney of alcohol when used as a fixing agent. The shape of the spines is shown (Plate 37 , fig. 14).

The alimentary eanal opens through the dorsal half of the buceal plate; its first section (Plate 27) is a narrow canal that rapidly widens in the neighborhood of the brain. To its liming epithelium the usual muscles attach and afford lodgment for numerous buecal glands. These last named organs extend from the mouth to the level of the brain and are similar to those of C. nitidulum save that the cells are less compact and of larger size. In the neighborhood of the radula the walls of the pharnx becone more folded than in C. nitidulum and are unicue in possessing a pouch (Plate 31, fig. 8) of considerable extent, into which the glands of the dorsal side open. Behind the radula the canal gradually nalrows, its folds become smoothed out wherempon it unites with the stomach.

The salivary glands consist of several globular cells surromding a small lumen that in some instances is in direct communieation with the digestive tract. However each eell communieates with a small durtule which gives evidence, not of passing the secretion into the lumen of the gland, but directly into the digestive tract through interecllular channels of the lining epithelium.

The radula presents no expecially noteworthy features. Its conical tooth is slightly more slender than is usual (Plate 31, fig. 1), hut the cuticular winglike supports and musculature are entirely typical.

As usual the pharynx opens by a comparatively narow pore (Plate 31, fig. 2) into the stomach whose relations to the liver and intestine are normal. Large quantities of organic remains ocenr in the gut, Radiolaria, diatoms, and sponge 
spicules being distinguishable. Associated with these are numerous rounded cells (Plate 35, fig. II) that occur also in the digestive gland. In most cases these are free but oceasionally one may be scen that is encysted in the cells of the organs mentioned. Rarely they are associated in pairs as though in the process of conjugation.

The gonad holds the usual position and like the sperms, in all stages of development, presents no noteworthy characters. Posteriorly the halves of the organ diverge, beeome rather indistinet though their route may be traeed with certainty, owing to the presence of spermatozoa, passing lateral to the heart or the expanded base of the aorta and opening into the perieardium. This last named space lacks the almost diagrammatic outline as in C. nitidulum and is much more limited in extent, but its relations to the gonoduets are very similas.

\section{Chaetoderma nanula, sp. nov.}

One specimen of this species was dredged off the coast of southern California (Nta. 4369) at a depth of 260-284 faths. It is $9 \mathrm{~mm}$. in length by 0.9 and 1.2 the average diameter of the metathorax and preabdomen respectively (Plate 4 , fig. I). The color of the globular, protrusible portion of the prothorax is light brownish yellow (though this may have been produed by tamnin from the cork), while the metathorax and preabdomen are considerably darker, the latter region becoming olive-green. A dark brownish substanee inerusts the spines about the cloacal opening. The hypodermal layer is comparatively thin, the cells small and somewhat indistinct, yet are typieal so far as may be determined. The spines are represented (Plate 37 , fig. IS).

The mouth opening represented (Plate 4, fig. I2), leads into a relatively spacious tube lined with slender columnar cells except along the dorsal side where they are almost eubieal. A median fold, located immediately in front of the radula, probably represents a subradular organ since it is typically innervated. Sillivary glands are ahnost wholly lacking, a small group attached to the pharyngeal wall adjacent to the radula being all that is visible in the present speeimen. The radula is small but typical. Beyond it the tube narrows considerably, the lining becomes folded and in this form it unites with the stomach. At the outset this last named organ is plain walled but near its union with the livel beeomes eonsiderably sacculated. The intestine is distended with fragments of Radiolaria, sponge spieules, and organie debris. Parasitic Protozoa, resembling those from Chactodema californica, are abundant and are imbedded in the epithelial lining of the stomach, intestine, and liver throughout their entire extent. 
The animal is a female, not perfeetly mature, and the duets leading into the perieardium are accordingly small. The openings into the roelomoducts are likewise minute, and the ciliated tube with which each connects is relatively long and slender. The glandular division with which it unites is a comparatively simple tube, at first directed forward until it reaches the level of the front end of the heart whereupon it bends abruptly and makes its way to the opening inte the cloacal chamber (Plate 28, fig. 10).

The nervous system is in an exeellent state of preservation and is clearly defined, but a careful study las failed to disclose any noteworthy feature. It may be mentioned that a subradular system exists sinilar in all respects to that of C. atteruata.

\section{Chaetoderma japonica, sp. nov.}

One specimen (Plate 3, fig. 7) was dredged off Honshu Island, Japan (Oi Gawa, sta. 3721) at a depth of $207-250$ fatloms. The body is comparatively slender, measuring $17 \mathrm{~mm}$. in length by $1.3 \mathrm{~mm}$. through the metathorax and $1.5 \mathrm{~mm}$. through the preablomen. The eolor is almost white with a slight tinge of yellow. I slight incrustation, brick-red in color eovers the spines in the eloacal region. The spines are of the usual type.

The moutl opens through a distinet pore in the buceal plate (Plate 3, fig. S) which, like the neighboring section of the digestive tube, is abundantly supplied with glands, small celled and more than commonly compact. These continue, for a considerable distance behind the radula, apparently unchanged in eharacter though in many cases elosely applied against the bases of the buceal and pharyngeal epithelium. This first named organ with its supports and museulature is typieal, as may be seen in Plates 30,31 . As the major portion of the body was not seetioned the mion of liver and stomach has not been seen; otherwise these organs conform to the usual plan. The prerectal portion of the intestine is lined with an exceptionally high epithelinm so that the lumen is very small where it is not distended with pellots of faceal matter comsisting principally of diatoms and sponge spicules.

The nerrous system is not experially favorable for study and aceordingly only its more general features have been examined. In this respeet it is trpieal.

The specimen is a female and the fully formed ova present the customany appearance and are developed in a gland holding the usual position. The ducts leading into the pericardium, are large and as in the "use of thr last named space, and the gonoduets, are filled witl eggs mostly disintegrated, due perhaps to violent movements of the somatic museulature. The gonoducts open by relat 
tively large pores into the pericardium and as moderately spacious tubes without any marked convolutions, extend to their openings into the cloaca (Plate 30, fig. 7). Surrounding these pores the eloacal epithelium is modified to form the glandular area sinilar to that of $C$. attenuata.

Chaetoderma robusta, sp. nov.

Four speeimens of this species were taken south of the Alaskan peninsula (Sta. 3210) in green mud at a lepth of 483 futhoms. The largest specimen (Plate 4, fig. 5) is $60 \mathrm{~mm}$. long with an average cliameter through the metathorax and prealudomen of 3.5 and $4.7 \mathrm{~mm}$. respectively. The smallest is $35 \mathrm{~mm}$. long with an average metathorax diancter of $2 \mathrm{~mm}$. and 3 through the preabdomen. Where the spines have not been disloclged the general color of the body is slaty gray shading to buff at the anterior end of the body. A yellowish brown substane incruts the spines about the cloara.

The hypodermis consists of numerous small cells rather closely crowded so that the cells lack distinctness. Howerer giant cells are visible and faint fibres, connertive tistue or musele, springing from the underlying body wall appear to attach to them. Spienle-matrix cells in all stages of development are visible, and in each catse the spines are attarhed to mly one coll so far as it is possible to judge. The remaining clements are comparatively slender, compact and lack any noteworthy features. The spimes are represented in Plate 37, fig. 4.

The buecal plate is shicld-shaped in outline (l'late 4, fig. 19), and is piereed by the mouth opening. The buceal and pharyngeal cavities are slencler, and the walls of more than average thickness (Plate 30). The lining cells are aceordingly very slender, ciliated and are thrown into a few prominent folds. The ductules of a very large number of salivary glands make their way between the cells and in some eases are in the aret of pouring their secretion into the eanal. A subradular system is present, and as usual two nerves are distributed to a median fold of tharyngeal epithelium that probably functions as a subradular organ. However with the exception of affording scarecly any outlet for the salivary glands its cells are not clearly distinguishable from the general epithelium. The radula consists of the usual conical tooth, rather heavier than usual, but with supports and musculature of the eustomary type. Beyond the radula the traet becomes circular in ars scetion before uniting with the stomach whose relations to the liver and intestine are typical.

The circulatory system presents no noteworthy features beyond the fact that the heart is suspended by a fold of the perieardial wall reinforeed by a few 
eomective-tissue fibres, and is sumounded by a periearelial cavity that posteriorty extends as a slit-like space between the cloncal and body walls far along toward the posterior end of the body.

In its general features the servour system closely resembles that of $C^{r}$. crudita and $C$. attemuata. The labio-buceal system has been worked out in detail, but it is no exeeption to the statement just made.

The gonad is of large size and is distended with spermatozoa that have made their way through wide canals into the pericardium. As ustul the perieardial openings are situated close to the suprareetal commissure, and bath into clearly defined ciliated duets which very soon unite with the glandular portion. In this speeies the glandular portion is at first relatively slender, and but little convoluted yet it soon enlarges greatly, becomes much folded and extends as may be seen in Plate 30, figs. 5, 7, from the posterior limit of the gonad to its opening into the cloacal eavity.

\section{Limifossor talpoideus HEATH.}

Zool. Anz., 1904, 5, p. 2S. Zool. Jahrb. Abth. Anat. Ontog., 1905, 5, p. 21.

Several specimens of this species were taken in Mlaska in the Lynn Canal (Sta. 4258) and in Chatham strait (Sta. 4264) at depths ranging from 282-313 fathoms. The general appentunce of these animals is shown (late 10, fig. 1). The length ranges from 6-12 $\mathrm{mm}$. and the diameter from $1-2 \mathrm{~mm}$., the ratio 1: 6 being constant.

The mouth, almost terminal in position, is bounded by the sensory plates (Mundsehild) and more dorwally by the type of spine covering the prothorax generally. The plates in life molergo rapid changes in form, but histologieally and in their imervation they resemble their homologue in Chaetolema. The deep semicircular groove (halbmondfömige (irube) situated beneath the mouth and sensory plates, is lined throughout with the spiculose integument of the body. The spines are triangular or leaf-like and lange in length from $0.02 \mathrm{~mm}$. in the region of the mouth to those about the cloacal chamber $0.38 \mathrm{~mm}$. long.

The hrpodermis is relatively very thin, the boundaries of the cells indistinct and similar in general to that of other species of Chactotema. The somatie museulature likewise is very similar in the two genera.

The mouth leads into a comparatively narmw eanal with bongitudinal folds covered with a well-defined cuticle. In the region of the radula the canal enlarges, develops a subradular pocket (Plate 10, fig. 4) and dorsally continues as a circular tube to its junction with the stomach. Attached to a dorsal diverticulum numerous cells pour their seeretion into the pharynx. A clearly defined subradu- 
latr organ does not exist and yet the fact that in the mid line the cells ane more than usually high and slender and are in close proximity to nerves from the labiobuecal ganglia indieates that the area excreises a sensory function. The radula and its supports and attendant musculature are enormously developed and indicate active predatory habits, but in every case the alinentary canal contains little besides a few diatoms, sponge spicules, and a small quantity of inorganic detritus. The radula with twenty-eight transverse rows is of the distichous type (Plate $\mathbf{3 4}$ figs. 3,6$)$, the long claw-like teeth being united while in the radula sheath by a clearly defined basement membrane. When freely cxposed this membrane splits along the mid line and the teeth become located on each side of a deep cleft in the forward end of the radular supports (Plate 10, fig. 10). Odontoblasts, in typical fashion, form the tecth which are subsequently enveloped by numerous enamel cells.

The radular supports comprise two great masses of muscle and connective tissue which together form an ovoid mass grooved dorsally to hold the radula tube. To these numerous museles attach that are in part responsible for the movements of the tecth. I detailed description of these and other muscle bands has been given in another place (Heath '05) and an attempt has been made to determine their functions.

The stomach is sharply differentiated from the remainder of the digestive tract (Plate 10, fig. 4) and oecupies practically all of the space between the end of the radular supports and the forward border of the gonad and digestive gland. Its epithelial lining is produced into a number of heavy folds that gradually blend with those of the ocsophagus. In most cascs the intestine leaves the posterior end of the stmach in the mid line, and immediately ventral to this union the hiver opens by a single pore. This last named organ is relatively voluminous, filling much of the space beneath the gonad between the stomach and forward cloacal wall where it ends blindly. The intestine, of practically the same calibre throughout, makes its way by a fairly direet route to the front end of the pericardium. Here it bends abruptly downward and passing under the cloacal wall opens to the exteriol in the mid line.

A clearly defined connective-tissue septum bounds the head carity posteriorly as in the Chitons. It passes immediately behind the radular supports and is penetrated by the alimentary canal, dorsal aorta, and pedal simus.

The pericardial eavity is of trihedral form and encloses a tubular and more than usually museular heart without any distinet subdivisions. The aorta passes out from its forward border, and as a distinct tube with definite walls 
makes its way between the halves of the gonid to an opening in the septum bounding the head cavity. This latter space communicates with a well-defined pedal simus, which perforates the septum and pursues its eourse posteriorly, communieating lere and there with the general viseeral eavity, to the neighlorhood of the cloaeal eavity. Here both sinuses unite on their way to the gills from which the blood passes above the dorsal gill retractor to enter the heart.

The brain, elearly bilobed, develops filores which unite with five pairs of preecrebral ganglia that in turn give rise to nerves passing to the sensory plate. The lateral, pedal, and labio-buceal connectives unite before entering the luam. The last named are first to be differentiated and holding the usual position at the sides of the pharynx, they unite with the ganglia lateral to the dorsal salivary glands. These nerve masses are united by the usual commissure and by another passing dorsal to the pharyx in the neighborliood of the salivary glands. What appears to be a complete one passes ventrally into the neighborhood of the subradular organ. A nerve from each ganglion passes backward and probably innervates a portion of the digestive tract. The lateral and pedal ganglia, with the wsul relations, extend to the region of the eloaea where they unite to form on each side a well-defined enlargement conneeted by a suprarectal commissure. From each swelling several nerves arise that are distributed to the cloacal and body walls; while from the commiswure branches are developed, dorsally and ventrally, that imnervate the etenidi:t.

The gonad extends from the stomeh to the perieardial eavity into which it opens by relatively long and slender duets. The eoelomoducts have the form of simple tubes extending from the pericardium to separate exits in the eloacal ehamber. Their inner openings are situated in the infero-lateral angles of the perieardial eavity and are guarded by high prriform cells devoid of eilia. On the other hand the succeding portion of the canal, of very small calibre, is composed of cubical elements covered with a heary eiliated coat. This division makes its way forward to the outside of the dorsal gill retractor and mites abruptly with the glandular portion, which although a single tube is so ronvoluted that it beeomes a relatively voluminous structure. Its watls are composed of more or less eubical cells of which the cytoplasm is scant in amount owing to the presence of one or two great vacuoles. The general structure bears a fairly close resemblance to eertain kidney tissue yet there is no positive proof that it possesses an excretory function. The outer openings are on each side of the amus a short distance anterior to it, and though very minute in preserved material they are nevertheless clearly defined. 
Limifossor fratula, s]. nov.

This species is represented by two individuals taken off the coast of southem California (Ntat. 4369) at a depth of 260-2st fathoms. In general it so closely resembles the foregroing species that a very brief deseription will suffice. The body, slity griy in color with a slight yellowish cast, is shorter and thicker than in L. tulpmideus, and owing to a hearier body wall is much firmer. The spines of the two species are very similar in form, but in the present species they are of considerably latree size. Spicules from the middle of the body are $0.5 \mathrm{~mm}$. in longth while in $I_{\text {. }}$ talpoidens the largest of the body do not exeeed $0.38 \mathrm{~mm}$. The bypodermis is also proportionately thick and what are probably matrix cells are froquent and sharply differentiated from the other elements of the hypodemis, and hence different from $L$. talpoideus in this respect.

The digestive tract in the two species is, neglecting minor differences, built upon the same plan. Heary as is the radula and its supports in L. talpoideus it is even heavier in the present case, and the teeth are of larger size, making it so difficult to section them that at present there are no clear indications of their exact shape though it appears certain that the smaller cusp of each tooth is larger than in the preceding species. The muscles that operate the radula are typical but are unusually heary.

The nervous, circulatory, and reproductive systems are very similar in the two species.

This species is readily distinguished from the foregoing by the size of the spines, the structure of the hypodermis, and the heavier musculature and consequent firmuess of the body.

Pachymenia abyssorum, sp. nov.

One specimen of this species was drelged off the southern coast of California (Sta. 4397) in 2196-222s fathons, the greatest depth recorded for any solenogastre. In bringing the animal to the surface the consequent decrease in pressure upon the borly resulted in the active release of gases from the blood, causing the displacement of the cuticle to a considerable extent, the shrinkage of the hypockermal cells and the partial destruction of the foot at various points; otherwise the tissues are in a good state of preservation. The body is thiek set, externally resembling Alcxandromenia valida, and measures $27 \mathrm{~mm}$. in length by $4.5 \mathrm{~mm}$. average thiekness. The color in a light yellowish white. As is indicated (Plate 39, fig. 4), the foot is exposed for it considerable distance, and is unusually broad and doubtless in life is capable of forming a relatively large 
surface possibly enabling the animal to crawl about on the bottem ooze. As in the ease of Alexamdromenial this individual is mattached and maly be aceorelingly a roving form.

The euticle is approximately three times the thickness of the hypodernis, but is seant in amount owing to the vast mmmbers of necrle-like spicules, of varying sizes, imbedded in it. Is noted above the hypodermal layer is not in a good state of preservation, but it may readily be discovered that the cells are unusually slender, and laterally and ventrally form papillae in the head region. There are low elevations at other points over the hody but it is not certain that they are definite papillae.

The external opening of the anterior pedal gland is a cavity of large size whose walls atre provided with folds of unustal height. On the posterior wall these are approximately seven in number, the outermost on ald side being very large. Behind the cavity the five included folds disappear while the large lateral ones unite in the formation of a foot with a creeping surface of greater width than in any other known species of Solenogastre. In the posterior end of the body the foot decreases in size and becomes continuous with small folds of the eloacal wall.

The anterior pedal gland is a voluminous organ lying at the sides of the body opposite the extemal outlet. The cells composing it ane execptionally small but otherwise present no noteworthy characters. Behind it shades into the posterior pedal gland without any appreciable change in the character of the cells. Throughout the entire extent of the foot the gland is unusually large and the ductules appear to open over the entire ereeping surface.

The extemal atrial opening is subteminal and large, and leads into the customary cavity provided with ridges and cirri typically situated. As may be seen in Plate 39, fig. 1, the external ridge is continuous across the mid line in front of the external opening of the atrium and though relatively small at this point it rapidly increases in height, finally becoming of such a size that it may be seen in external view. The inner ridge is likewise small anteriorly but behind becomes as extenive as the external fold. Bohind these two folds are continuous with each other and are romnected with several long plaits in the hypodemis which extend to the external opening of the pedal gland. The cirri are simple unbranched processes, slightly pigmented and contain a muscle or nerve fibre extending, in some cases at least, thronghont their entire extent.

The atrium communicates dorsally with the succeding section of the digestive tract whose general relations may be determined from an examination 
of Plate 39, figs. 1, i. The walls of this division are provided with numerous muscle bundles of irregula distribution between which are multitules of glands staining actively when treated with Delafied's hamatoxylin. The cells composing these glands are without distinct cell boundaries, are made up of vacuolited protoplasm contaning droplets of various sizes and are grouped into lobules of various bulk. In many places they extend into the folds of the epithelial lining of the pharynx and give evidene of opening though intereellular (diannels.

Some distance toward the dorsal side of the animal a fold of large size appears in the wall of the digestive tract which narows the pharyngeal cavity to a relatively small tube. At this point the epithelial lining becomes thicker, a character which it retains to the stomach-intestine, and the walls become surrounded by a heavy sheath of eireular muscles to which vast number of gland rells at tach. These gland cells are grouped into slenter lobules, and owing to the fact that they are much vacuolated their tint is fainter than in the case of those of the preceding division of the tract. The nuclei also are of larger size and more distinct, but the secretion presents the same general appearance. A sender duet on each side of the pharynx (Plate 40, fig. (i) extend from the region of the ventral labio-buceal commisure (Plate 39, fig. S), to its outlet (Plate 39, fig. (i). Posteriorly each ends blindly and anteriorly is provided, as in the case of Nexandromenia, with a papilla which is doubtless capable of being protruded into the pharyngeal cavity. Throughout its entire extent the duetules from these glands attach to the canal, but behind it they connect with intercellular channels and so pour their secretion direetly into the pharyngeal avity. The glands with this last named outlet present the same appearance as those communicating with the ducts exeept in the neighborhood of the stomach-intestine where they become more compact.

No trace of a radula or radula sac exists.

The pharynx or oesophagus projects for a great distance into the stomachintestine which is provided with several longitudinal idges instead of the customary saceulations. The middle portion of the body was not sectioned but as these ridges are present in the posterior end of the animal it is probable that they extend throughout the entire length of the gut. Many of these folds contain blood sinuses which often produce a marked distention. The lining cpithelium is composed of more than usually slender cells many of which contain more or less spherical, granular masses. Posteriorly the intestine narrows, passes between the coelomoducts and opens into the cloacal chamber. No 
traces of food were found in the tract and acoordingly we are without any knowledge of the animal's feeding habits.

The walls of the eloat chamber are provided with a number of slender outpouchings and to these are attarhed multitudes of gand cells grouped into lobules of different sizes. Fach cell is pyriform and contains a somewhat eranular slightly vacuolated secretion that makes its way by a delicate ductule through an intereellular opening into a diverticulum of the cloacal wall. The general arrangement of these struetures is shown in Plate 39, fig. 2.

The pericardial cavity is comparatively spacious and the contained heart, consisting of two divisions, is moderately muscular. The aorta in the present speeimen is of small size but in its relations to the gonad and the anterior end of the body it is typical. Owing probably to the size of the foot the ventral sinus is large and comnects in the usual fashion with the head sinuses and here and there throughout the body with the viseeral sinus. In the posterior part of the body it divides, passes dorsally on cach side of the intestine and after passing posteriorly for a short distance breaks up into a small number of lacumae which connect with the gills. From these organs the blood pakses through rather ill-defined chamels in the somatie musculature to the posterior end of the heart.

Five or six pairs of relatively large folds appear in the cloaeal wall ruming more or less parallel to the outer opening near which they are situated (Plate 39 , fig. 2). Here and there these develop numerous minor wrinkles (Plate 40, fig. 7) which pass from one main fold to another or extend some distance over the cloaeal wall. As usual they all contain blood sinuses but otherwise are not especially modified.

The brain, imbedded in the numerous glands attached to the forward wall of the pharynx, is an unusually elongated structure and witlout distinet signs of being bilobed. From its anterior face the usual nerves, heavy in appearance, are distributed to the body wall and the ganglionic masses about the bases of the eirri. The lateral, pedal, and labio-buceal comnectives arise from the extreme lateral boundarjes of the brain and follow the usual eoure. A very slight enlargement masks the point of union of the lateral ganglion with the eorresponding connective, while one of twice the diameter occurs in the case of the pedal cords. The last named structures are united at fairly definite intervals by elearly defined commissures and about the same number of connectives attach to the lateral ganglia. A nerve from the anterior pedal enlargement passes to the wall of the outlet of the anterior pedal gland, and two branches originate from a corresponding point on the lateral ganglia and applied to the 
somatic musenlature extend fan forward into the anterior and of the body. The

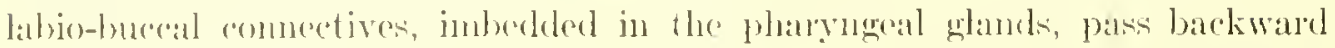
about bull the length of the pharyn where they join the ventrally placed ganglia (Plate 39, fig. S). These masses are in turn united by a strong commissure provided in its nid section with several ganglion cells from which a nerve arises and rextends backward for a considemble distance attached to the pharygeal glands. What apporats to be at dorsal commiswe springe from the upper side of the ganglia, passes dorsally and may be traced here and there amid the glands over the dorsal surface of the pharynx. It has not been followed throughout its contire extent yet I have but little doubt that it is a definite commisure. From the posterior borders of carch labio-bucent ganglion a nerve arises and imbedded also in the glands of the pharynx extendis for a ronsiderable distance posterionly before it beemes lost to viow. Finally it may be said that the arrangenent of the hrain and anterior portion of the nervous system is more regular than in the case of Alexandromenia for example, but otherwise there is no fundanental difference.

In the posterior end of the body the pedal ganglia continue to be united by commissures of large size and pratedially the same number of comnectives unite them with the lateral ganglia plated high up on the sides of the body. In front of the anterior eloaral wall the pedal conds bend dorsally and provided throughout with ganglion colls attach to the lateral nerve masses at the sides of the peri(ardial cavity (Plate 40, fig. 4). From the posterion end of the latral and pedal ganglia nerves arise and extend backward along the body wall and in some places pass into the closical folds.

A well-defined dorsal sense organ is present whowe location is represented (Plate 39, fig. 2). Owing to the fanct that it is of small size, that the cells like those of the hypodermis are not well preserved and beranse of the obligue direction of the seetions its strueture has not been aleeurately deternined ret so far as the examination las gone it appears to conform to the usual type.

The ovo-testis oreupies the ninal position on the dorsal side of the animal and extends forward to the pusterior and of the pharyn. The ova are unusually large and are surrounded by a chorion, lut with these exceptions neither they nor the spermatozor presont any expecially noteworthy features. The duets leading from the gonad into the pericatrium are of comparatively large aralibre.

In several resperets the eochomolucts are remarkable structures and unlike those of any other known solenogust re. In the vicinity of their inner openings 
the perieardial wall becomes thickened and mumerous small folds appear which converge and in some cases at least become continuous with the adjacent seetion of the duct. A short distance beyond the perjoardial ravity and as far distally as the seminal receptacle each duct affords attachment for a vast number of glands of unknown function. These are slender divertionla (Plate 40 , fig. 2), composed of rery small cells with indistinet houndaries filled with a fincly granular faintly staining secretion. In the present specimen large cuantities of spematozoa are present in the coelomoducts and frecpuently these have made their way into some of the diverticula where they form mases without definite arrangement. Whether this is a normal oecurrence or a post mortem effect camot be definitrly decided with the matcrial in hand. Beyond these glands the dorsal seetion of the coclomoduct beemes thin walled, without folds and soon joins the ventral divisjon which as Plate 39, fig. 2, indicates is of large size, thin walled, with fow folds and is crowded with sperms. Immediately ventral to the union of the dorsal and rentral limb of each duct there is a small globular outpouching to whowe internal wall largo numbers of spermatozon are attached so that in poxition and function it is to be considered as a seminal reeptacle. Sperms with the same mode of attachment are found in considerable numbers adjacent to the seminal receptacles and rarely at much greater distances, even as far as the undivided section or shell gland. The cavity of this last named organ is not much litrger than that of the dorsal section and its epithelial lining is relatively thin but a multitude of glands, attached throughout its entire extent, give it a heary appearance. There glands are composed of compact, pear-shaped cells arranged in lobules that open by intercellular channels in the epithelial lining of the shell gland. As may be seen in Plate 39, fig. 2, the shell gland pushes inward the anterior wall of the cloacal chamber so that its outlet is far within this last named carity.

\section{Drepanomenia vampyrella, sis. now.}

This speciss is represented by a single specimen dredged off the southern coast of Oahu lsland (sta. 3907) at al depth of 304-315 fath., where the temperature was 43.7 F. It was coiled tightly about a solitary poly? of Epizoanthus, and further examination showed that the proboscis of the molluse was protruded through the body wall of the coelenterate, whose reproductive and other tissues had been drawn into the alimentary canal of its captor. There is therefore no doubt that this species is earnivorous and that its association with the actinian is not an aceidental one or a case of commensalism. 
The body (Plate 2, fig. 2) measured 9 mm. in length, was slightly compressed laterally, particularly its anterior half, and in form was somewhat spindle shaped, being largest about the middle section of the body and gradually tapering off toward each end, apecially posteriorly where the body becomes quite slender before terminating in a truneated extremity. A well-defined keel extends along the entire animal in the mid dorsal line. The color was faint yellowish white.

The cuticle surrounding the body is of medium thickness, measuring 0.35 $\mathrm{mm}$. in the keel and $0.28 \mathrm{~mm}$. elsewhere in the dorsal region, but gradually decreasing to half this amount on the rentral surface. It includes a single layer of radially directed spicules (Plate 32, fig. 6), ranging in size from those in the first stages of formation to others of the keel $0.129 \mathrm{~mm}$. long. All are of the same general form represented in Plate 37 , fig. 7 . It is to be noted that many of the spicules are not in contact with the hypodermis, even the matrix cells having disappeared, but are situated far out toward the surface of the body. Bencash each developing spine are several cells apparently instrimental in its formation.

The cells of the hypodemis are very small and indistinct and aceordingly have been examined only superficially. The prevailing eells are slender with subeentral muclei, and are develnped into numerous small elevations, some of which comnect by strunds with the overlying papillae (Plate 32, fig. 6). These last named organs contain upwards of eight cells in the enlarged portion; none appear to exist in the exceedingly slender stalk.

As in other species of the family the ventral furrow commences elose to the hinder border of the lip, and extending the entire length of the animal becomes continuous with the cloacal opening. Anteriorly it contains a relatively deep exeavation into which the anteriol perlal gland opens by the usual numerous interedlular ducts. This last naned gland occupies practically all of the visceral cavity between the region of the brain and the anterior end of the gonad. The cells composing it are genorally prriform, with an average diameter of $.021 \mathrm{~mm}$. and a 1 re filled, save for the small compaet nuclei, with a finely gramular substance that stains intensely with logwood dyes. In some cases this secretion appears to be undergoing solutiom, and presents a vacuolated appearance, a character that is very pronouned among the cells of the posterior pedal gland. These latter elements are related also to the foregoing in general form, size, and appenrance, and extending to the cloacia and opening on each side of the foot, are thus secn to hold the usual position.

At the hinder border of the erypt into whieh the anterior pedal gland opens, 
the foot arises as a single, small prominence and rapidly assumes its fully developed condition. Posteriorly it gradually decreases in size, disappearing, so far as may be judged from longitudinal scetions, at a point immediately in front of the gonoduet openings.

The general relations of the anterior section of the digestive tract are fully represented in Plate 7 , fig. 4 . As will be seen the atrial opening is subterminal in position and of medium size. The relations of the succeeding parts, while much the same as in l'roneomenia, for example, are somewhat obscured by the protrusion of the pharyn. An outer ridge, composed of the usual type of columnar cell though apparently lacking eilia (Numdleist), is present. The inner ridge, probably related as in other species, has in the present specimen been carried out on the tip of the pharynx, an interesting fact as it indicates that these cells may be sensory, and of service in determining the character of the animal's food or surroundings. Between these two prominences the usual cirrose area is present, the cirri being of relatively large size and umbranched. It has been suggested that the cirri, secreting a viscous material, may serve in the capture and retention of food. Here, however, is an animal killed in the aet of feeding with its proboseis penetrating its host. The material drawn into the pharynx does not come into contact with the cirri, which in this case must eertainly have some other function, though it is difficult to say what this may be.

In its present extended condition the pharynx is relatively slender, almost wholly devoid of longitudinal folds and is relatively muscular. Heavy retractor muscles attach to the buccal wall and serve to withdraw the pharynx, that appears to lack special retractors of its own. In some species of Neomenia the ventral sulivary glands are described as being more or less eoiled; in the present species this would probably be the ease, but with the protrusion of the pharyon their opening into the anal have been carried forward until they are very close to the end of the proboseis. Each gland is unbranched, composed of excessively spongy cells and is possessed of a relatively large lumen, and a length of fully one fouth that of the body. In view of the fact that Drepanomenia has 110 radula it appears probable that the salivary secretion exereises a solvent action on the tissues of its victim, and the liquified material is then sucked in. The digestive tract in the prevent case is well filled with a finely granular substance in which one may recognize here and there the remains of cells, ehiefly reproductive, belonging to its host.

As may be seen (Plate 7, fig. 4), the stomach-intestine extends forward a considerable distance in front of its union with the pharynx, thus forming an 
extensive anterior coceum. On this sack a number of short outgrowth are developed chiefly on the dorsal side. A short distance behind the front end of the gonad gut ponches appear arranged with great regularity, and from this point on digestive aells attain their fully developed condition. In the region of the pericardium the salculations valish, the canal narrows rapidly and the liver cells are replared by low colummar colls thrown up into longitudinal ridges extending to the opening into the eloaeal chamber.

In this specimen the perieardial cavity is relatively large (Plate 6, fig. 3), and the heart it contains is eonsiderably distended with blood, rendering it possible to some extent to determine the eourse of the circulation. The blood returning from the gills, and another smalles portion that appears to come directly from the himder portions of the body, pours into a well-defined auricle situited at the linder end of the pericandial carity beneath the ventricle. Its walls are only slightly lesis muscular than those of the ventricle, and owing posibly to musenlar contractions, are dereloped into several pouches that do not bave the appearance of blood glands. From the auricle the blood passes into the ventricle thomgh a comparatively large opening guarded by a welldeveloped nutucular flap probably functioning as a valre.

From the fromt end of the ventricle a clearly defined vessel arises, and passing forward unites with the dorsal aorta. This latter vessel holds its usual position between the body will and gonad, but it extends backward over the dorsal sicle of the pericardium as far as the posterios end of the ventricle. Anteriorly the relations of the veswels in the gonad and of the aorta to the head eavity are escentially as they are in P. havaichsis. This appears to be the ease also with the sinuses in other parts of the body, though using longitudinal seetions through the somewhat twisted body, it is not possible without mueh labor, to determine their comnections acemately.

With the protrusion of the pharym the brain has been carried some distance ventrally, but under ordinary cireumstances its position and the relations of the nerves which it develops are probably not unusual. As Plate 7, fig. 4, shows three pairs of nerves pass to the atrial wall as in other of the Neomenima, and are probably destined, here as there, to supply the cirri, anterior musculature, and hypodemnal sense organs. So far as may be judged from sections, the labio-buecal comnectives originate some distance from the pedal and pallial, and may be dearly seen to past down to ganglia situated on the sides of the pharyx where it unites with the buecal wall. From the hinder border of each ganglion a fibre originates that nay be the inferion or ventral commisure, but 
owing to innumerable muscles it was not possible to determine this conclusively. Neither was it possible on this aceount to deternine if any subradular system exists.

The relations of the pedal and lateral ganglia call for few speeial remarks. In some places it was posible to demonstrate pedal commisures, and to trace conneetives between the pedal and lateral cords, especially in the hinder regions of the animal where the eords are closer together. The most posterior connective is especially heavy (Plate 11, fig. 1), and develops two or three fibres whose branches may be traced to the musculature of the body wall. On the inside a very few exceedingly delicate nerves pass to the terminal section of the coelomoducts. From the posterior swollen section of the lateral cords (ganglion superior posticus) several nerves arise ehiefly distributed to the body wall. The dorsal commissure is relatively heary and closely applied to the dorsal wall of the rectum. In the median line it gives rise to a nerve that may be traced to a point near the dorso-teminal portion of the body. In position it eorresponds to the nerve supplying the dorsal sense organ in otber Solenogastres deseribed in this paper, but no such well-defined sensory area appears to be present in this species.

In this speeies the paired gonad, without any speeial peculiarities, terminates rather abruptly at a point about as far forward as the himler border of the atrial opening, and on the other hand pases by two relatively large duets into the spacions perieardial chamber (Plate 11, fig. 1). From the lateral portions of a small recess at the posterior end of this cavity each coelomoduct arises, and after pasing downward for a short distance then passes forward, gradually inereasing in size unt il it reaches a position abont level with the hinder tip of the gonad. Here it hends abruptly and coursing hatckward mites with the one of the opposite side, and as a short common duct makes its way to the eloaea.

Fach canal commenees its eoure with an epithelial lining escentially like that of the pericardial wall, being composed of low flat eells entirely devoid of cilia and lateral cell boundaries. These deficiencies are soon overcome, however, and there are cridences in some of the cells a short distance from the perieardium of a slight glandular activity. In proportion to the increasing diameter of the duct the cells show a greater width and height and the cilia become a strongly marked feature. This holls true for only a portion of the canal however for at a point slightly below the level of the lateral nerve the eharacter of the liming changes abruptly. At this point the cells become high and columnar along the dorsal side of the tube and form a ridge, extending forward to the most anterior 
turn in the duet. The eilia with which this part of the tube is provided are probably operative in driving the sex products toward the exterior. There are no evidences that they ever form a groove such as has been described in a few other speries, and it must lather be supposed that both sex products travel much the same path. It the anterior sharp turn of the eoelomoduet the ciliated ridge passes, so lar as mity be judged from seetions, into a ciliated patch that occupies the anterior wall of the canal, and extends a short distance down the posteriorly directed section, corresponding to the shell gland in other solenogastres. This patch, roughly cireular in outline, is composed of low eolumnar cells provided with very long, powerful eilia. Posteriorly the cells of this region blend with others of the same general appearance, but without cilia, and filled with an abundant secretion in several eases in the act of being diwharged. This glandular area is limited to a narrow girlle encircling the duct, and is sharply defined from the sueceeding portions of the canal, whose walls are developed into numerous folds obsenre at first but in the neighborhood of the cloaca of considerable height. The eells in all of this corrugated section, the shell gland of other Neomenima, vary in leight according to the size of the fold of which they form a part, but all agree in being relatively slender with central dense nuclei external to which the eytoplasm is filled with some glandular moduet of yollow tint. In the teminal seetion of the eloaeal passage this substance is present in considerable quantities and at various points has made its escape in an unchanged condition into the neighboring duet.

Proneomenia hawaiiensis, sp. nur.

This species is represented by three individuals, one perfeet and two mutilated. The first was dredged in the neighborhood of Kapuai Point off the western extremity of Kauai Island (Sta. 4001) at a depth of $230-277$ fath. where the bot tom consisted of coarse sand and the temperature was $44.3^{\circ} \mathrm{F}$. The imperfect specinnens were taken in the vieinity of Mokuhooniki Islet (Mokuo Niki), a small istind close to the eastern border of Molokai Island (Sta. 3864) at a depth of 163-19S fath. where the temperature was $57.5^{\circ} \mathrm{F}$. and the battom consisted of shells and finc volcanic sand. All the speeimens came in unattached and without any food in the digestive tract so that nothing is known of their mode of life.

The perforet individual measured $36 \mathrm{~mm}$. in length and 2 in average diameter, and this proportion of $1: 18$ appeared to be the same in the imperfect specimens. The body (Plate-3, fig. 10) is elongated, tapering gently from the forward to the hinder end, and is slightly elliptical in cross section. A rusty red incrusta- 
tion covered the entire animal save the anterior tip and the lips, where the color was light lemon-yellow.

As in other members of the genus the atrial opening is subterminal and presents the appearanee of an elongated slit eneireled by rounded lips. Immediately behind it the ventral furrow takes its rise and extends to the posterior and of the body where it becomes continuous with the subterminal doateal opening. Fections show a well-defined dorsal sense organ with small surrounding spines (Plate 32, fig. 10) but owing to the debris enclusting the body this was not extermally visible.

With the exception of the rentral furrow the body is covered by a relatively thick cuticle that must be an eflicient means of protection and at the same time render the aninal relatively sluggish. As usual inmumerable "alcareous spicules are inbedded in the cuticle, forming five or six irregular layers. These spines are of two distinct types; one, the larger and more abundant form with rounded extremities (l'ate 37 , fig. 5a) is placed more or less parallel with the hypodermis while the second (b) extends at right angles to it and projects slightly above the external body surface. Spines of somewhat this same general form are located along the ventral furrow and about the atrial and cloacal openings; but in their mode of development and owing to numerous intermediate stages it may be seen that they belong to the first class. A more detailed deseription of the position and development of the spines of this species is given on page 28 .

The cuticle is penetrated also by many papillae whose arrangement and general appearance are shown (l'ate 33, fig. 3). As Hansen has noted they appear like so many baloons situated inmediately below the external surface of the cuticle and connected with the hypodermis by a slender fibre. This distal expanded part appears to consist of sereral cells each with basally placed nucleus and an outer vacuolated seetion which usually fuses with the corresponding part of the other cells. These elements pass without any sharp line of demarcation into the stalk that contains from four to six elongated nuclei and in turn unites without definite eell boundaries with a small number of cells of the hypodermis. In many cases delicate fibres may be traced from these hypodermal cells into the decper tiscues of the body, and at the anterior end of the animal they may occasionally be followed into close proximity to the ganglionic layer surrounding the atrial wall; nevertheless while appearances seem to favor the belief that these are nerve fibres and the papillate are sense organs the evidence is not complete.

The pedal gland is coextensive with the foot and consists of two long slender 
bands of cells situated a short distance within the hody on earch side of the ventral furrow into which their secretion is poured. In the body proper the position, size, and number of the component cells in eross seetion is shown (l'late 14, fig. 3). This condition of affail's exists to the front end of the gonad where the gland cells become more abundant and of larger size, oceupying approximately one fourth of the visceral cavity at the level of the posterior end of the radula. Theil outlets still eontinue in the ventral furrow and in addition occur thronghout the region of the anterior division of the foot, which contains extensive blood lacunate and may probably be protruded at times beyond the ventral furrow.

The anterion pedal gland abuts against the front end of the pedal glamel proper and, occupying more than half of the space between the buecal mass and the body wall, extends as far forward as the brain. The main body of each of its cells eonsists of spongy cytoplasm contaning an abundant secretion that stains faintly in Delafield's haematoxylin. The inclueled meleus is relatively very matl, gramular and very irregular in form. Several cells are usually grouped logether and surrounded ly a few comnective-tistue fibres. Each cell is attached by a duct with the vental furrow chiefly in front of the foot. All of the ductules of both pedal glands open between the cells of the vental furrow.

The atrial opening leads inte a ravity of relatively generous proportions (Plate 5, fig. 2) with walls abundantly supplied with semse organs of several dilferent types. The most external of these, which I latwo termed the outer atrial ridge (Plate 14, fig. 1), presents the appearance of a low prominenes situated just within the lips and encircling the atrium except in the mid line behind. lts cells are comparatively slender and in addition to the darkly staining and usually basally situated nuelei, they contain numbers of greenish yellow pigment granules. Lying in contact with the imner ends of these cells is an accumulation of ganglion cells forming an elongated mass coextensive with the ridge itself. From it nerve fibres may readily be traced to the sensory cells adjoining, and in an opposite direction large nerves oceasionally pass inward, and soon become confused with the ganglionic elements attached to the bases of the cirri above. That this is a highly semsory strueture there is no reasonable doubt, but to define its function more accurately is at present impossible.

Of almust identically the same length as the sensory ridge just described and directly in contact with its immer border is another inwardly projecting fold of much greater height and widely different character. It likewise encireles the atrium save on the posterior side where its free extremities unite with another ridge of comesponding height and appearance that farther within the body also 
eneireles the atrial avity. The opithelial celk bounding these ridges (Mundleisten) are colummar, richly riliated and besides the eentrally placed spherieat nucleus contain a small guantity of greenish yellow pigment. Within the ridges are a fow ronuertive and musele elements and an vecasional nerve filne, all loosely arranged and permitting the entrance of multitudes of blood corpuscles that probably eame the distension of these organs.

The area bounded by these fwo sensory prominenees is the airose region characterized by the presence of numbers of hollow finger-haped projections each attached by its base and extending into the atrial cavity. The colls romposing these organs differ to some extent in different specimens but agree in being low, non-ciliated, and charged with a considerable cuantity of the usual greenish yellow pigment and a varying anount of some hyaline seeretion that often covers their external surface. More slender elements, sant in numbers, oecur among these ordinary cells; they may be sensory but some at least appear" to be cells from which the secretjon las reently becn dircharged. The cavity within each eirrus is usually very slender and is travered hy a muscle and nerve fibre. In very exceptionil cases there are one or two blood corpuseles; lut neither in this nor in other speries of solenogastres have I foumd any indication that these pay an important part in the process of respiration. Beneath the cirri is a felt-work of musele, enmective and nerve fibres together with blood corpuscles and lencocytex beyond which is a mass of ganglion cells connected with the eentral nervous sistem and on the other hand with sone organs of the atrium and probably of the hypolernis.

A very slort distance within the imer ridge the dignestive tract narrows rather abruptly, the character of the epithelial lining changes radically, and sinee it marks the point of cutranee of the dorsal salivary gland it may be cunsidered the line separating the mouth and pharynx. According to such an interpretation the pharyngeal wall, lined with a rolatively heary cuticle, is thrown into a series of ridges that course more ar less longitudinally throughout its entire extent. In the majority of cases the cells are high, with central oval numlens and a slight secretion that hat escaped at various points through some of the exceedingly minute pores passing through the lining cuticle.

The so-ealled dorsal, or accesiory, salivary gland is attached to the dorsal wall of the pharynx immediately behind the brain (Plate 5, fig. 2). The cells composing it are one layer thick, and as the duct itself is short and unbranched the gland is necessarily compact and globular in form. The epithelial lining of the pharynx is continued inward to form the lining of the duct between whose 
eells the secretion is diseharged. The cells of the gland are omparatively large, with small nuclei and an alundince of a lightly staining secretion, and are grouped into several clusters separated from each other by a small amount of comnective tissue.

The paired rentral salivary glands are lomg tubular unbanehed structures opening into the pharynx on each side of the front end of the radula. Their position and general appearanee are represented (Plate 14, figs. 7, 9). Each constituent cell is high and colummar in form, composed of varuolated cytoplasm and possessed with nuclei ranging from spherical to slender spindle-statued forms correlated with different stages of glandular activity. The seretion within the main duct is fincly granular and has only a slight affinity for logwood dyes.

In this species the radula is relatively well developed and is focated as in other members of the gemus. The teeth are formed ly odontoblastis of the usual high columnar type chatseteristic of the ("hitons and prosobanchs and are of the form represented (Plate 34, fig. 13). Ill the teeth are of escentially the same form and number not less than from thity y-eight to forty-five in each transverse row: There is no indication of a median tooth so far as the sections show but each tooth adjacent to the mid line is somewhat smaller than its fellows (l'late 34 , fig. 13). In some species of folenogastres the teeth are reported to be merely thickenings of a continuons enticular plate, but in this speeies they are clearly distinct, a well-defined suture not only separating each tooth from the others but from the basal plate as well.

Immediately in front of the radula and somewhat covered by its formard border are two areas of high colummale cells (Plate 34, fig. 2) that are more or less sunken in a well-defined sheath. In another place (Heath '04) it has been shown that these organs probably eorrespond to the subradular organ in the Chitons and some of the prosohranchs. Their innervation is discussed in the section on the nervous system.

The ustal relation of pharyx and stomach-intestine are shown (Plate 5, lig. 2). In another specimen the anterion dorsal coecum is considerably more developed and there is also a small ventral one that cxtends forwat between the salivary glands. A whort distance behind the pharynx the cells of the digestive tract shade gradually into the relatively high pyiform hepatie cells of the stomach-intestine. There are strong evidences that the distal part of these cells loaded with secretory products separates from the rentaining mueleated portions and dissolves in the allimentary that and that the process is repeated indefinitely, the basal nucleated parts developing anew the glandular distal portions. 
Upon rearhing the front end of the eloacal passage (slime gland) (Plate 14, figs. 5, 6) the alimentary canal bocomes crescent-sbaped in cross section, the coneave surface being in contact with the gonad. Before reaching the cloaea it becomes elliptical and the epithelial lining is developed into longitudinal folds that persict to the anal opening.

The heart is irregularly cylindrieal in form, lacks any clear subdivisions and is attached to the dorsal wall of the perieardium. From its anterior end the dorsal aorta takes its origin and coursing forward between the gonad and the body wall funally makes its way into the roughly defined head eavity. At irregular intervals it gives rise to small ventral branches that pas between the halves of the reproductive gland and enter a sinus lying along the under side of the organ. From this vessel bateral branches extend around the sides of the gonad and open into the visecral cavity dorsally. This relation of aorta and gonad continues as long as any trace of the latter exists, and anterior to this point the aorta gradually enlarges and finally in the neighborhood of the brain pasces into the "head cavity." This last named spaee is not bounded posteriorly by a septum, but is well defined by the from end of the pedal gland through and around which the blood passes backward by small chamnels into the viseeral cavity proper. This large sinus smomding the digestive tract is subdivided into two roughly defined spaces, a relatively large sinus lying beneath the intestine and a very much smaller one located between it and the foot. At irrogular intervals these two communicate and small lateral canals also commect the pedal sinus with the main section of the viseral cavity. The latter also conmunicates with the ventral intestinal sinus by fairly well-defined lateral canals that oecupy positions between the gut pouches. In the neighborbood of the cloacal passage these minor sinuses unite with the larger and the blood, that has travelled backward in all of them, makes its way dorsally to open into the hinder end of the heart.

In a foregoing acrount (Heath '04) the nervoms sytem of this species has been described and in this comection it is only neessary to mention the more prominent features. As is represented (Plate 5, fig. 2), the brain is situated in a depression immediately in front of the dorsal salivary glands. Anteriorly it derelops six nerves whose brauches supply in large moasure the sense organs of the bufcal wall and probably the hypodermis and the musculature of adjoining regions. Posteriorly it gives rise to three pairs of nerves, the lateral, pedal, and labio-buceal connectives. The literal cord almost immediately takes up its permanent position at the sides of the body; the pedal passes downward and 
backward to unite with the pedal ganglia that occupy the usual ventral position; white the labio-buecal connectives pass hatekwart along the sides of the pharyx and unite with the labio-bucal ganglia that are placed at the sides of the radula. About mid way between the brain and ganglia the labio-buceal connectives are united by a commisture (dorsal buecal) that passes across the dorsal side of the pharyngeal wall, while a second (ventral buceal) passing over the radula unites the buccal ganglia. Fach of these last named nerve mases, connected by the well-known commissure dorsal to the rachular sar, gives lise to a prominent nerve that passes inward and unites with a ganglion situated near the base each of the subradular organs mentioned in connection with the radula. Each subradular ganghion is in turn comnected with a commisure imbedded in the tissue beneath the pharynx. The relations of these ganglia and the attendant sense organs is essentially the same as in the Polyplacophora. They are mued more concentrated in the latter gromp but the various elements may be readily homologized.

Through the body proper the pedal and lateral cords are united by connectives corresponting roughly to the number of gut pouches. About the same number of eommissures also unite the pedal cords. These comectives and commisures disappear about the middle of the slime gland and a short distance beyond this point the pedil colde disappear apparently without forming a posterior connective (Plate 13, fig. 4). The lateral cords on the other hand pass into the posterior ganglia that give rise to many nerves supplying the surounding tissues and are united by a strong commissure dorsal to the intestine. In the mid line this eommissure develops a nerve that supplies the dorsal sense organ.

The dorsal sense organ is loeated on the mid dorsal line a short distance from the hind end of the animal. Seetions slow that the cuticle in this region is almost wholly lacking and that the neighboring spines hend over and protect the otherwise naked sonsory area. In each specimen the spines were much worn and the upper part of the sencory hollow was filled with dobris so that no outward sign of this organ was visible. In one individual, probubly almormal in this regard, there were two dorsal sense organs, one a short distance in front of the other in the mid line. The posterior one corresponds most elosely to the single one of the other individuals and will be first deseribed.

The cuticle over the sensory region is ahmost wholly absent and the hypodermal cells, that ordinarily are small and distinct, become clearly defined, columnar, and depressed below the general level of the hypodermis. To the 
bottom of this hollow are attather a group of ganglion cells that connect in turn with at nerve from the postpallial commisure. Several musele filses are atso united to the base of this organ. Iudging from atplearaness the pressure of the blood beneath causes an erersion of the cells of the sensory pit bringing them to the level of the gencral body surfare while the contraction of the musele fibres produces their withdrawal and, if of sulficiont strength, the overarching of the surrounding spieules.

The anomatous sense organ mentioned previonsly as occurring slightly in front of the dorsal organ proper consists of 1 wo sensoly pits in atl cxisential respects like the one just described. They are separated lyy a ridge (Plate 32 , fig. 10) on which the spines are relatively smitl and the hypodemal epithelium only slightly different from that found over the body elsewhere. Nerves from the post lateral (pallial) commissure pass to the depressed area that thus appears to be the sense organ proper".

As in other solenogastres the hermaphrodite gland is in the form of two greatly elongated sacs closely appressed along the mid line and extending nearly as far forward at the brain. As usual the ova are developed along the inner wall while the spermatozoa are produced more externally. In the region of the heart cach half of the gonad becomes narrowed to at small duet that communi"at as with the front end of the perieardium, which in one of the sperimens wats of large size and tilled with sex products.

from the postero-lateral borders of the pericardium the eosomoducts arise (Plate 13, fig. 4) as relatirely slender tuhes, and coursing forwird and downward make their way by a fairly direct course to at point near the front end of the shell ghand into which they open. Each eamal is in the form of a greatly elongated spindle lined throughout the first part of its comrse with low that cells, having indistinet boundaries like those of the pericatdial cavity. In the middle enlanged section they attain a greater height heconing nearly eubieal, a shape they roun throughont the remainder of this scetion of the genital canal.

The shell gland or slime gland is a comparatively voluminous organ roughly C-shaped in form (Plate 11, fig. 5). Interiorly each limb communicates with the spiral seminal receptacle and the section of the gonoduet just deseribed whilo posteriorly both unite and enter the cloacia by a comparatively narrow opening. In striking eontrast to the low epithelium of the dorsal limb of tho genital canal the lining cells of this section possess clourly defined walls, are high and slender, and are glandular in character. Those in the neighborhood of the seminal receptacle differ considerably in the nature of their secretion from those of the 
succeeding portions. With the exception of a small mass of protoplasm containing the spherical granular nucleus the cytoplasm is charged with a product apparently nuciform, staning intensely with logwood dyes. In many cases the material has been discharged leaving a relatively spongy protoplasmic matrix. When relieved of their load the cells show no sign of degeneration but continue to elaborate the secretion which forms as minute granules uniformly distributed throughout the protoplasm. Is these increase in amount they mite, finally becoming one confluent mass that admest completely fills the ectls. In the only other speeimen which was sectioned this portion of the gomoduct is composed of cellular eloments of the same appearance, but the seeretion is hyaline and unaffected by Delafield's haematoxylin, a condition of affairs due in all probability to a different phase of ghandular activity.

In both specimens these cells of the anteriou third of the shell gland blend rather gradually with those of the suceceding section of the duct. As Hubrecht notes in Proncomenia sluiteri the cells are very slender elongated elements with basal nucleus and a secretion, developing at first in the form of mimute granules which subsecpuently fuse and form particles of larger size until one great droplet occupies almost the entire cell often crushing the nucless into an almost indistinguithable mass. It is worthy of note that all the eells in a fairly well-rlefined area are usually in the sume stage of activity, perhaps discharging their burden while those of neighboring regions mat be entering into the first stages of the process. In many cases where the secretion has recently been discharged it acts as a highly viscons fluid that only gradually underoges liquifaction and fills the humen of the cloacal passage.

Proneomenia insularis, sp. nov.

This speeies is represented hy a small portion of the anterion end of one individual including the radulat and the comparatively long ventral salivaly glands.

The specimen was found in the bottom of a jar containing some aleyomarian corals that were dredged near Bird Island (Nta. 4157) at a depth of $762-1,000$ fath. where the bottom consisted of white mul and foraminiferous sand with a temperature of $38^{\circ}$. In external appearance and especially in the relations and structure of the eirri, atrial ridges, the radula, salivary glands, and other of the more important organs this species shows a very close resemblance to the species of Proneomenia just described; aceorlingly I have very little hesitancy in placing it in this gemus. The present fragnent, cylindrical in cross section 
save for a slight flattening of the rentral surface, measured about $1.5 \mathrm{~mm}$. in diameter and teminated anteriorly by a rounded extremity (late 8, fig. 4). There is no erest. Its enveloping cuticle, of the usual yellow color, is comparatively thiek and contains large numbers of tapering spicules with rounded end: (Plate 37, fig. 16). Another type of spine occurs in the deeper layers of the cuticle in the form of relatively short basally truncated bodies which are in rontact with a stalked cell of the hypodermis. In the case of the larger spicules of this character the sharp distal point may protrude freely abose the cutiele.

The anterior pedal gland is relatively voluminous, extending forward as far as the cirrose area, posteriorly to the front end of the oesophagus and filling nearly all of the viseeral space hetween these two boundaries. As has been noted in other species of the genus this gland opens separately into a comparatively large space situated behind the mouth opening and continuous with the front end of the pedal furrow. Posteriorly this organ passes without a sharp line of demareation into the pedal gland proper that holds the same relation to the amimal as in the preceding species, but in bulk and in size of its cells it is probably twice as large. Behind the opening into which the anterior pedal gland pours its recretion the foot commenees as a low median ridge that gradually assumes its full size though this is considerably short of that of the foregoing species.

The opening of the atrium holds the same position and is of the same relative size as in P. hawainensis (Plate 8, fig. 4). The ridges and the cirmos area are likewise very smilar in the two forms. The ciliated ridges are not so high in this species owing possibly to the anount of contained blood and the cirri, somewhat more slender than in the foregoing speeies, are united by their bases into groups of two or three.

The junction of the atrial earity and the pharyx is characterized by a ridge sinitar to that of the preceding speeies, but is not farther marked by the presence of a dorsal salivary gland. A rery few relatively large cells ane situated among the nerve fibres passing out from the brain, but white they are in the eorrect position for the unpaired gland no ducts have been discovered.

The paired salivary glands present the same general appearance as in I'. hawaiensis. In the present specimen each organ extends from its opening at the sides of the formard end of the radula backward twiee the distance from the front end of the animal to the opening of the salivary duet. Beyond this point the remaining portions of the body are missing. The eells are of the wsual high columnar type and are more vacuolated than in any speeimens of the preceding species. 
Ifter extending backward for about half its length the pharynx bendi abruptly upwards and nuites with the stomach-intestine. In the angle thus formed is placed the radula that is eonsiderably shorter than in the foregoing species. The teeth also are much smaller though of somewhat similar slape and judging entirely from longitudinal sections there are probalbly not less than twenty-eight transverse rows with at least twenty-four teeth in each row and possibly more. On the other hand the radular supports, in the form of several transverse rods of compact eonnective tiswe, are more highly developed. 'The relation of the pharynx and the stomach-intestine are sufficiently shown (Plate 8 , fig. 4). The anterior eoecum, the gut ponehes, and the digestive eells are also essentially like those of $P$. hamainensis and require no eomment.

In comnection with the eirculatory system there are no unique characters. Every blood space was crowded with corpuseles, spherical in form, with dense melei and eytoplasm, colorless after treatment with Delaficld's hacmatoxylin, and rontaining several refringent granules.

In this speeies the brain is of medium size, it: greatest diameter equaling one eighth the average dianeter of the body, and is situated some distance belind the mion of the pharyx and mouth. As unal three pairs of nerves pass from its forward and lateral regions to the front part of the boly, beenning lost to view in the region of the cirri or more katerally anong the body museles. The connectives passing batekwad are enmpletely ensheathed in the anterior pedal gland whose granular substance renders it very difficull to follow them to their destination. It has been possible to trace the relatively largo pedal fibres to the peral ganglia, and the lateral connectives to their posit ion along the sides of the body, Inut the labio-huceal comertives are exceedingly difficult to differentiate. Inowever with the aid of high nagnifieation their course has been traced beyond question to the gangtia situated on each side of the pharyx about the level of the radular supports. Each is chararterized by a much elongated spindle shape, the conneetive uniting with its anterior end and the ventral eommissure attaehing posteriorly. This latter nerve arehes over the dorsal side of the radula and otherwise presents the usual appearance. A dorsal bueeal commisure, subradular system, and labial commiswure were not found.

Immediately in front of the radula is a ridge of columnar eells that may correspond to the subradular organ. In several septions it is also possible to distinguish fibres that have the peeuliar refraction of other undoubled nerves; yet in spite of persistent effort it has not been possible to deternine their relations.

Three pedal commissures have been proven to exist and eight palliopedal comnectives, all with the usual relations. 
The paired gonad extends forward to at point slightly behind the lovel of the hinder end of the radula supports. Anteriorly its cells are entirely malle, minute oxa appearing only in the most posterior part of the fragment.

Driomenia pacifica, sils. nor.

Three individuals of this speceies were taken off the southern end of Japan, two from Ose Zaki (Nia. 3716) at a depth of $65-125$ fms. and one from Kagorshima (iulf (sta. 4935) at a depth of 103 fathoms. All were imbedded in a mass of hydroids belonging to the genus sertularella. The body is of uniform diameter, measuring $1 \mathrm{~mm}$, by $9 \mathrm{~mm}$. in length. The color in alcohol was a yellowish white.

No dorso-terminal sense organ has been discosered.

The cuticle is thick and contains an inmumerable number of hollow spicules of varying sizes but with the general form represented in Plate 39, fig. 5. The usual hypodermat cells are not especially favorable for study, but on the other hand those of the papillae (Plate 38 , fig. 10) are exceptionally clear. In the distal portion of each papilla the colls are spindle shaped, usually compact and fincly granular, and appear in many rases at least to be continuous with a slender fibre which traverses the stalk and may he followed readily into the tissue bencath the hypodermal layer. Beyond this point their course camot he determined with certainty and aceordingly there is no clatr evidence as to whether they are miscele or nerve.

The anterior pedal gland, necupying the eustomary position, is eomposed of the usual pyriform cells of average size. Posteriorly it passes without any change, except a decrease in the number of cells, into the posterior pedal gland which aceompanies the foot thromghont its entire extent. The ontlot of the anterior perlal gland (Plate 38 , fig. 1) is a plain walled, globular cavity hearily ciliated. Posteriorly two lateral and one median fold arise on its walls and soon unite to form the foot which continues to the cloacal opening though the two lateral folds become of mall size.

The atrial chamber, distinetly separated from the emainder of the digestive taact hy a spiculoce ridge, is a "avity with walls fashioned into the wsual senwory organs. The inner and outer ridges ane moderatoly low, lorseshoe-shaped ciliated folds nearly eneireling the dumber and bounding the cirrose area. Each cime is very stender, without a distinct cavity and is usually united at its base with one we two others.

The true mouth opening is borne on the summit of a low yet broad proboscis which is separated by a rery narrow spiculose ridge from the outlet of 
the anterior porlal gland. From external view this proboscis is not visible, the ventral furrow anpearing to extend to the atrial chamber. The mouth leads into a slender tube, with irregular longitudinal fokls, and becoming grardually larger as it courses dorsally it opens into the stomadn-intestine. Nhout midway it connects with two shert duets from the salivary glands wedged between the stomach-intestine and the anterior pedal gland in the general position represented (Plate 38, fig. 1). Wach salivaly ghand cell is pyriform, slightly racuolated with distinct eompact nucless and unites with the main outlet by means of a very stender ductule.

The anterior roesum and the adjoining sertion of the gut, is a plain walled

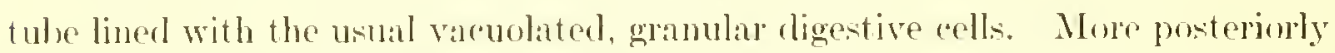
laterat pouches of irregular form apporar (l'late 38 , fig. 1) and may be found at fairly regular intervals as far as the anterior end of the pericardium. Here the canal rapidly narows, becomes cireular in wutline (Plate 38 , figs. 7,9$)$ the epithelial lining is reduced in height and by a slender pore it opens into the cloaeal (chanber whose form and relations are represented (Plate 38, lig. 2). It may be added in this connection that the walls of the doaca are devoid of folds, glandular appendages, or modificat ions of any detinite chararler.

The poricarlial eavity is of noderate size but in one respect differs from that of any other solenogastre. Immediately behind the opening into the gonad the pericandial wall forms two latero-rentral ontpouchings of considerable length (Plate 38, figs. 2, 7). The component cells are low columnar in form, without dofinite signs of glandular antivity and contain relatively large dense nuclei. It is impossible to determine their function though they may be seminal vesicles sines colls of the same general appearance compose the lateral pericardial wall and connect these diverticulat with the imner openings of the coclomoduets.

The heart is of arerage size and comsist of two distinct divisions. The anterior one, without any sharp boundary line is entimuse with the acrta which, throughout its entire length, is a tube of more than wsually great size. Its connections with the gonad and the anterion end of the londy are normal as are those of the risceral sinus. Iarge blowe spaces aceur about the cloacal catvity and as the walls of the latter are thin the exchange of gases may readily take place at this point. The boud compeles vary comsiderably in shape, in some eases being similar to the elongated type found in stophomenia and at other times appestring ahnost globulitr. This may be a post mortem effect but the cells are very well preserved. 
The mervous system is dillicult to trane and areordingly has been exanined in its broader features only wheh show it to be of the wasul trpe.

The single specinen exanined is sexually mature and the repuroductive gland extends as far forward as the level of the salivary glands. While the exge are attatied as usual to the modian wall of the wonad the sperms deverop in lateral pouches. In the presteriore end of the body these crypts are of large size. extending in some "ases far down the sides of the intestine, and they are eonnected with the gonad by small pores (l'late 38, fig. 2).

The coelomoducts arise as relatively small tubes from the posteriog bordere of the perieadium and extend forward to the region of the seminal receptade where as usual they unite with the shell ghand. The lining epithelium is low, the cells cubiral and ciliated and without indioations of being glandular. Lated seminal receptacle is a companatively largo (dub-shaped sac provided with seredal small outpourhings especially on its distal extremity. In these small ponderes multitudes of spermatozna are attarlied to the lining epithelium which is amposed of slender colmminar alls.

The shell gand is in the form of a thick set $\mathbf{Y}$ and an may be seen, Plate 38 , it contains a ravity of molerate size. The greater number of gland reells are of one type, high eolummar elements contaning, large numbers of spherieal granules. In the neighborhool of the opening into the seminal receptacle these are associated with a small mumber of cells containing, after treatment with Delafiedd's haematoxylin, a homogeneous violet colored substance. In rose proximity to the opening into the rloacal chamber the dorsal wall of the gland contains a considerable mumber of ecels, which secrete a coal black substance when treated with the above mentioned stain. All of these glandular elements are in contant with slender supporting colls containing mesially placed spindleshaped muclei.

\section{Dorymenia acuta, sp. nov.}

Eleven specimens of this speries were dredged in the vieinity of the sinta Barlutra Is]ands, off southern California, at depthe ranging from 302-ti3s fathons. The three largest specimens measure $35 \mathrm{~mm}$. in length by 1.25 average diameter, with one exception having a thickness of $2.25 \mathrm{~mm}$. The two smallest individuals are $14 \mathrm{~mm}$. in length by $1 \mathrm{~mm}$. average diameter, and with one axoption, a slightly spindle-shapod individual, all of the sperimens are slender and of about uniform diameter throughout (Plate 3, fig. 11). Their eolor values from a grayish white, where the brick-red color of the liver shines through the cuticle, to light lemon-yellow. The heat is rather sharply pointed, and but slightly 
difforntiated from the body moper, wheh posterionly temmates in a very pointer axtronity as in Promeomenia weberi Niersts. The atrial opening is relatively small, sulsteminal and surromeded by tumid lips which separate it from the ventrul furrew. Is noted in a suceecling paragraph, the anterior podal ghand is highly devedoped, but its outlet is not especially modified extemally. Pesteriorly the podal gronve is contimons with the eloacal cavity. The reloacal opening is relatively large, ventrul and is overarched by the posterior pointed (nd of the hody, whose lateral margins are involuted, but may perhaps be flared moratonatly to expose the genital spieula, the appearance of the hinder end of the aninal resembling at such a time Ichthyomenia ichthyodes Pruvot.

A well-developed dorsal sense organ (Plate 15, fig. 11), visible in sections only, is present a short distance from the posterior end of the body, and is supplied with speeial nerves and blood simues as in P. hawailonsis.

The cuticle investing the body is relatively thick (Plate 33, fig. 4), and is developed hy a lypotermal layer in which the component cells are of small size. Those ust instrumental in the formation of the spieules or papillae are more or less cubieal in form and eonsist of racuolated cytoplasm in which the nucleus, matily spherical, holds a central position. At varions points the muclei are dence and elongated and may posibly belong to sensory cells.

The apicules are hollow needle-lilie structures (Plate 37, fig. 10), those of the alternate layers arosing the others almost at right angles. In their formation 1w prints of especial interest appear. Is usual several cells take part in the process as in P. hauariensis.

'The papillac are of average number and present the appearance represented (Plate 33, fig. 4). Three or fomr spindle-shaped nuclei oceur in the slender fibrous stalk whilo from five to seven are present in the swollen distal portion. In this last named situation the nuder are frerpuently of 1 wo sizes, small dense bodies, and one or two of twice their size with a more vesionlar appearance. Judging from many rections both the number and chanacter of these elements ares due to different stages in the development of the paublate. In ardvanced states these latter organs may open to the exterion and become so filled with debris that the eellular elements save those of the stalk, breome obliterated. This, howerere, in undoubtedly an abnomal eondition and narks the elose of an anction functional existrnce on the part of the papillat.

The anterior pedal grland, as in various other sperios of Neomeniina, is a voluminus organ extending anterionly an far as the brain, posteriorly as far as the forward border of the radula and filling practically all of the space between 
the gut and the body wall. The cells, where not compressed, are pear shaped with a diameter ranging from .0185-035) mm. In the early stages of their existence the eytoplasm is vacuolated and not affected with haematoxylin but with the assmmption of glandular activity the secretion, in the form of fure darkly staining granules, appears in the peripheral portions of the cell gradually filling the more central portions with the execption of the small, and at thic stage, much shrmben nucleus. Delicate ducts, as usual, lead from the cell body to their intercellular opening into the anterior end of the peclal furrow.

from external view the opening of the anterior pedal gland is not marked by any noteworthy peculiarity, but from sections it may be seen that the peclal groove soon expands inwardly into two extensive lateral diverticula (Plate 15, fig. 1), whose anterior walls, in some specimens, are thrown into low folds and more posteriorly are supplied with very heary cilia, ranging from one to three times the length of the supporting cell. Along the median dorsal line a large fold exists which more posteriorly is continuous with the foot. Everywhere throughout this fold and over the anterior folds of each crypt the secretion makes its exit in the form of a very funely granular almost homogeneous substance and after treatment with haematoxylin of a slightly pinkish tint.

The posterior pedal gland is also well developed and eonsists of a rod of cells on earh side of the mid ventral line continuons in front with those of the anterior pedal gland with which they are identieal save for their slightly smaller size. Posteriorly they gradually diminish in bulk and number, and in the region of the cloaea finally disippear.

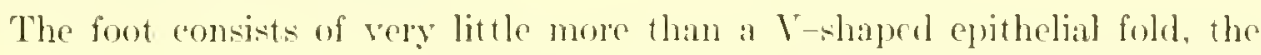
included muscle and comnective tissuc being very seanty, and entirely devoid of blood sinuses or at all events those of sufficiont size to indude blood corpusces in preserved material. Throughunt its entire extent it is acompanied by two small epithelial ridges which are to be considered special modifications of the hypodermis. The inter-cellular openings of the peelal glamel oecur in the angle formed by these ridges and the foot.

The atrial opening, holding the uswal subteminal position, leads into a ravity posessing essentially the same relations as in varions species of Neomeniclae. Like Proneomenia hawriensis, for (xample, there are two conspieuous ridges surrounding the cirrose area, and external to the outer buncal ridge a low elevation encireles the cavity save in the mid line posteriorly. From this clevation numerous delieate fibrils may be traced to a rod-like acemumbation of ganglion colls coextensive with the ridge itsolf. On the other hand these 
nerve cells annow by relatively large norve bundles with the ganglia located neatr the bases of the cirri.

()f the ciliatch ridges (Mlmallesten) the more external are in the form of two olarations which apponath areh other very elosely in front and behind, at which points they hecome low and inconspicuous though in their mid section they are compantively high. The imner ridge has the form of a horseshoe, the fres axtremities connerting posteriorly with the ends of the outer ridge.

This inner prominenee is relatively short yet high, and like the outer contains a lowe nuchwork of muscle and eomnectire-tissue fibres among which are mumbrous blood corpuseles. The cells composing them present much the same appearancas as those of the outer low elevation deseribed in the preceding parigraph. Practically all are slender and contain sull anounts of pigment and elongated nuclei. Nerve fibres may be followed into the ridges which thus somn to be sensory. In $P$. hamaiensis these cells are richly ciliated, but in this speeios all traces of eilia aro absent and, it may be added, the matcrial is exeetlently preservert.

Within the eirrose area and lying behind the innermost ridge the atrial wall in the nuid line is developed into a fold, of large size, which is elosely packed with multitules of blool conpuseles. If the buecal rolges serve as respiratory organs, as some authors would lave us believe, this structure is certainly more efficiont sine it is not only voluminous but its epitleelial covering is not more than one thiret as thick as that of the general atrial eavity.

The cirri are prominent structures in this species, being not only numerous but of comsiderable length and calibre. Each is composed of cubical or low colummar eolls filled to a eomiderable extent with the usual yellowish pigment which more or less conceals the small centrally placed spherieal nucleus. At valums points those orguns may arise singly from the buceal wall, but usually the bases of from four to six are fused, and into this stalk musele and occasionally nerve filores maly be traced. The cavity of the single rirrus is usually so small that the relation of these fibres remains unkmown and, it may be noted, effectually blocks the entrance of blood cells, so that these orgatus are rather to be considered retratile sensory ongans with little respiratory function.

A short distance behind the cirrose area the pharynx originates as a tube with somewhat smallor diameter than the atrial cavity. However, immediately Lohind the region of the brain the canal from external view expands considerably, hut sections of this rewion show that at grat fold develops in the pharyngeal wall which it entirely encirches leclucing the cavity to a crescentic slit (Plate 15, 
figs. 1, 7). Numerous muscles inserted in the tissue of the fold and on the other hand to the body wall doubtless serve to dilate the camal when the animal is in the act of feeding. Immediately behind this fold, and therefore in the region of the radula, the eanal becomes much wider but more posteriorly again narows and by a comparatively small opening communicates with the stomach-intestine. Throughout the entire extent of the pharyx its epithelial lining is throw into numerous longitudinal folds, especially in the neighborhood of the lathlula whene they become wary and in sections present a most complicated apposance. In general the eells of the pharyngeal epithelimm are low colmunar elements devoid of eilia and overlaid with a clearly defined cuticular layer.

Two sets of salivary glands are present, a ventral pair and a group of ecolls imbedcled in the large fold just mentioned. The eclls of the last named gland, which is probably the homologue of the dorsal salivary gland of several other species of solenogastres, are not grouper compartly as in P. hawaionsis, for example, but are seattered thromghont the tiswe of the fold and open by separate pores over its entire extent. All the eells are byriform and in early stages are composed of a fincly racuolated cytoplasm in which the secretion ultimately makes its appearance in the form of distinct granules of eomparatively large size. These rarely aecumulate to a sufficient extent to hide the nucleus but make their way by well-defined ducts to open ly interedlutar channels into the pharymgeal cavity.

The ventral salivary glands open into the pharynx at the sides of the extreme tip of the radula, and in the form of tubular outgrowths extend backward for a distance of $3.5 \mathrm{~mm}$. As may be seen (l'ate 15, fig. 2), the duets are of large size and are bounded by slender cells denecly filled with a secretion having mueh the same appearance as that developed in the dorsal set.

The radula is of the polystichons tyen, and juelging wholly from serotions consists of 4S-51 rows with twenty-two teoth in each row. All the teeth are of essentially the same shape (Plate 34, figs. 7, 11) and size with the execption of those on each side of the mid line which anpear to loe slightly smaller. I very thin yet clearly defined basement membrane is present.

The radula sac rests upon a support consisting of a serios of globulal cello of which two are of relatively large size and are located symmetrically on each side of the mid line. All of these contain nuclei and a fincly granular eytoplasm, which in the larger eclls is usually greatly slomiken. To these supports numerous muscles attach, but from sertions it is most diffienle to deseribe their relations and define their function. 
The matrix cells of the radula are comparatively small and the teeth mumeroms so that an areurate determination of the development of the teeth and basement memblane is difficult. Odontoblasts, holding the ordinary position and with the usual appeartunce are present and numerous enamel cells arise from the lottom of the radular sac. These latter elements may be traced forward a short distance among the newly developed teeth where they disappear. The rells rewmenslyle for the formation of the basement membrane are not unlike the olontoblasts all of which blend with the epithelial cells of the ventral side of the radular sae. In all essential respects therefore the development of the radulu in this species is not mnlike what exists in Limifossor talpoideus.

Immediately behind the opening of the pharynx into the intestine the walls of the latter develop a circular fold (l'late 15, fig. 7) which in life may be less contrated and serve as a valve. Anteriol to it the intestinal coecum extends as far forward as the brain. It is almost wholly devoid of divertieula, though its low epithelial lining is thrown into numerous small folds on its ventral surface. Slightly behind the valve-like fold just mentioned the intestine proper arises, "haracterized by diverticula of almost mathematical regularity lined by the usual high (lub-shaped digestive cells, exeept underneath the gonad where the intestinal epithelinm loses its glandular charaeter and its low columnar cells suppost a coat of cilia. This state of affairs continues to the front end of the coelomoluets where the eanal rapidly decreases in diameter and becomes ciliated throughout. Making its way to the dorsal side of the animal it passes between the perieardim and gonoduet to open into the eloacal ehamber.

The periardial eavity is a comparatively larese space whose general shape and relations may be detemined from Plate 6 , fig. 4. The cells composing its "pithelial lining are indintinct in outline, yet, judging from the nudei, are more numeron than in any other species of solenogastre described in the present paper. The heart also is of large size (Plate 15, figs. 4, 6) in both speeimens which weresectioned, and very elearly consists of an auricle and ventricle. The first named division is much distended and the walls are thin and delieate, consisting externally of an epitholial sheet resembling that lining the perieardium, internally supportal by a few musele fibres. These form a loose meshwork from whieh oreasional filmes pass acrosis the auricular eavity to be inserted elsewhere in the wall. The long, sharply defined median dor'sal sinus, extending from the posterior end of the body, mlirges as it passes forward and enters the auriele on its posterior lomer: As usual the ventricular walls are of greater thickness and the spares formed by the interlacing fibres relatively small and filled with groups 
of corpuscles. Anteriorly it passes into the aorta which, passing between the two widely separated ducts from the gronad, becomes a ressel of large diameter.

The vessels to the gonad, and the exit of these into the viseeral cavity and the communication of the dorsal sinus with the numerous channels in the head region are of the usual type. The sinuses of the head are relatively small yet may readily be followed through the anterior pedal gland and about the bueral wall to a small median ventral simus situated above the outlet of the anterior pedal gland. Above the forward end of the foot this median sinus widens greatly, and during its journey to the posterior end of the body communicates here and there with the viseeral simus and at various points is divided horizontally by a museular septum, thus forming two fairly complete simuses one above the other. In the region of the coclomoducts these ehamnels become sharply defined, though as they approach the cloaca, the ventral one, in frequent communication with the dorsal, gradually diminishes and at the termination of the foot vanishes completely. The remaining ventral sinus has likewise greatly decreased in size in this same region, and communicating frequently with the outlying visceral eavity disappears immediately in front of the cloaca. At the sides of the eloacal cavity and posterior to it the blood probably passes backward in the ventral half of the body, and by means of numerous channels passes into the dorsal half where it is transferred to the heart by several lacumae, the median dorsal one being most clearly defined. The corpuscles are about two thirds the size of those of Proneomenia which otherwise they closely resemble (Plate 35 , fig. 13).

It will be seen (Plate 6, fig. 4 and P'ate 9, fig. 2), that the coclomoducts arise from the postero-lateral borders of the perieardium by relatively large openings. and extending forward as far as the anterior extremity of the heart communicate by a narrow canal with the conical scminal receptacle, and by a larger opening with the last section, of larger calibre, which unites with a corresponding tube of the opposite side and by a single median opening communieates with the cloaeal cavity. Immediately beyond its inner opening the epithelial lining of each duct is thrown into prominent ridges composed of slenter cilinted enls in which there are faint traces of glandular activity, which may posibly become more pronounced during the breeding period. Ilalf way to the seminal receptate the ridges disappear and the cells beeome lower, more cubical, and apparently are possessed of cilia. Furthemore throughout this same section of the callal some of the cells of its outer half become much elongated and formstrands which 
bridge the cavity. In the neighlembod of the seminat receptacte these are numerous but what their ollies may be it is dilficult to conjecture.

The seminal receptale is a thin-walled subconical sac pwovided with very slight intrmal folds and composed of low cubical cells which bear no trace of viliat nor receretory products. During the time it is filled with sperms, however, the cells become more or less liquilied, the nuclei relatively large and pale after tratment with haematoxylin and great numbers of spermatozoa beeome imbedded in their sulstance. It unites by means of a short narrow eanal with the condomoduct at the point where the first and seeond sections meet.

The second rection of the coelomoduet, or shell gland, is a tube of comparatively large size (Plate 15, figs. 4, 6). In the anterior third its walls are thin, almost devoid of folds and the eells composing it vary from cubical elements to others of low cohmmar form, if the animal be immature or out of the breeding seaton. Is thin last mentioned time approaches the cells become greatly thickcned and the meatre secretion becomes abundant, filling the eell as a dark, almost black, substance like that of the mueiparous gland in many molluses. This condition of affatrs continues along the mid ventral line of the duct for a considerable distance posteriorly. The same modifieations oecur in the sueceeding portions of the coclomoduct, but as the time of sexual activity approaches the cells become greatly elongated, are thrown into large transverse folds and are filled with a faintly yellowish secretion which at other times is scarcely visible.

In this species, as in P. weberi, two genital spicula are present and of large size (Plate 6, fig. 4). Each is inserted in a deep sheath, a diverticulum of the wall of the cloacal cavity, which extends forward and slightly upward to a point about level with the base of the seminal receptacle. The cells of the distal extremity, which are probably the spicule-matrix eells, are very slender elements (Plate 15, fig. 10), with dense spindle-shaped nuelei imbedded in an almost homogencous eytoplasm having somewhat the appearanee of the odontoblasts of various molluses. Throughout the remainder of the sheath, especially on its inner half, the eells are considerably smaller and their distal portion appears to be more or less cuticularized (Plate 15, fig. 5).

Two powerful sets of muceles, the retractors and protractors, attach to the sheath (Plate 9, fig. 2). The first named eonsists of a large number of ninor bands inserted in the distal end, and on the other hand to the body wall, after having spread out fan-like, a short distance anterior to the seminal receptacle. The protractors are more numerous and attach at various points within a narrow 
zone immediately behind the retractors. On the other hathl, after pasing backward, the rarious groups of fibres become attached to the body wall or to the eloacal wall in the neighborhood of the opening of the spicule sheath. Numerous other strands occur in this region whose function it is to widen the eloaea, enabling the spicule to be exposed while others lring alout a counter movement. Those active in the first operation consist of many lands paswing radially from the wall of the eloaca to become inserted in the bouly wall, and others which pass from the eloacal wall anteriorly to blend with the somatic museles. The remainder, responsible for the reduction of the cloalcal cavity, comprise many filmes which attach to the walls of the cloalcal carity, and passing backward unite with the body wall on each side of the forward border of the cloacal opening.

A pair of curious vesicles, irregular in form but of comparatively lange -ize, oceur one on each side of the body wedged in between the cloacal wall, spicule sheath, and coelomoduct and, as sections show (Plate 15, fig. 4), they are sepa= rated from each other by a thin vertical wall. On the posterior face of each a short slender tube communicates with the cloaca (Plate 9, fig. 2). In inmature individuals or those not sexually active the walls are comparatively thin, and are composed of cells eubical or low columnar in form without any distinct signs of glandular aetivity; but as the breeding season approaches the walls becone much thickened and each cell develops some substance which gives it a longitudinally striated appearance. This materiat remains unstaned in haematoxylin and as it forms crowds the nucleus to the distal end. There is some evidence, though scanty, that this secretion is poured into the diverticulum and there becomes transformed into a dirkly staining mucus-like substance which everywhere lines the walls. Here and there are blood sinuses filled with corpuseles especially in the region of the opening into the cloaca where the colls are lower, without secretory products and covered with an abundance of cilia.

The fact that these modifications oceur simulaneously with those of the gonoducts strongly suggests that these organs in some way play at pall in the reproductive process. They may function as uteri but obviously such conjectures are of very little value at the present time.

There is some reason to believe that the type of coelonoduct found in Chatoderma is more like that of C'hiton, and accordingly of a more primitive type than in the Neomenima where they are provided with seminal receptacdes, glands often of enormous development and spicula, in some cases, provided also with glandular appendages. It is interesting to note that in an immature 
rendition some of howe more mondified types present a simpler condition than at at later statge. In small specimens of the present species, about $14 \mathrm{~mm}$. in length the virious organs, connected with the reproductive system, hold the rolitions dereribed above but they are far from being functional. The gonad, for example, is clearly paired throughout its entire length and the epithelium shows the merest traces of reproductive activity. The folds of germinal epithelium, that form a most "haracteristic feature of the adult organ, are commeneing to appear on the latero-ventral surfare of the gland, and there are slight evidenees of a proliferation of arls on the inner wall of each gland. The dorsal aorta or sinus is of unusual size and in some places separates the two halves of the gonad completely, especially in front of the heart, where they are distant from each other by an interval ectual to one third the diameter of the body. Thus widely separated they open into the pericardium, which, as in the adult, is of large sizc (Plate 15, fig. 9). The heart likewise is typical. The ducts leading to the exterior are of essentially the same calibre throughout; the seminal receptacle terminates anteriorly in a relatively long flagellum-like process; the spicule sheathe have developed though there are no traces of the organie basis of the spicules themselves as in decaleified specimens of larger size; and the vericles opening into the cloaca are both present though their outlets are relatively large. Above all there are no signs of glandular aetivity. As noted on page 169 if these ducts are in part excretory this phase of activity should appear long before sexual maturity and its absence indicates that these tubes are merely for earrying off sex products.

In this species the sheath surrounding the nerve bundles is of unusual density or at all events stains with uncommon intensity in haematoxylin, so that branches not over $0.002 \mathrm{~mm}$. have been followed. Owing to this fact more than usual care has been taken to determine the distribution of the more important trunks.

The brain, holding the customary position, dorsal to the pharyns, is of medium size and very clearly bilobed. From its anterior half the usual three pairs of nerves arise and at their origin each is connected with two ganglia, one very minute in size. These fibres extend laterally and antriorly and after branching several times connect with ganglionic masses about the bases of the cirri.

A pair of very small nerves spring from the middle section of the brain close to the junction of its lateral and ventral surfaces. Each of these proceeds latcrally and ventrally, and coming in contact with the sides of the pharymx branches and becomes lost among the numerous muscle fibres. 
From the posterior half of the brain the lateral, porlal and lathio-luecal connectives take their rise from independent, distinet roots (1'late 13, fig. I). In side view the first two appear to be relativcly short but in roulity they extend laterally for a considerable distance at the same time bending ventrally to join the corresponding ganglia. All are practically devoid of ganglion cells. At the junction of each lateral conncetive with the ganglion there is a well-defined enlargement which anteriorly gives rise to a strong fibre passing forward elosely applied to the somatic musculature. In the neighborhood of the atrium it branches repeatedly and the resulting fibres connect in some cascs, at least, with the ganglia in the neighborhood of the cirri. At the union of this cord and the lateral ganglion another nerve appears which likewise rests against the body wall, and after passing forwurd and downward becomes lost to sight after branching a few times. This same anterior enlargement develops one or two very small laterally directed nerves which soon become indistinguishable among the somatic musele fibres.

The lateral and pedal cords traverse the body holding the lsual positions. Throughout their entire extent pedal commissures exist and approximately the same number of comectires unite the pedal and lateral ganglia. In the front end of the body, where the connectives are unusually distinct, they are often found to be united by commissures and accordingly lack the regular arrangement sometimes seen in figures of other species. As seen (Plate 13, fig. 1) the anterior connective gives off a branch that passes forward and secmingly unites with the ganglionic rod of cells attached to the base of the outer atrial ridge. This appears also to be the destination of another nerve originating from the front end of each pedal ganglion.

The labio-buccal ganglia are ellipsoidal bodies resting on the dorsal surface of the ventral salivary glands a short distance behind their out let into the pharynx. From the anterior surface of each a strong nerve arises and in the usually contracted state of preserved material is eonsiderably twisted hefore it expands and breaks up into three strong branches. Of these the more dorsal one is the buceal connective attached to the brain. The one inmediately ventral to it extends anteriorly, slightly imbedded in the pharyngeal musculature until it arrives at the great dorsal fold. Here it bends sharply inward and deeply jmbedded in the musele bands crosses the pharrnx to unite with its fellow giving off one or two delicate fibres on the way. A second dorsal commiswure is formed by two relatively small nerves each of which springs from the anterior face of the labio-bueeal ganglion. These, in eloser proximity to the mid line than the 


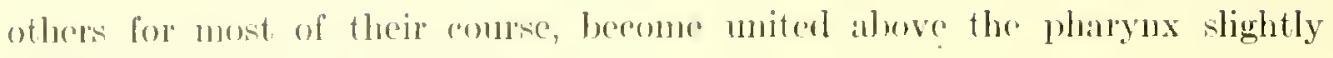
beniud the dorsal pharymgeal fold.

It the junction of the lalio-fuceal commertive and anterior dor:al commissure a thirl norve arises probably to be enswidered the subradular commective. 1 short distance distal to its origin it originates two, sometimes three, small norves which may be traced deep into the pharyngeal museulature in the neighborhood of the ratula. Still farther outward a smatl ganglion is attached to it by a small stalk and between these two bodics the main fibre continues to complete the commissure.

In the posterior part of the body the peclal ganglia decrease rapidly in size, and beeme lost to view without being direetly comected with the lateral cords. In this region the last four or five commissures are more than usually crowded together. The last three comnectives on each side become united before entering the posterior end of the lateral ganglia, which here break up into four strong branches that pass hackward, and after dividing repeatedly become lost in the walls of the cloaca and hody including the posterior elongation. It the point where these nerves arise the lateral cords are joined by means of the eustomary suprarectal commissure.

\section{Strophomenia scandens, sp nov.}

Three specimens of this speeies were taken attached to a colony of Acanthoyorgia armala dredged in the vicinity of Bird Island (Nta. 4156) at a depth of 286-568 fath. where the bottom was white mud and formminferous rock and the temperiture was 45.8 F. The bodies of these animals were wrapped about the stems of the corals as shown (Plate 2, fig. 1), hut none of the polyps in their imnerliate vieinity exhibited a sumken appeatunee as though these molluses lad been indulging their ilppetites as in the case of Drepanomenia. The contents of the alimentary eanal consisted only of a small amount of a finely gramular substance.

The largest specinen moasured $39 \mathrm{~mm}$. in length and $2.1 \mathrm{lmm}$. in diameter; the smallest was $32 \mathrm{~mm}$. Iong with a thicknoss of $1.6 \mathrm{~mm}$. The two ends of the body are similar in appearance, the posterior being slightly more slender and pointed (Plate 2, fig. 1). In crosis section the body is in general nearly circular, but in both of the sperimens at hand the ventral surface is slightly flattened. The atrial opening is an clongated slit surpounded by rounded lips, behind which the ventral furrow commences and pusteriorly is eontinuous with the rloacal opening also subteminal in position. 
The anterior portion of the ventral furrow forms a rebatively deop reprosicion (Plate 12, fig. 1) will corrugated watls, the opening of the anterior perlal gland. The gland itself oceupies most of the visceral cavity in front of the forware (and of the foot (Plate 16, figs, 1, 4). Its cells are of large size relatively, and alre charged with a darkly staining secretion that makes its way by slender duets to the ventral furrow, where each terminates in an intercellular opening. The secretion appears to be viscous, and in one of the specimens carefully dislodged it extended backward for a distance of $22 \mathrm{~mm}$. as a narrow band.

The cuticle enclosing the body is about $0.2 \mathrm{~mm}$. in thickuess and as Plate 16, shows this measurement is very uniform save in the immodiate neighborlookl of the ventral furrow. Imbedded in its substance are, mugly speaking, six to eight layers of spicules, those from the back and sides of the animat being represented (Plate 37, fig. 17). Among these is a much smaller muber of radially directed spines that become more minute and more abundint in the neighborhood of the foot.

The hypodermal layer is remarkably shaply defined, and not including the spicule forming elements and those comnceted with the papillate, consists of cells about fwice as high as broad with greatly vacuolated protoplasm and welldefined nuclei occupying a more or less central position. Ocrasionally more slender cells are eneountered but these may in reality belong to the papillae.

The development of the spicule is essentially the same ats in P. hrumiensis (page 28) both as regards the number and arrangement of the operating cells which also retain their connection with the spine as long as it remains in the cuticle.

As is shown (Plate 32, fig. 3) the papillate are numerous and closely crowded together at the surface. The expanded portion contains not lar from fwenty nuclei and the stalk from 2-5; otherwice there are no espeeial features of inporrtance.

The foot arises in the extreme anterior end of the pedal furmw ats a welldefined median ridge whose bounding eells are apparently covered with smatl eilia; but these are usually obsenred by the huge cilia of the cells situatcel laterally. In the anterior portions of the ventral furrow the secretion from the anterior gland passes through intercellular openings at all points; more posteriorly it passes through the foot and the epithelium in immediate contact with it. The sceretion of the anterior pedal gland when treated with Delaticld's haematoxylin contains one substane which stains ahmost black and another of light blue tint. These appear to be two distinct secretions, for the dark sub- 
stanee escapes high up on the sides of the ventral furrow while the light blue prochet passes ont more ventrally.

Behind the opening of the anterior pedal gland each side of the foot is accompanied by a longitudinal fold, which persists to near the hinder end of the animal when the lateral ridges, decreasing in size, pass into the general hypodermal covering of the body and are covered in large measure by the cuticle in which small spicules may be formed.

The atrial opening leads into a well-defined eavity (Plate 12, fig. 1) whose walls are provided with organs not unlike those in $P$. haucaiensis for example. The outer sensory prominence and the outer and inner ciliated ridges are not so elevated, but the last two are composed of the same type of ciliated cells. At certain points the outer sensory ridge surmounts groups of ganglion cells from which fibres may occasionally be traced into close proximity to nerves that innervate the cirri. Along the median dorsal line another well-defined elevation is present between the two limbs of the inner rilge, but its cells are like those of the ordinary buceal epithelium and are probably not highly sensory.

In eross section the pharynx is roughly semilunar in shape, appearing relatively narrow when viewed from the side, but with a diameter of one fourth that of the body when seen from the dorsal or ventral surface. In front of the opening of the anterior pedal gland its cells are relatively high and slender, finely granular and contain more or less spindle-shaped nuclei placed at different levels. Behind this point the lining retains the same general character, but is developed into numerous and relatively low transverse folds supported by a small amount of connective tissue. Slightly in front of the labio-buccal ganglia the ridges become higher, the underlying connective tissue more abundant and among the cells of the usual type are a few others of more slender appearance with darkly staining elongated nuclei. It is possible that these elements are sensory in function, but owing to the large quantity of musele and connective tissue in the neighborhood no special nerve supply has been distinguished.

Beyond these supposed sensory ridges the digestive tract bends abruptly upon itself and coursing upward and forward unites with the stomach-intestine (Plate 12, fig. 1). There is reason to suppose that this section between the labio-buecal ganglia and the gut represents the oesophagus, but with the exeeption that its epithelial lining consists of more spongy cells not produced into folds there is lit le to distinguish it as such.

The relations of the paired ventral salivary glands (Plate 6, fig. 6) are somewhat peculiar and except in very well-preserved material are diffieult to determine, 
a fact that may be responsible for some of the remarkable relations of these glands as deseribed in some other members of the genus and in Rhopalomenia. In the present species these organs are placed side by side beneath the intestine and extend backward from their outlet for a distance equal to at least four times the diameter of the body. Anteriorly they diverge and enter the pharyngeal wall almost directly above the labio-buceal ganglia. Imbedded in muscle and connective-tissue fibres and some of the outlying pharyngeal glands, each canal now bends sharply upon itself (in two individuals) and becoming much more slender courses downward and somewhat backward to enter the pharymx on its ventral side. From the bend to a point close to their outlet these ducts are not only relatively slender but their lumen is of very small size and save in excellently preserved material, as in one of the specimens, is scarcely to be distinguished from the surrounding tissue. They are also composed of remarkably delicate material for in one specimen in which the organs are in a fairly good state of preservation this section of the gland has macerated and disappeared completely, leaving only the short and firmer outlets into the pharynx and the free main part of the gland.

On the ventral side of the pharynx the glandular portion of each of these organs ceases abruptly and becomes contimous with a eanal of somewhat larger calibre composed of small cubieal cells, that proceeds almost directly inward and opens ventrally into the pharynx close to the mid line. This terminal section of the salivary glands is a conspicuous objeet in sections, but its comection with the adjoining glandular part may be readily overlooked in which ease the terminal section appears to be a short diverticulum of the ventral wall of the pharynx while the gland proper seems to unite with the pharynx near the dorsal side.

In the present species there is in addition to the various divisions of the salivary glands a median diverticulum whose relation to the digestive tract and buceal commissure support the belief that it is a rudimentary radula. The ventral wall of the pharynx forms a shallow pocket and the salivary ducts open into the bottom of this at each side. Exactly in the mid line and immediately above this pouch there is a small posteriorly directed diverticulum of the ventral wall of the pharynx and in two examples the buceal commisure passes dorsal to it (Plate 6, fig. 6), the relations being the same as in the radula of $P$. hawaicens for example. Its epithelial lining eonsists of low cells composed of highly vacuolated eytoplasm in which the nuclei hold a basal position, but there is no sign whatever of teetl. 
(anclatch with the posterior" attachment of the pharynx is the excessive divelopment of the anterior eoecum (Plate 12, fig. 1), that extends forward to the linder limits of the atrial cavity. In one specimen its walls are lined throughont with pyiform digestive "ells, whose clear basal portion holds a small (ompanet nucleus while the vacuolated distal part contains numerous granules chatacteristic of this type of cell. In another individual treated in precisely the same way the granular portion of the colls was absent as was the ase in other parts of the digestive tract. As was noted in the case of $P$. hawairchsis thic appears to be the normal method of ridding the cells of their seeretion. In the hinder portions of the coecum gut pouches appear and becoming more lully developed a short distanee nure posteriorly they continue with much regularity to the region of the heart where they abruptly disappear. Beneath the anterior end of the perixurdium the intestime contimes as a tube of relatively latrge calibse, but at the posterior end it rapidy narrows down to open into the cloaca (see Plate 12).

As in represented (Plate 13, fig. 2, and Plate 16), the pericardium of this pperies is of considerable size and contains in addition to the heart a number of mature ora. Histologiwally the differentiation of auricle and ventricle is not clearly marked and save for a constriction there is nothing to distinguish these two divisions. The blood occupying the interstices between all the organs in the posterior part of the body passes into the auricle by a wide opening and thence pours into the ventricle through an aperture not guarded by clearly defined valves. From the forwarl end of the heart the aorta takes its rise and with the usual position makes its wy to the head after having supplied the gonad. The linow spaces at the anterior and of the body are very limited, more so in fact than is indicated in the figures which have omitted the intrinsic museles of the digestive tract as well as retractors and protractors that attach to the body wall. However, the course that the blood takes in passing through the body proper differs in ne escential particular from that of $P$. hawaiensis.

The rompuseles are spinclle shaped (Plate 36, fig. 12) and the small densely staining muclens is superficially placed, in some eases being elevated above the surfiue of the slightly yollowish homogeneons cytoplasm.

In a prereding paper (Heath '(04) attertion has been called to the fact that in its mene important details, especially in the relations of the labio-buecal system, the nervens system of this species shows a striking similarity to the Chitons and rertain prowobranchs. The brain is relatively small and holds the usual position on the dorsal side of the phergnx behind the mouth eavity. As usual 
three pairs of nerves arise from its anterior borders and are distributed to the various structures of the atrial and body walls. From its lateral margins the lateral, pedal, and labio-buecal connectives arise side by side. The lateral present the ustal appeartuce as is also true of the pedal whose union with the pedal ganglia is marked by a well-develuped enlargement. In nearly all cases if not invariably the labio-buecal ganglia of the solenogastres are located near the openings of the pared rental salivary glands when these exist, and since in the present species these are situated far back the connectives imbedded in the muscular pharyngeal wall are elaracterized by a relatively great length. The ganglia imbedded in the wall of the pharyx give rise to three commissures and to the subradular connectives. The dorsal and ventral buceal commissures are sufficiently indieated (Plate 6, fig. 6) to require no farther comment. In one specimen, posibly both, a well-developed ganglionie enlatgement ocenrs on the rentral commissure and may eorespond to the buecal ganglion, the other larger ganglion with which it is in elose proximity and from which the subradular system is connected representing the labial. From this last named nerve mass another commissure passes ventral to the alimentary canal and in its course gives rise to two nerves which pass backward for a short distance and then become lost in the tisues of the pharymx.

As has been noted a typical subradular system is present in P. hawaiiensis. In Limifossor talpoideus it holds the customary position, but ganglia are apparently entirely absent. In one specimen of Strophomenia scandens rery small masses of ganglion cells seemingly represent the subradular ganglia of which no sign exists in the other specimen. In this speeies no well-defined subradular organ oceurs henee the ganglia are perhaps in a state of degencration.

Owing to the comparatively small size of the latero-pedal and pedal commissures they are not readily followed yet in certain places they have been traced in dissections and sections, so that so far as may be judged they exhibit no unusual features.

In the posterior part of the body the relations shown (Plate 13, fig. 2) exist. As there indieated the lateral and pedal ganglia are united by two strong connectives, and posteriorly give rise to several branches that pass lackward and become lost in the somatie musculature. From the middle of the suprarectal commissure a nerve arises that has been traced to the base of the dorso-terminal sense organ. This last named strueture (Plate 32, fig. 9) is protruded above the general level of the enticle. As indieated the cells are slender, naked, and rest upon a small aecumulation of what are probably ganglion cells. Nusele 
fibres attahing to tho base, are probably retractors, the pressure of the blood in the muderlying sinu being responsible for the protrusion of the organ.

the hermaphrolite glind lulds the usual position and anteriorly extends to a short distane behind the level of the union of the oesophagus and gut. In all the sperimens the sex elements are fully formed, some of the large ova having been dehisend and auried into the pericardial cavity. Posteriorly the undud gradually decreases in size finally passing into two long slender canals Hlat unite with the front end of the pericardium (Plate 13, fig. 2). This last named cavity communicates posteriorly with the coelomoducts that extend hackwarl a short distunce before proceeding forward. At first the epithelial lining of these canals consists of low cells similar to those bounding the pericardium, but these are soon replaced by others almost eubical in form supporting an abundance of long cilia that eontinue to the seminal receptacles. These latter organs amsint of from fifteen to eighteen sacs attached by short eiliated stalks to the gonoduct. In every case they were completely filled with spermatozuat.

The section of the coclomorluet, extending baekward from the seminal receptacles, is lined throughout with relatively high columnar cells filled with a darkly staning granular secretion. Immediately back of the seminal receptactes these are developed into several longitudinal folds that quiekly disappear more posteriorly. Still farther hackward the two ducts unite a short distance in front of their outlet and in this single eanal the internal folds reappear and persist to the eloameal "avity.

Immediately ventral to the outer opening of the reproductive system is a short diverticulum of the anterion wall of the eloata (Plate 13, fig. 2, dt). Its rolls are cubieal in form and essentially like those of the cloaca at this point, but there is mo sign of spirules or any secretion that indicates its possible use.

Strophomenia ophidiana, sp. nov.

One sperimm of this speries (Plate 1, fig. 2), attached to an alcyonarian coral, Acunthogurgu angustiftom, wats taken off the sonthem end of Honshu Istand, Japlan (Nta. 3755) in water $52-75$ fath. in depth. It measured $43 \mathrm{~mm}$. in length and 2.5 mm. through the thickest part of the body. The color is reamy white shatling to very light brown in the neighborhood of the head. I well-rlefimed dorsal semserengan is present of the usual type.

Thro cuticle is relatively thick, neasuring on an average $0.19 \mathrm{~mm}$, and rests upon a thin hypolemul layed whose constituents present no repeeially note- 
worthy features. The papillae are fairly numerous, especially ventrally where they projeet somewhat above the external surface of the body. Their slanpe and general character are represented in Plate 33, fig. 9. Sinall yellowish granules are seattered throughout the cuticle, but of their origin or function it is impossible to make any definite statements. The spines are shown (Plate 36, fig. 17).

The sensory atrium is exceptionally small (Plate 8, fig. 5) and the two outer ridges appear to be lacking altogether. The inner ridge, on the other hand, is clearly developed and typically placed but is of linited extent. The eirri in this genus are united as usual in groups of $2-5$ and are composed of the customary cubical pigmented cells. Posteriorly the atrium opens into the buceal-pharyngeal tube, a long slender structure of about the same ealibre throughout. Its lining is composed of slender epithelial cells produced into longitudinal folds especially in the anterior half. External to the epithelium is a well-developed layer of cireular museles and in contact with this a sheet of longitudinal fibres which become more abundant in the neighborhood of the stomach-intestine. In its anterior fourth this section of the digestive tract is attached to a considerable number of fibres which extend more or less radially to the body wall. Posterior to this region gland cells, arranged in small pear-shaped groups, are imbedded in the longitudinal muscle fibres and by intereellular canals open into the gut. The beautifully regular arrangement of these organs is shown (Plate 17, fig. 13).

Ordinarily the stomach-intestine conneets with the posterior end of the pharynx or oesophagus, but in the present species such is not the case, for this junction is considerably in front of the ventral salivary glands which are appendages of the pharyx. However the ventral wall of the gut from the dorsal intestinal coecum to the openings of the salivary duets and for an equal distanee posteriorly is elearly pharyngeal in character, lacking the hepatic cells but possessing the characteristic muscle layers.

The ventral salivary glands are relatively long tubular struetures penetrated eccentrically by a thin epithelial tube through which the outlying glandular cells open. Close to the outlet into the pharynx this glandular portion disappears, and the dolieate duct makes its way through the ventral side of the pharynx to open into a small cul de sac.

No radula is present.

The extent and relations of the anterior intectinal coefum are well represented (Plate 8, fig. 5) and the intestine conforms so closely to the usual type that 
it demands no description. Postriorly the gut narrows rapidly, beemes somewhat rectangular in cross section as it passes between the limbs of the shell gland, and shortly lyofore its ontlet in the cloara develops moderately high folds.

The pericardial "avity is of very large size (Plate 18, figs. 2, 3), and the contained leart is of the usual greatly elongated type. There are no distinet signs of a division into andele and vontriele though a valve-like flap near its anterior eud may indieate such or possibly the commenement of the aorta, which for a (onsiderable clistance is of as great diameter as the heart itself and even in the lead reagiou continues of lauge calibre (Plate 18, fig. 1). Its relations to the gomad and visceral cavity are similar to what oecurs in S. triungularis. In the posterior part of the body the channels are more than usually ill defined, but the coulse of the blood is exsentially the same as in the other speries of the genus. The corpuscles possess the characteristic elliptical or pointed ovate form, and are accompanied by a relatively large number of lencocytes.

The gonad is fully developed, of relatively laree size and the sex products are arranged in the customary fashion. Throughout its entire extent, but especially in the posterior half of the animal, the normal reproductive elements are associated with large masses of eggs in all stages of degeneration. This may be due to post mortem changes, but the sharply defined character of the various stages of the spermatozoa, ova, blood corpuscles, and other collular elements in various parts of the body argues against such a view. In some species of Chitons (e.g. Ischnochiton maydulenensis) a considerable number of ova do not pass to the exterior during the ege-laying process, but undergo disintegration and are alsorbed. Appearances indicate that this is the state of affairs in the present species, and the almost empty condition of the seminal receptacles further indieates that the breoding season has passed.

The ducts leading from the perieardial eavity are relatively slender though they enlarge somewhat before entering the shell gland, and as the cells change from a cubieal to a columnar form they become increasingly glandular. An unususlly large number of seminal vesicles are present, twenty-three oceurring on the side of the body represented (Plate 9, fig. 1). In these the distal, usually vesicular portion is exceptionally small (Plate 18, fig. 4) but the diameter may be sonewhat increasod when the organs are filled with sperms. These bodies are attached not only to the forwand end of the shell gland but reveral of them open into the dorsal section of the gonoduct. The component eells are columnar and show at various points faint signs of glandular artivity. The shell gland on the other hand is highly glandular, more than usually irregular in ontline and as 
usual in the genus unites with its fellow of the opposite side so elose to the rloacra that two openings appear to be present. The cells are all of columnar form and are of one type judging from the darkly staining granular secretion. As in other species of the genus a diverticulum of the eloacal wall is present ventral to the outlet of the shell gland, but there are no inclications that it is of any especial significance.

In the other species of the genus Strophomenia described in the present paper there are from few to many diverticula extending outwarlly from the cloacal wall, but they never reach the excessive development existing in this species. These are shown, somewhat diagrammatically (Plate 9, fig. 1). The cells are usually columnar and are filled with a fincly granular substance which in various places is in the act of escaping into the cloacal cavity.

The brain, clearly bilobed, is located against the under side of the intestinal coecum at the level of the posterior border of the atrum (Plate 8, fig. 5). From it the usual three pairs of nerves originate, that after branching mite with ganglionic masses attached to the bases of the cirri or without such union pass to the body wall. The connectives to the lateral, pedal, and labio-buecal systems arise in the customary situations and the relations of the ganglia themselves, so far as they have been determined, are typical. Pedal commissures and latero-pedal connectives occur at frecuent, though not perfectly regular, intervals and a corresponding number of unusually heary neves arise from the dorsal surface of the lateral ganglia. These have in several cases been followed close to the mid dorsal line but that they form commissures is not assured. They probably innervate the neighboring somatic musculature and hypodermis.

Posteriorly the pedal cords, united by commissures to the anterior cloacal wall, branch repeatedly in this last named locality and innervate the body and cloacal walls and some of the fibres become imbedded in the shell gland. The lateral cords at this same level likewise branch repeatedly and supply the same structures as the pedal, though more dorsally, and in addition give off a few small nerves that attach themselves to the perieardial wall. A very few branches from these last named nerves have been traeed a short distance into the heart. The pedal and lateral cords are posteriorly united by one delieate branch; others may exist, but the nerves are not sufficiently differentiated from the surrounding tissue to permit of their being followed for any ensiderable distance. It is a peculiar fact that no trace of a dorsal posterior commissure uniting the lateral cords has been found to exist.

The labio-bucal connectives arise to the inside of the connectives leading 
to the pedial ganglia, and at first resting upon the digestive tract and more posterioply inbedded betwern the pharyngeal glands may be distinetly followed to well-dofined ganglia in the neighlorhood of the outlets of the ventral salivary glands. Owing to the fact that these ganglia are united by a large commissure dorsal to the ventral salivary glands, though ventral to the gut, they probably correjond to the labial ganglia. This commissure leads from the posterior ends of the nerve nasses which more anteriorly are united by two more nerves ventral to the pharynx. One of these is a simple commissure like the more posterior one and like it is imbedded in muscles. The remaining one, imbedded in the same manner, is of much smaller size and soon unites with two small ganglia resting against the pharyngeal musculature somewhat ventral to the labial ganglia. These smaller ganglia are united also by a slender commissure. C'omparing this system with what oeeurs in $P$. hawaiens is it is probable that they form a subradular system which as in Strophomenia scandens has persisted, though the sense organ itself has amost if not completely disappeared. The labial ganglia are united also by a dorsal commissure leading ont from their anterior surfaces. An unusual abnormality exists in this ppecies in the form of two labio-buceal connectives on one side. One of these is incomplete since it is formed by a branching of the usual connective opposite the middle of the anterior pedal gland outlet. The more ventral branch, larger than the dorsal, makes its way to the underside of the pharynx and close to the mid line pursues a course to the neighborhood of the labial ganglia whereupon it bends outward at a sharp angle and unites with its fellow at the anterior end of the ganglion.

\section{Strophomenia regularis, sp. nov.}

'This species is represented by the posterior end of one aninal that, however, is so characteristic as to leave no doubt regarding its relationships. It was fornd in the bottom of the jar containing speeimens of Dendronepthya (Spongodes) sp. and may therefore be considered to have come from the southern end of Honshu Istand, Japan (Sta. 3717) at a depth of 75-100 fathoms. The length of the fragment is $9 \mathrm{~mm}$. and the average dianeter $1 \mathrm{~mm}$. Its general outline is represented (Plate 26, fig. 8).

The comlenterate, with which this species was associated in the jar, was originally preserved in formalin that in decomponing had completely decalcified the fragment. It may be (learly seen (Plate 24, fig. 7), however, that for the most part the spicules are of the usual needle form and are accompanied by a relatively small number with trmucated bases, all being imbedded in a cuticular 
sheath $0.157 \mathrm{~mm}$. in thiekness on the side of the body. The hypodermis is very well preserved but presents no unusual features. Here and there, esperially at the bases of some of the papillae, it contains cells, sometimes arranged in groups of three, staining darkly and apparently glandular though no trace of any outlet is evident. The spieules retain their eonneetion with the matrix cells as long as they are imbedded in the cuticle (Plate 24, fig. 7). The enlarged portions of the papillae are relatively small, elosely crowded together at the surface and are attached to the hypodermis by elearly defined stalks containing a few spindle-shaped nuclei.

A well-defined dorsal sense organ is present, apparently of the usual type though the oblique direction of the seetions makes it somewhat difficult to determine its exact relations.

The foot is comparatively small, moderately ciliated, without any eavity, and extends to the cloaea. It is accompained by the usual glands whose appearance and relations are shown (Plate 24, figs. 9, 10).

The stomach-intestine presents the customary pouched appearance, and is lined with the ordinary glandular epithelium, changing to almost cubieal ciliated elements beneath the gonad. Nettle cells of some coelenterate host are distinguishable in the small amount of material in the digestive tract. In the neighborhood of the front end of the pericardium the intestine narrows, becomes eiliated throughout, more or less reetangular in eross section then passes into a more tubular division which in its terminal seetion again expands and opens together with the gonoduets into the cloacal eavity.

As may be seen (Plate 24, figs. 9, 10) the perieardium in this speeies is of considerable size, and the presence of numerous musele fibres passing from its walls to those of the body indieates that it probably undergoes considerable variation in this respect, probably while driving the sex products into the gonoduets. The heart, distended with blood, is a well-developed organ and comprises two divisions, an auricle and ventriele presumably. The walls of the auriele are somewhat more dense than those of the ventricle but otherwise their relations to the incurrent and exeurrent blood streams are of the well-known type. The blood corpuseles are represented (Plate 24, fig. 14).

In its general relations the posterior portion of the nervous system resembles that of other species of the genus (Plate 26, fig. 8). The pedal cords, eonnected by numerous commissures, continue of about the same calibre until they reach the region of the cloaca. Here they enlarge very slightly, give rise to two or three strong connetives and as many smaller commissures, and then gradually 
become smaller, disappearing after breaking up into a small number of branches that hereme lost anomg the somative maseles. The lateral cords, on the other hand, alatge as they approate the posterion end of the periondium where they form at well-defined gamglion. Fom it eonnertives, of at least twice the diametor of those more anterion, pass to the pedal cords. The usual commissure passes dorisal to the gut; while posteriorly two on thee nerves make their way into the somatio nulseulature, and one unites with at shatply defined ganglion from which brancluses arise whose subdivisions are distributed over the aloaca and the borly wall of the sane region. In this species the nerves destined to the dorsal sense orgath are two in $n$ mmber. They arise, widely separated from cach other, from the dorsal commissure, and passing along the dorsal side of the animal reach the base of the sense orgath. In the present specimen one of the nerves for a considerable distanee traverses fhe sims entering the posterior end of the heart.

As is generally the ease with the genus the halves of the gonad are relatively wide atpart in the posterior part of the lody, being separated by a correspondingly wide blood sinus, and more posterionly they shade gradually into the pericardium. from this latter cavity the gonoducts arise as relatively wide tubes of fairly even calibre lined with cubical ciliated cells without any marked signs of glandulare activity. It the mion of the dorsal section of the gonoduct with the ventral part or shell gland a number of seminal receptacles are attacbed, twelve being present on the side of the body represented (Plate 26, fig. 8).

As may be seen these are of varying size and are attached by short statks (Plate 24, fig. 10). In the present specimen developing ova are present in considerable numbers, and a few ane free in the arity of the gonad; on the other hand spermatozoa ase of rare ocenrence. Howeser, in the dorsat section of the gonoluct adjacent to the receptades, and in the receptacles themselves sperms are abundant without any definite aldangenent or in some of the receptacles attached by their heads to the walls (Plate 24, fig. 13). Muscle fibres, attached at various points to the outer walls of these reservoirs and on the other band to the body wall, pericardium or shell gland, probably cause the dilation of these organs, while a delicate cuticular sheath to which the lining epithelium is attached may be responsible in part for their contration. The shell gland, from side view, is somewhat irregular in outline but in eross section is very symmetrieal (Plate 24, fig. 9). Its walte are of only moderate thicknesis and at most levels the homen is a narow slit. Throughout five sixths of its extent the cells, high and columnar in form, are moderately filled with a finely granular 
secretion that stains intensely and in this form makes its escaipe. In the posterior sixth the rells are of essentially the same form, lut their contents stain a faint pink. As moted alove the rectum opens with the halves of the shell gland into a shallow depression on the forward wall of the cloacat.

\section{Strophomenia farcimen, sp. unv.}

Two specimens of this species were collected off the southern end of IIonshu Island, Japan (Sta. 3748), at a depth of 73-200 fathoms. One was attached to a colony of the aleyonatrian, Aconthogorgin angustiflora; tho other was likewise clinging to a mass of a species of Dendronepthya (Ajonngodes). The langth of the type specimen (Plate 1, fig. 1) is 18 mm., width $2 \mathrm{~mm}$. The color in formaldehyde is ereamy white. A well-defined dorsal sense organ is present. From external view the outlet of the anterior pedal gland is no wider than the ventral furrow generally which is continuous with the cloaca.

The cuticle, approximatcly one tenth the thickness of the total body width, rests upon a hypodermal layer of unusual thinness (Plate 33, fig. 2), and is composed of minute elements most unfavorable for study. The papillate are of moderate size, and ane attached to long fibrons stalks containing 3-5 numele and at the surface of the cuticle are elonely crowded together. At the junction of the stalk and cliated portion as many ats 5-9 nuclei may oecur in a given section; the remainder of the dilation is filled with nuncrous small greenish yellow granules. The ordinary type of spicule, necdle-like (Plate 17, fig. 17), forms 5-7 layers, while the second type, usually with more truncated base and more curved acute tip, is located more at right angles to the hypodermal layer. It is worthy of mote that the somatic musculature is exceptionally thin, the plump rounded appearance of the speciment in hand being due to the firm consistency of the cuticle.

The anterior pedal gland, holding a position from the atrium to the hinder border of the erypt-like outlet, is composed of lobules of small cells tilled with a faintly or darkly staining secretion according to the stage of its development. The ductules make their way through intercellular spaces into the forward end of the pedal furrow, which is comparatively small and in cross section usually presents the appearance represented (Plate 17, fig. 11). Near its anterior border the foot originates as a high slender fold and extends to the cloaca. Unlike most species the cells of the posterior pedal gland open not only into the bottom of the pedal furrow but also between the cells of the foot, which is provided also with considerable numbers of gland cells. 
In several inportant partinalars the digestive eanal of the present speeies resembles that of other menbers of strophomenia. The at rial ridges are, as usual, two in number and enclose the oirme area; the more external is horseshor-shaped and is composed of slender columnar, ciliated rells which contain spindle-slatped mudei and a very small anount of pigment. Extemal to the outer one is a low ridge of somewhat similar cells which, as in P. hawaiensis, rests upun a rod-like mass of ganglion cells. The cirrose area is rather small in extent (Plate 7, fig. 1), and the finger-like processes, anding separatcly from the lounding wall, are composed of the usual pigmented cells, internally limiting an exeeedingly sender carity penetrated basally at least by delicate strands of comeetive tissue and probably nerve fibres. The opening from this sensory atrimm into the succeding portion of the gut is bounded by a ring-like fold, which is probably capable of protrusion to the exterior as it is supplied with numerous muscle fibres. Beyond this proboseis the pharynx pursues its way for a distance almost as great as in Strophomenia seundens. In the early part of its course its lumen is small, owing to the heavy folds developed in its walls (Plate 17, fig. 11), but more posteriorly, and especially in the neighborhood of the radula, it hecomes a canal of greater size. As far posteriorly as the forward end of the radula its walls are supplied with numerous glands, consisting of many smill, pyriform cells, united into bundles by means of eonnective-tissue fibres, opening probably by separate intercellular erevices into the pharyngeal cavity. In the neighborhood of the opening of the radula sae the eanal, probably to be considered as the oesophagus, again namows, and its walls, eomposed of high columnar cells, become developed into high ridges extending nearly to the centre of the lumen.

The radula is well developed and typieally located, but the teeth composing it are thin and delicate, since the seetions display few traces of displacement owing to the sectioning proeess. In eross sections it is very diffieult to determine the exact number of teeth, but there appear to be fifteen rows of from 24-28 in each row each having the form represented in (Plate 34, fig. 15). The basement membrane is continuous across the mid line, but the bases of the teeth are so fused that at first sight the radula appears to be of the distichous type.

The dorsal intestinal coecum is of great length, as in strophomenia scandens, and is filled, as is the gut, by vast numbers of what appear to be partially digested nematoeysts. In a few places ova, probably rasped from the tissues of the host, oecur within the food mass. The cells lining the intestinal tract are highly vanuolated and difficult to dearly define. The gut pouches likewise lack the 
usual regularity of other Neomeniina and frequently present a more than usually complieated appearance in eross section. In the posterior end of the body the gut uarrows, and becoming triangular (Plate 17, figs, 14, 15), passes between the cloacal passage and finally beeming reduced to a small, apparently eiliated canal it opens together with the coelomoduets into a depression in the anterior cloacal wall.

The ventral salivary glands are long tubular bodies opening into the pharymgeal cavity on each side of the radula (Plate 17, fig. 16). In their proximal portions they are delicate thin walled canals lacking any signs of glandulan activity; more distally these tubes eontinue in an unchanged condition, but each beeomes enveloped excentrieally in a mass of gland cells. These elcments are pyriform, filled with a finely gramular, lavender colored secrotion, which makes its way into the duet by means of ductules opening through intercellular eanals.

The heart is of relatively great length, and, with the exception of a few irregular outpouehings near its posterior extremity, is tubular throughout. There is thus no elearly defined auriele and ventricle nor line of demareation between it and the aorta. This last named ressel is of exceptionally large calibre, but its relation to the gonad and its route into the perivisceral sinus are normal. This last named space, owing to the unusually small number of muscle bundles binding the gut to the body wall, is of large size, but the course of the included blood into the median pedal sinus and posteriorly into the heart are typical. The blood corpuseles are thin, plate-like bodies, usually like a spearhead in shape, and rather closely resemble those of strophomenia scandens.

The nervous system, as it is not especially faroralle for study, has loeen studied in a general way only, but sufficiently to indicate that it is not essentially different in this regard from other species of the genus.

The gonad extends as far forward as the radula where its halves are widely separated by the large aorta, but more posteriorly they come in contact beneatt this vessel. The animals are dioecious and the sex cells are developed normally. The eoclomoducts take their origin from the extreme posterior border of the pericardium (Plate 11, fig. 4) in the form of comparatively thin walled tubes in which the lining epithelium is low and seemingly ciliated. Extending anteriorly this dorsal division of the cloacal passage unites with the ventral section about the level of the anterior end of the perieardial carity. At the intersection of these two divisions upwards of nineteen seminal receptacles are attachod, in appearance and arrangement closely resembling those in Strophomenia scandens. 
liatele romsists of a more or less pyriform sale with walls of median thickness to which the spermatomat ate attached in large numbers. In the ventral section, (1) slell ghluml, the walls are not so thick as is usual with the majority of Neomoniina and the contral carvity is of greater size (Plate 17, fig. 15). The component allo ans long and contain multitudes of spherical gramules staining intensely with hamatoxylin. Posterionly the halves of these glands do not unite with each other or at least not to any marked extent but open separately, though close together (Plate 17, tig. 12), into at shallow depression in the anterior cloatcal watl into which the rectum opens also. Immediately ventral to this depresion there is an outpushing of the wall of the cloara, that thus holds the same position as the diverticulum in Strophomeniu scamdens, but it is much more shatlow and mot so completely closed. The walls of the cloaca latek any folds of definite arrangensent, but at three or four points bear slender linger-like ontponrlings though without any special moditieations to indioate their possible function.

Strophomenia spinosa, ip. In'v.

Five sperimens of this speries were taken in southern Japan in the neighLorhond of Misaki ( 4 from Sta. 4935 - 6 and 1 from Sta. 37.48) at a depth of 73 -

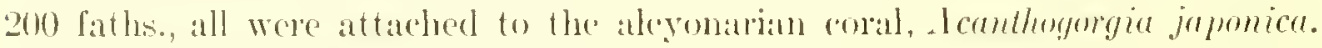
Extronally the appeatance of these animals diffors to a greater degree than in any other species dereribed in the present paper. As may be seen (Plate 1, tig. 3) some (the larger) specimens are almost inooth, while others present such a highly spinose appearance that at the onteet they were supposed to be distinet sperios.' Hore and there sertions show that some of the great spines ordinarily protruling almost at a right angle above the colliche have bern withdrawn so that their hatses invalde the territory of the somatio musculature (Plate 33, lig. 7); and it appeatro probable that this speredes is able to protrude or withdraw these spines and pessibly alapt itself to a shifting habitat as Echinomenia corallophita is known to do. The Jongth of the fody is appoxinately $28 \mathrm{~mm}$. with an

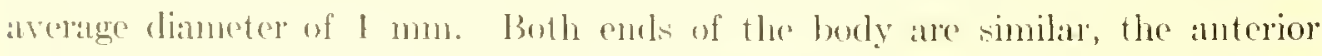
being distinguished usually by its slightly groater thinkness. The color is grayislı white.

The cuticle, 0.1 mme in thirkness (I'late 33, fig. 7), is in reality rather seant

${ }^{1}$ It is possible that these lifferences in externat alpenariness arr of specifie value, and that we are (lasting with fwo distinet forms. Plate 34 , figs, $, 4,9,10$, show differences in the ravlulae, and in the

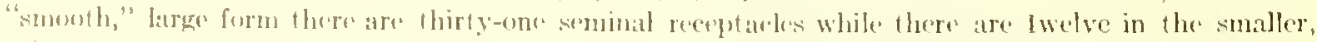

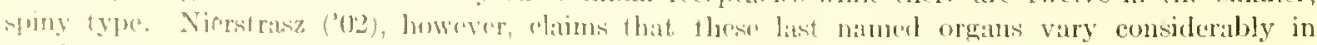
number in the same speries. Adelitional material is necessary to sottle the question. 
in amount, forming as it does seareely more than a thin sheall allout the inmumerable spicules imbedded in it. The latter structures atre of two varjeties shown (Plate 36, fig. 16), the larger being directed l'adially.

The hypodernis, eomparatively thin and not esjeeially favorablo for study, comprises so far as determined the usual types of cells. Those responsible for" the development of the needle-shaped spine retain their attanhent with it so long as the spieule remains in the cuticle. The formation of the spines with truneated base has not been followed, but in later stages each rests upon at small knob, probably the remains of a matrix cell, and as noted previons ly nay be withdrawn deep into the somatic musenature. This appears to be a momal process for as noted in a previous paragraph some specinucus ane wnother extermally than others; but the meehanim by which this is cffected is by mo moans clear since in a few eases only do museles attach to the base of the spine. The papillate are few in number.

The anterior pedal gland is a moderitely developed organ extending from the level of the brain to the posterior border of its ontlet into the pedal furmow. The cells are of the usual pyriforn type and eontain a secretion staining inky black with haematoxylin. The outlot is a simple sac-like indentation (Hate 8 , fig. 2, and Plate 11, fig. 2), highly ciliated, with the foot splunging as at welldeveloped fold from its dorsal wall. The cells of the pesterior pedial gland are umsually numerous anteriorly and save that they are of a somploat smaller size are not to be distinguished from those of the anterior pedal gland with which they are continuous. Posteriorly the furrow is continuous with the cloacal chamber.

The opening of the sensory atrium, subteminal in position, in companationy wide, and as may be seen (Plate 11, fig. 2 and Plate 8, lig. 2), the atrium itsolf is imperfectly separated from the succeeding section of the gut. As usult then pairs of sensory ridges are present, the two bounding the cirrose area being well defined while the remaining more exterion one is only faintly ontlined. The first two mentioned are comparatively low, not penctrated by blomel simuses, but by conncetive tissue and muscle fibres and at very few nerve filmes fom neighboring ganglia. The cirri are stender, compact budies united in groups of $3-6$.

The mouth, a relatively wide opening, leads into a tube of great length, lut of much the same size and appearance throughout its course. Its cpithelial

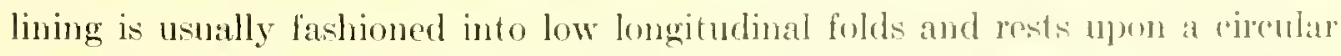
muscle layer of moderate thickness external to which are a few longitudimal hands 
and ladial fihros attanding to the body wall. As may he seen in Plate 8, fig. 2, munnerans pyiform masses of cells attach to the pharyux throughout its entire cxtent and pour the secrotion into the digestive eanal through numerous interrellular openings. The ventral salivary glands are long tubulur bodies with a very scmder duet though which the attached gland cells pour their secretion. Theor openings into the pharynx are exceedingly narrow but oceur in normal purition at the sides of the radula (Plate 17, fig. 4). The long dorial coecum, the fairly regularly pouched mid gut, and the relations of the rectum are all typic:al.

Tho radula is evidently in a highly degenerate condition, and differs consirlerably in different sperimens. In the individual represented (Plate 34, fig. 8), it is excesdingly minute and appears to be clearly monoserial. In Plate $\mathbf{3 4}$ figs. 8,9 , it is considerably larger, biserial and the teeth next the median line are noticealbly smaller than the others. Julging from the specimen possessing the larger radula (Plate 34, fig. 10), there are eight transverse rows.

The heart is the usual long, tubular organ represented in eross section (Plate 17, fig. 5) and the other features of the circulatory system are so typical of the gemus that they resuire no further comment. The corjuscles are very similar in outline to the spines of Limifossm talpoideus, being pointed ovate in shape. The mucleus is superficially placed, and may protrude somewhat beyond the general level of the coll.

The gonad in its position and the development of the sex products is nomal; and its comnection with the pericardium is made, as usual with this gems, by means of canals of unusually large calibre (Plate 9, fig. 4). Posteriorly the pericardial wall is producel into two pouches, separated by the sinus entering the luart, which are continuous with the coelomoducts. The lateral surfaces of these pouches and the perieardial wall for some distance in front of them, and coperially the rockmoducts themselves as far as the seminal receptacles, are ciliated, the cont boing especially heavy in these last named tubes. Roughly the height of the cells of these regions is proportional to the thickness of the ciliated coat, runging from that or cubical elements in the pericardiam to those in the neighborhood of the seminal reseptacles where the ratio of height to thickness is allout 3:1. The larger cells are develoned into a few longitudinal folds and are endowed with a considerable degree of glandular activity.

The ventral section of the coelomoluct, or shell gland, is joined somewhat behind its anterior end by the dorsal section, and the blind sae thus developed serves for the attachment of a greater number of seminal receptacles than in any 
other species deseribed in the present paper. On the side represented (l'late $\mathbf{9}$, fig. 4), there are thirty-one and as may be seen these are of various sizes, ranging in diameter from $0.2 \mathrm{~mm}$. to one fourth this size. On the other hand it is to be noted that another speeimen from the same alcyonarian colony has but twelve receptacles (Plate 12, fig. 3). The cells composing these organs are unmsually litre and in many situations are greatly vacuolated. This latter peculiarity, however, may be due to the fixing fluid since at all points where spermatozoa are attached to the walls the cells are nore dense though of the same height at the others. The stalks conneeting the receptacles are comparatively short, lined with low cubical cells and usually open separately into the coelomoluct (Plate 17, fig. 5).

The shell ghand is nowise peruliar except that it is of somewhat greater diameter than usual and more irregulat in outhe. Its cells are columnar and are partially filled with a darkly staning secretion that has escaped into the lumen in eonsiderable quantities. It may be added that in specimens of this type ova oecur in the pericardial "avity and the breeding season is therefore at its height. As usual the halves of the shell gland are not elearly united, but with the reetum open together into the chaca.

\section{Strophomenia triangularis, sp. nov.}

Five specimens of this species were taken off the southern end of Honshu Island, Japan, two from Station 3716, two from Station 4935 and one from Station 4936 at depths of $65-125,103$ and 103 faths. respectively. The length of all is approximately $12 \mathrm{~mm}$. with a width of $1.6 \mathrm{~mm}$. The body is flattened ventrally, and the presence of a low broad keel extending along the clorsal side of the body and terminating about $1 \mathrm{~mm}$. from each extremity, gives the :nimal a trimgular appearance in cross seetion. Every specinnen is coiled in a close spiral (Plate 1, fig. 5) aromel the stem of an alcyonarian coral, Calicogorgia sp.

The color of preserved material is a dull grayish yellow. The opening into the atrium is subterminal, and is clearly separated from the ventral furm. The foot, a single fold, extends from the hinder wall of the anterior peclal gland outlet to the clotea. A dorso-teminal sense organ is present. The cuticle on the back and dorso-lateral surfaces measures $0.108 \mathrm{~mm}$. in lepth to twice this thickness on the ventral surface. In decalcified material the papillar extend more or less above the surface of the cuticle (Plate 33, fig. 1), but in an natural state these are so surrounded or overlaid by spicules that they are usually invisible in surface view. The outer enlarged portion of each papilla is relatively 
smatl though considerably latroce than in the catie of others, apparently younger

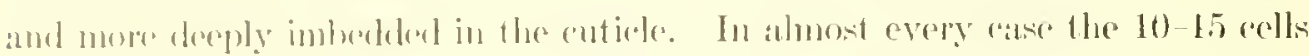
compriaing it ane contranted into a mass in eontant with the stalk that is very

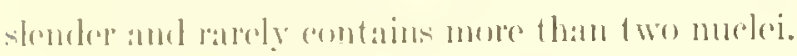

The sensory atrimm hokds the usial position (Plate 36, fig. (i) and eontains the watacteristie elements, of which the externat ridge entirely surpounds the atral ravity sabe posteriorly where it joins the internal ridge. This last named organ is likewiso rontinums aeross the mid line as a low ineonspieunus elevation which more postriorly horomes dereloped into a very shaply defined structure mithe with the onter ridge. The incheled area is beset with slender cirri, united into gromps of 35 is and composed of small cubical cells containing the usual yollowish pigment. In many eases muscle fibres pass up into the central "arity of atoh cirrus, and nerve fibres from neighboring ganglia may be traced to the hasat portion. The opening from the atrium into the next section of the digestive tract is on the posterion atrial wall and leads into a relatively long pharyeral tube developed internally into several longitudinal folds lined with a delicate conticle and composed of slenter columnar eells menally filled with some

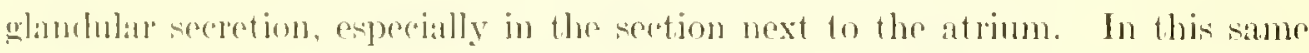
lourth gromps of redk (shown against uncler surfare of digestive tract, Plate 18 , fig. (i) appear in calch section attached to the couter surfiter of what is probably the buceal cpithelinum. Directly opposite the ontlet of the anterior pedal gland these elements, are in large measme replaced by others, likewise in gromps, and fillert with a darkly staining granular secotion or more posteriorly where they are larger, with a lighly vacuolated substane but litte afforted hy haematoxylin. These mbands cxtend backwated to the radula or at the point where the ventral salivary glands open. These last named organs are tubular, at feast $1.5 \mathrm{~mm}$. fong and $0.5 \mathrm{~mm}$. in average diameter, and open into depressions

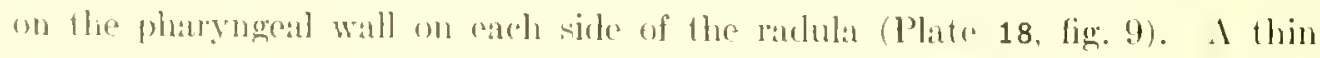
epithelial lining borders the lumen while the outres surface is in contact with

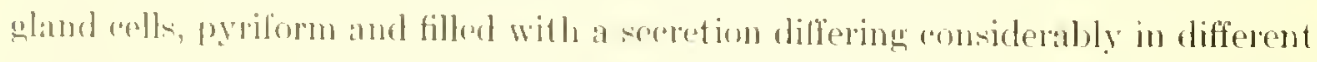
specomens and parts of the same gland. At some points the cells are rosely

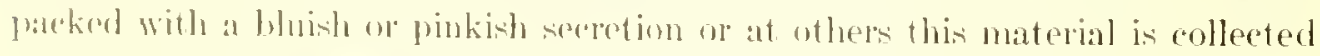

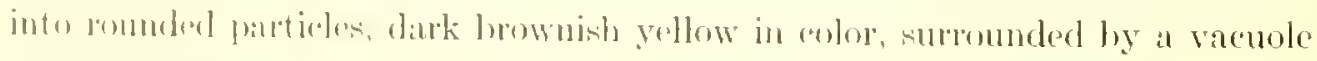
al romsiderable sizes.

The randula, typically located, seemingly belongs to the distichous type. and yet is reality reaterl to the polystichous form oceuring in other genera

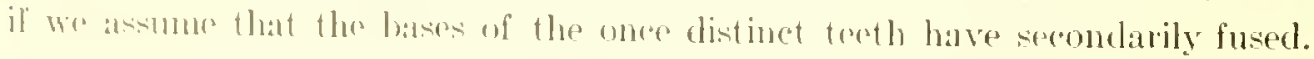


From transverse sections it appears that there are fifteen rows of teetlo whose general form is shown (Plate 34, fig. 4). They are thin and delieate, or at all events are not easily displaced in sectioning, and stain readily in haematoxylin.

As nsual with this gems the anterior intestinal eoecum is of great length and considerably in front of its union with the pharyx exhibits most of the essential characters of the stomach-intestine, possessing fairly regular outpouchings and an epithelial lining of the customary glandular type, but lacking the cubienl eiliated cells beneath the gonal. The coecum and most of the suereeding portions of the gut contain nettle and gem cells extracted from the host. Opposite the seminal receptacles the intestine narows, becoming gradually smaller until it opens into the cloaca (Plate 18, fig. 10). At the same time the dorsal ciliated epithelium gradually extends round the sicles of the rectum, finally meeting in the mid ventral line shortly in front of the anal opening.

The pericardial eavity in this speries is of very large size and the heart of nmusual length. The posterior division, however, is unusually small and peculiar in being paired, save at its junction with the ventricle with which it communieates by a single small pore apparently furnished with a valye. The aorta, at its origin, is of the same calibre as the ventricle and occupies the entire though narow space between the halves of the gonal. The branches, passing from it around the ventral and lateral surfaces of the gonad to unite with the viseral cavity, are likewise of large size and rery distinct. More anterorly these branches become much smaller and in the region of the head all but disappear in the present specimen. The course of the sinuses in the head, their union with the ventral sinus and the relation of the latter vessel with the heart are typical. The corpuscles are more than usually compact, but in their ellipsoidal form resemble those of other species of the genus.

The gonad extends as far forward as the radula and presents the usual features. Posteriorly it opens, in both specmens examined, by unusually large duets into the pericardiun, owing possibly to the fact that the time the animals were killed ova were present in considerable numbers in the perieardial cavity and along the cloacal passages. These canals, arising typically from the posterior end of the periondium (Plate 9, fig. 3), average approximately $0.095 \mathrm{~mm}$. in diameter and are lined with cubieal and low columnar rinhly ciliated rells. Toward the median line of the body these elements are more glandular and the secretion may direct the comse of the sperms.

The seminal receptacles, numbering 10-12, vary in size as may be seen (Plate 9, fig. 3), and possess unusually long stalks. Both vesicle and duct are 


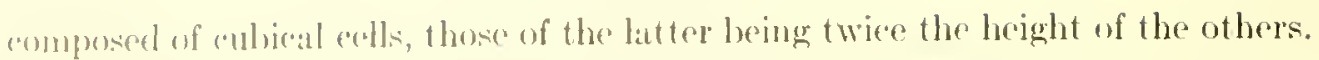
In the receptatele spermatozoal ane numerous and are attached by their heats to the watl.

"The anterior half of cateh ventral section of the cloacal passage (the shell grand) is (ommposed of colls of the appearanee represented (Plate 18, fig. S), filled whth a distinetly granular, darkly staining secretion. In the remaining half the appearanees are muth the same save that the glandular material is of a pink or rorldish color. The halves of the shell gland open into the eloaca by separate purs and a fold, distended with blood, separates in large measure these openings from that of the intestine.

The nervous system is typical in its general features. In the labio-buccal systom two commissures unite the ganglia ventral to the pharynx; one of these lwal's al pair of small ganglia as in strophomenia scandens (Plate 6, fig. 6). One commisure likewise pases clorsal to the pharyn. The relations of this system are essentially the same as in Plate 6, fig. 6, with the exeeption of the most posterin ventral commisure that appears to be lacking in the present species.

Lophomenia spiralis, sp. nuv.

This species, represented by two specimens (Plate 2, fig. 4), was taken in the vicinity of Nihau Island (Sta. 4176) at a depth of $537-672$ fath.; bottom, gray sand and foraminiforous mud; temp. $38.3 \mathrm{~F}$. Both individuals were (osely wrapped about the statk of a hydroid colony (C'ryptolaria operculata Nutting) and sections disclose the presence of nette and other eells in the allimentary canal from which we may infer that these foms, like Drepanomenia rampyrella, prey upon the polyps.

Both spereimens were of almost identically the same shape and size, measuring approxinately $24 \mathrm{~mm}$, in length and $1.5 \mathrm{~mm}$. in average diameter. Each end of the body terminates in a fairly sharp point but as the nouth is subterminal and surrounded hy well-developed lips it may readily be distinguished from the fousal opening that cxtends a short distanee on to the dorsal surface. The ventral furrow holds the nsual position, being continuous with the cloaca posteriorly ant in front terminating immodiately behind the atrial opening. In one individual where the pharynx was slightly retracted this groove appeared to lo dirently continums with the atrium but sections prove conclusively that such is not the case.

The opening of the perlal gland as usual oecupies the anterior end of the ventrul furrow, It: position, shape, and general appearance are aceurately rep- 
resented (Plate 6, fig. 5). The hypodernal cells bounding the cavity are higher and more slender than the usual type and are richly ciliated. Ill contain spindleshaped nuelei and lightly staining eytoplasm. Immediately behind the outlet of the anterior pedal gland the foot arises and extends to the opening of the cloaca. At the outset it is well developed but gradually decreases in size posteriorly until near the eloaea when it enlarges to twice its average size. A short distance behind its front end the hypodemal cells lateral to the base cease to develop spines and assume the form of a ridge (Plate 19, fig. 3) that inereasing slightly in size continues to the cloaca where each like the foot enlarges somewhat before disappearing. At all points the carity of the foot is rery suall, never spacious enough to permit the entrance of blood corpuseles.

The relations of the anterior section of the digestive tract are shown (Plate 6, fig. 5). Here the pharyux is somewhat protruded, but it is evident that the struetures borne on the buecal wall are not unlike those of the other Neomeniina hitherto described. Immediately within the lips the usual eiliated atrial ridge is present. However it is relatively short, its contained blood sinuses small and the component cells low and very slightly pigmented. This is also true of the inner elevation with the exception that in both specimens it is of somewhat greater height. The cirri of the inchded area are relatively slender and are usually attached separately to the buecal wall. Their cavities are of extremely small calibre and it is only in exceptional eases that the contained nerve fibre may be determined. Also their cell boundaries are indistinct, but otherwise these organs are not unlike those in Proneomenia hawaizensis.

The pharyux consists of two distinct portions, the first a relatively slender tube leading from the month into the second enlarged section that opens in turn into the stomach-intestine. Throughont the epithelial lining consists of cohmmar eells, forming at first low longitudinal ridges that gradually inerease in heiglt attaining their maximum size at the opening into the stomach.

At the junction of the first and second sections the pharyn is produced into a much folded diverticulum that affords an outlet for the dorsal walivary gland (Plate 6, fig. 5). This last named organ is relatively very roluminous, larger in fact than in most species of tolenogastres litherto deceribed. With the exception of two narrow lateral areas held by the anterior pedal gland it oceupies the dorsal surface of the digestive tract, and to a much less extent, the lateral borders between the brain and stomach-intestine. In the most favorable sections the component cells are clouly pyiform and are comeeted by a narow duct filled with granules that leats to the pharynx. some of the smaller colls 
are faily well fillow with small patplides which in the larger eclls are applied to the entl membane, the monining ontentis consisting apparently in life of a fluikl. In the majority of cases the nucleus is spherical, finely granular and eontains a distinet mucleolus.

The presition of the radula is shown in Plate 6, fig. 5, while a eross section of the radulat hale is represented (Plate 34, fig. 1). From these it will be seen that this organ helongs to the distichous tyle and that there are about twenty rews of teeth. While the shape of each tooth is sufficiently shown in the figures it is wortly of noto that in the radula tube the base of each tooth is connected ly a narrow cutionlar loridge. When the radula opens out into the pharynx (a) b plate appurars to split in half, at all events the exposed teeth in one specinen at lats are fully thece times farther apart than in the radula tube and they do not appear to be eomected hy a basal plate.

Immerliately in front of the rarlulat there is a pair of short diverticula of the pharyngeal wall which serve as outlets of the salivary secretion. The mass of Hhe outlying gland comprises several divisions bounded by connective tissue and horated (hiefly at the sides of the pharyx. The cells themselves are pyriform, highly vacumated and their ductules attach chiofly to the dorsal side of the main duct.

The stomach-intestine assumes its average cliameter at onee and gut pouches appeatr close to the anterior end. No forward coecum is present. The epithelial cells lining the tract at first form a flat surface but a short distance backward they herone arranged in the form of longitudinal folds (Plate 19, fig. 3) that continue to the neighlorhond of the accessory reproductive organs. In the lattere region the diameder of the intestine decreases, its lining walls are smooth, and werlged in between the cloaral passage and the perieardium, it makes its way to the cloara. The celle of the rectum are pear shaped with basally situated dence nuclai and the distal portions are swollen with a seeretion that in the form of a darkly staining fincly granulat mass fills the lumen of the gut.

In this species the provearlinn is long and the contained heart is relatively stender (late 8, fig. (i). The hloed from the posterior part of the body enters the hinder extremity of the heart which bere has the form of a very slender tube 1 Plate 19, fig. (9), attacherl to the dorsal wall of the pericardium. Nbout midway in the prescardial arity this canal enters another section, of four or five times

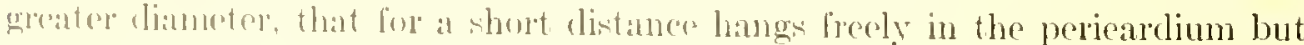
more antromerly unites with the periondial wall and with gradually diminishing califure holks this mation until it passes into the aorta. This latter vessel 
supplies the gonad in the usual way and in the hearl region breaks up into a system of sinuses that beeme continuous with the blood spaces lying at the sides and beneath the intestine. In the region of the aressong reproductive organs the lacumae become very circumseribed, hut so far as they have been traced they exhibit essentially the same relations as in P. hauraiensis. The corpuseles of this species (Plate 36, fig. 14) exhibit no features worthy of note.

The paired gonad extends forward to a point some distance behind the junetion of the pharynx and stomach-intestine. Posteriorly it ends abruptly slightly in front of the perieardium with which it is connected by two short duets. The arrangement of ova and sperms are the same as in the foregoing species. From the posterior end of the pericardial carjty the coelomoducts arise and proceeding forward (Plate 8, fig. 6, and Plate 9, fig. 5) almost horizontally unite with the shell gland. In one specimen the first section of these tubes is of small diameter and ill defined, while in the other it is well developed and is filled with spermatozoa that also crowel the perieardimn. In this same individual there is a cireumseribed area including the extreme posterior tip of the perieardial eavity and the neighboring section of the coelomoluet where numbers of spermatozoa are attached to the epithelial lining. Beyond this point for some distance the duct continues of small ealibre, with an epithelial lining composed ehiefly of goblet-shaped cells charged with a clear seeretion, and then suddenly terminates in a bub-like cnlargement that in tum unites with the seminal reeptacle and the slime gland proper. At first the rells in this swollen division are of greater height and more slender than those adjacent, and attach vast numbers of spermatozoa, but more anteriorly sex cells are lacking and the epithelimn consists of goblet-shaped elements like those just deseribed save that they are of larger size. The same type of cell also oceurs in the elongated seminal receptacle exeept at its distal end where the cells are lower, more compact and also attach large numbers of spermatozoa.

The ventral limbs of each coelomoduct extend hackward from the point of attachment of the seminal receptacle to a point a short distance in front of the cloaca where they unite and communicate with the exterior by a single opening. The epithelial lining in this part of the duct is relatively very high and gives evidence of forming two distinct secretions. The cells in the anterior third of the eanal are much vacuolated and contain a small amount of some faintly staining secretion. Nore posteriorly they gradually shade into more slender and elevated elements that, in the posterior half of the choacal passage, contain numerous granules densely crowded in their distal portions. Such 
molls an andined almost cxilusively to the ventral and lateral walls. The domal sille in both sporimons consists entirely of cells whose entire substance, with the exerption of at small basilly placed nucleus imbedded in a seant amount of protophlam. consists of at vacuolated homogeneous secretion staining like the muriparum colls of eretain gastropouds. It is possible that such a secretion is due to the transformation of products similar to those of the ventral granular ("slls, lut there is no trustworthy evidence that such is the case.

() cach side of the ventral furrow immediately in front of the cloaeal openIng are fwo indentations of the hypodermis each of which contains not less than fifty newlle-shaped spicules that are conly modifications of the spines produced in the aljawent territory. As is shown (Plate 19, fig. 5) they are direeted inward lowarl the mid line and sections show that multitudes of muscle fibres attach 10 the diverticulum chiefly on its blind extremity. Among the more prominent of these is at trinswerse band, another extending outwardy and attaching to the borly wall and, most prominent of all, numerous strands that pass in a postoro-lateral diretion and attach to the body wall slightly behind the level of the cloascal opening.

In its broadre features the nervous system of this species corresponds "losely to that of the other species described in this paper. The brain is of the orlimary hilobed type and is placed above the buceal cavity (Plate 6, fig. 5). Frem it six nerves arise that pasing forward and downward probably innervate the bucal and body walls with the attendant sense organs. The relations of the pedal, lateral, and bucal connectives also conform to the usual type. The last named cord is excedingly difficult to follow owing to its almost exact resemblane to the dense masses of muscle and comnective tissue that aceompany it, hut with high magnification it may be trared to the elongated ganglia placed at the sides of the radula and a little below it. The commissure attaching to the posteriore conds of the gangliat paseres dorsal to the radula. No clearly defined culmadular organ (xists and no nerves or ganglia belonging to this system are present so far as it is pessible to judge from the material in hand.

The lateral cords, holling the customary position at the sides of the animal, pass batekwat through the body and finally teminate in ganglionic enlargemonts on ench side of the perieardium near the tip of the seminal reeptacle. The commissure minting them passes out from the hinder end of each ganglion and resceses dorsal to the intestine. One or two nerves also pass out from each chlarement, hut in the confued mase of muscle they have been traced but a slort distance. 
The pedal cords after traversing the body gradrally approateh cach other in the posterior end of the animal and terminate in two ganglionic masses on each side of the mid line a short distance in front of the two groups of spines that project into the rentral furrow. There are strong indications that these posterior ganglia are united by a commissure. Owing to the diflienties of observation no other pedal commissures bave been diseovered and for the same reason lateropedal comnectives bave not been found with certainty though at various points there are indications that sueh exist.

The posterior sense organ is located at the extreme linder end of the animal in the mid line. At this point the bypodermat cells, unchanged in appearance, approach near to the outer surface of the body and there becone continuous with a sensory epithelium composed of slender farly dense cells in which the elongated nuelej hold an almost median position (Plate 32, fig. 11). Over the exact centre of this area the cuticle is exceedingly thin but gradually increases in thickness as the outer limits of the organ are approached, and contains considerable numbers of small spines that in both specimens overareh the sensory cup. Numerous muscles and connective-tissue fibres attach to its under surface and in the meshwork thus formed blood corpuseles and nerve cells occur in moderate quantity, the latter probably eonnecting with branches from a strong nerve that may be followed into elose proximity to the posterior pallial eommissure.

\section{Alexandromenia agassizi, sp. nov.}

Six speeimens, one badly mutilated, of this species were dredged in 460 fathoms (Sta. 2992) near the Revillagigedo Isknds off the coast of Mexien. All save one, elinging to a fragment of some land plant (Plate 2, fig. 5), were unattached and nothing is known of their mode of life. The smallest specimen is yellowish white; the remainder, of larger size, are yellowish brown.

The largest individual meatures 25 mm. in length and 5 mm. in average diameter in the middle of the body; and of the five remaining specimens three are of about this same size. The smallest is in an uneontrated state and is $22 \mathrm{~mm}$. in length and $3 \mathrm{~mm}$. in average dianeter. As may be seen in Plate 2 , fig. 5, the head is not distinet, usually bhuntly pointed, and readily distinguishable from the posterior end where the borders of the cloneal opening are widely expanded, in one specimen expecially (Plate 5, fig. 5), exposing the gill plates, about $40 \mathrm{in} \mathrm{number.} \mathrm{A} \mathrm{dorsal} \mathrm{sense} \mathrm{organ} \mathrm{is} \mathrm{visible} \mathrm{in} \mathrm{sections} \mathrm{but} \mathrm{not}$ in surface view, 


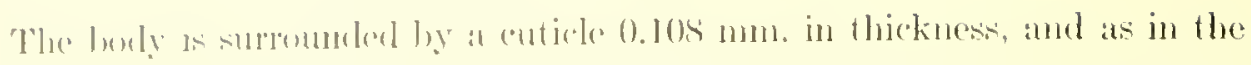

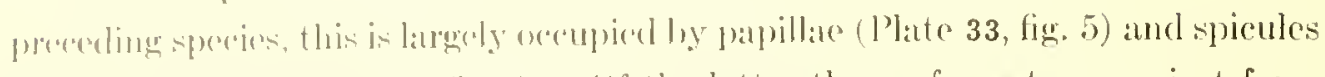

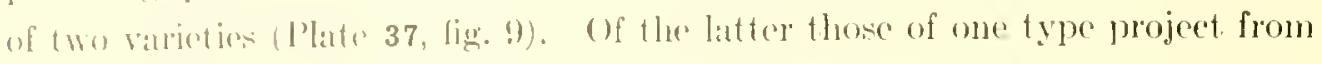
the hypulermis, with which they remain connereded, almost at right angles and protrute freely from the surfaer of the body. The others, needle-like, relatively small, and slightly corved, form from five to seven irregular layers ahnost at right amgles to the first named spines.

The patpillate alle fully ats numerous as in the sneceeding species and the constitumt colls ance appreximately half as abundant: but the differentiation interstalk and expanded patrt is mot so shanply defined (Plate 33, fig. 5). In many ratses the louse of the stalk is of gereat wielth and expands but slightly as the surface of the body is approached, the papilla in such circumstance having a clubshaped appeatrance. Even in the more typical forms the departure from such a state of affairs is not matied. The cells appean to be all of one type in the distat protion, at all events the nuclei alre of cusentially the same size, though they vary considerably in shape, and are surrounded ly mases of yellowish green pigment.

On the ventral surface, especially in the region of the mouth, ghand cells anderat in the hypulomis. In their early stages each is pear-shaped, the stalk leme inserted anonge the hypodernal cells, while the distal portion contains a lightly staining almost homogeneons seerotion. Later this product becomes more alsundant, swelling the coll to fwice its original size, and a granular mass appears to make its way ly a very dolicate pore to the exterior, though this has not heon demonstrated to my entire satisfaction.

The main portion of the anterim pedit ghand is located between its outlet inte the vontral furme and the radula and its supports. At this point the cells aro continuous acrose the mid line and lat cratly extend as thin plates compressed hetwern the body watl and the prodigious salivary glands (Plate 20, fig. 4). Pesteriong they separate into two groups which pass without any recognizable line of domaration into the posterior pedal gland. The eels composing it are of the unal pyriform type, densely filled with intensely staining secretory proluets, and are arranged into irregular groups or lobules. In the customary fathion the ductules from each coll open by an intercellular canal into the anterior cont of the pealal furrow.

It the point where the anterior pectal gland opens to the exterior the ventral groove becomes a deep (2xeavation (Ilate 7, fig. 3) the area of whose walls is increased lig the presenee of extensive dursu-lateral outpouchings and numerous bolds coursing from the rouf half way down the sides. On the posterior face 
sereral folds arise and posteriorly extend along the growe to the cloncal eavity. These are not constant for at their first appearance they aure eleven in number (Plate 20, fig. 9), soon decreasing to nine and gradually to five in the posterior half of the animal. Each is penctrated by a loose meshwork of muscle and connective-tissue fibres, through which the multitudinoms ductules of the pedal gland take their course, together with many corpuseles from the overlying simuses. The eomponent cells are high and colummar, cisecially the ontermost which contain small quantities of yellow pigment.

The opening into the atrium, holding its customaty subteminal position (Plate 7, fig. 3), leads into the atrial ravity whose walls are differentiated into the usual ridges (Mundleisten) and cirrose area. As in I'. hawaichsis the outermost ridge is accompanied throughout its anteriog half by a proninence, ill defined, and yet evidently sensury since it is composed of slender cells with basal muclei resting upon a rod-like group of ganglion cells. In the posterior half of the lips this structure becones more indistinct and finally blends indistinguishably with the outer atrial rirlge.

Of the two large atrial ridges the outer is of large size and skirts the cavity save on its posterior face. It is supported by an abundance of comnectivetissue fibres associated with a seant amount of muscle bands among which small blood sinuses make their way. The halves of the dorsal ridge arise independently of each other in the mid line on the roof of the atrial cavity. At fint very low they rapidly increase in height (Plate 20, fig. 1), but hehind gradually distppear in the neighborhood of the opening into the pharynx. Blood sinuses penetrate into their interior and probably in life inerease these organs to a very considerable degree. On each side of the mid line in front and hanging from the roof of the cavity are two pairs of large papillate springing from the outer and inner ridges respectively. The epithelial covering is eomposed of columnar aells whose distal half is filled with golden yellow pigment.

Each cirus arises independently as a finger-shaped process of the atrial wall with an average length of $0.3 \mathrm{mmn}$. It is composed of cells about twice at: high as wide, closely packed with yellow pigment, arringed about a central cavity within which it is occasionally possible to follow a nerve fibre.

The opening of the mouth into the pharyx is guarded by a circulat fold beyond which the eanal passes dorsally until in the neighborhood of the ralula where it bends at right angles and passes direetly backward to join the stomathintestine. Throughout its entire extent its internal lining is developed into many' folds, large and small, often exceedingly way and of most complieated appear- 


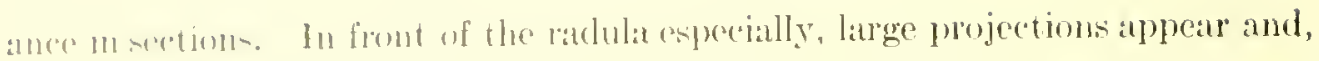
al. will be mome fully deseribed fresently, alford an ontlet for the two sets of salivaly phands. The chatracter of the pharymeal cpithelium undergoes minor modifications at varions points, but in general it may be said that the constituent colls range in sizo from cubical bodies to others three times as high as wide, are deroid of cilia and are hounded by a well-defined cuticular sheet.

The salivary ghands, which probalbly are homologons with the dorsal set in other Nommenina, atre in this speries remarkable for their size and extent. With the exerption of a fow seattered groups of eells the main portion is distributed in the form of a wide band encircling the pharyn from immediately behind the brain to the radula (Plate 7, fig. 3, ds). So far as may be determined from a single sperimen all the cells are peal-shaped and are grouped into chub-shaped dolules of various sizes. In the expanded part the cells are one layer thick and survound a central canal down which the ductules make their way to open by interecllular canals into the pharynx.

From transverse sections there are indieations that a portion of the gland located on the dorsal side of the pharyx immediatcly behind the brain differs in character from the remaining portion. The follicles are more slender than thone of aljoining regions and the glandular products in the early stages of their development are of lavender color and markedly different from the yellowin pink substance elsewhere. All the follicles of the dorsal salivary glands of whaterer character are supported by numerous museles forming the pharyngeal wall and by connective-tissue bands between which numerous blood sinuses are prescut.

The glands which probably correspond to the ventral salivary of other solenogastres although in this specios their outlet into the pharyux is somewhat more in front of the ratula than usual, are enormously developed. As may be sem (Plute 7, fig. 3, sg.) they extend from the brain to a point considerably behinel the radula where they contirely surround the alimentary canal and elsewhere overlap it to a very comsideralule degree. As in the dorsal group the gland is composed of thirk-walled follicles, of large size, and from each pyriform coll a ductule leads to its intercellular outlet. Owing to the great bulk of the lolulus and the remotenesis of the greater number from the main duet (leading into the pharyux) this latter canal is provided with numerous branches (Plate 26, fig. 9) which cone in rontact with the majority of the follieles where each ands blindly. These mins ducts are lined by an epithelium in which the cells are of two distinct typex. In the inner half, through which the duetules make 
their way, the colls are very high and slender and the rytoplasm varuolated. In the outer half the eelk are not over one third at higl and the frotoplasin is relatively compact.

As just noted the branching ducts of each side unite into a single tube, which opens into the bottom of a deep depression on the side of the pharynx. From the base of this pit a large conical papilla (Plate 36, fig. 10), whose surface is thrown into five or six circular folds, projects inward, in life its tip probalbly extending as far as the opening into the pharynx. It is practically solicl, consisting of connective tissue and several muscle filbres which probably act as retractors. The ductules of a very few adjacent follicles make their way into this protuberance and are accompanied by similar tubules from some of the dorsal salivary-gland eells. These slender canals make their exit at several points, from the tip and ly means of pores ventrally placed on the circular folds. The last named openings connect with small canals (perhaps one sixth the length of the eireumference of the fold), loeated between the cuticle covering the papilla and the underlying epithelium. There may be other exits but if so they are of small size and are invisible in the material in hand.

Attached to the pharynx, between these large glands (sg.) and the stomachintestine another extensive set ocours (Plate 7, fig. 3, and Plate 20, fig. 2) that are diffieult to homologize. They consist of numerous pyriform colls, highly vacuolated or containing masses of some secretion of a pinkish slade, arranged in the form of lobules bounded by musele and comnective-tissue fibres. The ductules pass to the pharyngeal epithelial lining through which they open by intercellular channels.

The radula is relatively small and is located on a fongue more than usually pointed. It is of the monoserial type (Plate 34, fig. 5) and as fall as may be determined from transverse sections, comprises between forty-five and fiftythree transverse rows. Each tooth is a narrow rectangular plate bent to form a very obtuse angle. The odontolulasts are of the isual colmmar type. The radula sae is supported by ten or fifteen pairs of large ecells, probally turgid in life, filled with a highly watery secretion, surrounded by connective tissue and muscle fibres. These last named elements are part of bands, ton complicated to allow of reconstruction, that attach to the pharyngeal wall, the raclula, or the sheath of the salivary glands.

The gonad, with the usual relations, extends from a short distanee posterior to the radula to within a short distance of the front end of the perieardial cavity. In common with other hermaphroditic solenogastres the organ in this species 


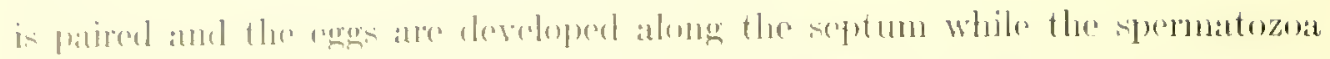

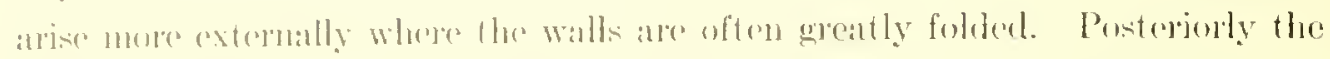

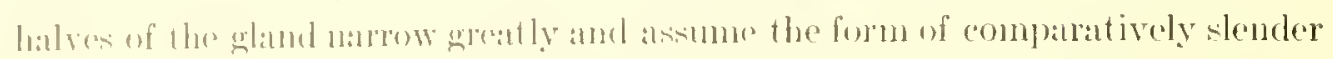

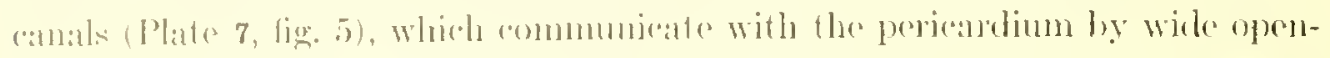

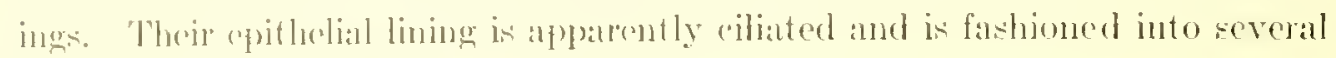
bur lomgiturinal ridgess.

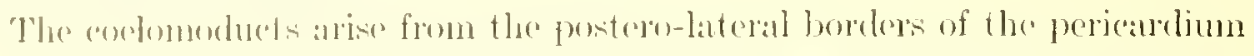

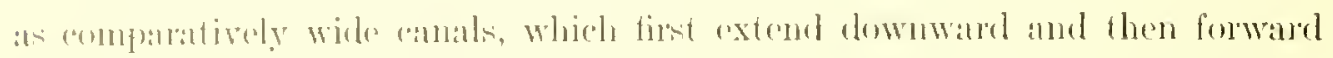

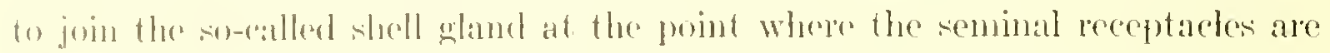
locatcol. As ustal the shell gland of one side joins the comerponding organ of the oflere and after namowing to a slonder tube opens into the cloaca in the mid line.

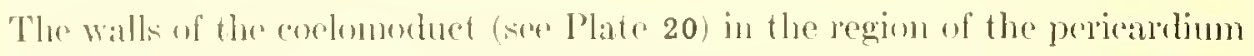
are comparatively thin, but one thind the distance to the seminal receptacte they lecome thicker, the colls more slentere and the tent to fifteen longitudinat folds more promounced, a statro of affairs which anntinues to the shell ghomd. ('ilia are certainly present at vanions points and it is probable that they exist

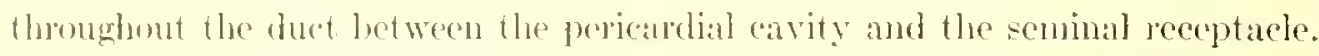

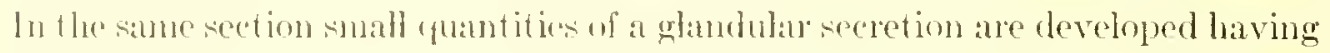
the form of minute grambles which show at first a distinctly acid reaction but after their diseharge berome mone or less confluent and alkaline. Minute fuantities of spermatozoal are also distributed throughout this same division of the duet.

In the single specinen cximnined the seminal receptarle is a small dise-

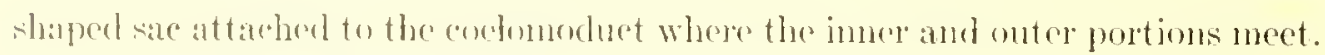
It is wedged betwern the berly musculature and the slell gland and the slit-like lummen contans a few spematozon only. The colls eomposing the walls are companatively low and are glandular, the cleatr secretion, small in amount,

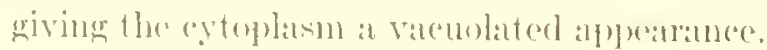

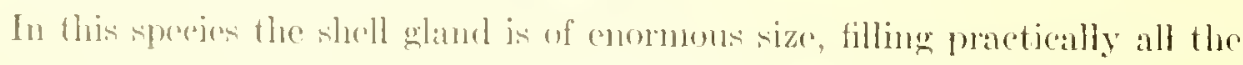

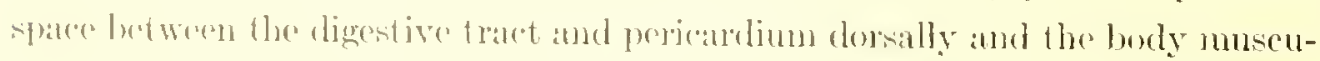
lature ventrally and laterably. Is figured, Plate 20, each half is penetrated by a duct, of allout the diameter of the foregoing section, through which the sectetion from the surponding ghandula portion makes its way. In the neighborhood of the aldacat these duets emorgr from the gland, wnite with each other, and forming an s-shaped loop in side view open into the eloaca by a very narrow pore. 
The eomponent gland cells are arrunged into numerous lobules, which generally extend from the surface of the gland to the main central duet. These are separated from each other by delicate connective-tistue sheaths, which frequently contain small blood sinuses, and ane traversed by a slender camal which apparently does not function as a duet. The evidence is not altogether conclusive but from a careful study of sections it appeas that the secretion does not pass through the carity of the lobule, but is contained in delicalte ductules which arise in the gland eells. Arriving at the central cavity of the gonoduet the darkly staining secretion makes its eseape through the lining epithelium by means of intereellukar openings.

The epithelium of the main duet is composed of high columnar cells which contain a finely gramular lightly staining glandular substance. About the teminal section of the coelomoduct, where the epithelimm become lower and the sceretion seant in anount, a heavy sheatl of circular muscles appears and contimues to the cloacal cavity.

As might be expected in an anmal of the size of this species the circulatory system is well developed and of more than ordiniry complexity owing to the large number of sinuses which hold positions in and around the valious systems. The heart, having the usual position, consists of two distinct divisions (Plate 7, fig. 5), an auricle and ventricle. The walls of both of these are of uncommon thickness, but otherwise present no especially noteworthy features. They are connected by a tubular stalk which projects slightly into the eavity of the ventricke and may serve as a valve.

From the front end of the ventricle blood passes through numerous openings in the somatic musculature to unite into one tube, the aorta, which from the outset appears to lack any trace of an endothelial lining. Is it courses forward dorsal to the reproductive ghand it originates numerous rescols which ranify through the body wall or passing ventrally between the halves of the gonad forms a subgenital sinus. In the head region it expands eonsiderably and communicates with extensive lacunae in and between the body wall and the alimentary canal. The blood in these spaces makes its way to the ventrat surface where it unites into one main canal, immediately ventral to the gut, which connects also with several small chamels coursing along the folds in the ventral furrow. At the posterior end of the hody this rentral simus courses dorsally, keeping close to the under surface of the gut, and when opposite the junction of the auricle and ventriele it divides into two short branches which pass backward on each side of the rectum. These last named ressels are very 


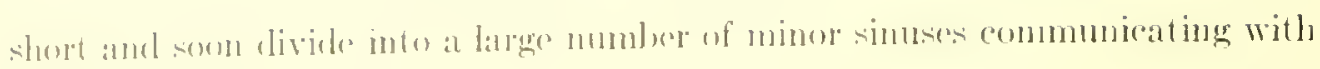
the gill folds.

Eareh enill plate in morely a ciliated fold of the rloaral wall with which it connects anteriony and laterally. Tho hlond enters the anterior border wsually,

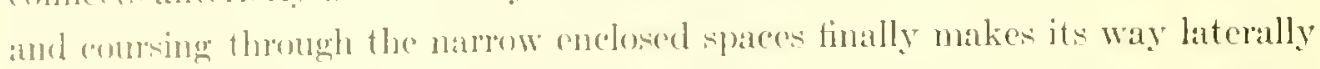
to the buly wall. llere it unites with other vestels of sinilan origin and funally

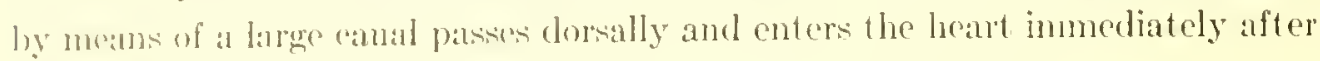
miting with the corresponding sinus from the other balf of the body.

The blowl corpuneles are spherieal bodies, $0074 \mathrm{~mm}$. in dismeter, hyaline in appearance and containing a suall, donse nucleus. The leueocytes are remarkany infrequent, unusually compat, but otherwise devoid of any noteworthy features.

Nhout the bases of the gills there are great acemmulations of gland cells (Plate 36, fig. 19) accupying spaces in the meshwork of muscle strands between the folds and the budy wall. They project somewhat into the sinus of each gill plate, and are oceasionally penetrated by blood sinures, but there is no trace of any outlet une is there any indieation of their possible function. Each cell is approxinately $0.01 \mathrm{~mm}$, in dianeter, and contains a small, spherical nucleus imbedded in slightly racmated, granular rytophasm.

The nervous systen of this species is in an exeellent state of preservation, and as the nerves in many parts of the body are more than usually well defined considerable attention has been devoted to this portion of the anatomy. The Iocation of the luain and principal ganglia are the same as in Dorymenia acuta for example, but in the listribution of certain of the nerves differenees appear which are here described. The brain (Plate 12, fig. 5) is relatively small, but anteriorly gives rise to the usual number of nerves distributed to the atrial cavity and the noighlwhing body wall. The unitod commectives of the lateral, pedal, and labiobuesal systems enter from the sule. The lirst two connectives become differentiated a short distanee laterally and pursue their usual eourse through the body. The labio-buceal connoctive springs from the lateral commective posterior to the union with the pulat and holds its contomary position at the sides of the pharyn.

In borymenia there is a large norve fibre arising from the anterior end of the latcral ganglion and is distributed to the procerebral ganglia about the bases of the cirri; in the present speeics it is totally lacking. In both species nerves arising from the podal ganglia are distributed to the walls of the pedal-gland outlet. Numerous connectives mite the lateral and pedal ganglia, and are far from boing regular, in secreral cases miting with neighboring connectives by 
delicate branches. Usually the most anterior connective is of the largest calibre, but in the present instance the first two or three are extremely tenuous, not ored one third the diameter of the succeeding commectives. Dorsal nerves from the lateral ganglia are numerous but in no instance have they been traced to the mid dorsal line.

The labio-buecal system is mobably more extensive than is shown in Plate 12 , fig. 5, for owing to the great width of the muscular pharyx and the abundance of salivary glands elosely crowded together it is very difficult to trace nerves for any considerable distance. The eomectives may be readily followed to the ganglia at the sides of the pharyux, and the commissure uniting these is as readily demonstrated, but a different state of affairs is met with elsewhere. Before uniting with the labio-buceal ganglia the comnectives far out on the external face of the salivary glands enter a ganglionic enlargenent on each side from which two nerves originate. One of small size disappears amost immediately among the glands; the other of much larger size passes in toward the mid line, but becomes lost in the darkly staining secretion of these same glands. From the dorsal side of each labio-buceal ganglion a small nerve arises that gradually extends to the lateral border of the pharynx which it crosses to form a commissure. At various points throughout this entire system exceedingly small nerves arise and probably innervate the neighboring regions but their destination is not ecrtain.

In the posterior end of the body the lateral nerves benome so crowded against the body wall, owing to the huge shell gland, that it has been imposille to trace conneetives in this region. Opposite the posterior end of the heart they expand greatly (Plate 12, fig. 6), and originate several nerves distributed more posteriorly as well as the suprarectal commissure. Two comectives, the posterior one of large size, unite with the posterior end of the pedal cords. In the mid line the suprarectal commissure develops a nerve that passes to the base of the dorso-terminal sense oran, to which it sends a small nerve, wherempon it proceeds backward distributing fibres to the dorsal gill plates. The large branches, springing more laterally from the posterio-lateral enlargements, braneh repeatedly and in many places dehicate offshouts lave been found entering the branchial folds. Plate 12, fig. 6 represents the more important of these whose number and origin is conectly shown though the branching is somewhat diagrammatic. With this exception the nerves and ganglia shown are reconstructed carefully from micrometric measurements.

The pedal ganglia have not been examined in the middle of the body, but 


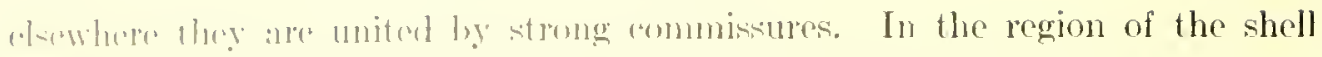

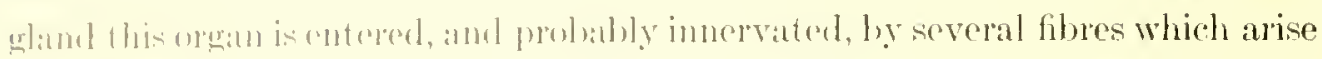

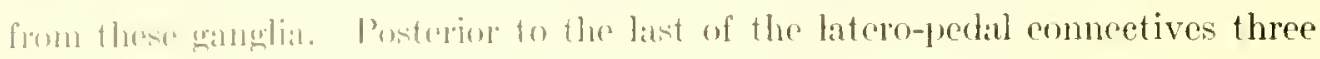

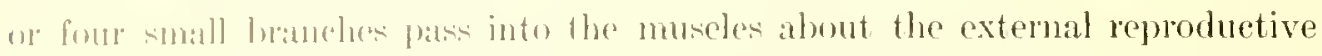

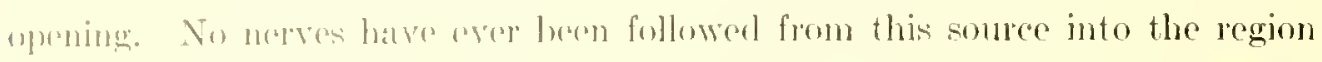

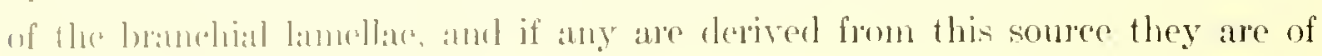
very sllall sizr.

Alexandromenia valida, s11. nov.

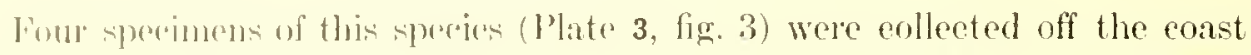
of soutlene ('allifornia from the following stations: 2980, 4382, 4389, 4391. The wheth ramger from 603-1350 fms and in every ase the bottom was gleen mul. All the suecimens were unattached so that nothing was learned of their labhits. The moisumenents of the largest specimen (Nta. 4359) are as follows:

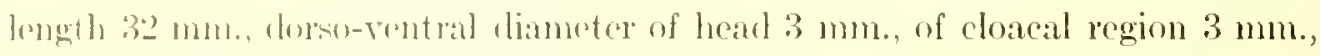
:I forage dianeter of body $3 . \overline{\mathrm{m}} \mathrm{mm}$.

Thu heall is mot distinct from the lody but is chaseterized by a more printext appeatrance than the posterion end, and in all the specimens the borders of the doand opening are slightly expanded, exposing, to a slight extent, the gill folds. The atrial oponing is relatively small and its formard border is almost level with the front ond of the smimal. I pedal furrow axtends along the vent ral surfates of the boly and posterinty becomes continuous with the eloacal cavity. Interiorly, for alwout 1 num. extent, it expands and allows the eseape of the anterion pockl syland seretion (Plate 21, figs. 2, 4) which, in the type, fills the opening and extonds posterionty some distance along the ventral furrom. The gencreal andor of the horly is light yellow.

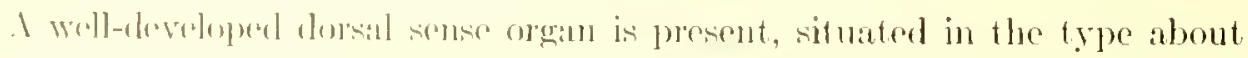

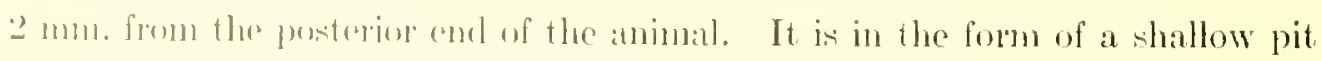

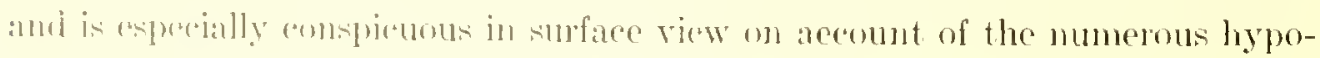
dermat papillate which surmoum it.

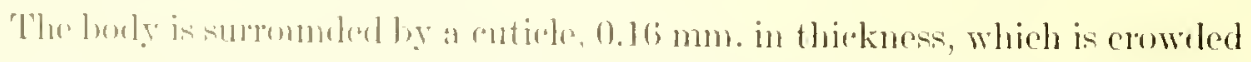

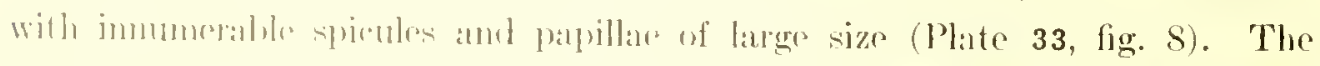

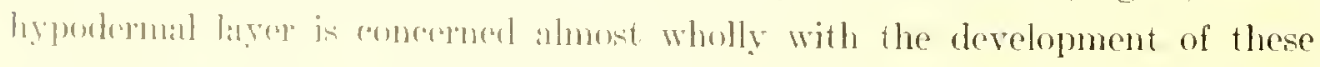
structures, the pention probsaldy responsible for the formation of the cutiele

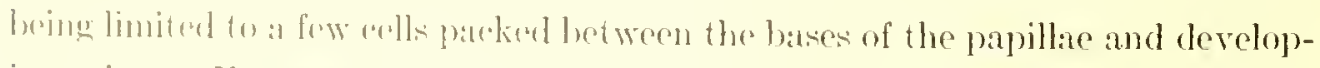

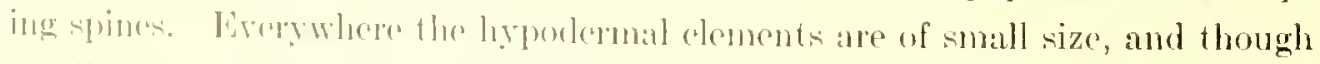

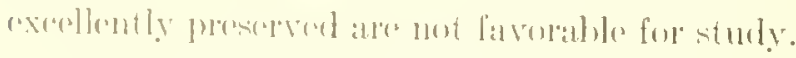

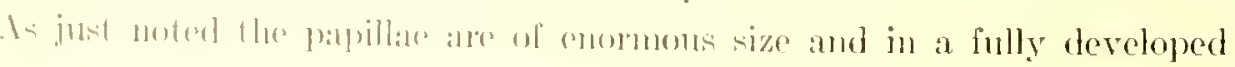


condition contain not less than 100 cells. Of these fully twenty-five are loeated in the stalk while the remainder hold positions in the expanded portion. This last named section is relatively compat and lack the spaces and pocudopodialike processes characteristic of the majority of Solenogastres. The cells composing it are of two distinct types, one containing small spherical dense nuche and another in which the mucle are of twice the diameter of the first, and stain hut faintly in haematoxylin. The cell boundaries are invisible and it is eonsequently impossible to determine if these differenues are eorrelated with others. The colls with the small unclei eontain a few relatively lage yellowish pigment gramules, and there is some evidenee, thomgh not wholly conchusive, that this secretion is absent from the cells of the remaining type.

Of the two kinds of spicules the larger $(0.189 \mathrm{~mm}$. long) projects from the hypodermis ahmost at right angles and its pointed extremity projeets slightly above the surface of the body. Is Plate 37, fig. 11 shows these spienles are hollow and remain constantly in contact with their matrix cells, which are several in number and in their general appearance and relations are not unlike those of $P$. hawainensis.

The second type of spine is many times more numerous than the one just deseribed. Over the body generally all are of essentially the same size $(0.135 \mathrm{~mm}$. average length) and in their needle-like appearance rosemble the long spines of Proneomenia, Strophomenia, ete, with which they are probably homologous. Without any very definite arrangement they form several layers parallel with the hypodermis.

The anterior pedal gland oecupies practically all the space between the body and pharyngeal walls between the brain and the radula. The cells are of various sizes but average $0.159 \mathrm{~mm}$. in diameter and are so densely filled with secretory products that all other elements of the coll are invisible. From each a duct leads to its intereellular opening into the anterior end of the ventral furrow.

The ont let of the anterior pedal gland, the widened end of the pedal furrow, is of large size, and its walls are fashoued into numeroms folds (Plate 21, fig. 2) to afford sufficient surface for the exit of the many ductules. On the roof of the cavity two short longitudinal ridges, almost papilla-like, are present and from these numerous much smaller folds extend down the sides of the chamber to the extemal opening. After treatment with haematoxylin the secretion of the pedal ghand becomes almost black, indicating an alkaline reaction, while the cells lining the outlet of the podal gland (botween which the ductules make their exit) are bright pink in rolor and therefore distinctly ardid in their reaction. 
The wllk of the pusterior pedal ghand are of comparatively small size, but ofluerwise ane assentially the same as those of the anterion peral gland. As

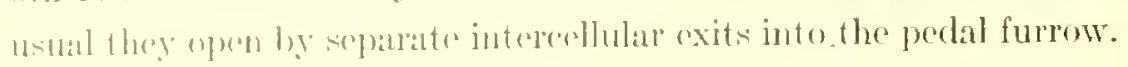

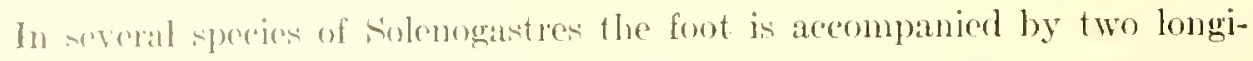
anlinal ridges, molilinations of the hypodermis. In the present species the median projection is lendered by two prominenees on each side. All are of (siscutialy the same size and appeatane, bring thin folds of epithelium into which a fow muscle and enmective-tissue fibres project. No blood spaces wectre within them and at their hases the secrotion from the pedal gland finds it: ontlot.

The atrial anvity in the only specimen examined is of limited extent (Plate 11, lig. 3). Int it possesses riclges of latge size that together with the eirrose area presents a very wasateristic appearance. The indistinet prominenee, which in some spercies arempanies the outer ridge, is not sharply defined, being reeognizallu woldy by the rod-like group of ganglion cells in the customary position. The muter atrial ridge proper is of large size, and as a much folded, horseshoeshaped clevation surrombls the atrial eavity exeept posteriorly. The inner foll is of infruior size and consists of two ridges which arise independently on the roef and posteriorly diminish in size and gradually disappear. Their epithelial avering consists of high slender cells with elongated subcentrally plaeed muclei distal to which the eytoplasm contains quantities of light yellow pigment. Intemally the folds are supported by strands of comnective tissue with a small arhixture of muscle libres among which well-defined blood simuses pursue their (")ullise.

The cirre arise singly from the atrial wall and are of more than ordinary

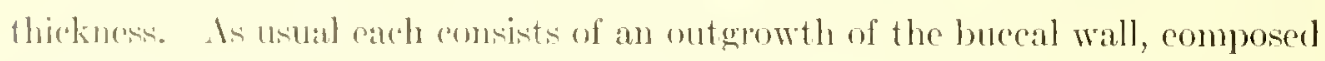
of more or less anbial oells in which the yollowish brown pigment is so abundant that it watly ameals the nucleus. The "avity of each cimus is very narrow, allowing the passage of al nerve strund but not of the blond.

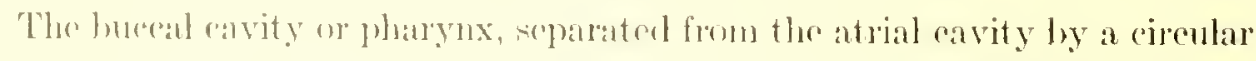
fold (l'late 11, lig, 3), is an irregulal eavity whose general appearanee and relations are reperented in Plate 21. The walls throughout are produced into mumeroms way more or less longitudinal fohk, lined with a thin cuticular sheet. In the millde thind, which eontains the ralula, the folds become more distinctly longitulinal, luat more justrionty they ance more beene very irregular.

As in . 1. agkswizi there are three sets of wallivary glands, and as may be seen in l'bate 21, tige. 2, 4, in arrangement and size, they are esicentially the same as 
in the foregoing species. The smallest dorsal glands (dsg) are more or less imbedded in the pharyngeal wall from the cirrose cavity to the posterior end of the radula sae. Each consists of an aggregation of well-marked pyriform rells usually charged with a finely granular darkly staining secretion. In some of the larger groups the secretory products are not so elearly granular and have a more reddist east, in this respect and in general appearance resembling the second type of dorsal salivary gland.

The second species of gland (sg) is in reality a paired strueture rach half consisting of about two dozen lobulate glandular bodies united by as many branches of a main duct which opens into the pharyngeal cavity. It appears probalble that each organ arose in the cmbryo as a diverticulum of the gut, and subsecpuently developed outgrowths in which some of the cells became glandular. These retaining their connection with the lumen of the duct elongated greatly, beeame pyriform and formed the lobule of the completed gland. As in A. agassizi the eanal in each lobule develops small lateral branehes and in any case the duct holds a superfiejal position.

The eourse of the main duet, which lies to the ontside of the glands is shown in Plate 21, fig. 2. It opens at the hase of a corrugated papilla enclosed in a diverticulum of the pharynx that in turn opens at the forwand border of a broad papilla on the pharyngeal wall (Plate 11, fig. 3). As in the foregoing species the papilla contains a few small canals which open on its surface, but their inner connections are diffieult to trace. They appear to be the outlets of a number of small glands belonging to the first type which, as noted above, approach the seeond in the form of the colls and the character of their secretion.

The tubules of the third set (gl) are in form and position like those of $A$. agassizi. The secretion is more abundant and more granular and darkly staining, giving them a denser, more compact appearanee, but this set is not voluminous as in the preceding speeies.

The radula is of the distichous type (Plate 11, fig. 3, Plate 34, fig. 14) and contains approximately thirty-four rows of teeth. These are developed by large mumbers of excedingly slender odontoblasts, and immediately after their formation are enveloped in sheaths composed of numerous so-called enamel cells. Both of these groups blend with eells that beeome smaller as the opening of the radula sac is approached.

At the forward border of the radula the cells of the pharyngeal wall become more columnar, less dense, and their nuelei assme a more slender shape. Appearances suggest a subradular sense organ, but it lacks the definiteness of this 


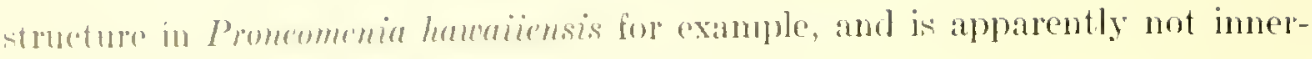

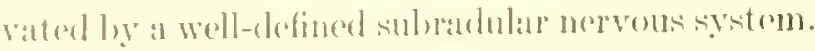

The orsophagus opers at the summit of a papilla (Plate 11, fig. 3) into the

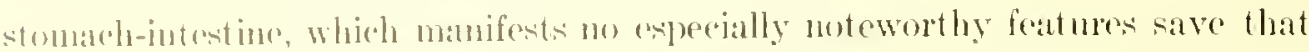
its lining is of steht thinkness that in preserved material it reduees the cavity to a narrow slit. In the posteror end of the body the gut narows to a vertieal

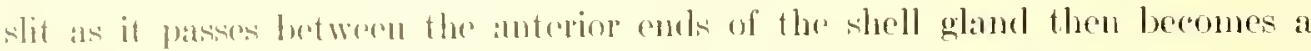
cinculall canal of mall size that opens into the cloacal cavity dorsal to the external repuremetive apening.

The rimenlatory system is aluost the axact combterpart of that in $A$. agassizi.

The reproduction system is likewise pratedially identieal with that of the foreguing speries. The periandial cavity is smaller, and the inner ends of the coelomoducts an more sender, but they rapidly inerease in size and their walls berome more than usually folded. The shell glame, especially its posterior half, is more distinctly lolulate and somewhat more ard in raction. The seminal

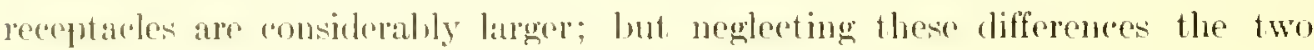
species agree closely so far as this system is eoncerned.

The hervons system is not esperially favorable for study and for this reason only the more obvious port inn have been examined. In all essential particulars these alosely resemble lomologons struetures in the foregring species.

Halomenia gravida, sp, nov.

This speries is represented by two indivinluals taken off Simushir Island uf the Kurile group at a depth of 229) fathoms (Nta. 4804). Both were diseovered in dead hamacle sholls and atre evidently fres roving forms. The larger speeimen is $11 \mathrm{~mm}$. long loy $1.0 \mathrm{~mm}$, arerage dianeter and the length index $7: 1$ is chatratereristic atso of the smaller one. The anterior cirrose section of the gut, or the at rium, is sepatrater from the succeeding portion by a rialge (Plate 5, fig. 3) "overed with the spriculose cutinde investing the body. Posteriorly the pedal growe is continuous with the cloatua which like the at rial opening, extends far up fowstrd the chersal surface of the body. The color is light yellow shacling to

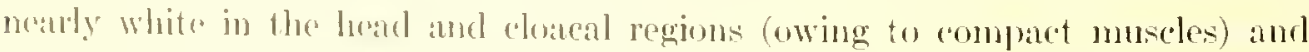
alomg the minl dorsal line where the gonad is situated. A dorwal sense organ is present (1Plate 22, fig. 12), and is renatrable for its larese size and from the fact that it is more anterionly loeater than is usually the aise with other speeies, being planed opposite the forwand cloaral wall. 
The cuticle, surrounding the body, is of average thickness (Plate 32, fig. 4), but is actually rather seant in anount owing to the large mmbers of spicules (Plate 22, fig. 13) imbedded in it and to the papillae many of which are of unusual size. On the rentral side of the body the ummodified hypodermal cells, those which are probably largely responsible for the development of the eutiele, are comparatively few in number and are erowded between the bases of the papillate. but dorsally they become more numerous and may be seen to possess a cubieal form and no especially noteworthy features. Owing possibly to differences in age the papillae vary greatly in size but all are constructed on essentially the same plan. As may be seen (Plate 32, fig. 4) the stalk is composed of an oulpusling of hypodermal cells and is mally shorter in the larger papillae. It is surmounted by the usual balloon-shaped group of (cells, which certainly muber not less than one hundred in the larger organs. Each coll is greatly elongated, vacuolated in its outer portion in preserved material, and contains a spindleshaped, basally placed muclous. In soveral eases the cavity of the stalk is traversed by a delicate fibre, sometimes cnclosing a nuclens, which appeats to be a nerve.

In this species the stomach-intestine is related in a remarkable way to the cuticle and papillae but for what purpose I camot say. On the dorsal surface of the smaller specimen and in the region traversed by the mid gut there are not less than twenty pairs of small romed knols of light yellow color, forming one lomgitudinal line on each side of the mid line. These are not distinctly visible in surface views of the larger individual, but in sections they are seen (Plate 22, fig. 1) to be eraginations of the clorsal wall of the intestine which protrude througl definite openings in the somatic musculature and extend half way to the miter surface of the body. Each is in eontact with the under surface of a circular dise-like pateh of hypodermal cells having the appearance of a modified papilla. The stalk is absent and the cells are relatively low, but some are distally racuolated and are not the compact, rubical elements of the mmodified hypodemis. Surrounding the point of attachment of gut and papilla is a small ring-shaped blood simus, frequently containing corpuscles. The relations of these various elements are represented in a typical condition in Plate 32, fig. 5. Coneerning their mode of operation it appears probable that the pressure of the blood in the sinus caukes a protrusion of the papillae and the attached liver lobe, but for what possible reason I cannot say.

The spicules, whose general shape is shown (Plate 22, fig. 13), are of various sizes in a mature condition even in the same locality. These are intermingled 
and lakk any very definite arrangenent further than that they encirele the (omprmons papillate, giving the animal as seen under fow magnification, a mottled appearances.

The anterior pedal gland oreupies the major portion of the space included betwen the gut (Plate 22, fig. 1), and bocly wall from the level of the brain to the stomalh-intestine. Its actls are comparatively small but the serpetion is abundant, andbling one to follow in many ases the slender ductule to its opening into the anterion end of the perlal furrom. The walk surrounding this extemal cutlet arre unfolded (l'bate 22, hig. 1), highly ciliated and form a cavity of more than usual siza. From its posterior border two ridges drelop (Plate 22, fig. 2) and extend along the pedal furrow to within a sbort distanee of the cloara, where they disulpleat though the furmw, reduced in size, becomes continuous with the charcal cavity.

In surfare view it is pussible to detert slight folds in the exposed cloacal wall which in sertions may be sern to become of much greater height within. These, twenty-six to thirty in number, at first hang freely in the cloacal chamber (Plate 22, lig. 11), but more anteriorly they brome attached to the wall of the rectum, and yet farther forward some of the clorsal ones extrud into the cavity above the rectum dividing if into a colresponding number of small crypts (Plate 22, fig. 8). In these last named spaces, and hetween the folds for some distance more posteriorly, upwards of twenty embryos have taken refuge and undergone the first stages of their development protected ly the parent. The epithelium of the basal half of each fold in contact with the embryo is low and seemingty non-ciliated, while that of the distal half assumes the high columnar, ciliated appearance characteristic of such organs in several ot her species.

As noted previonsly the cirrose section of the gut, or the atrium, opens subterminally and has no direc comection with the remainder of the digestive tract. Its cavity is largely obscured by the thick-walled, large ciliated ridges which hold the usual position and detine the cirrose area. The cirri are comparatively short and thick set and are usually united hy their bases in groups of two or fonl. Their cells are of the customary pigmented type and surround a lumen of exceedingly' small calibre.

Immediately belinet the opening into the atrium the cuticle surrounding the lody beromes continuous acrose the mid line for a short distance, and still more posteriorly loreaks through to form a second opening, probably the true montl. This aperture leack into an irregularly shaped avity (the general alrangement shown (Plate 6, fig. 3), whose walls, seemingly wiliated throughout, 
are developed into a complieated series of ridges. In the eustomary position a distichous radula is present and thomgh of small size is typical in all essential respects. It rests upon a delieate thongh perfeetly distinct basement membrane and is produed by odontoblasts at the bottom of a shallow sac. There are, so far as may be determined from cross sections, about twenty-four rows of teeth which present the appearance represented (Plate 34 , fig. 12).

On each side of the forward limits of the radula sae the narrow duets of the ventral salivary glands open into the digestive tract and on the other hand lead right and left into a reservoir extending far toward the dorsal side of the pharynx. Each of these cavities is surrounded by a gland (Plate 22, figs. 2, 5), componsed of multitudes of small, pyriform cells grouped, by means of delieate connectivetissue septa, into lobules of various sizes. The luctule from each cell makes its way to the wall of a reservoir into which it pours its granular, moderately staining seeretion by way of an intercellular opening.

Beyond the radula the alimentary canal courses dorsally and opens into the stomach-intestine. In front of this junction a eoecunb extends far forward and as noted previously develops on each side of the mid line diverticula which pierce the body wall and cone in eontact with the under side of what appear to be modified papillac. These are developed also by the stomach-intestine throughout its entire extent. A further peculiarity of the mid gut exists in the form of numerous small secondary outpouthings of the wall of the ordinary gut pouches which give in cross section a complicated appearance to this region (Plate 22, fig. 3). The dorsal wall of the intestine, in contact with the gonad, is relatively low and hearily ciliated. At the level of the forwarl perieardial wath the gut narrows rapidly, loses its glanchular character, becomes ciliated and by a relatively small pore opens into the cloaca.

The position of the heart, its relation posteriorly to the branchial folds and anteriorly to the aorta are typical. As is seen (Plate 3 , lig. 5) it consists of two divisions united by a small canal apparently provided with a valve. Both portions are moderately numeular, and lorke in the meshes of the muscle bands numerous large, irregular cells which have the appearance of blood forming elenents. The aorta, extending anteriorly and dorsal to the gonad, supplies the last named organ with many well-defined ventral branches whirh, as in $P$. hawaizensis, pass ventrally along the mid line and reaching the neighborhood of the gut course outwardly and then dorsally to unite with the larger spaces beside the aorta. In the head region this main vessel communicates as usual with sinuses which earry the blood in turn to spaces between the gut and body 
wall. Oppesite the anterion end of the thell wand the ventral simus enlarges,

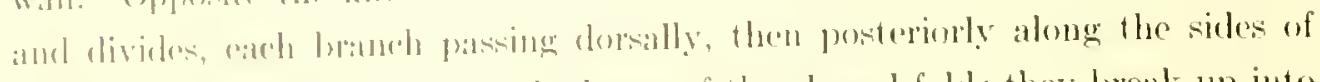

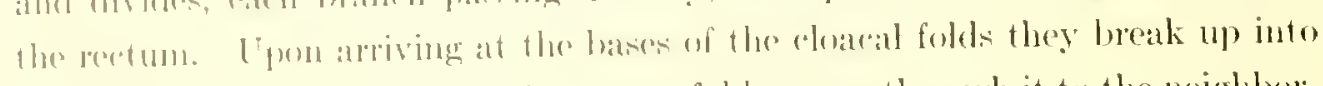

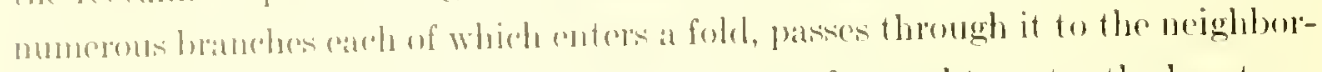
horel of the bedy wall wherengen it nakes its way forwand to enter the heart.

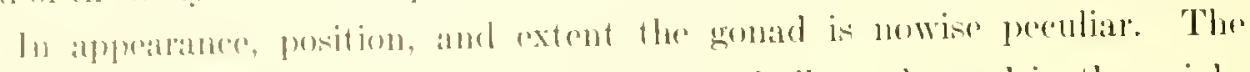
reprometive olements in the anterior third are wholly male, and in the neigh-

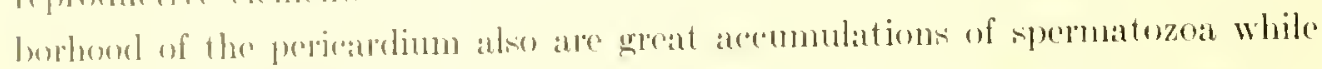
in an intermeeliate position the great ova, $0.26 \mathrm{~mm}$. in cliameter, are most eonspicuons objects. Correlated with their great size the eluets leading into the

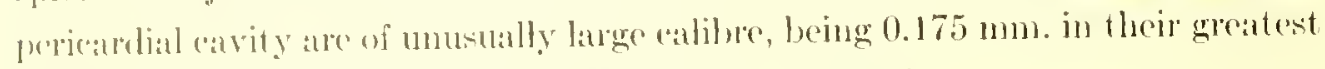
diameter. The thinge ents ane low and heavily eiliated.

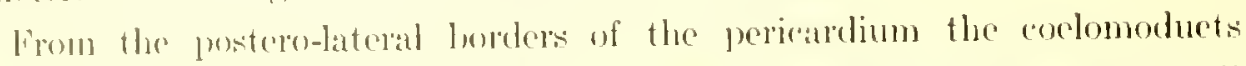
arise, extend outwarl and forward and enlarging somewhat mite with the shell gland (Plate 3, fig. 5). In the carly part of their contse the cells, like those lining the pericadiuns, are low, but more ontwardy they become nore eohmman and form longitudinal ridges of considerable height. At the anterior limits of the shell gland is the opening of the sominal reeptacle, which is a simple unbranched tube, cmpty in the mesent instance, and is provided with a high ridge extending, like a typhlosole, throughout its length. "The cells composing this batter organ are slender, triangular clements which when combined form a fan-shaped structure in cross section. A heavy layer of cireular muscles enshoths the seminal receptacle, and a few ladiating bands extend from it elaiefly to the body wall.

As lisual the sholl whand is I-shaped and in the merent example is fully functional. In the nejghlorhoud of the sominal receptacle its cells are rather low and their secertions small in anmout, but half way down towat the mid line they hoome greatly olongated, and distally contain a linely gramular sectetion which oseapes in latege efuntities into the humen of the duct. Tpon the fusion of these tulles in the mid line the dorsal wall of the undivided section is composed of eells, also bigh in form, which dumg the carty stages of glandular aletivity are fillect with a darkty staining vacuolated secretion (Plate 15, fig. S and Plate 22, lig. (i). This eondition of alfairs, mucous celts dorsal and abumen forming alenents lentow, continues to the single median opening in the cloacal eavity.

As noted previomsly this spereies broods its young. The eggs, about two dozen in number, have been reteined in suares between the great branehial folds in the coloan wall and evidently they have conne down at different periods 
as all stages of derelopment are represented from a 4 -ecll condition to advanced larvac where the shell and foot are indieated, the fore and mid gut elearly differentiated, the anterior pedal gland developed and to some extent functional, the central nervous system partly outlined (Plate 22, fig. 7). I fuller aceount of the embryology is planned for a later paper.

The brain, of usual size, holds the customary position above the pharynx. The anterior nerves passing to the cirri, ete., and the pedal, lateral, and buecal connectives have the usual relations. Anteriorly the pedal cords enlarge and are united by a more than usully heary commisure, and each gives rise to a nerve that passes to the wall of the outlet of the anterior pedal gland. Here and there pedal commissures may be dotected, as woll as connectives with the lateral cords, but these are usually small and often very difficult to follow.

The labio-buecal connectives are imbeded in the walls of the pharynx and connect with ganglia, of rather small size, located at the sides of the radula. These ganglia are united ly a commisture ventral to the pharyux posterior to the radula. The ganglia, and more anteriorly the connectives, give rise to small fibres that may form commissures, as in other species, but their lack of sharpness renders it impossible to trace them more than a short distance into the pharygeal wall.

In the posterior end of the body the pedal nerwes diminish in calibre and disappear beneath the shell gland. The lateral neres, upon reaching the forward border of the shell gland, pass diagonally inward toward the mid line until they reach the level of the outlets from the pericardiun. Here they anlarge (Plate 3, fig. 5) and are united ly a commissure passing dorsal to the rectum. The last two connectives between the pedal and lateral cords are of about twice the usual diameter and pass to the imer side of the shell gland. From the posterior superior ganglion several nerves arise that course over the eloacal passage to which they give off delicate fibres, then extend into the somatic musculature and probably are distributed in part to the hypodermis. Near the mid dorsal line two other nerves originate and attached to the forward wall of the cloaca pass dorsally and are distributed through the somatic musculature in close proximity to the hypodemis.

Herpomenia platypoda, sp. nov.

Eleven specimens of this species were taken in the neighborhood of Igattu Island of the Alcutian chain (Sta. 4781) in water 482 fath. in depth. All were attached (Plate 1, fig. 4) to a colony of some unidentified campanularian hydroid 
and raried in stze from $11 \mathrm{~mm}$. in length and $0.6 \mathrm{~mm}$. diameter to $18 \mathrm{~mm}$. long and ().) mm. in thickness. I well-defined dorsal keel extends throughout the antive length of the animal with the exception of the extrene postorior and. In a contratedel state both ends are pointed and quite similar, hut usually the atrial atrity is opened so that the outer ridges are cxposed, thus griving the front end a blunt apluarance. The color is white or ycllowish white,

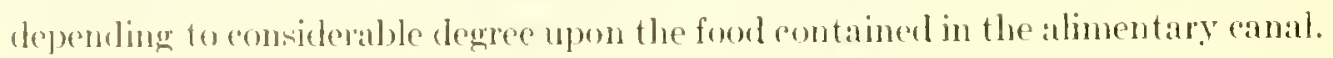
1 single layer of spieules anvelops the body, the majority being leaf-like in form and bienvex in crose section. A recond type with a short stem occurs in the neighlorhoud of the ventral furrow, and to a less extent over the body generally. The cuticle is more highly developed than is usual with speeies in this family, and is underlaid by a hypotermal layer of more than usual height beneath the dorsal kecl. In their general appearance the component cells resemble those of some of the Chatodermatidae, being of cubieal or rectangular shape, or in the case of what appear to be spicule matrix cells more or less globular except in the region of the keel where they are much elongated.

The anterior pedal glant (Plate 19) ocempies practically all of the head region not held by the rentral salivary glands from slightly in front of the middle of the pharynx to the forward end of the body. The erypt into which it opens is typicalty placed (Plate 8, tig. 1), prssesses mofolded walls and is profusely ciliated. Posteriorly the anterior gland joins, without any sharp line of demancation, the posterior one which eontinues to the cloaca.

In the anterior end of the body the foot is the merest fold or it may be entirely smoothed out. 'This latter condition obtains in the posterior half of the hody (Plate 19, fig. 10). However, all of the colls retain their ciliated eondition though they are more colummar than the ordinary perlat cells of other species.

The atrial calvity is unusully small (Plate 8, fig. 1) and the outer ridges are lacking or are without dearly defined boundaries. The inner elevation on the other hand is a prominent fold, penctrated by blood simuses, and is composed of cubieal cells save along the free border where they are higher, more spongy and heavily ciliated. The cirri, presenting the customary appearance, are arranged in groups of $3-7$. The opening from the atrim into the buceal-pharyngeal section is comparatively narrow, being reduced by a large fold springing "hiefly from the domat side of the digestive traet. Beyond this the canal widens, its lining epithelium becomes considerably folded, and is composed of columnar rells endowed with considerable glandular activity. Still farther inward the wall again develops a circulitr fold which forms the outer boundary of another circu- 
lar groove between it and the muscular pharynx. Through the posterior wall of this groove the ventral salivary glands lind their ontlet by means of two duets very closely situated to the mid line (Plate 8, fig. 1, Plate 19, lig. 8).

The vent ral salivary glands are unusually large organs emmpletely encireling the gut for part of their course, and oceupying most of the space between it and the body wall from their outlet to the junction of the pharynx and stomachintestine. The edls composing them are pyriform, $0.024 \mathrm{~mm}$. in greatest diameter and are filled with a homogeneons, moderately staining secretion in which the relatively large molcus holds a more or less central position. The colls are arranged in lobules, and their delisate ductules open by intercelular channek (Plate 19, fig. 13) on each side of the body into a reservoir whose superfieial extent is much increased by several folds. The outlet from ead reservoir pasters to at small divertientum of the pharyngeal wall into which it opens opposite its fellow and very close to the median plane.

The pharyux is a prodigiously heavy tuhe whose walls are composed of a compact mass of muscle fibres chiefly circular (Plate 19, fig. 7) lined with high eolumnar cells developed into upwards of a dozen longitudinal folds. These last named elements contain a weakly staining secretion and are in contact distally with a distinct cuticular membrane. Posteriorly this tube projects some distance into the stomach-intestine, Plate 8, fig. 1. A radula is completely lacking in this species, and it is probable that, as in Drepenomenin rampyrella, the secretion of the salivary glands exereises a solvent action on the tissues of the host that are then sucked up by the pow orful pharynx though its exact mode of operation is dilficult to muderstand. Nettle cells, from the host, are present in the intestine, in some cases seemingly imbedded in the epithelial rells.

The lining of the stomaeh-intestine, where the distal portions of the eells bearing the secretion have not been detached, is excessively high, in one specimen almost oechuding the lumen. Beneath the gonad is a snall median fold apparently eiliated, and showing evidence of slight ghandular activity. I'entral to the pericardial eavity the gut rapidly narrows to an ahmost cireular tube of snatl calibre and opens with the shell gland into the cloaca.

The pericardial cavity, as may be seen (Plate 8 , fig. 3), is of moderate size only, and is in large measure filled by the simple tubular heart. The anrta in exceptionally small as are the sinuses generally with which it conncets, yet so far as they have been traced their relations appear to be perfectly nomal.

The gonad holds the customary position, but is remarkable in sereral respects. In the first place it is sharply differentiated into two zones in the two 


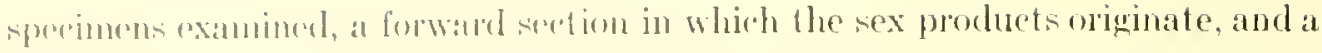

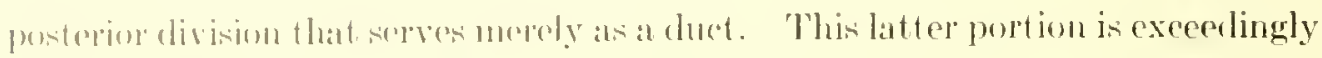
natrow (1'late 8, lig. 3), upwards of twire the bodily diameter in length, is with-

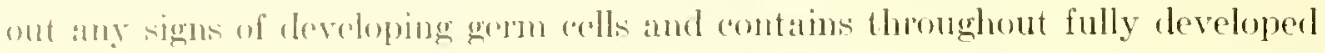

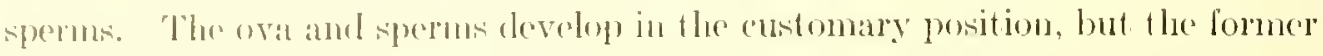
are scaut in amount and momsually large, ahost completely filling the gland.

lisperially about the periphery aroh ovum contans imbeded in the yolk latre mumbers of alear vesicular bodies (Plate 35, fig. 9), approximately 0.0068 mmo. in diamoter with an eecentribally placed darkly staining mass usually superficially placed. At lirst there bondies appeared to be remnants of nutritive cells, posilny modified follicle cellin, but subsequent study leads strongly to the conviction that they are portions of fragmented muclei. In the early stages of ova devolopment these same bodies occur, but are of extremely mall size (Plate $\mathbf{3 5}$, fig. 6). Atill earlier (Plate 35, fig. 7) it has been possible in several cases to find imberded in very small ova from one to three colls resenthling primordial gem cells, and probably corresponding to follicle cells that are known to oceur in a fow Solomogastres. These nuelei in a slightly older stage berome somewhat larger and stam blue instead of light red or pink. 'The gramules assume the resiecular appearance ehaturteristic of later stages and slightly later upon the rupture of the nuelear membrane become seattered throughout the egg. Against the belief that these structures are cells may be urged the fact that in their anly derelopment they are much smallel than any cell of the body, measuring not more than $0.000 \mathrm{smm}$. in diameter, and secondly there is at no time any sign of a cytoplasmin mass. These gramules correspond elosely in size and number to the

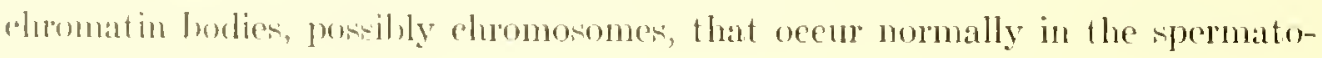
rytes.

In the peridadial carity the spermatozoa are attached in considerable numbers to the wall especially along the dorsal surface, or at the time of the animal's calpture were leoing swept along in a curent passing beneath the heart and ontward through the coctomoducts arising from the posterior wall. The dorwal section of rach duet (Plate 8, lig. 3) is a simple tube of even calibue throughont, pasing downwad and formal from the perieardiun to unite with the shell gland. Shortly bofore this union it mites with the duct of the seminal receptace, wheh resembles a llask with a long eurved neck. This last named organ like the dorial limb of the coelomoduet is lined with cubieal cells possibly riliated, to which are attached a small number of spermatozoa.

The whell gland is a globular body and almost totally lacks the cornua 
prominent in the majority of species. On the sides of the organ the epithelinm is comparatively thin but it rapidly becomes thicker atbove and below owing to the excesive development of ntmemens gland cells. In this highly developed condition each cell is a goblet-shaped body with very slender stem and a slightly expanded base in which the nucleus is placed. The seeretion consists of a granular mass much like yolk in appearance and staining reaction. Among these larger elements slender supporting cells, usually with subeentrally placed spindle-shaped nuclei, oceur in considerable numbers. Both of these clements occur on the sides of the organ but as mentioned previously they are very low and eubieal or rectangular. Sinee the distal portions of these cells are dislodged in the apparently nomal process of liberating the secretion it is probalule that at times these lining cells are of greater height. At the postero-ventral surface of the gland a short narrow duct, whose position and general appearance are represented (Plate 8, fig. 3), makes its way into the cloaca.

Owing to the similarity of the nerves and conneetive tissue, and muscle fibres, and the consequent difficulty of tracing these to any extent, the nervons system has not been examined.

Dondersia californica, sp. nux.

One immature speeinen taken at a depth of twenty-one fathoms off southem California (sta. 4303) is the sole representative of this speries. Owing to the fact that it bore a superficial resemblance to several small nenerteans it was killed with them in corrosive acetic destroying totally all traces of ealearoous structures.

The general form of the body is shown (Plate 3, fig. 9). The length is $7 \mathrm{~mm}$. and the greatest diameter $1.2 \mathrm{~mm}$. The pedal grove, and single, included fold, is continuous with the cloaca though at the point of union the former has become very indistinct. The outlet of the anterior pedal gland is a well-marked invagination with highly folded, ciliated walls. In this gemus more than one dorso-terminal sense organ is present, two being found in D. festim and three in D. annulata aceording to Nierstrasz (02). In the present species eleven exist, all construeted on the same plan (Plate 35, fig. 12). Of these five ocmur along the mid line, and the others are not far removed from it. Is Plite 6 , fig. 2, shows they are not symmetrically disposed for of the six not in the mid line five are on the left side of the body. Each organ consists of a globular mans of slender cells, with elongated mesially placed nuclei, eovered distally with a thin continuation of the cuticle investing the body. From the bases of the cells 


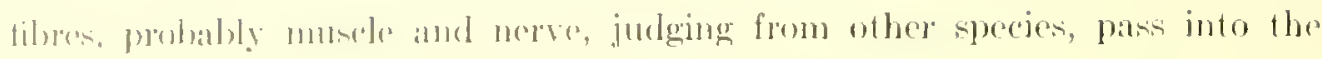
momlerlying tisisur.

It is revilent from the thimness of the enticle (Plate 32 , fig. S) that but a single bayer of spicules exists in this species and from spaces in the decaleilied

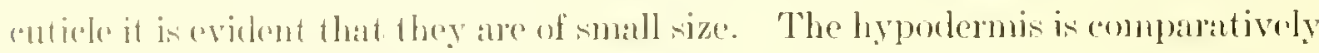

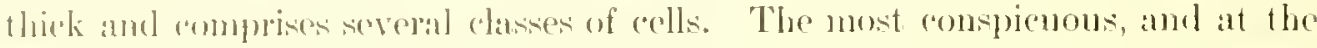
simk time the most rare, are gland aells which are generally more deeply planed than the ofluore olements between which their dolicate duetules pass to the exterion. These ane most abumdant on the ventral surface.

It all points there are almomd-shaped spaces in the hypodermis which antear to have been tilled with a calcureous product, and judging from the eell remant watly in commertion with them, it is probable that they are spicules in process of formation. The cells apparently respomsible for the formation of the cuticle are columnar, non-staining elements containing a centally placed nuclens. Between thom are very slenter colls with spindle-shaped mesially placed muled whide may possess a sensory function though this is not definitely established. No papillae are present.

In this species the atrial cavity, porided with cirri and ridges, is entirely elistinet from the radula-bearing region which communicates with the exterior by an opening immediately in front of the outlet of the anterion peclal ghand (Plate 5, fig. 4). In this forward elivision the dorsal or imermost of the bue al riclges is ladking; the external one on the other hand is prominent and abundantly ciliatcol. The cirri are united by their bases into groups of three or four or ramely six. In this anlurged basal part it is sometimes possible to distinguish a fow hijolar colls whill comect with filnes passing distally through the cavity of cach cirrus, and in a reverse direction hecome lost to riew in the vicinity of

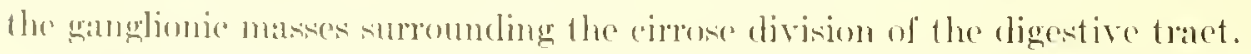

As just moted this anterion ond of the alimentary canal is separated from the

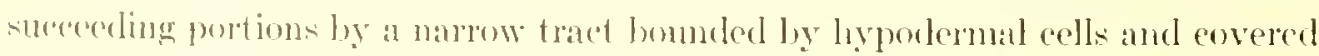
with a spiculese muticle. Whether this division line disappears later in life, the rirowe section then communicating with the remander of the gut, as is usually

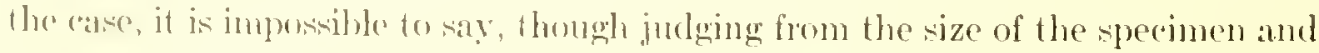

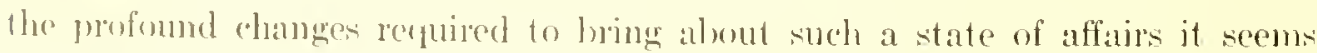
probathle that the present arrangenent obtains in the sexually mature individual. Fom the foregoing it develops that what Thiele assumes to be the true mouth is an independont apening communeating in the present instance with a comparatively marow plicated tube leaching into the larger pharyngeal, radula- 
bearing portion which in turn comects with the stomach-intestine by a short ocsophagus.

Dorsal salivary glands are represented by a small number of pyiform cells communcating with the pharyx immediately behind the level of the bran. Slightly more posteriorly there are other similas colls, but they cammot with certainty be differentiated from the anterior pedal gland. The ducts of the ventral salivary glands open elose to the mid line on each side of the forward end of the radula (Plate 23, fig. 5). Distally they make their way, as stendel. tubes, in a lateral direction and then expanding to twice their initial diameter proceed for a short distance posteriorly. To this expanded portion are comnected multitudes of pyriform gland cells arranged somewhat indefinitely into bobules attached to the lateral and ventral walls of the pharynx. In D. ammlata Nierstrasz (102) finds mmerous cells situated about the rentral ducts; it is probahbo that they are the salivary cells whose ductules have been destroyed owing to faulty fixation.

The radula is comparatively small and the teeth rery transarent so that it is somewhat diffeult to discover their exact form. Judging from cross sections each tootl consists first of a basal plate (Plate 8, fig. 8), narrow rectangular in form, and withont any commection with the plates of neighboring teeth. This basal bar supports what appears to he a triangular median tooth, but high powers resolve this into a pair of elements closely appressed. It thus appears that the radula is monoserial, each bar bearing a pair of conical cusps. On the other hand the radula may be considered biverial, the basal bar representing a basement membrane, but against this is the fact that the bars are not united with each other. There are not less than twolve teeth if the radula be considered monoserial.

Beyond the radula the digestive canal narrows, becomes folded longitudinally and opens abruptly into the stomach-intestine that after forming a short dorsal and ventral coecum develops the deep, characteristic lateral pouches with glandular walls. In the mid dorsal line the epithelium is differentiated into at fold composed of high, richly ciliated cells which laterally become reduced in height and gradually shade into the non-ciliated digestive cells. The relations of the gut to the cloacal cavity are indicated (Plate 6, fig. 2).

The perieardium is spacious and the heart is of more than average size. The blood from the posterior regions of the body pours inte its posterior division corresponding to an auricle (Plate 6, fig. 2), thence into a ventricle-like portion and from there is driven into the aorta. This ressel throughout its entire extent 


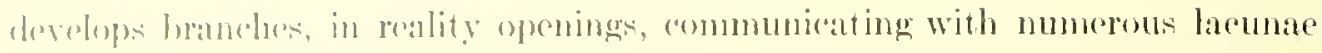
in the dorsal crest-like portion of the buly. Thene in turn comnect with others of lest extent in the linteral regions and through these with the pedal sinus. In

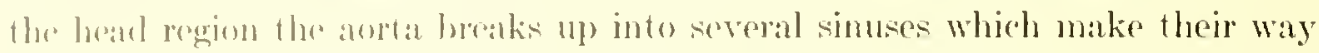
through the anterion perblal gland to conneet with the pedal sinus and the more lateral spates just described. In the posterior coul of the animal the blood

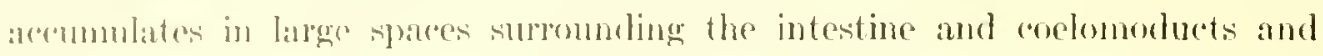
pours into the heart loy meatse of a sims passing dorsally on each side in the meighborluod of the reno-perieadial openings. The pedal sinus continues

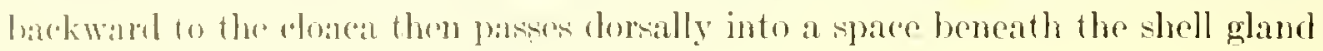
and from there into vesiols leading 10 the heart.

The enond is distinetly pared, the a wo divisions being in contact only in the minklle of the body. Elowhere they are willely separated by means of the dorsal alorta. In the mid section spermatogonia are fairly numerous and at all points orat are commencing to develop. In the heart region the glands narrow and communimte with the procardimm, which posteriorly communieates also with the conomoducts opening into the cloaca. The dersal division of these tubes is compantitively slendere and is composed of cubieal ciliated colls without signs of undulat activity. No trace of a seminal receptacle is visible unless what appears to be the anterior end of the ventral section may be so considered. This lower division, or shell gland, is composed of rather low colummar cells, tomling 10 form longitulinal ridges, but they likewise are inaetive.

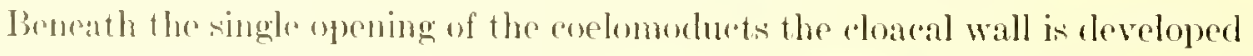
into an ontpounhere which in the adult animal may develop copulatory spicula (1) some gland commected with the egg-laying process, though in the present sperinem such functions are purely lypouluetions. In shape this outgrowth rescmbles a thick set $\mathbf{Y}$, having a median umbivided section which opens into

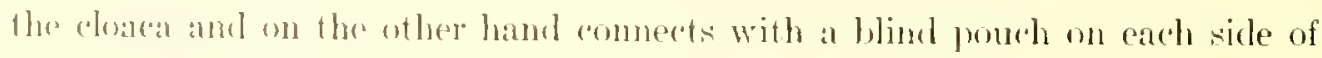
the minl line. 'The walls are not unlike thowe of the shell gland, consisting of colummall" colls which are lichly ciliated.

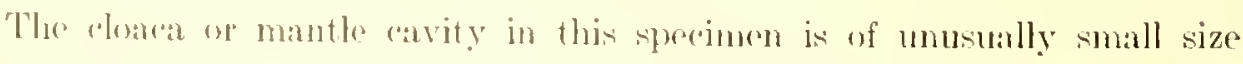
though it may increase in diameter as the mature condition is approached. A

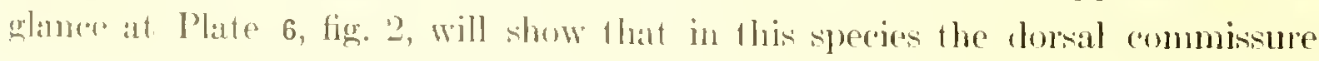
nniting the lateral nerve cords is placed uneommonly mar the coacal opening. If in the alult the eommissure is customarily placed it might readily be

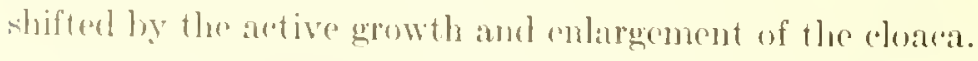

The nervons system is typiral. The lowin is situated posterior to the atral 
eavity, or cirrose portion of the digestive tract, but with reference to the pharynx it is normally situated. As usual branches pass out from the anterior surface of the brain to unite with ganglionic masses about the bases of the cirri which they appear to innervate and three pairs of commectives unite with the labiobuceal, pedal, and lateral nervous systems. Connectives and rommissures, agreeing elosely in number with the gut pouches, join the pedal and lateral eords throughout the body. In the region of the cloaca the pedal cords diminish in size and fundly disappear, and the hateral cords likewise diminish eonsideably in ealibre, and are mited by a commissure which unlike the usual type, is devoid of ganglion cells.

The labio-buecal connectives, imbedded in the pharyngeal wall, attarh to large ganglia lateral to the salivary ducts. Owing to the numbers of salivary ductules it is very difficult to trace nerves in this region and determine if there be more than the one commissure uniting these ganglia beneath the pharyox.

\section{Ichthyomenia porosa, sp. nov.}

Upwards of twenty individuals of this speeies were taken in one lrealge haul (Sta. 4400) off the coast of southern California, and two additional specimens were captured in the same loeality at Station 4402. In both cases the bottom consisted of green mud at a depth of 500-507 and $5+2$ fathoms respectively. All were unattached and there is no evidence whatever regarding their mode of life though it is possible that they may he parasitie upon some of the sea pens (Pennatulidae), of which three species abound in this locality.

There are slight inequalities in size due to differences in age and sexmal maturity but the average length is approximately $16 \mathrm{~mm}$. with a diameter of $1.2 \mathrm{~mm}$. The head region is indistinet (Plate 3, fig. 4) and externally is characterized merely by a very slightly greater diameter than that of the boty. Posteriorly, in an uncontracted state, the body terminates in a pointed extremity, but in other cases it may become blunt and where the cloaca is opened widely, trumpet-shaped. A pedal groove is present and as usual extends from the hinder border of the mouth to the cloacal opening with which it is continuous. The opening of the anterior pedal gland is usually very distinct, having the appearance shown in Plate 5, fig. 6.

Of the spines covering the body by far the most abundant are exceedingly delicate, of a pointed ovate shape (Plate 37, fig. 1), $0.024 \mathrm{~mm}$. long, and are

imbrieated, forming a single layer. In the neighborhood of the ventral furrow these are associated with a somewhat similar type, $0.0594 \mathrm{~mm}$. long, with 


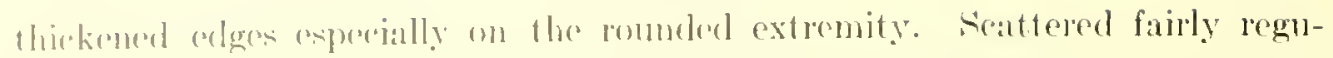
lanly among the lirst vitricty are those of the second type, paddle shaped, with short handle and a length of $0.054 \mathrm{~mm}$. Along the ventral furrow they are of a greater lougth, $0.01 \mathrm{~mm}$.

The hypolemis is apparenty one coll thiek but the species is peculiar in baving the labor dovelopod into many transverse foldk (Plate 32, fig. 7 ) especially on the dorsal surfines, and in seetion these ridge-like elevations renter the eell mations absure. These wrinkles are more pronounced in some specinens than in others, and are usually more prominent in the anterior half of the body. In - mone cases they are doulytless due to reagents but usually they are certainly momal. The omlinary type of hypulermal coll is rery slender, especially in the ridges and is provided with a relatively dense subeentrally placed nuclens. Aecompanying these are mumerous larger, more globular cells, apparently in latrge measure empty in preserved material. This may be due to the precipitafion of ame highly watery secretion, or more probably to the decalcification of some calcareous product.

This species possesses upwards of fifty remarkable organs, apparently sonsong, located ahefly abunt the anterior end of the boxly in front of the outlet of the anterion perlal gland. All are situated in the ventral half of the animal. Fath eomsists of an invigination of the hypodermis (Plate 24, fig. 12) with an arorage depth of $0.1 \mathrm{~mm}$. The lining cells aro low, very indistinct and are porided with what appor to he very long cilia, which in most ases extend slightly beyond the general body surface. In the most farorable specimens delieate fildes attach to some of the ecels but on the other hand they have never beent trated to any muloubted nerve. It is impossible to determine their function yet it may he that in life they act as tactile organs like the apieal tuft in the trochopplowe larria.

The anterior prelal gland is comparatively large (Plate 24, fig. 1) and ocen-

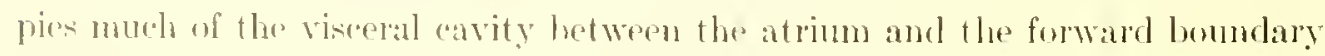
of the stomarli-intestine. Its cells are arranged in large gromps and are filled with a miformly granular, lightly staining secretion that after its escape appears ats a visunk, darkly staninge substance. The posterior pedal gland consists of colls lilled with a darkly staining, fincly granular seceretion clearly distinguished from that of the loregoing group. Interionly it rests against, and opens through, the posterion wall of the outlet of the anterior pedal gland, and more posteriorly forms a thin sheot resting against the ventral body wall and opening between livo folds in the sentral furrow. losteriorly these folds very soon disappear sive mo, the foot, and the acempanying glands diminish greatly. 
The atrial opening is subterminal and opeus into a comparatively large sized cavity (Plate 5, fig. (i) in which the ridges (Mundleisten) appear to have no existence. On the other hand cirri are present in great abundance and in some specimens project from the mouth for a short distance. These organs may spring directly from the buceal wall, but especially on the sides of the mouth they are borne in groups of from three to seven on stalks containing muscle and connective-tissue fibres between which there are extensive blood sinuses, enabling the animal to project the cirri through the mouth opening. Each eirus is an umbranched process consisting of small cells with very indistinct nuclei and eell boundaries owing to the large amount of yellowish brown pigment. In all of the specimens sectioned numerous pigment gramles have eseaped from the cirri and at various places form small acemulations, but whether this is a normal proeess it is impossible to say. This secretion renders it also impossible to determine their innervation, a difficulty that is increased by the small ealibre of the contained canal which in preserved specimens is too narrow to pormit the entry of blood corpuseles.

The cirrus-bearing section of the digestive tract passes abruptly into the succeeding region, the junetion in every case being guarded by a distinct fold which thus appears to be a permanent structure. At first the buceal-pharyngeal walls are almost smooth and the epithelial lining, composed of cubical cells, is thin but opposite the mid section of the brain the lumen narrows, becoming trefoil shaped in section, and numerous small transwerse folds have developed which now are of greater thickness. This condition of affairs continues with slight modifications to the region of the ventral sulivary glands where the canal becomes increasingly narrower and the corrugations more pronounced. As Plate 5, fig. 6, shows a clearly defined fold is present at the junction of the pharynx and stomach.

Throughout its entire extent the walls of the pharynx are thick and are composed internally of heary circular museles to which are attached numerous radiating bands inserted on the other hand to the body wall. All signs of a radula are absent and appearanees suggest that this species like Drepanomenia rampyrella subsists on some delicate organisnl, such as the seat pens, whose juices are extraeted by powerful sueking movements of the pharyx.

Two ventral salivary glands are present in the form of small tubular outgrowths opening on the underside of the pharynx about opposite the level of the hinder border of the brain. The cells are small but are filled with an abundant secretion, indieating that though these organs are dimimutive they are functionally active. 
1. indicatod (Plato 5, fig. (i), a dorsal enecum is but slightly developed, and the intestime from its junetion with the pharymx to the woaca is of uniform size

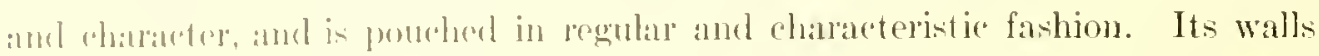

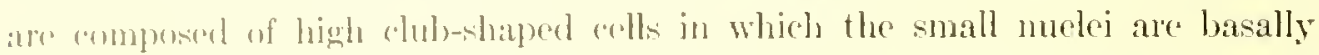
situated while the remaining portions are filled with lasge droplets of some

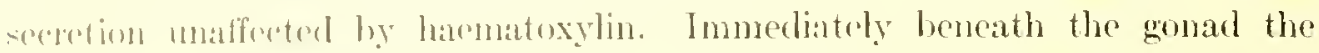

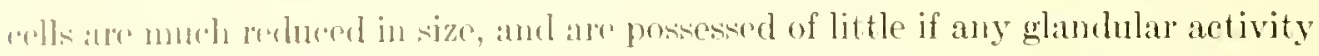
lut bear a heary wat of rilia. Neat the anterior enel of the coelomoducts the digestive callat nallows al)ruptly (Plate 6, fig. 1) to form a small canal which arising near the vontral side of the animal makes its way dorsally on the under side of the pericardium (Plate 24, fig. 5) to open inte the cloaca. The cells compuning it an essentially the same as those lining the intestine beneath the gemat.

The hemmprodite gland extends forward as far as the posterior limits of the phatryx ur slightly beyond (Plate 24, fig. 4) and in a sexually mature animal contains ripesex products throughout its entire extent. These originate in the usual fashion and are in no wise peculiar save that the fully developed roge are unusubly lauge, measuring $0.176 \mathrm{~mm}$. Clearly defued tubes lead from the gontel into the perieardium, which in the specinen represented in Plate 6, fig. 1, contins both ova and sperms. The antero-ventral perieardial wall is ciliated and alsewhere cilia appear to be present though the true condition of affairs is makked by the abundance of precipitated secretion.

From the posterior end of the prericaldim the coetomoducts arise as relatively narrow camals lined with alnost enbical cells bearing a coat of cilia similar to these of the pericardiun. Conrsing downward and forward they gratually increase in size and the walls, retaining their ciliated coat, elevelop sereral folds before they unite with the limbs of the buge gland a short distanee behiud their anterion loumblatios. It about one fourth of the distance from the perieardial ofrening to its outlet into the shell gland each tube originates what probably functions as a seminal vesiele (Plate 6, fig. I). In calibre and histological features ande is sincilar to the lleighboring parent canal with the exeeption of the distal oxtrentity whish forms an cularged, almost globula diation. From lerginning to ond the exicule seminales contain spermatozoa in most cases

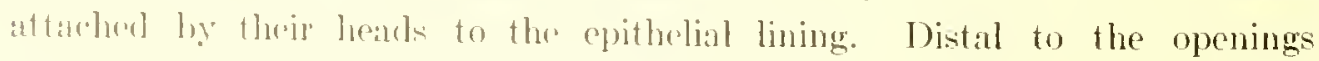

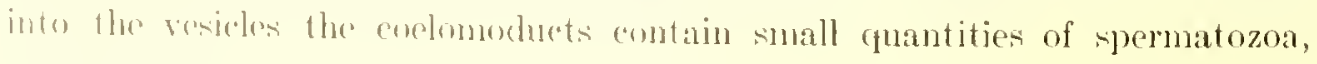
minttiacherl.

Nothe junction of the chorsal and ventral limbs of the eoelomoduet on each 
side a very large seminal receptacle is attached. Each originates as a slender duct, which pursues a tortuous course anteriorly, and opens on the lateral or latero-ventral surface of a vesicular eulargement with folded walls. The cells eomposing the duct are histologieally essentiatly the same as those of the seminal vesicles save that they are of ahnost twice the height. Those of the dilation are likewise columnar and contain a glandular secretion which escapes distally in the form of moderately staining droplets. In addition to this secretion the receptacle eontains numbers of sperms some of which are deeply imbedded in the walls. Whether these last named struetures are intact or not it is innpossible to state; they show no alear signs of disintegration.

The Y-shaped ventral section, or shell gland, is of large size and its walls, developed into many irregular folds, are unusually thin. Distal to the median, undivided section the cells of the epithelial lining are ahiefly glandular, hemmed in by slender supporting cells, and are filled with a violet colored varuolated secretion in haematoxylin preparations. In the adjacent undivided region this type of eell is replaced by another of much greater length: (Plate 24, fig. 2) in which the secretion is more vacuolated and stains less deeply. Associated with these are eomparatively few elongated cells filled with a dark, coarsely granular secretion and very many containing in each a granule of a dark brownish color. These oceur in the anterior half of the undivided part of the shell gland; from it the transition to the posterior half is very abrupt, especially dorsally where the cells beeome higher and are filled alnost eompletely with a substance of varying eharaeter, depending probably on the nearness of the egg-laying seaton. In one specimen with sex products in the perieardial cavity these cells near their free surface contain one or two large spherical dark blue or violet globules, while the remaining eytoplasm, is packed with an almost homogeneous mass. Ventrally the secretion is more gramular and the more distal products are yellowish brown in color. In another speeimen treated in identically the same namer these products have much the same appearance, lut stain slightly. The lumen of the shell gland is spacious and opens in the dorsal part of the cloacal ravity near the anus.

Opening by a wide pore posterior to the reproductive out let is a large divertieulum of unknown function (Plate 6, lig. 1). Its walls are somewhat folded and are reinforced by a thick muscular coat (l'ate 24, fig. 2). The epithelial lining consists of columnar eells of average height eovered externally with a thin, sharply defined cuticular layer. Among the eells of this character are others, fairly numerous, very slender, with dense elongate nuelei, that in especially 
faverable matrial may be serm to terminate proximally in fibres passing into the musche layer. Distally they attant to the bottom of minute depressions in the anticle and therefore probaldy are sensory elements.

In two sporimens the elonted witrity has been widened greatly, completely axposing the anme and the apenings of the shell gland and the more ventral divertichlum. 'This last named organ has been almost completely everted. There individuals alpueare in all respects to be nomal.

IVith the stains cmployed the nervous system is not shapply differentiated from the suromuling tiscue, and acondingly but bitle has been determined save that relating to the larger ganglia and nerves. As may be seen (Plate 5, lim. (6), the lowin holds the usual position and gives rise to the customary nerves (listributed to the atrium and the body wall and more posteriorly to the pedal, latcrat, amd labiu-burcal connectives. The pedal cords are eonsiderably enlarged at their anterior cuds, while the lateral show searcely any modifieation. Pedal "ommissures and later()-pedal connectives oceur at fairly regular intervals throughwut the entire length of the animal. The labio-buecal ganglia are located at the sides of the pharyox a short distance behind the level of the salivary glands, and are united by at least one ventral commissure. In the posterior end of the luxly the relations of ganglia and norves are not especially clear, but the perlal corls appore to end in small culargements, united with the temination of the lateral ganglia by one or two slightly enlarged connectives. As usual nerver pass inte the hinder part of the anmal from the ends of the lateral ganglia which are united ly the usual suprarectal commissure.

\section{GWNERAL CONSIDERATIONS.}

If unanimity of appinion be any criterion whereby we may judge the correctwess of a theory it must be admited that we are yed a long way from the solution of the origin of the Mollusea, for saredy any two investigators hold identieally the same visws. In their development or in their adult organization many of the members of the phylum exhibit features which are the close comterpart of others in the flatworms and amelick and it may well be that, generally speaking, those studentis are compect who holel to the idea that all have descended from a common ancestom, though the details of the process are most obseme.

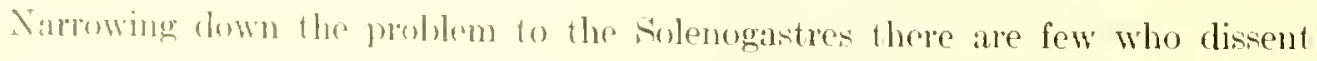
from the opinion that they are ture molluses, though it eamot be said their pusition within the group in defnitely established. Howerer it is beeoming 
increasingly evident that they possess mole whateders in common with the Chitons than with the other elsises, and these characters, interpreted in the light of community of descent of the two groups, ane more readily understood than from any other viewpoint.

It is little more than waste effort at the present time to athempt to reconstruet the external characters of the ancestral solenogastre, for it is generally agreed that the present day species, worm-like in form and without shell or well-developed foot, are highly modified in these respects. The aggravatingly few facts of their embryology are also without much value for the solution of the problem. As the matter now stands there is no positje evidenee that they ever had a shell, but in view of the faret that these animals show a close resemblance to the Chitons in several other respeets it is not unreasonable to believe that one was formerly present. It must bo admitted that Pruvot's figure and deseription regarding the shell in the larvae of Dondersin banyulensis are very indefinite, and have led some authors to elaim that the seven valves of the dorsal side are in reality greatly enlarged scales. There are some ovidences that such is inded the ease in the young of Holomenia gravida, at all events the plates do not develop exactly as does the Chiton shell. It is possible that we have here the confirmation of Bhumrich's theory that the original shell arose by the exeessive development of flattened spines along the dorsal surface of the animal.

It is a significant fact that the mantle of the Solenogastres has no counterpart save in the Chitons. In the least modified condition it consists primurily of a single layer of epithelial cells overlaid by at cuticular" covering often of enormous thickness. Those probably responsible for the formation of the cuticle, and of pigment when such is present, are comparatively simple, unmodified, more or less columnar cells. At frequent intervals throughout the layer spiculematrix cells arise and develop a single stratum of spines, or several layers imbedded in the cuticle. In their mode of origin the spines of the solenogastres are essentially similar to those of the ('hitons (see p. 29). Thiele declares that the Solenogastre spicule is produeed from one matrix cell, but this method is certainly not frequent, and Plate states that it is rare anong the Chitons. Wiren reports that in Chaetoderma there is one basal cell and three smaller ones encompassing the young spine. Hubrecht discovered that in Proneomenin sluiteri the base of each spieule is grasped by a considerable number of matrix cells, and as the spine is carried outward by the continued growth of the cuticle they continue to retain their attachment for a long period. Pruvot (90) finds in a few species that during the early development of the spicule four or five cells 
ans in contal with it, and the attanchent may persist for a comsiderable period. In P'romenmenin handionsis and a numbere of other species I have found that

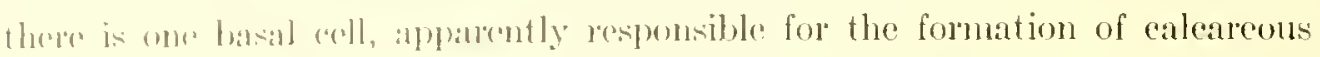
matcrial, surrumeded by soren or cight smaller colls attached also to the base of the spine and perhatps responsible for the formation of the eutieular sheath. This last named mone of formation is almost the exact duplicate of the most mommon mothod of spine development of the Chitons (Plate, 1901, p. 372).

Among the ("hitons the matrix eells retain their eomnection with the spicule as long as it exists. In the ('hactodematidale, and in those Neomenina with a single layer of spines, there is a tendency to follow this primitive method. The sann is true, though in some cases to a more limited extent, in a few species with thick cutiche and several layers of spieules, notably $P$. hawaiensis and Silomphomenia semulens.

The batkon-shaped parpillate developed from the hypodermis and in a fully developed comblition extending to the frese surface of the cuticle are of problematical significance. It has heen snggested (Kowalevky \& Marion, Wiren) that they may be spicule-matrix cells that have assumed some new function after the formation of the spine; but the fact that in P. hawaicnsis the matrix cells retain their attaldment, at least in part, as long as the spine is imbedded in the cuticte, prectudes such a positulity. In Alexandromenia there are many times more spines than papillae. Ilenseher on the other hand deseribes their origin as simple outgrowths of the lypodermis. Regarding their homologue in the ('hitons nothing may be elaimed definitely. They may correspond to the parckets or papillate (Plate) or, with a greater degree of probability, to the aesthetes as several authors have claimed.

That a foot of much larger size existed in the aneestral Solenogastre and that the ventral groove of the Nermeniidae does not "represent the first stage in the formation of that pedal surface of the body which is seen in the lowest molluscal" ((icgenbaur) is indicated by a number of facts. In the first place although no extemal trace of a foot exists in the Chactodematidae there is a space along the mid vental line between the lomgitudinal somatie museles which :ure theker here than elsewhere, and in limifossor this same space is oceupied by a simus exactly similar to the peclal simus of the Neomeniidae. In Limifossor the pedal sinus anteriorly penctrates a clearly defined septum and communieates with the hadd cavity as in the Chitons. It is much more reasonable to eonsider that the pedal sinus is the remmant of the foot of the aneestral Solenogastre than that it is the first sign of the appearance of a definite ereeping surface. 
In the Neomenima there is the same cleft in the rentral musculature, thiekened as in the Chactodermatina, and the foot is present as a small fold extending along the mid ventral line. Anteriorly it affords an outlet for the enormously developed anterior pedal gland which in position and developuent as far as this has been traced (see Heath (05), is homologous with the pedal gland of young Chitons. The remaindes of the foot is supplied with the posterior pedal glands which are present in a liffuse condition in the Chiton foot.

In the Solenogastres there are no eyes, tentacles and even the proboses or snout of the Chitons is believed generally to have no homologue in the group. Conceming this last named organ however Thiele elams (and in this he is followed by Nierstrasz and Pelseneer) that it is present, though in a highly modified condition and I an strongly convinced of the foree of his argument. In the first place it is a well-known faet that the first section of the alimentary canal in the Neomenima contains the atrial ridges (Mundleisten) and the enelosed cirrose area, all imnervated by fibres originated direetly by the cerebral ganglia. In Rhopalomenia aglaopheniae, Dinomenia hubrechti, etc., and I have found the same state of affairs in Driomenia pacifiea, this portion of the canal exists in the form of a depression in front of the mouth, and is separated from it by a narrow bridge of spicule bearing cells continuots with the general covering of the body. Owing chiefly to its innervation Thicle considers that this "sensibles Itrium" is the homologue of the Chiton snout which is now withdrawn into a depression. Where this atrium is a direet part of the digestive tube the true mouth has been drawn into the body and is located immodiately behind the most posterior atrial ridge. It now becones an interesting fact that in the Chiton development the mouth at first is posterion to the snout and but slowly takes up its final central position (ef. Ifeath '99). It lends support to the belief that in these molluses with isolated atrial "avity the position of these organs does not represent a highly modified eondition but a relatively primitive state of affairs.

In the Chactodematidac the nerves which originate from the anterior surface of the brain pass at once into the huge, compact ganglionic bolies homologous, I believe, with the more diffuc nerve masses in contact with the basses of the cimi and buceal sensory jidges in the Neoneniodac. From these a relatively enormous number of fibres pass into the Mundichild or buceal plate, just as the cirri and ridges are innervated by nerves from the neighboring ganglia. There is thus little doubt that the buceal plate and sensory atrim are homologous and if the above line of reasoning be correct, they are the homologue also of the Chiton snout, which is likewise innervated by nerves from the cerebral ganglia. 


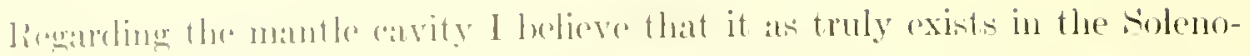

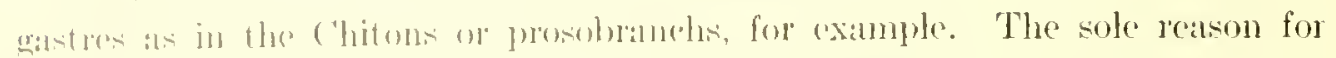

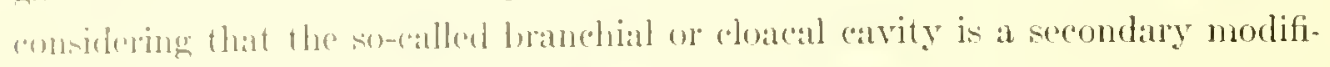
sation appears to hawe whedly originated with Thiele who clains that the bran-

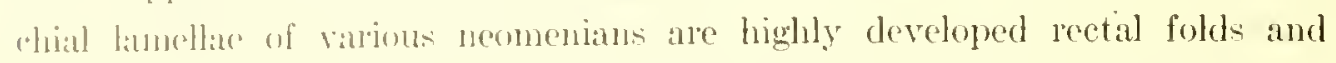
acordingty the branchial waty is not hing more than a greatly expanded rectum. The sume is true of the (haretodermatilae, for the phume-like revpiratory organs atre sidid to have been dereloped from similar rectal folds, and accordingly their remarkable recomblance to true conidia is of no especial signifieance. Furthermore the fact that the nephridia open into this space is likewise of no importance for it is of enenegenetic origin.

Regarding the branchial plates of the Neomeniina, they cortainly have every alprearance of being merely folds of the walls of the branchial cavity, but that they alre chosely related phylogenetically to the respiratory organs of the Chatodermatidate is an contirely different matter and one nost difficult to substantiate. On the oflere hand it secms to me that the gills of this last named family are not "harly homologous with the neonenian respiratory organs. In a former paper I have called attention to the fact that in gross and microscopic appearance, bleme supply, and innervation they are practieally identical to the Chiton gitl. sueh an idea lninge us whthout violenee to the belief that in the original aneestor of the folenogastres and ('hitoms there was a true mantle cavity containing at least two ctenilia, the separate outlets of the urogenital system and possibly an osphradium though such an organ may well have been in a diffuse condition ats in some of the modem lamellibranchs. Aceordingly the conneetion between the pedil furrow and the mantle cavity is not secondary but primitive and similar in its brouler foatures 10 what is found in the Chitons. The polybranchiate chamater of this last named group yet remains a puzzle for as I have pointed out (0i) there is nothing in the development of these organs to indieate if it be primitive or not.

While several funtemental differences between the circulatory systems of the solenogastros and the Chitons have been found to exist these may be explained to some extent on the supposition that originally the foot was of larger sizc, and in any erent they do not ontwejgh several remarkable resemblances. In both the perieardium is dorsal, posterior, and communicates with the exterior with paired duets. In present day species it contains the heart, a simple tubular organ or differentiated into a ventricte and single auricle, which may originally lave beren paired as Wiren has ingenionsly suggested. From the anterior end 
of the heart the arorta arises and passing along the dorsal side of the gonal, that it supplies in Chiton-like fathon, it reathes the houd catrity. In the great majority of species this last named organ is not cleary defined, hut in Limilosion it is separated from the visceral wavty by a conmective-tissue septum as clearly defined as in the Chitons and having essentially the same relations. Within the head sinus the blood makes its way by irregular channels into the visceral cavity and passes backward. In Limifosor the septum is perforated ventral to the intestine and through this the blood nakes its way into the ventral sinus. A special viseral artery or sinus is lacking within the group, its function being taken by the general viseeral eavity and vontral sinus. This last naned space communieates freely at many points with the visceral cavity and posteriorly both unite and the combined vessel makes its way to the ctenidia and from thence into the heart.

Hansen years ago noted the presence of crystals in the coelomolucts of Chactodema, and considered it possible that they may function as kidneys. From much nore extensive studies Wiren has taken the sume position, showing the elose similarity of the tissue to that of the Chiton kidney. Mnother fict of the greatest importance is that in Chactoderma crudita for example, where the sexes are separate the nephridia of the male are exactly the same as those of the female. If the coelomoduets here act in the capacity of shell, mucous or other glands intimately conneeted with the egg-laying process it is reasonable to suppose that it would be more highly developed in the female than in the mate. Since it is not it becomes much more probable that the resemblance of the cells of the duet to those of the Chiton kidney is not areidental, but that they are true excretory elements and the ducts therefore have retained the excretory function derived from the ancestral form.

Stating the matter in another way it appears that the coremoduets are, from the standpoint of both structure and function, of a more primitive chanacter in the Chaetodermatina than in the Neomeniina. In the latter family the duets have assumed an important role in the storage of sperns, or in the development of envelopes for ova and perhaps other procestes commected with egg-laying, so that the original function of excretion is effectually masked, if it exist at all. In the Chitons the kidneys become aetive excretory organs long before any trace of the gonad or its duets appear, and if these tubes in the Neomeniina art as kidneys they likewise would probably assume their duties at an early stage. In Dorymenia acuta, however, there are no signs of such activity in individuals $14 \mathrm{~mm}$. in length. The reproductive glands are present, though in a very im- 


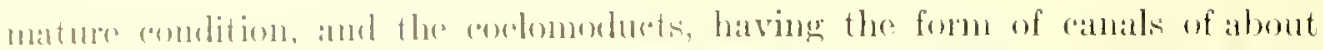

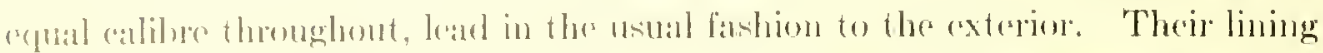

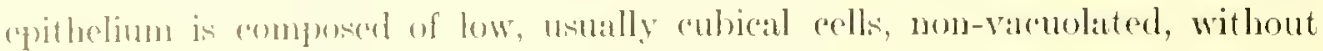
any traces of conchements on crystals, and indications of any ghandular activity

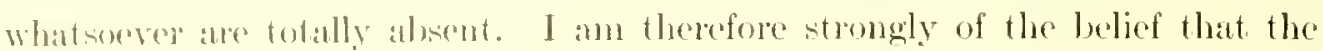

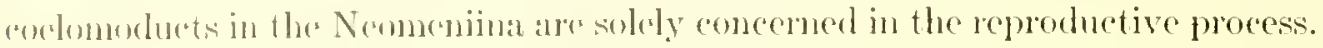

Ciranterl that the seretion of the alimentary canal, including the cimose atrea and the huceal semsory rielges, is the homologue of the ('hiton snout, or at all cyents a comparatively late formation, the remaining portions are decidedly ('hiton-like. In most species there are both dorsal and rentral salivary glands which slow a surprising amount of variation, ranging from seareely distinguishablu bolies to others of great size and a high degree of complexity. As in the case of the (thitoms the dorsal set typically opens through the dorsal buecal wall white the outlets of the ventral parre are in the neighborluowe of the radula.

'The ralula, in at number of speceses is lacking, and in several others it is in a degenerate state, being resluced to a peg-like body (Chactorlema) or to a very few teeth which are reported to lack a basenent membrane. On the other baml there are species, subh as Limppomenia (Nierstraz, 05) and Limifossor (Iteath, '05) which have typical radulare, as regards loeation and component parts. Odemtolblasts, colks which form the basement membrane, and cnamel cells are all present, and the resomblance to the radulae of other molluses, as figured by Rossler for example, is surprisingly complete.

The fate of the subrudulat organ anpears to depend dosely upon that of the raclula. In every case that has come under my observation it is lacking or is reduesed to the merest rudinent when the radula has disappeared, and in some species it is in a highly degenorate state whon the radula is in a similar comelition. It is fo be noted that the nerse supply to this organ may be a mued more conservative set of organns, porsisting in strophlomenum seandens, for cxample, after the organ has coused to exist as a well-defined structure.

The linnits of the mosterior end of the pharymx and consequently of the

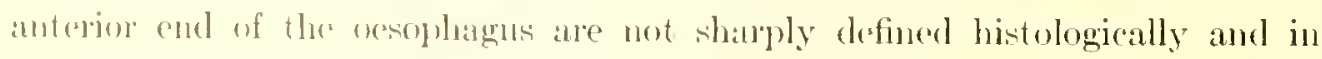
the alsence of mulnylogiral evidene they remain problematieal. In fact the

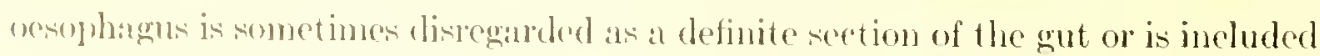
in the tescription of the phargux. In some speeies it appears to be bounded antrionly ly a cireular fold and posteriorly it is probably terminated at the rommencement of the stomanh-intestine.

"The intestine is elifferentiated into a well-defined stomach and intestine, 
in the Chatodermatina and as is well known this latter organ is practirally straight. In the Neomenina it is unirue in postessing an anterior dorsal coecum that extends forward to the neighborhood of the brain; and the liver is not shapply differentiated from the gut. The opening of the restum into the mantlo eavity and its relation to the nervous system may be derived without sarions difficulty from a condition similar to that of the Polyplateophora.

In their broader features the nervous systens of the Solengatres are all redueible to one type, as Thiele and Nierstrasz maintain. In practically every species described in the present paper, the brain is bilobed and always conneets with the pedal, lateral, and labio-bueeal systems. In the Neomenima three pairs of nerves, often associated with small ganglia of problematical homology, are distributed to the anterior end of the body and attach to mumerous ganglionic masses applied to the walls of the atrial cavity. In the Chactodermatina a larger number of nerve bundles arise from the anterior surface of the brain and connect with great ganglionie bodies often alnost enveloping the brain. From these ganglia branches pass to the buceal plate. Judging from its innervation the atrial cavity is thus the lomologue of the buecal senory plate (Mundschild), and both are homologons with the Chiton snout. Aceordingly the ginglia attached to the brain are the eounterpart of those applied to the bascs of the cirri. Thicle has called attention to the inappropriateness of the term "buceal" in speaking of these ganglia, and aceordingly the term precerebral may be used.

In a primitive condition the lateral, pedal, and labio-buecal connectives probably arose as independent trunks, but in many species they are nure or less fused for some distance. The ventral and pedal ganglia are usually (nlarged at the point of union with the connectives, and may origmate norves distributed to the walls of the pedal-gland outlet, atrium and to some extent of the body. Commissures at faily regular intervals attach the perlal ganglia and may develop small branches distriluted to the tisue in the vicinity of the ventral fold or foot. About the same number of eomectives mite the pedal and lateral ganglia, and likewise give rise to small off shoots passing into the somatic musculature. Other nerves, with seemingly the same destination, form from the upper surface of the lateral ganglia and course dorsally. In the posterior end of the body the lateral ganglia usually enlarge and invariably are united by a suprarectal commissure. From these enlargements branclies pass to the body and cloacal walls, and from the commissure in the mid line a fibre arises, in some species, that is distributed to the dorso-terminal sense organ. 'The pedal ganglia may gradually diminish in size posteriorly or become attached 


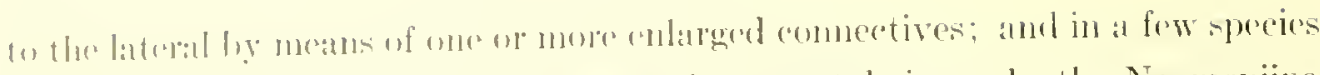

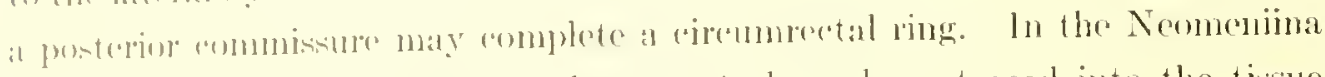

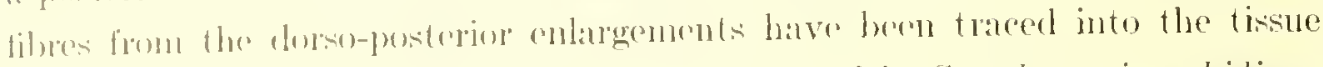
surromeling the sherl gand, into the hody walt and in Strophomenia ophidiome dolicate nerves have been traced from the entargements of the lateral ganglia inte) the heart. In the chartentermatidac practioally all of the nerves inner-

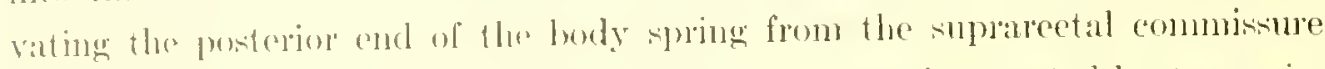
or in clese forexinity to it. In limifostor the gills are innervated by lwo pairs

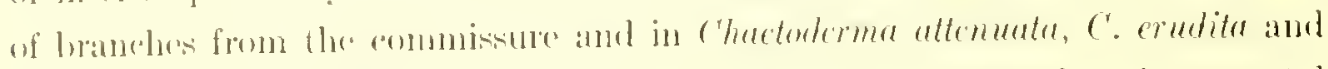
probalbly others the sane is true. I have been unable to find a circumbectal rimg dereribed by Wirne (92).

Tho labio-buceal system has been examined critically in a fow species only, root the few facts gleaned indieste that in a typical condition it is not unlike what is fommel in the chitoms. For many yours the sorealled buceat ring has been known both in the (hactodomatina and in the Neomeninat, consisting of two eomnectives coursing along the sides of the phargnx and uniting with two ganglia in the neighborhond of the ladula or the ontlet of the ventral salivary glands. These anglia, which I have termed lahio-huecal, are in turn connected by means of a rentral eommiswure, which in the gents Chactoderma bears two small ganglia. In Pronomena handionsis there is a very distinct subradular organ, consisting of two chenty defimed cireulas patches of high epitheliat celts on each side of the mid line in front of the radula. In close proximity to these are small ganglia, unitod by at commisure, and on the other hand joined with the labiofuceal ganglia by comnectives. In addition there is a dorsal commissure uniting the labrio-buceal comnectives and possibly another ventral one. These same elements in a more compact form, exist in strophomeniu seandens. In the genus chaefoderna I have recently shown that in front of the ladula eonnectives attached to the babion-buceal comnectives, and, after giving off nerves which pass dipecty to morlified egrithelial pateh in the pharyax, are united with a single sanglionic mass. In Limifosson there is in addition to the well-known eommissure a dorsal one and problully a seond ventral one. In Dorymonia acuta there are two dorsal commissures and two rentrat, one of which beats a pair of smalt grangliat. The radula is certainly in a degenerate condition in several species of solemogastres; it flats disappealled in others and the same extremes exist in the ease of the subradular organ. Consequently it is not remarkable that the sycten of wangliat and nepres associated with these sensory aneas exhibit marked differences in the various speries. 
Comparing the labio-bucal systems of Proneomenia hauriensis and a Chiton (Trechydermon raymondi) it is seen that in the folenogastres the connectives attaching the subradular, buecal, and labial systems with the brain are of great length; in the Chitons they are very short. In the Chitons the buceal ganglia are clearly differentiated; in the solenogastres they are fused with the labial. These homologies have been treated in another paper (Heath '05), and offer, so far as I can see, no serious difticulty.

Nerves from the labio-buceal ganglia have been seen in both of the divisions of the solenogastres to pass into the pharynx which they doubtless innervate. In Chuetoderma cruditu they have heen traced as far as the end of the pharynx. In the Chactodermatidae practically all of the nerves innervating the posterior end of the body arise on the suprarectal commisture or in close proximity to it. In Limifoswor the gills are innervated by two pairs of branches from the commissure and in Chatoderma altenuata, C. erudita and probably others the same is true.

While the facts diseused in the foregoing paragraphs appear to justify the conchusion that the solenogastres are most closely reluted to the Chitons, they do not as eertainly settle the question as to which group has retained the greater number of ancestral characters. The condition of the cockom in the first named division appears to be very primitive and probably palingenetic; and, generally speaking, the musculature is more simple, and this is true to some extent of the digestive tract, though these may have been secondarily modified. The absence of a shell and well-developed foot, the relatively simple condition of the cireulatory apparatus, the concentration of the nervous system, and, in the Neomeniina, the high degree of development of the coelomoducts point more clearly to modifications of a more primitive type. Without entering into further detail it would appear hat, with the data now available, the Chitons are to be considered the more prinitive, in fact the most primitive of all molluses. 


\section{BIBLIOCRAPHY.}

[i, III], II

68. Nomegraph of the speries of worms belonging to the sulutass Gephyrea; with a

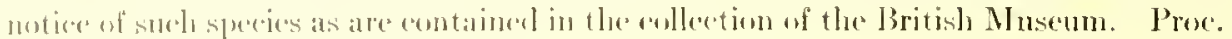

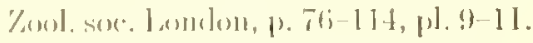

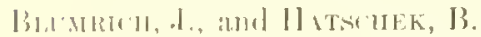

'91. 1)as intugument dep (hitonen. zait. f. wist. zool., 52, p. 404-470, pl. 23-30.

lim $1 \times 1,1$,

1900. \%omlogio descriptive. Mhollusques, 2, p. 307-591.

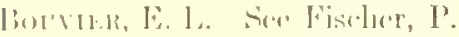

li!nk k, .I.

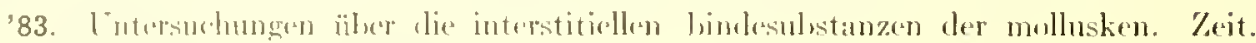
l. wist. 2ool., 39, p. 1- tip, pl. 1-4.

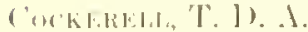

1903. Somb homonymons gemeris names. Nimtilus, 16, p. 118.

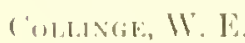

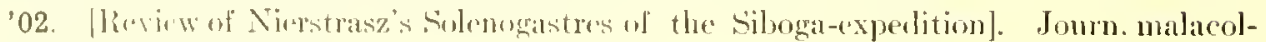
$0,9,1), 10.51116$

I)IIYILI, I. (;.

'51 58. The puwers of the croator, ete. Buls., Lombon.

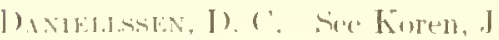

IIISivi, li, M

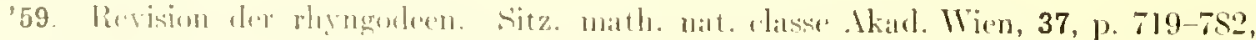
11. 1-?,

1) 1:H, (i, , i.

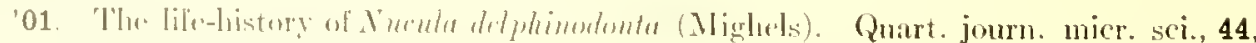

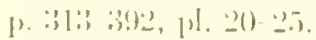

lililuvili, li, y.

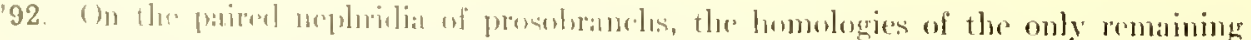

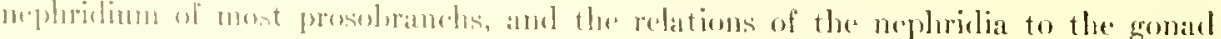

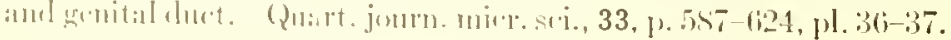

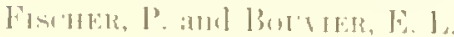

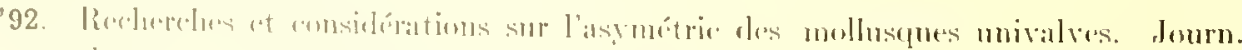

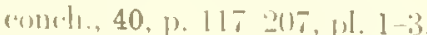

(i)kisini, II

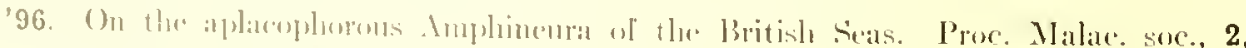
p. 1:3-1:5, [1. 10. 
Gegenbaur, C.

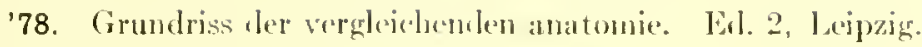

GRAFF, I. V.

'76. Anatomie ales Chatoderme nitidulum, I sovén. Zeit. f. wiss. zoul., 26, p. 166-192, pl. II-13.

77 Neomenia mol chatederma. Zeit. f. wiss. zool., 28, p. 557-570.

GroвиеN, K.

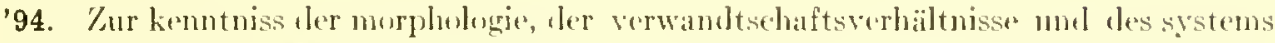
der mollusken. Anz. Akat. Wien, 31, p. 24-25. Sitz. math.-nat. classe Akad. Wien, 103, p. (il-s6.

HAECKEL, l:.

'96. Systematisehe phylogenie. 2, Berlin.

IALLER, I3.

'82. Die organisation kel chitonen der Arlria. Arl. Zool. inst. Wien, 4, 44 pp., 5 pls.

'89. Boiträge zur kenntnis der textur des central-nervensystems hïherer wiomer. Arb. 7ool. inst. Wien, 8, p. 175-312, pls. 16-20.

'94. Beiträge zur kenntnis der placophures. Norph. jahrl,., 21, p. 28-39, pl. 2.

IIINSEN, G. A.

'77. Anatonisk leskrivelse al Chutoderma nitidulum, Lovén. Nyt mag. l. natur., 22, p. $354-377$, pl. 1-i.

'88. Neomenia, Proneomenia and chä̈toderma. Bergens mus, atarsheretning, 12 plo, $1 \mathrm{pl}$.

HAtschek, 13. See BuUMrich, I.

НЕАТН, H.

1904. The habits of a few Solenugastres. Zool. anz., 27, p. 457-461.

1904. A new genus and species of Sulonogastres. Zoul. anz., 28, p. 329-331.

1904. 'The nervous system and subralular organ in two genera of Sulenugastres. Zool. jahrl,. Abth. anat. ont., 20, p. 399-40., pl. 27.

1905. 'Tlu morphology of a Solenogastre. Zool. jahrb. Mhth. anat. ont., 21, p. $703-$ 734, p). $42-43$

1908. The Solenogastre subradular nervols system. Anat. anz., 33, p. 365-367.

IIEUSCHER, J.

'92. Zur anatomie und histulngie ter Pronommia sluttri Hulırecht. Viesteljahrsselvr. nat. gess. Zïricli, 37, p. 148-16il, 4 figs.

'92. Zur anatomie unt histologie der Promeomonin sluitri Hubrecht. Jena. zeit. maturw., 27, p. 477-512, pl. 20-23.

HOLAGREN, N.

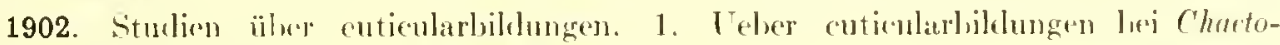
drrma nitidulum Lavén. Inat, anz, 22, p. It-20.

HuBRECHT, . 1. .. IV.

'80. Promemenia sluiteri gen. ot sp. n. eine newe arobaische molluskenform ans alem Hismerere. \%ool. : $1 n z ., 3$, p. $589-590$.

'81. I'romemeniu sluteri gen. et spr. n., with remarks upon the anatumy" and histulngy' of the Amphineura. Niederl. arch. R. zonl. Suppl., 1, 1-7is pp., pls. 1-4. 
HIt 13:111, .1. .1. II.

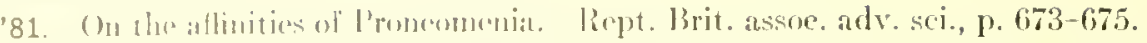

82. I contribution to the morphologe of the Amphineura. Quart. journ. mier. sei., $22,1 \%, 21: 2$.

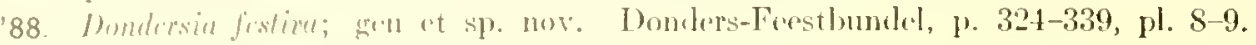

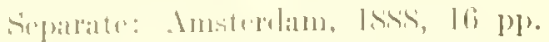

III:11:Ni, H. V.

77. Vorgloidemula anatomie des mervensystems und phylogenie der mollusken. larpig.

77. Buitrige zur kenntniss des nervensystens der amphineuren und arthroeochliden. Moruh. jaluli., 3, p. 1.5.5-17, pl. 10 .

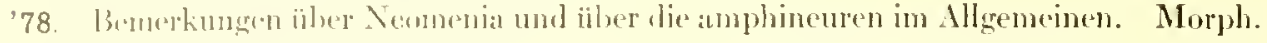
j:lirl., 4, P. 117 15\%.

Kenelsten, 11 .

65. Baiträge zur anatomisthen und systematischen kenmtniss der sipmenliten. Nichr. Königh. erest wist. (röttingen, p. 189209.

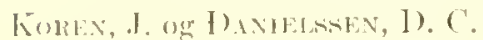

'77. Inskrivelse orer nye artor, henhrende til sliegten Solenopus, samt nogle oplysningere orn don organisation. Ard. P. math. og naturvidenstiah, 2, p. 120-12S.

'79. Wuscriptions ol new speres belonging to the genus Solenopus, with some observations on their urganization. Inn. mag. nat. hist., ser. 5, 3, p. 321-328. Translation lig. IT. Hiallas.

Lursinete, F.

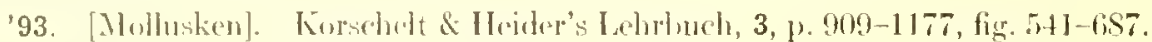

KIMULEYSY, 1.

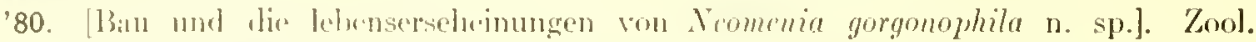
:เn\%., 3, p. 1!n-1!).

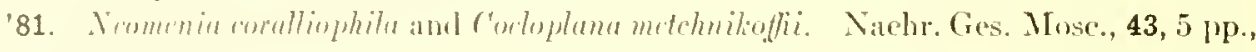
$\because$ pls. and Mtand, A. F

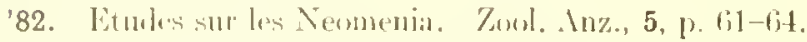

'87. Contributions al lhistuire des solenogastres ou aplacuphores. Amo. Mus. hist. nat. Marscille, 3. 7s pre, ph. 7.

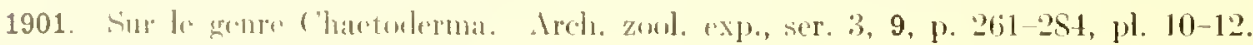
Sien Marion, . 1. 1\%

1.1.KKTTER, E. R.

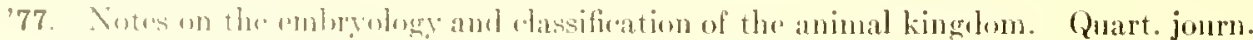

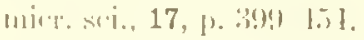

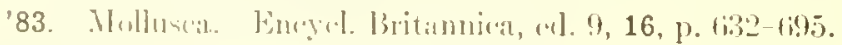
Iavi, s.

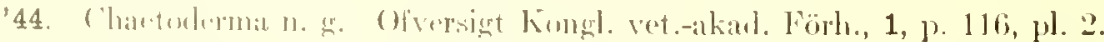
IIRIO), A. F

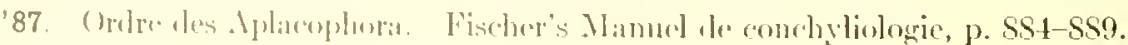

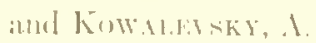

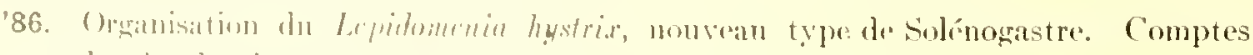

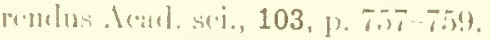

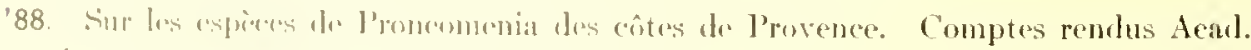

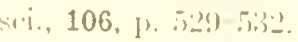




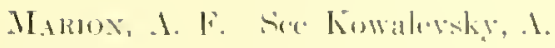

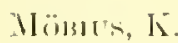

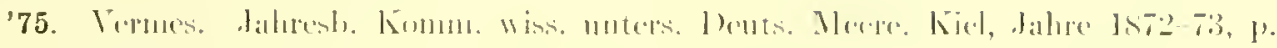
$15 i,-171)$, pl. 3.

NIEISTRISZ, 11, J.

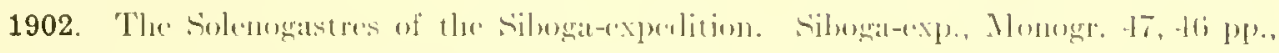
(i pls.

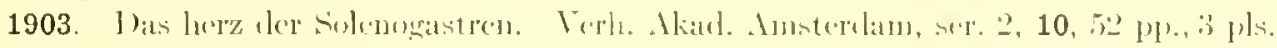

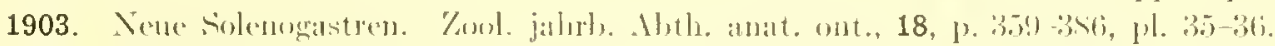

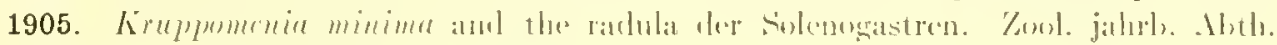

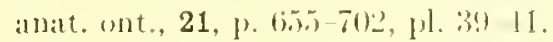

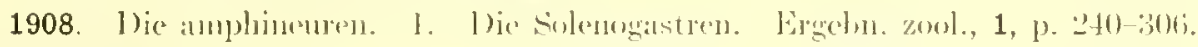

Nokatax, 1. M.

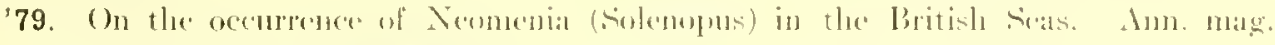
natt. hist., ser. 5, 4, H. liti loti.

l'ELEENEEU, I'.

'90. Sur le pied du Chitonellus et des Aplacophora. Bull. Sci. France et Belgipue, 22, 1. 45 ! 49.5.

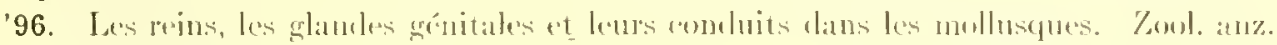
19. $\% .140-145$.

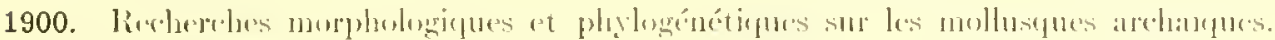

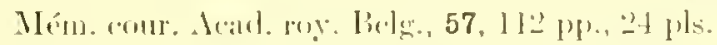

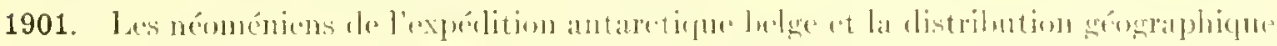

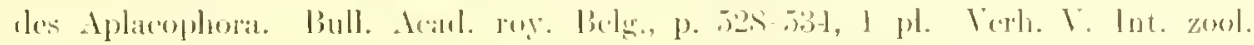
(coligr., p. $7 \div$.

I'ILABRT, 11. .1.

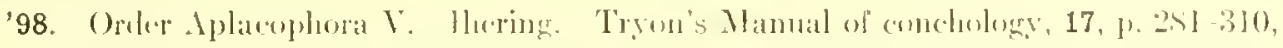
pl. $40-4 i$.

I’. ITE, I. II.

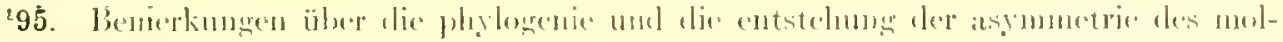

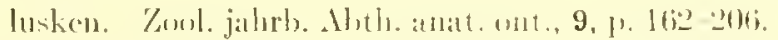

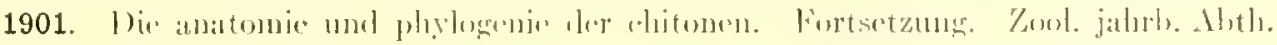
suppl., 5, 1. 2.\$1-600, pls. 12 16.

I'liciot, $G$.

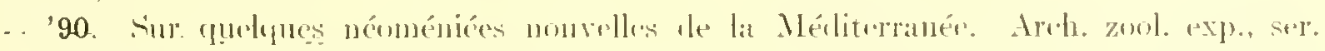
2, 8, Notess at rivine, 1). 21-24.

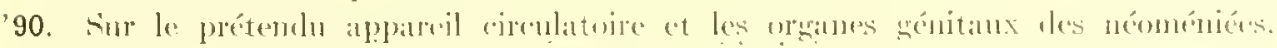
(omptes renclus Aciul. sci., 111, p. ig-tiz.

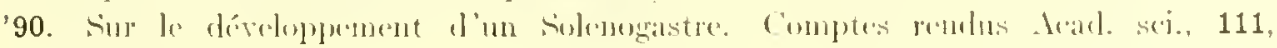
p. (is:) (i!):

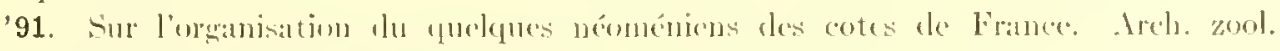

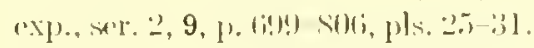

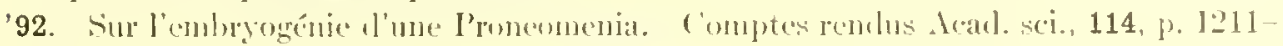
1211 .

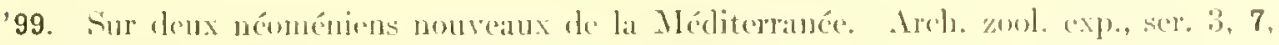
p. $4(i 1-510$, , l. ] -14 .

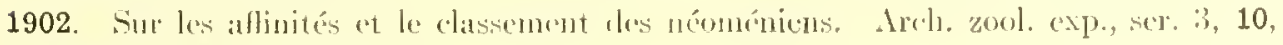
Nertes et reviues, p. S-27. 
(र) $1111116,1-1.111$

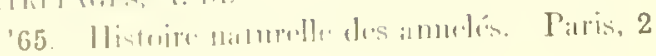

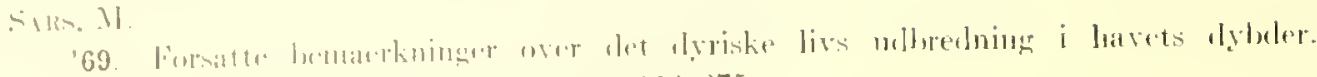

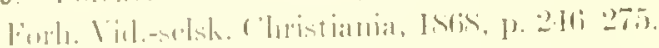

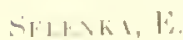

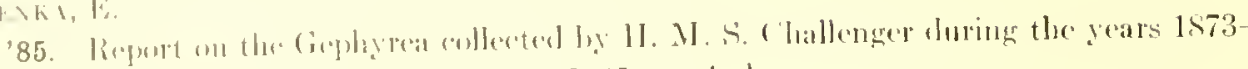

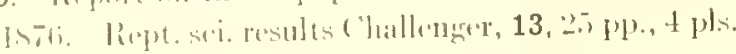

Siा1121111, II.

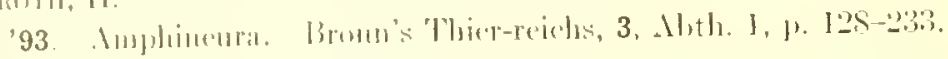

iinliul11, II.

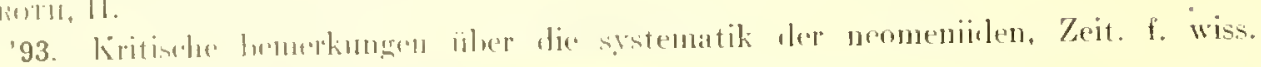

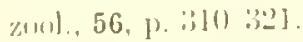

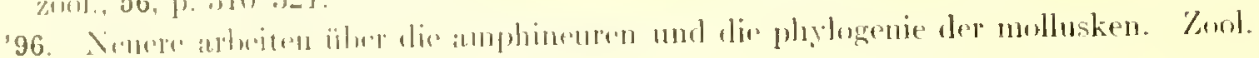

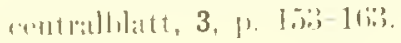

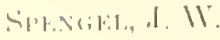

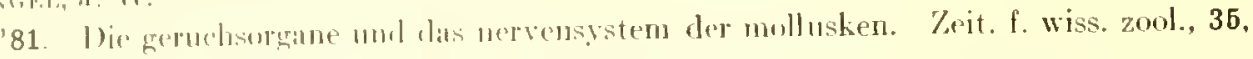
1). $33: 3,3,11 \div .17-19$

'Til. E.L, II.

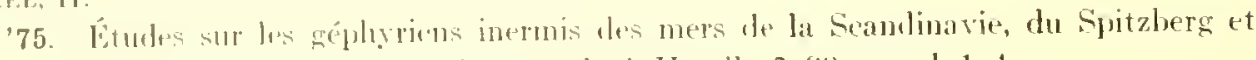

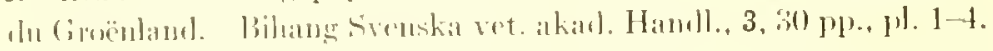

IHIHEF, . I.

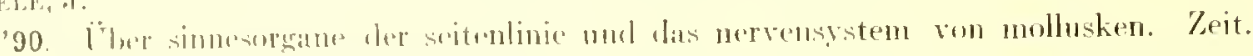
1. wiss. zunl., 49, 1\%, 355-132, pl. 16-17.

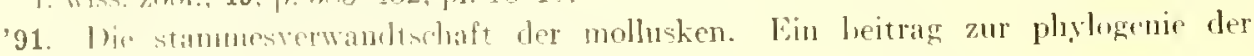

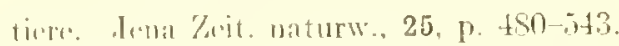

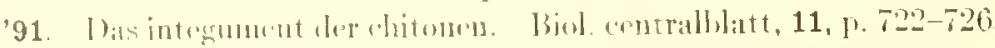

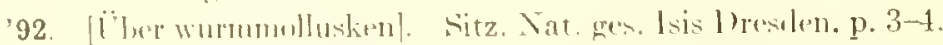

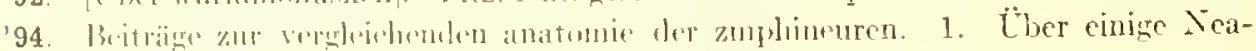

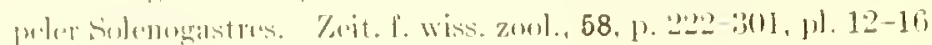

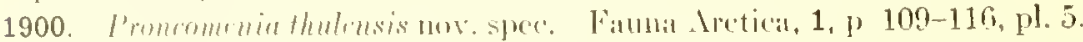

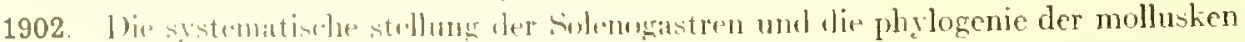

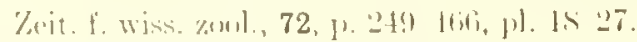

1902. \% (1) (iil)

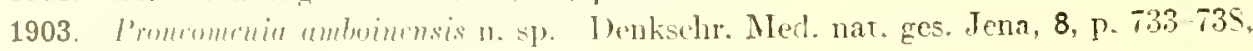
1). titi, figs. 5, 9

1903. Jronmmenia raldivac 1]. sp Wiss. crgeb. Taldivia, 3, p. 167-174, pl. 23

1906. Irchacommia prisca n. ..., n. sp., Wiss. ergeh. Talilivia, 9. p. 315-324, pl. 28.

1907. Pulyplacoploran mul Solenogastres für 1894-1905, Areli. f. naturgesch., 68. 2,3, P. $1-16$.

TullbFra, T.

'75. Nenmenia, a new genus of invertelorate animals. Bilang Svenska vet. akarl. IIandl., 3, $12 \mathrm{pP} ., \mathrm{pl}$. 1-2

TerRit 1., 1. T.

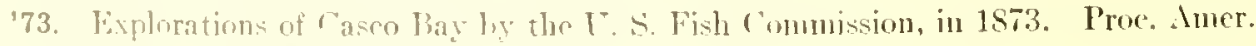
issuc . 22, p. $310-396$, pl. 1- 
WIREN, 1 .

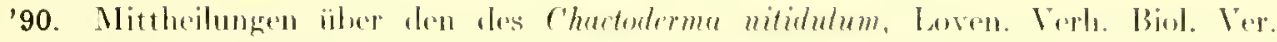
Sitockliolus, 2, p. $68-73$.

'90. Histologiska meddelanden an Chactorlerma nitidulum, Laren. Verli. Biol. Ver. Strokholm, 3, p. $37-49$.

'92. Sturlien iiber die Solonogastres. I. Monographie des Chactodermu nitidulum

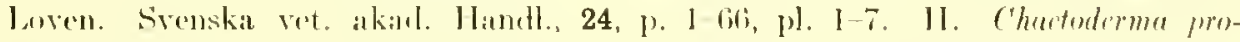
ductum, Seomenia, Pronomenia uruminata. Srenskal vet. akarl. Ilamll., 25, 1) 1-100, pl. $1-10$. 



\title{
EXILASTIOS OF THE PIATES.
}

\author{
it inus, \\ ator arotal. \\ al) antermer perlat glamel \\ 1) brim.

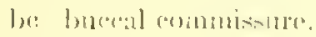 \\ l) Jabio-bureas ganglion. \\ br gill. \\ bern nerves to gills. \\ c intestinal commint \\ (1) Moaral witulure.

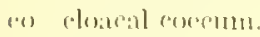 \\ ris romelomouluret. \\ lit dorsil aurtil. \\ dier alersal silivary ghamel. \\ fo bureal pliter. \\ gl glandio of pharrux. \\ (y)!r gunail. \\ lut lieart. \\ int intestinu. \\ lb. labio-bureal couneretive \\ liv liver. \\ in inumbly \\ n nerve to lineal flatu.
}

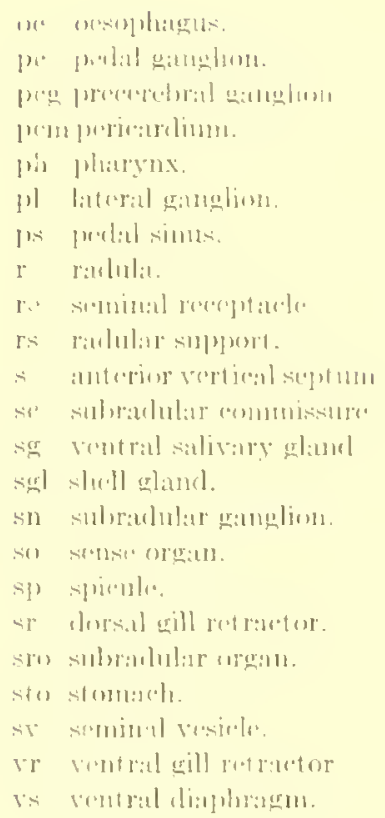



PLATE 1. 
PIATl:

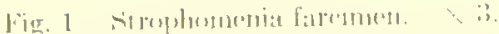

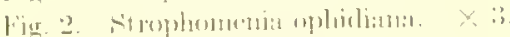

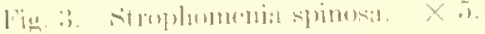

firg. 1. Ilempunemia platypurla. $\therefore$ 10.

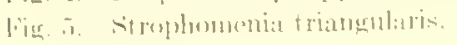



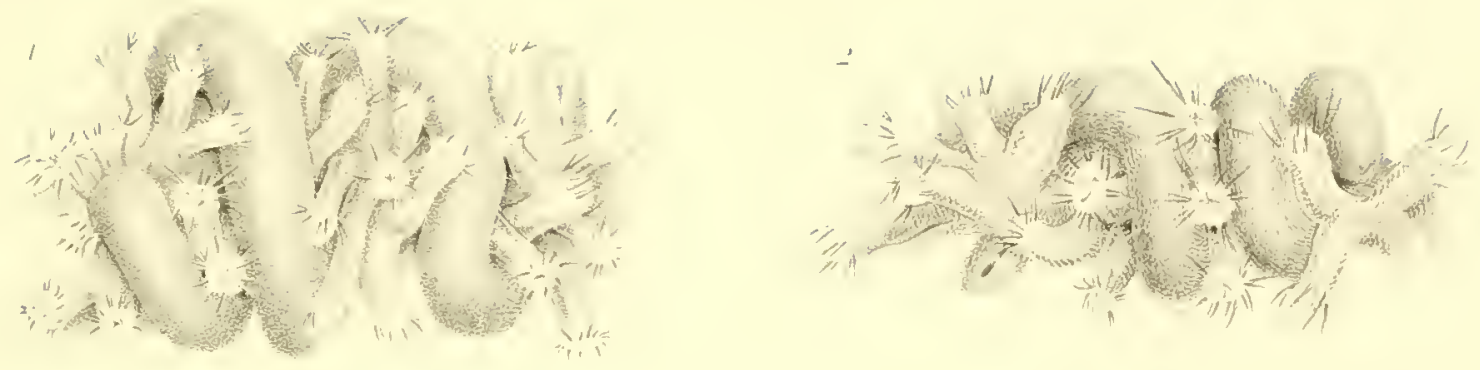

1. 
PLATE 2. 
HLATE 2.

Fig. 1. Strophomenia seanders. $\times 4$.

Fis. 1). Drenanomena vanpyrolla. $\times 7$.

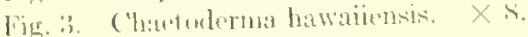

Vig. 1. Lophonental spiratis. $\times 7$.

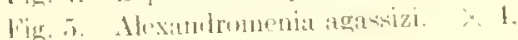

lïg. i. Limifossur frittula. $\times 5$. 

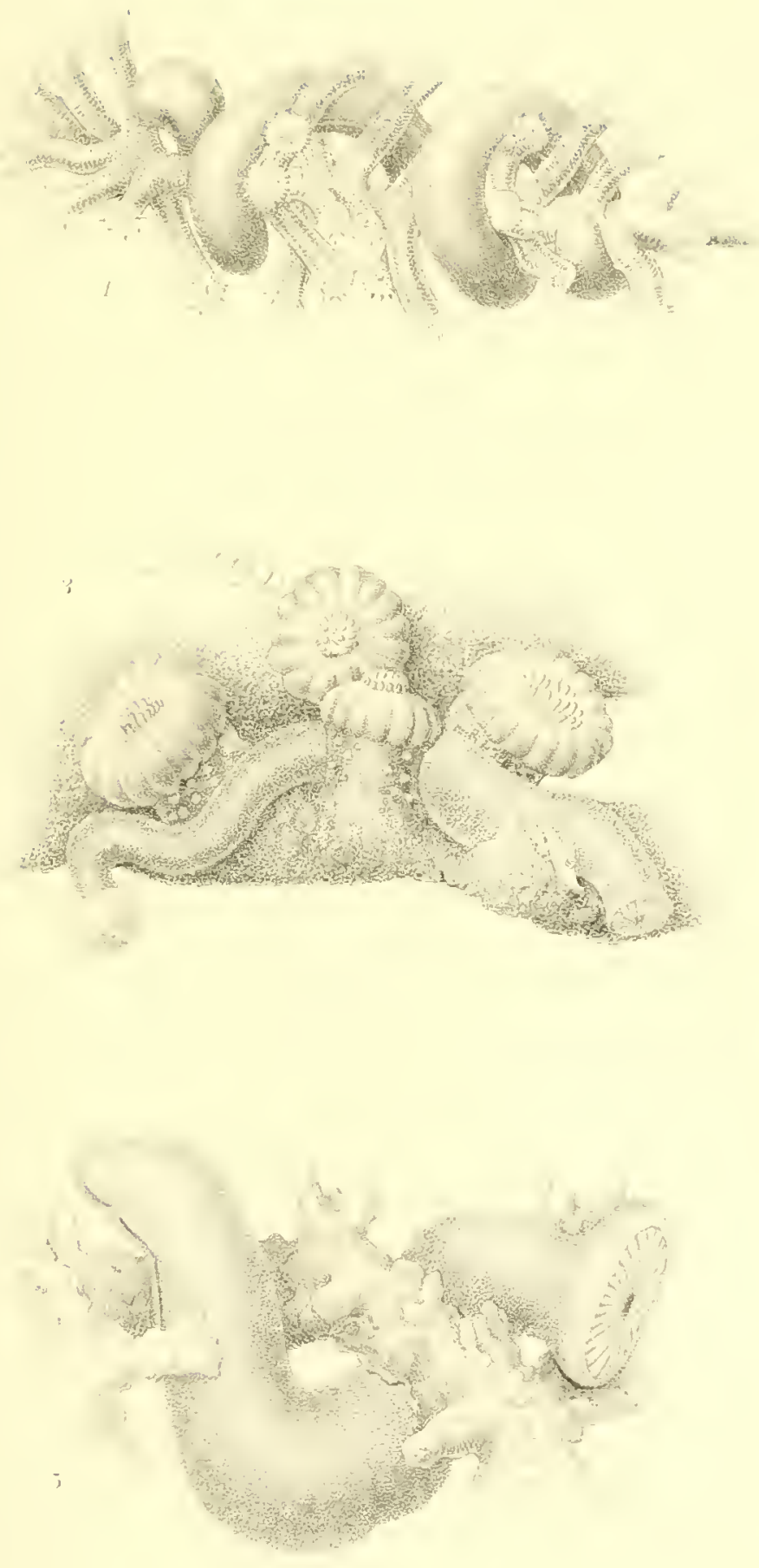
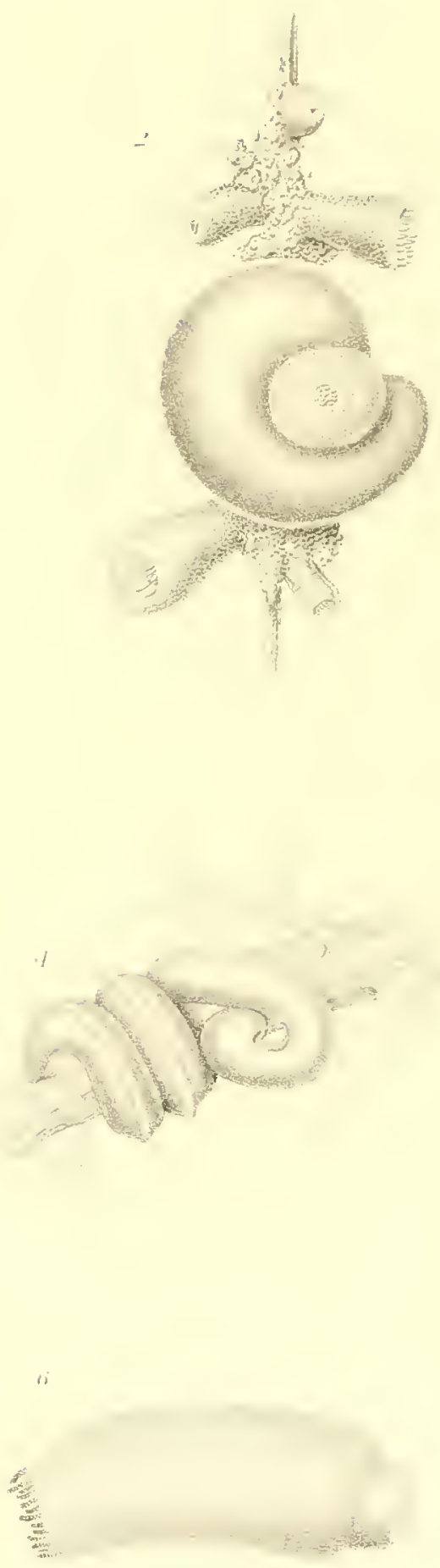

PLATE 3. 
I'TATH 3.

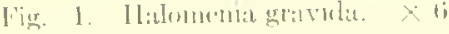

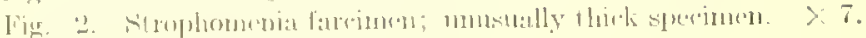

lige. 3. Meximlommonia valielat. $\times 3$

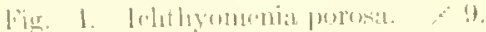

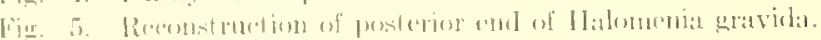

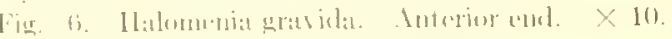

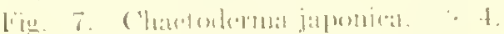

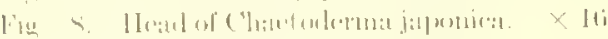

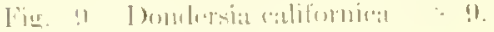

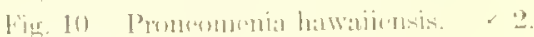

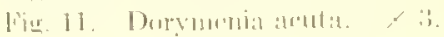



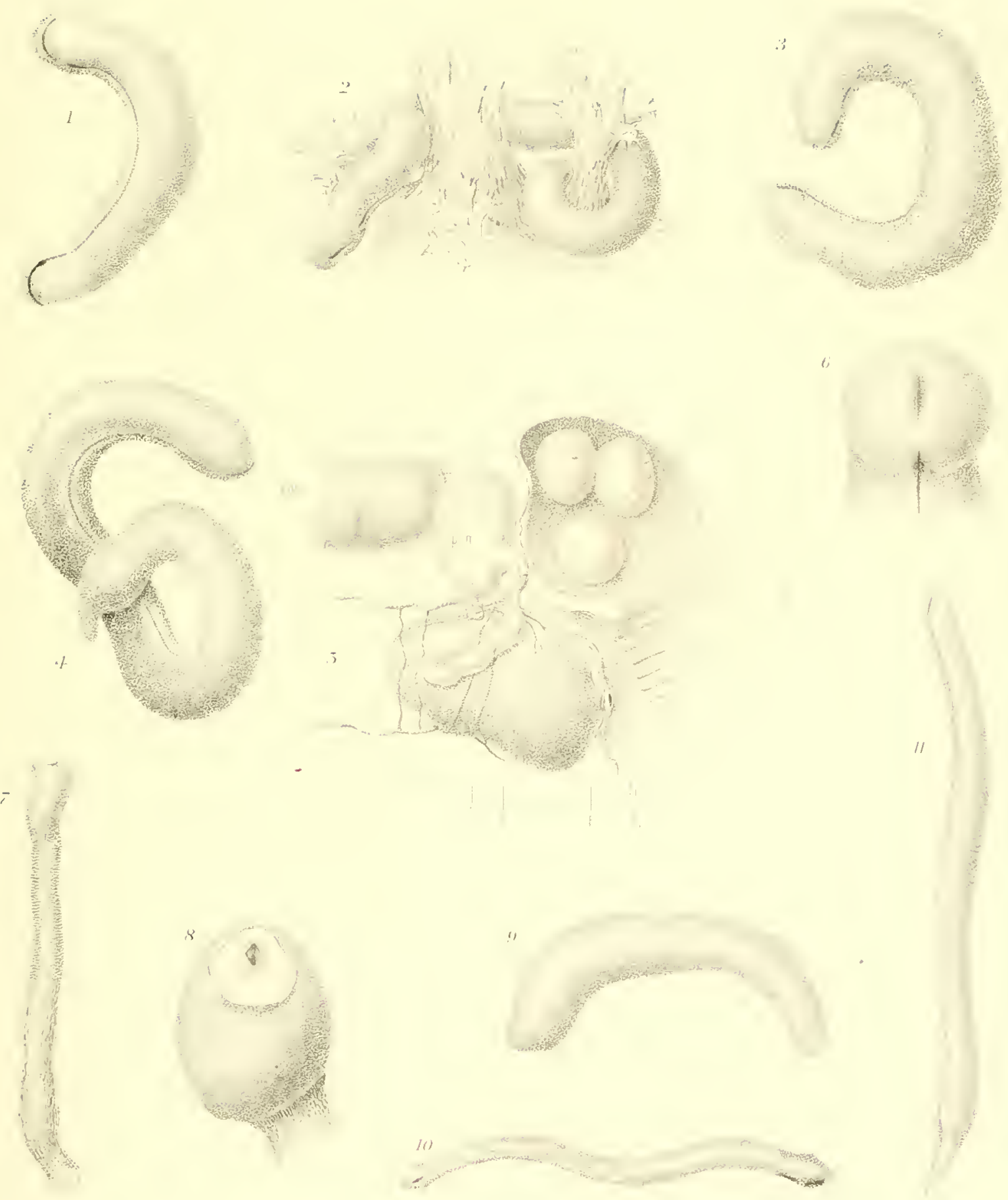

PLATE 4. 
P'ATE 4

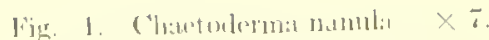

Fig. 2. ("latelulerma scibril. $\times 7$.

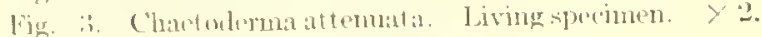

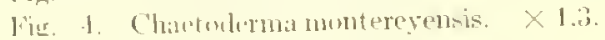

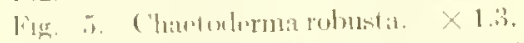

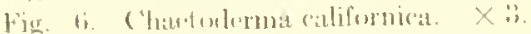

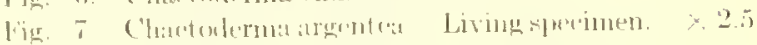

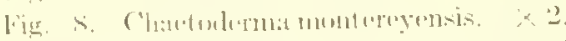

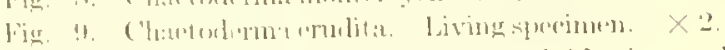

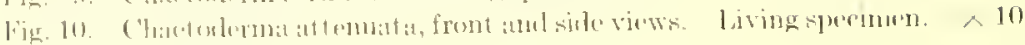

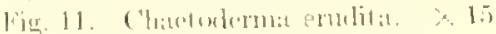

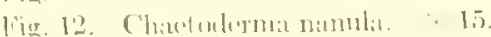

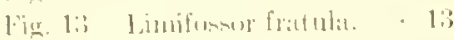

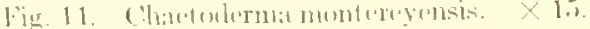

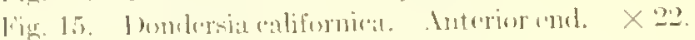

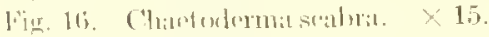

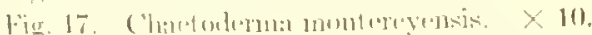

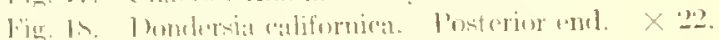

Fig. 1!?. Chencenterma rodustat. $\times x$ 


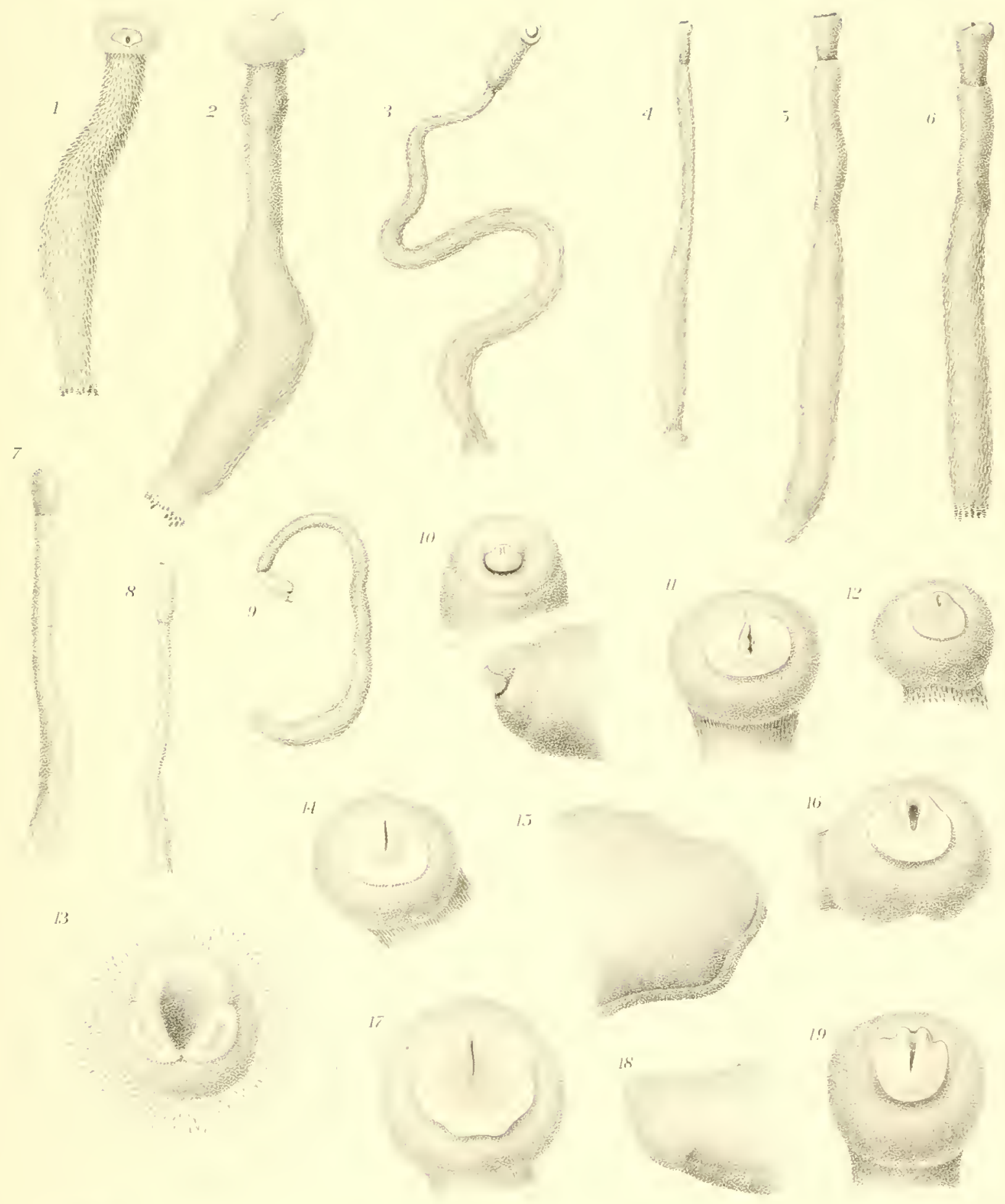




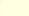


PLATE 5 
PMTTE

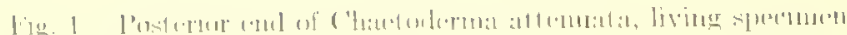

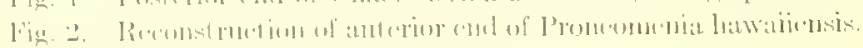

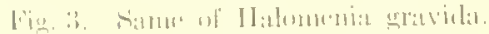

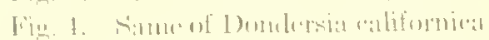

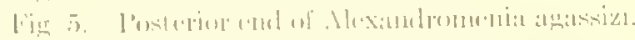

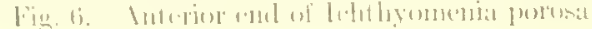



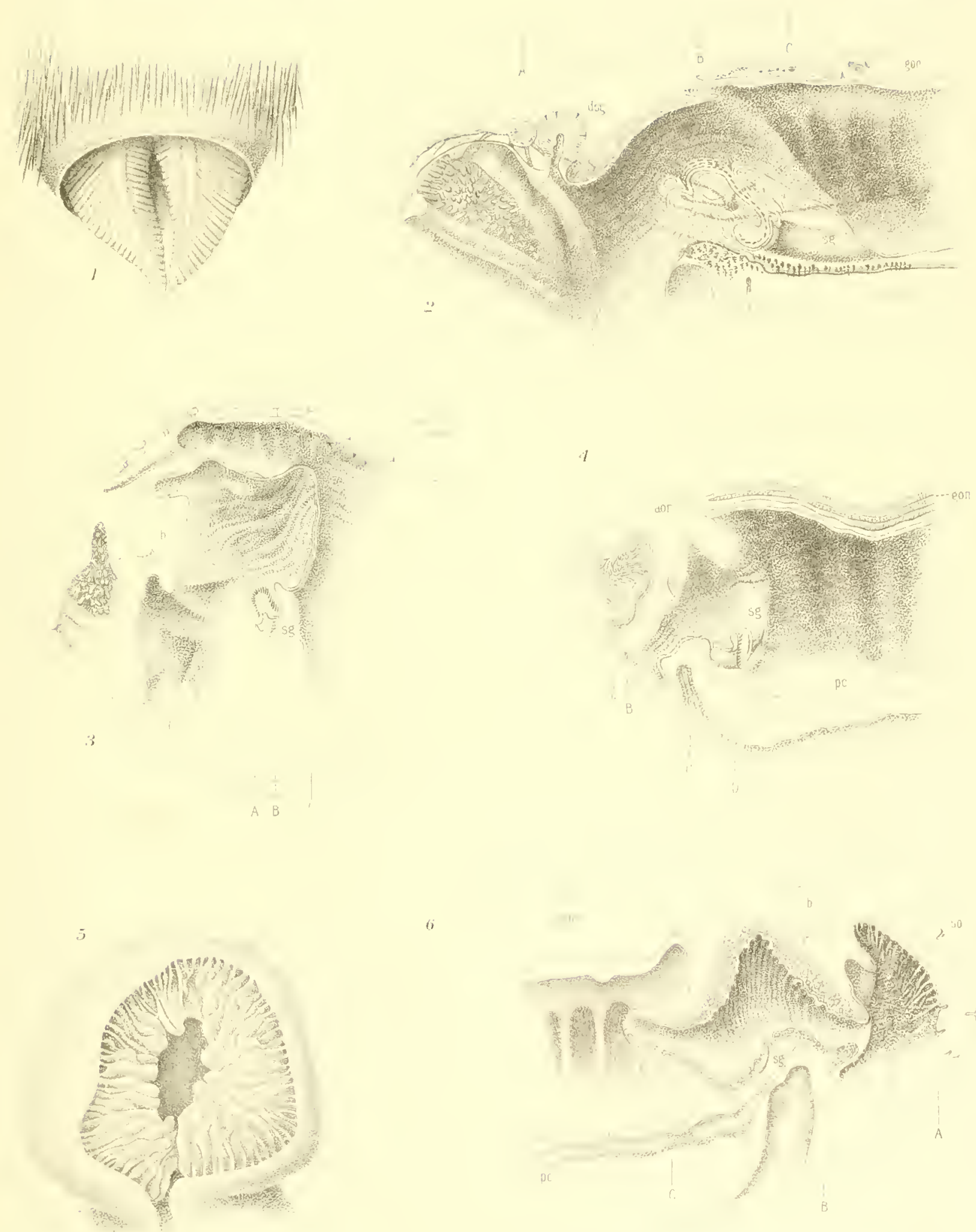

3 Heath deL 

PLATE 6. 
I'L.THE

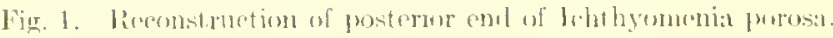

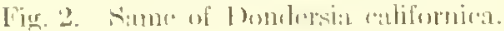

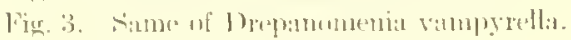

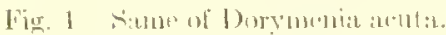

Fig. 5. Situs of : anterion and of lophomentia spiralis.

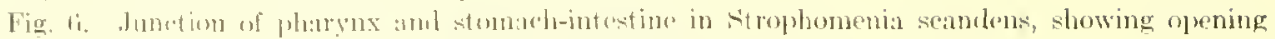
of the vent rat salivary gland and a purtion of the labio-buecal system.

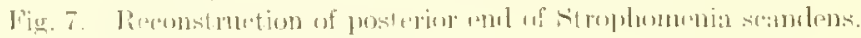

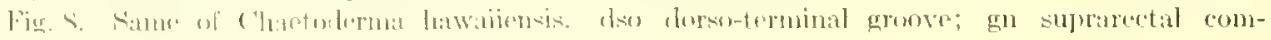

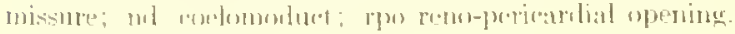



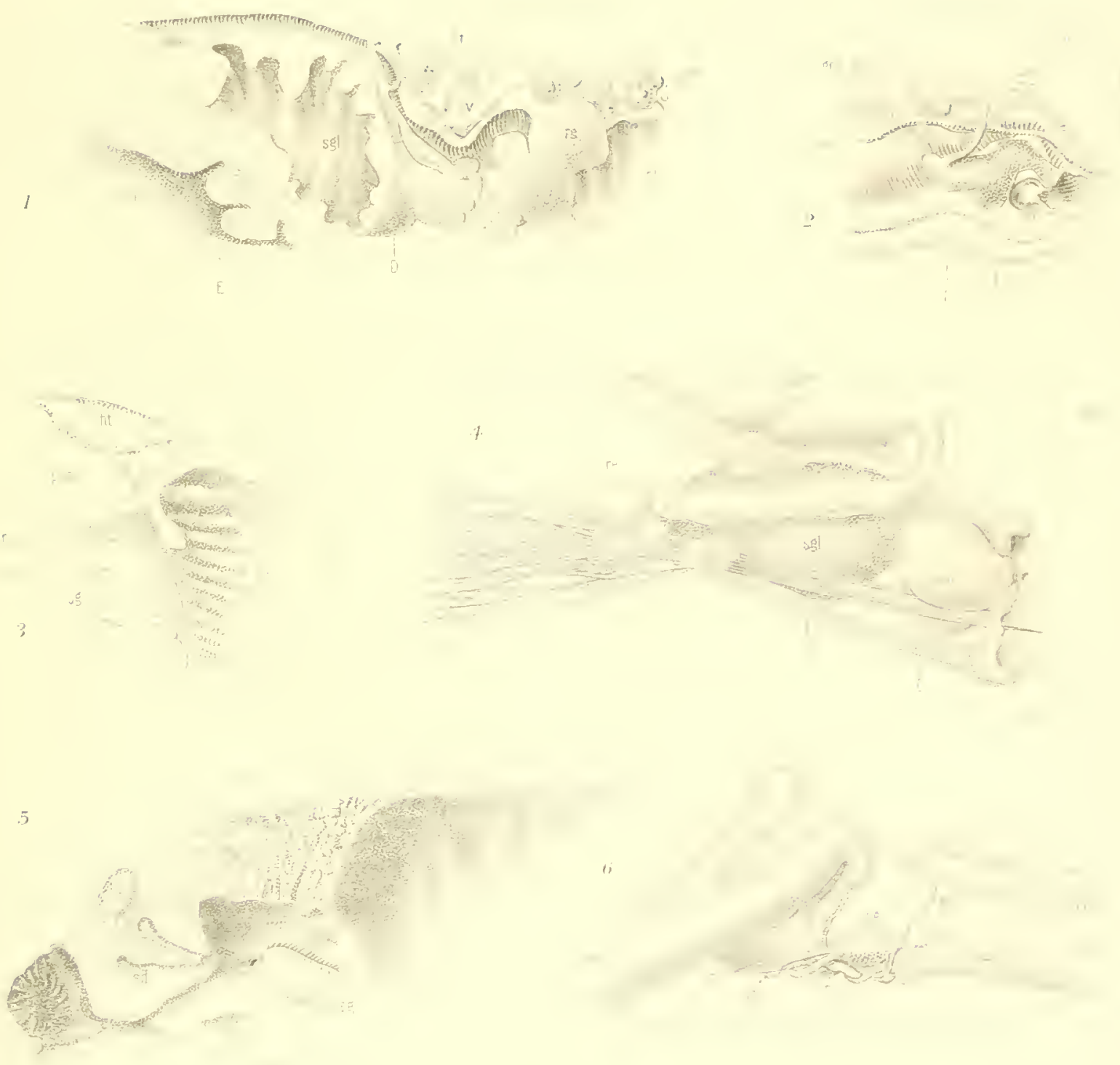

7
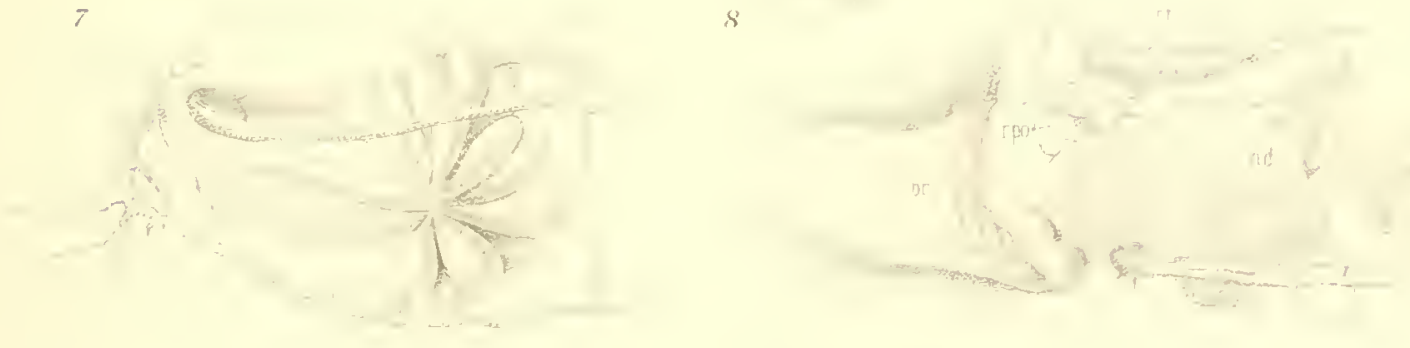
. 
PLATE 7. 
L'I ATE 7.

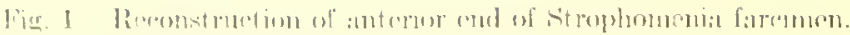

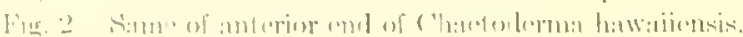

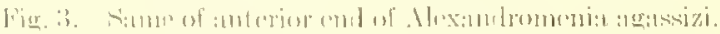

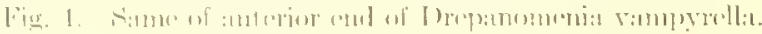

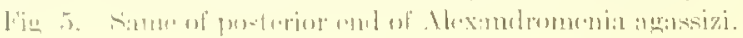



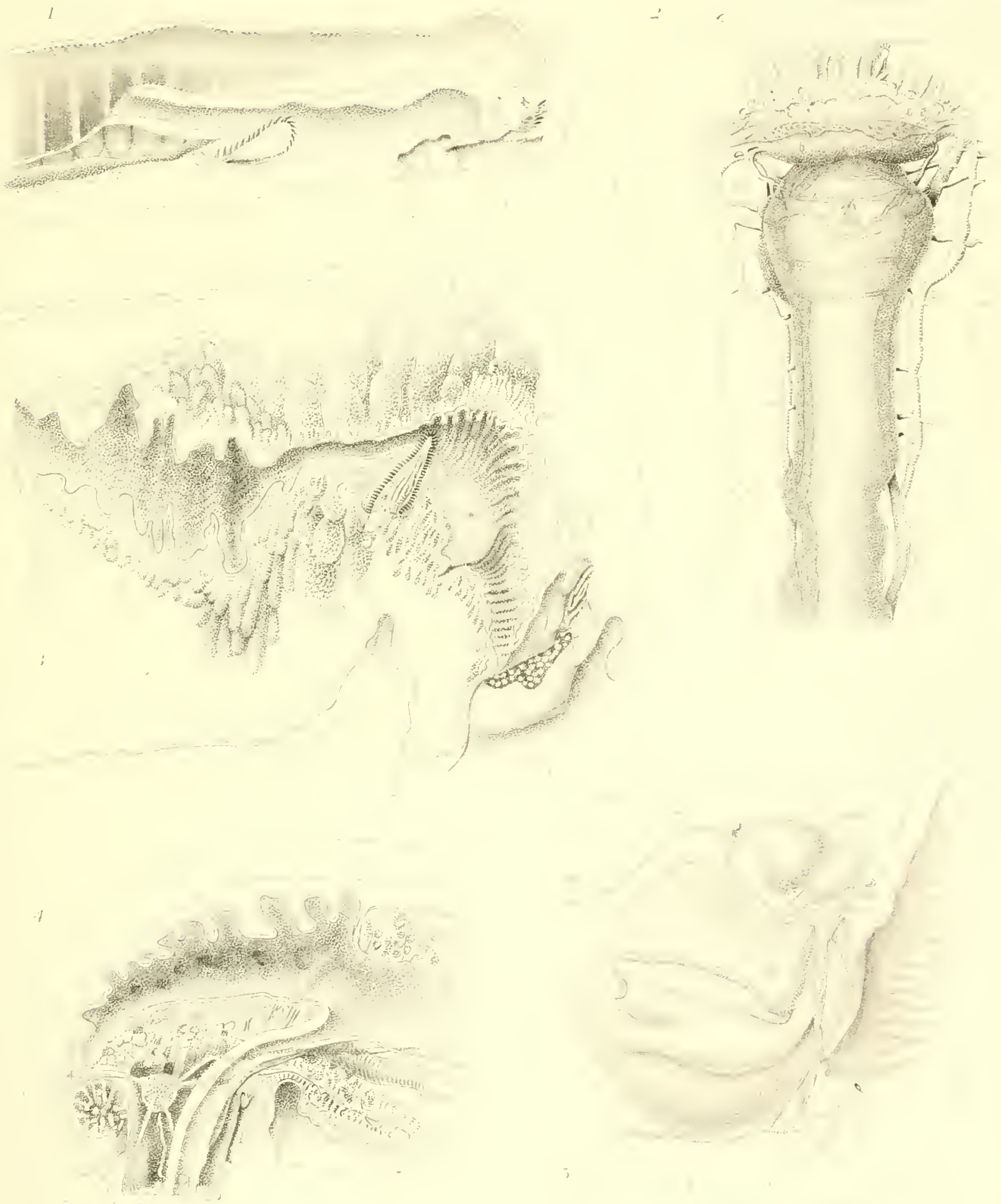


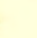


PLATE 8. 
PIATES

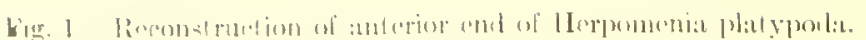

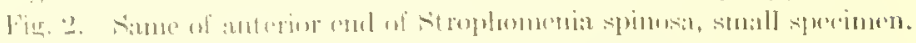

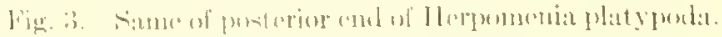

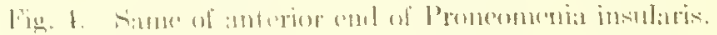

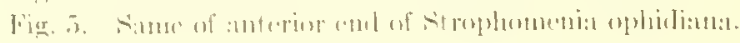

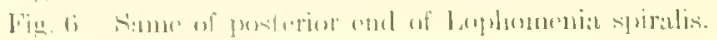



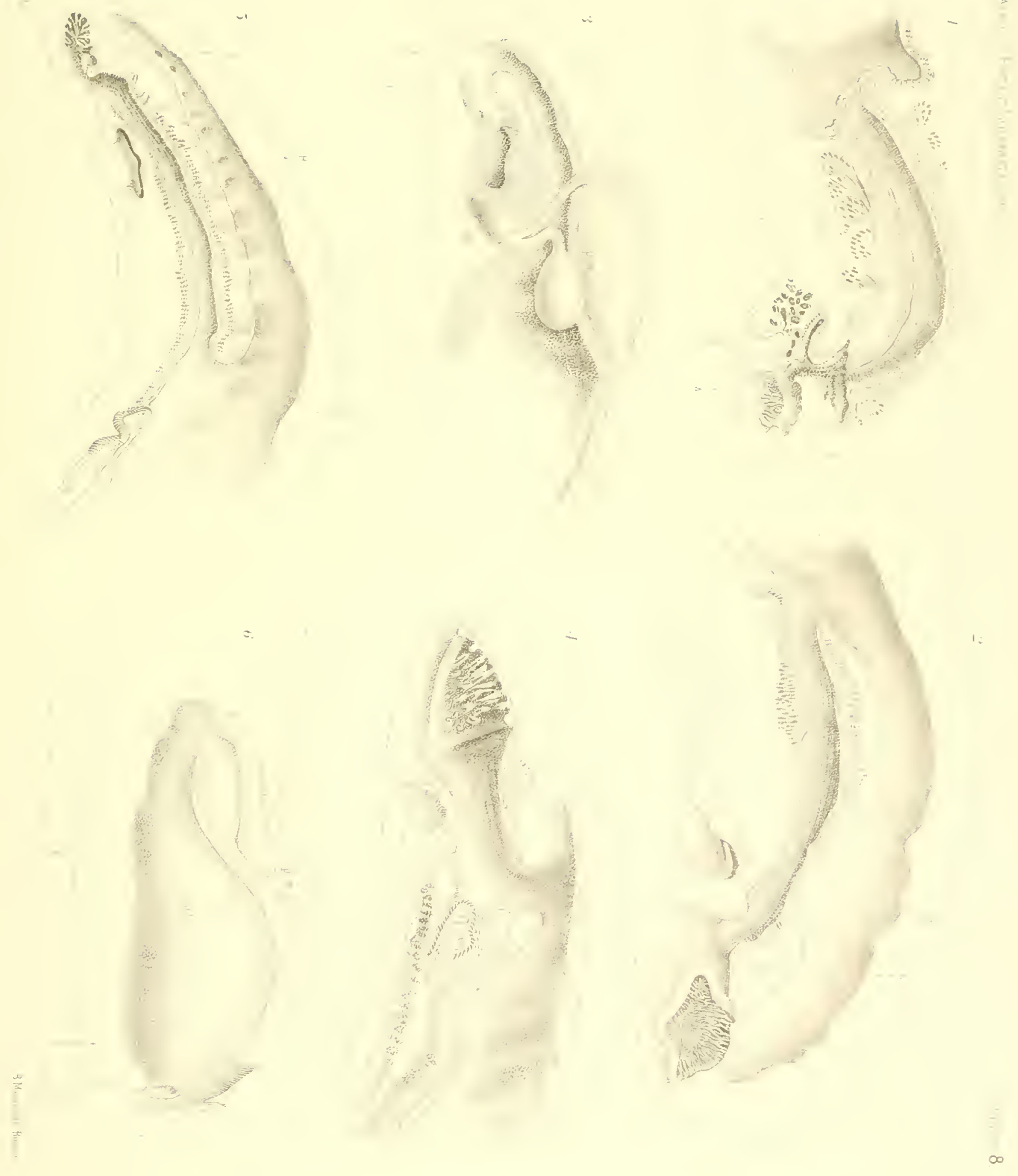


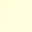


PLATE 9. 
PLAT'

lieconstruetion of the posterior end of the hody from transverse sections.

Yig. 1. Strophomenia ophicliama.

Fig. 2. Derymenia acuta.

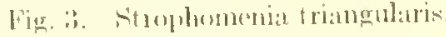

Fie. 4. Strophomenia spinosit.

Fig. 5. Liphenentia spiralis. 

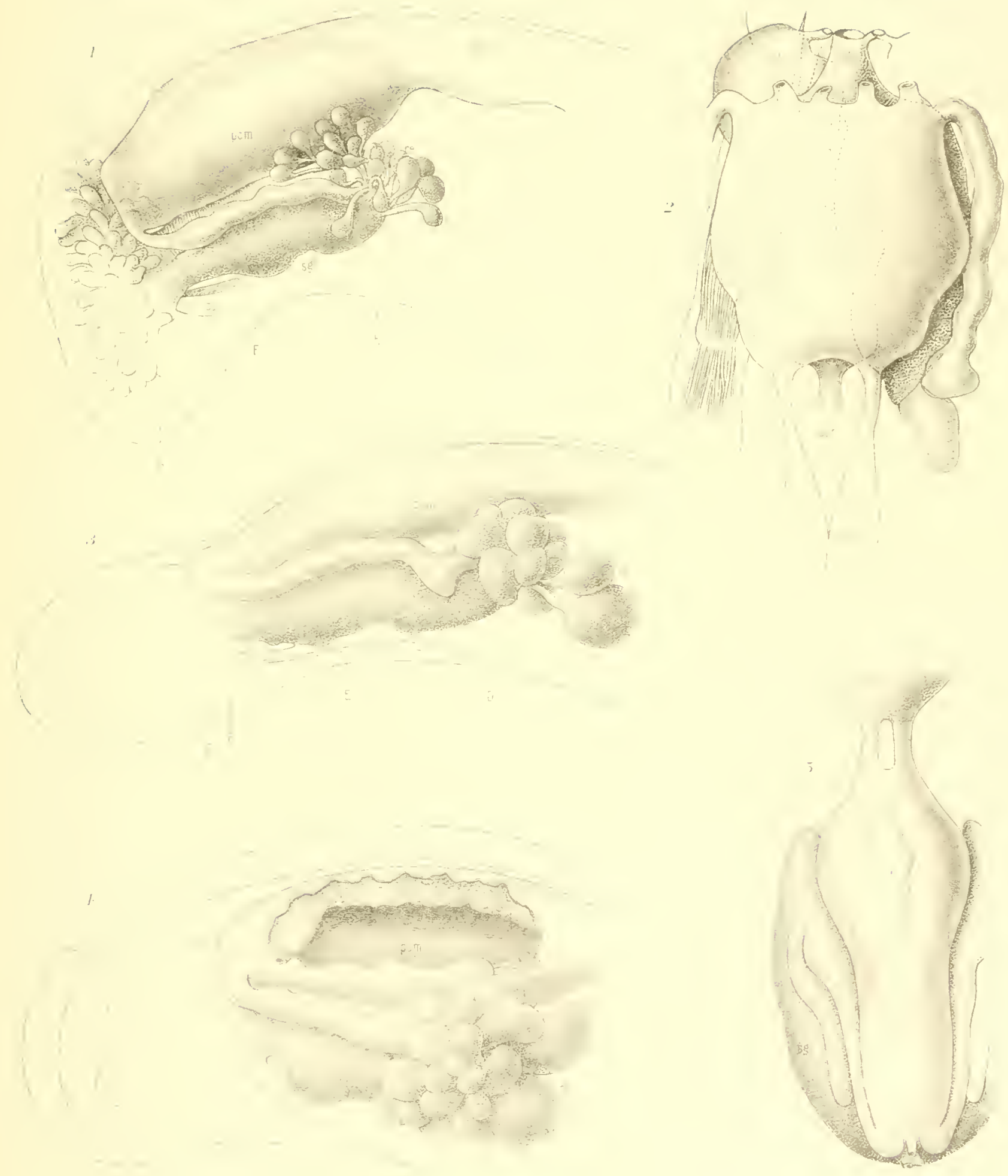

PLATE 10. 
PL.1TE 10.

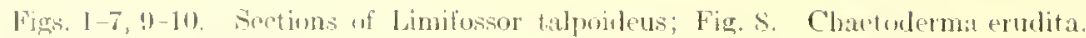

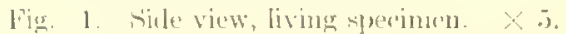

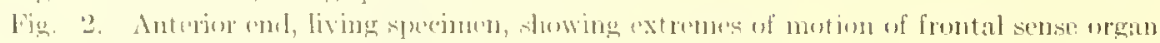

lige. :3. Lateral vinw of organs of pesterior ent of bouly.

Fin. t. Fimu of organs in anterion part of berly.

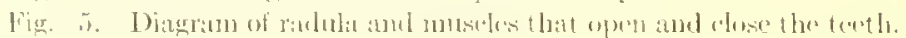

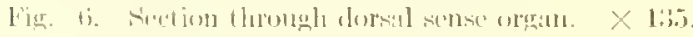

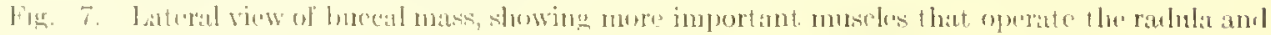
11 s.

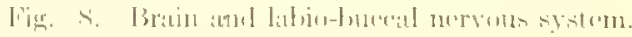

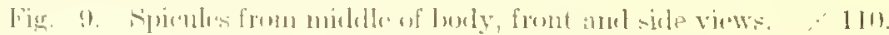

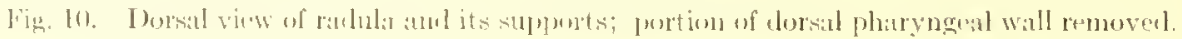



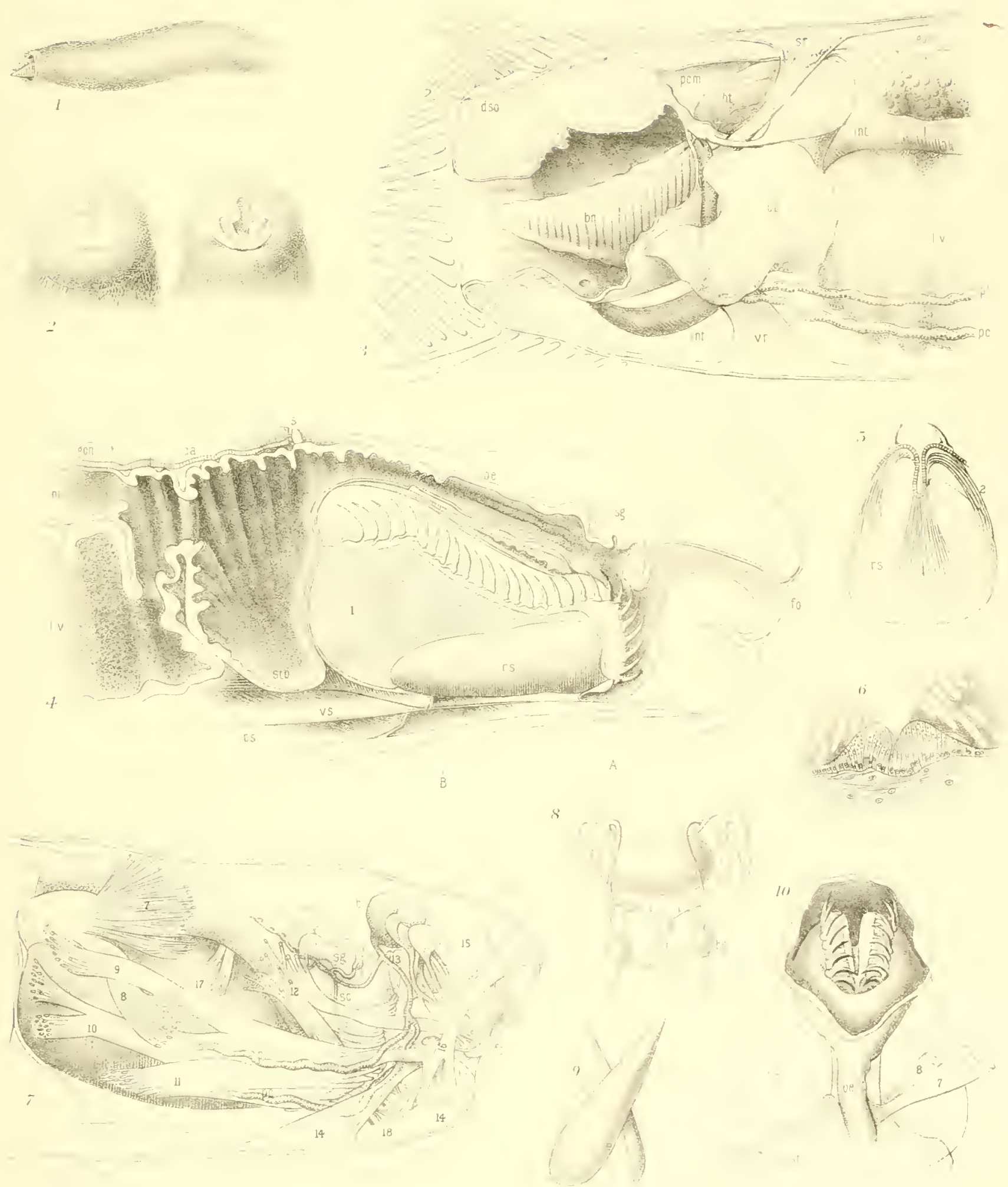

PLATE 11. 
I'L.1TE: 11 .

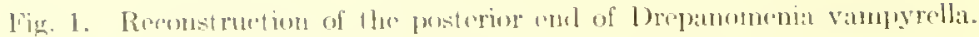

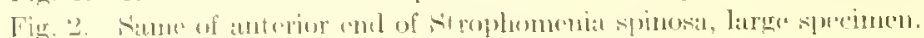

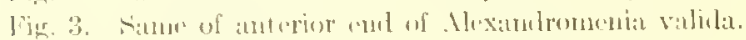

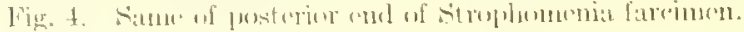

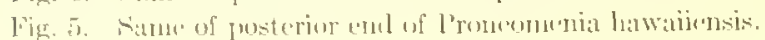



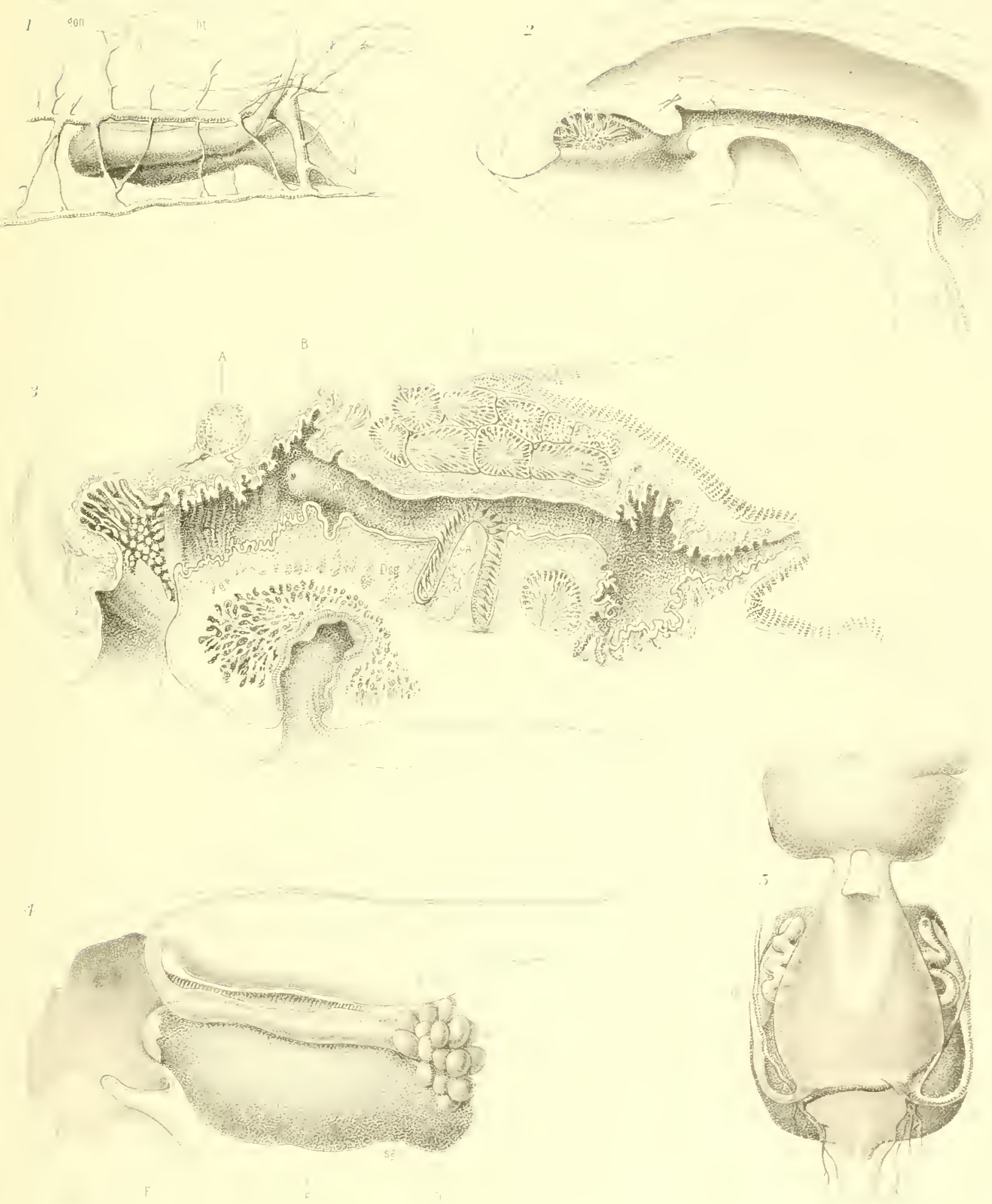
I'LATE 12.

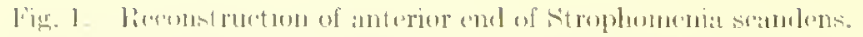

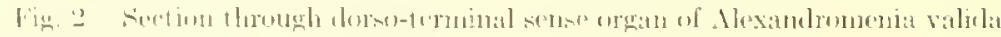

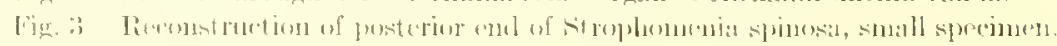

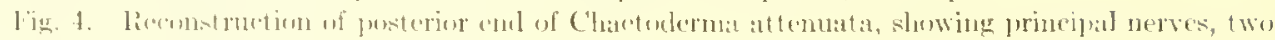
(1,rn) prassing into the gill.

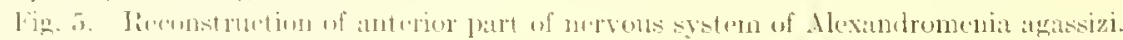

fing. 6. Sinne of pusterion cont. 

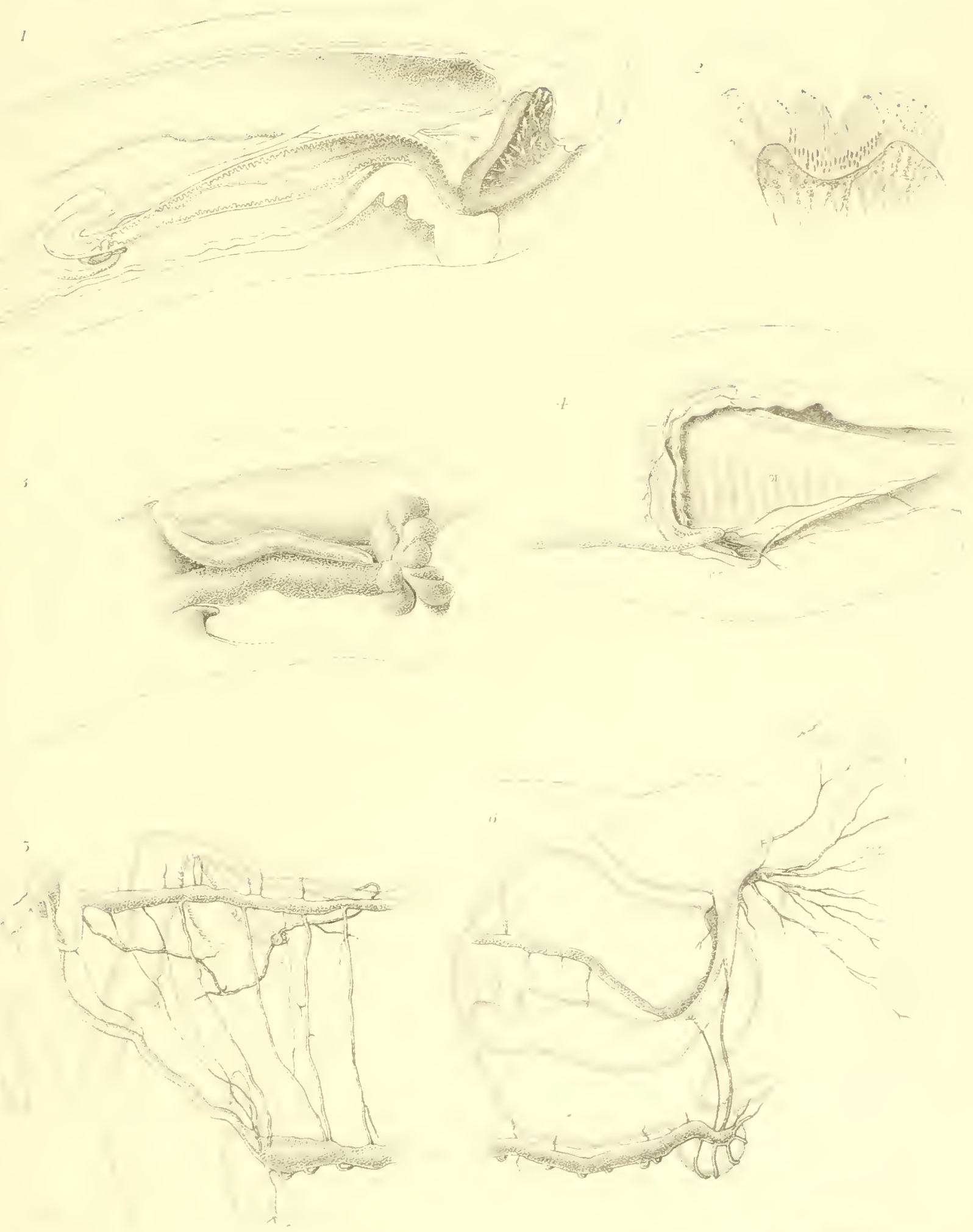
PLATE 13. 
PLATH: 13.

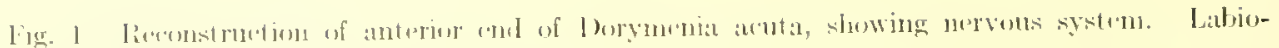
humenal system hearily shaterl.

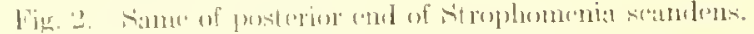

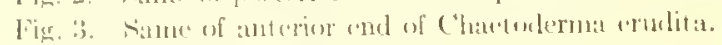

Fig. I. Same of pusterior enul of I'romemenia latwailensis. 


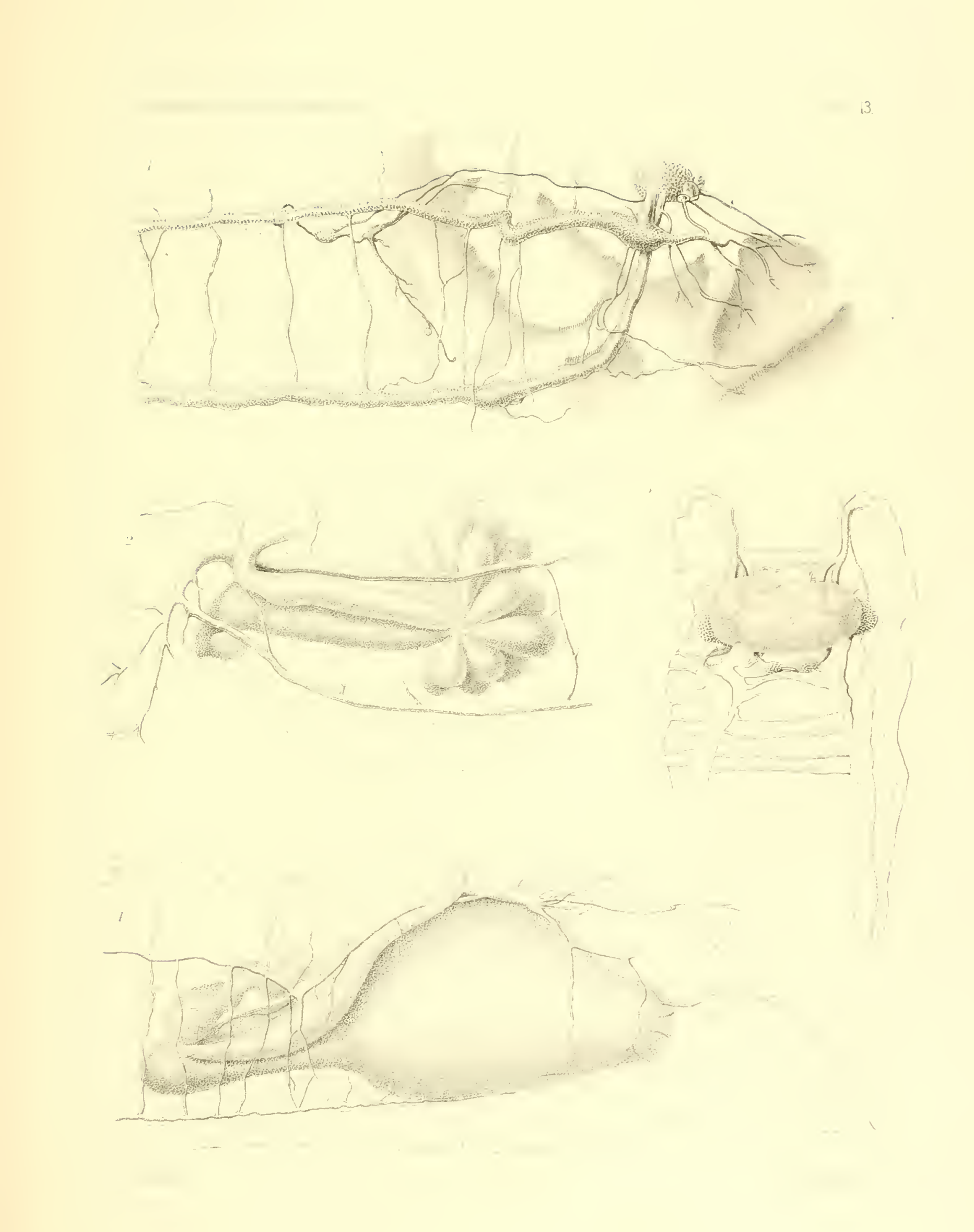



PLATE 14. 
I'LATE III

Crose sertions of l'romemenial hatwitiensis, $\times 33$.

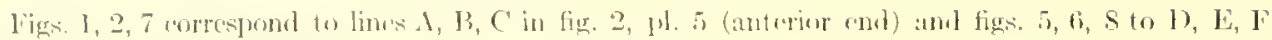

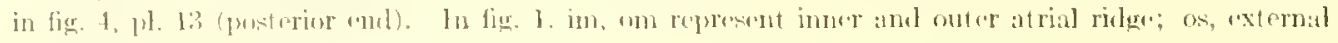
sensory tinlue.

lig :3. Sirting through millthe of horly.

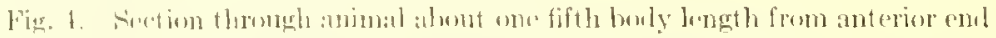

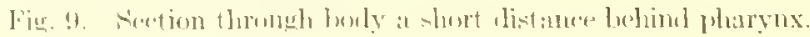




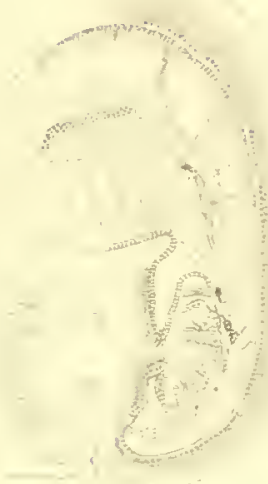

4

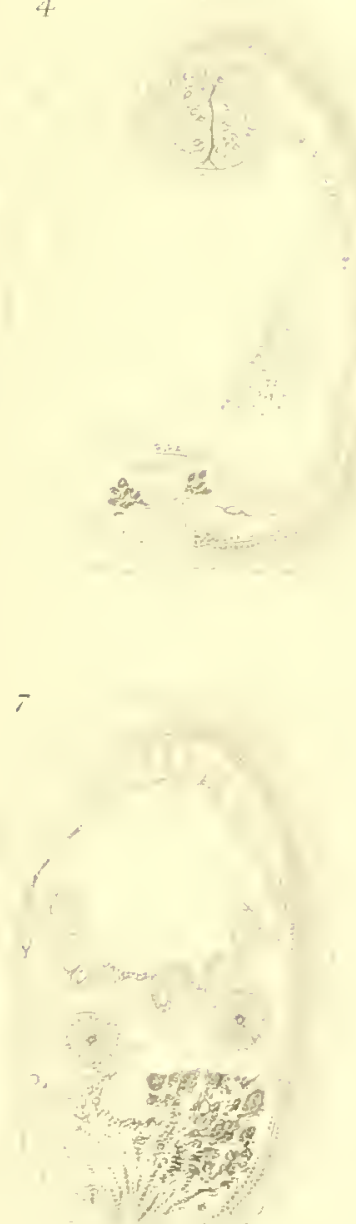

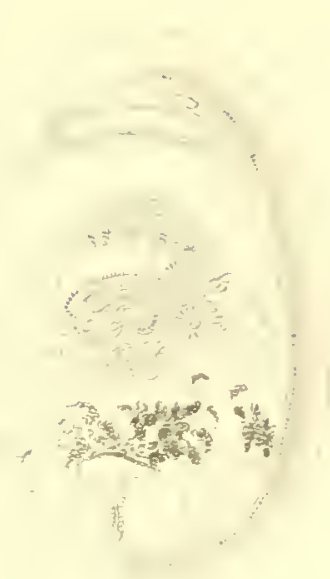

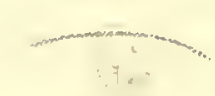

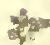
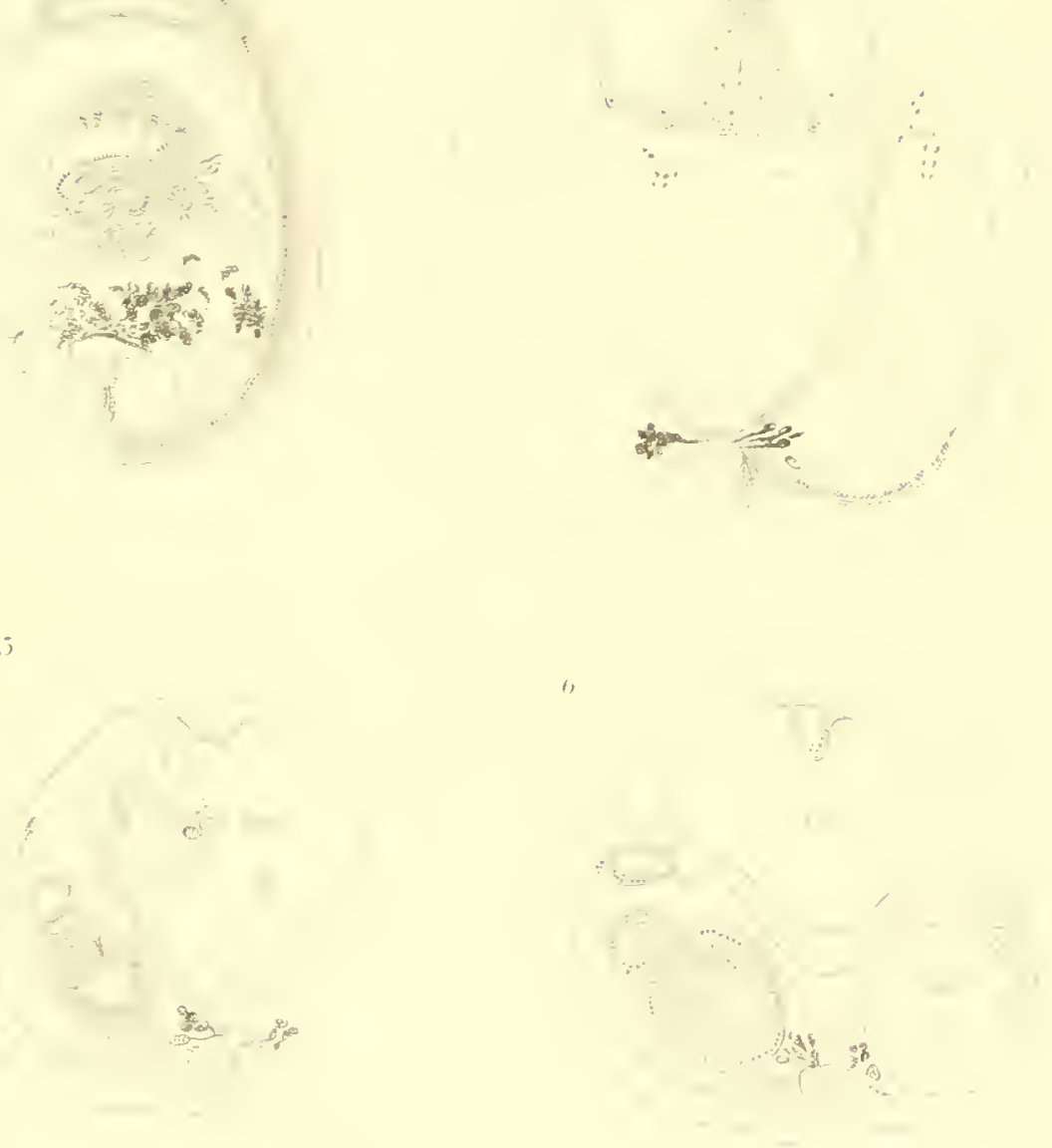

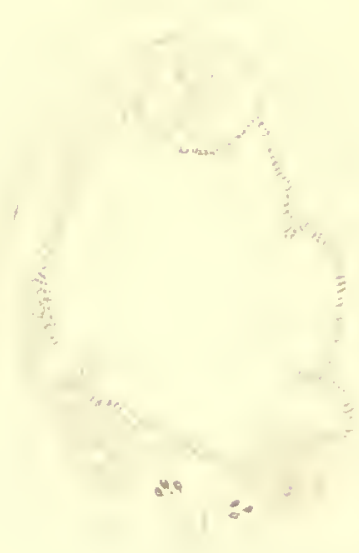


PLATE 15.

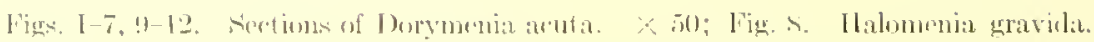

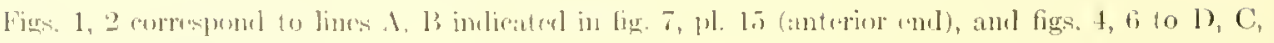

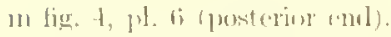

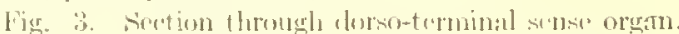

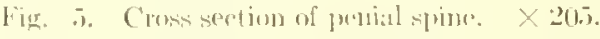

Fir. 7. Langitudinat seretion of interior end of borly.

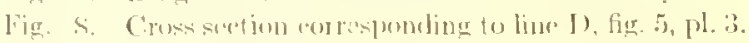

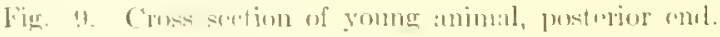

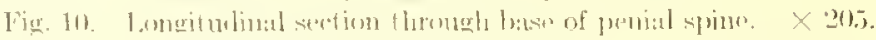

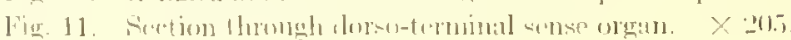

Fig. 12. Sirtion throumh atrial carity. 
I

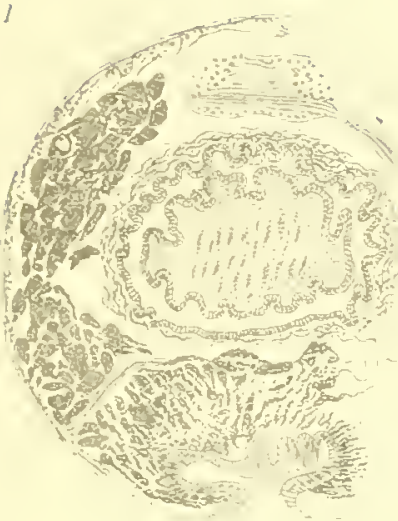

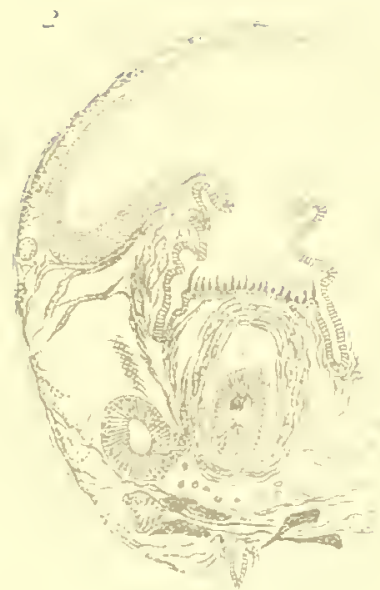

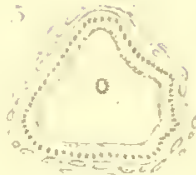

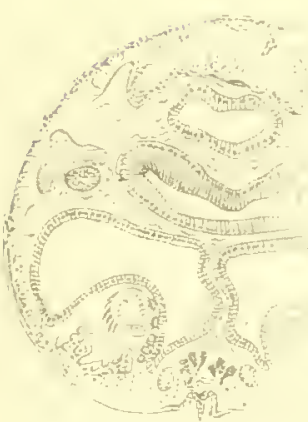
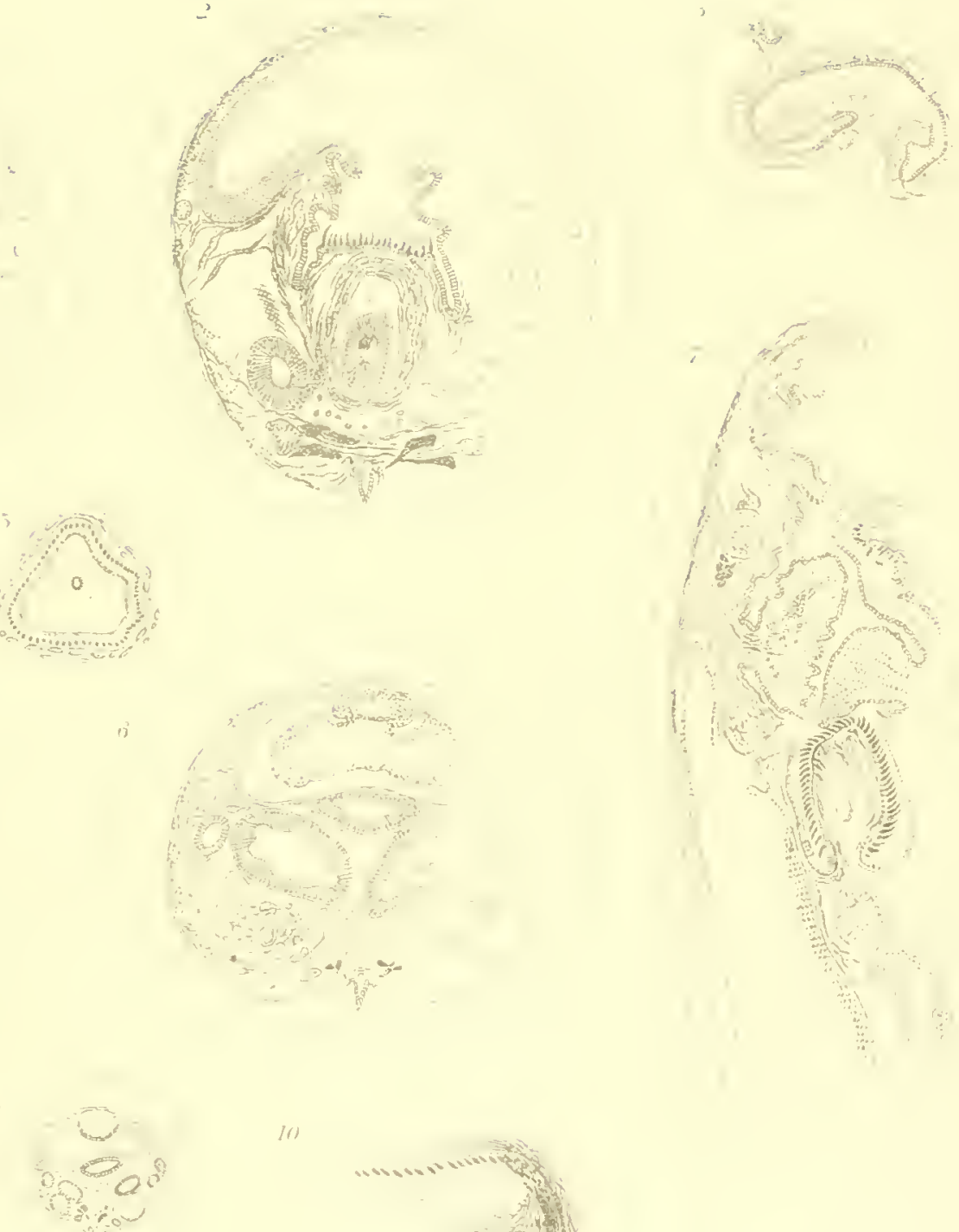

8

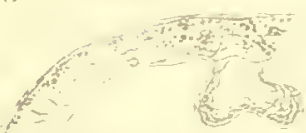

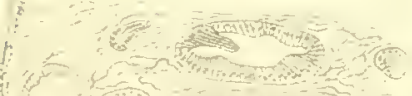

+40 b

Non

$2=0$
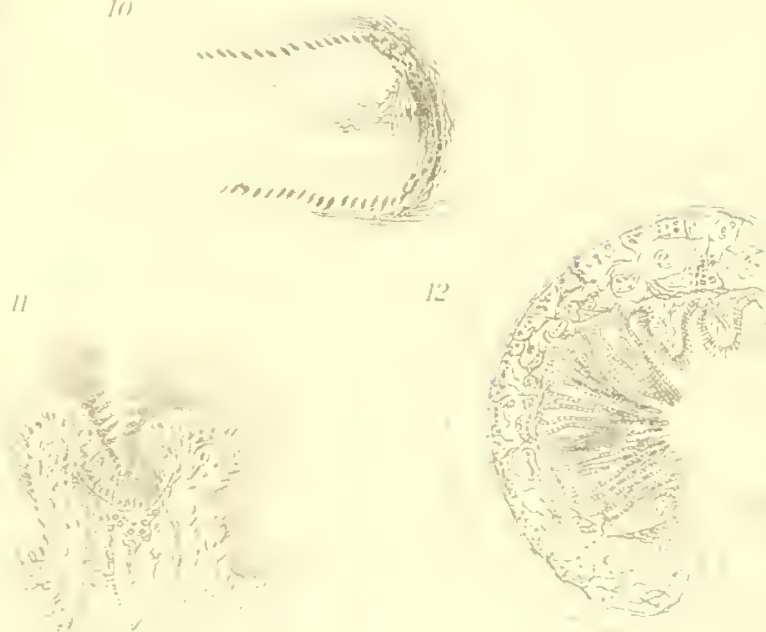

PLATE 16 
PlATE It

Cross sections ol sirophomenia scandens. $\times 33$.

lig. 1. In region of brain.

lic. 2. Brhime pharynx.

line. is. In mistlle of busly.

lï. A. Througl pharyen opposite anterior pedal glamel outlet

lite. is. Through sominal remptachs.

Fige if Through mid sertion of enclomodurts

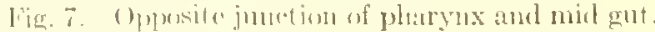

Fin.s. Throngh jumetion of andemenluets.

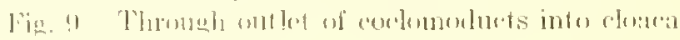




$$
\begin{aligned}
& 320 \\
& 90 \\
& 20
\end{aligned}
$$



PLATE 17. 
MATE 17.

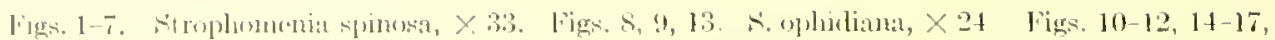
S. farrimen, $\because 33$.

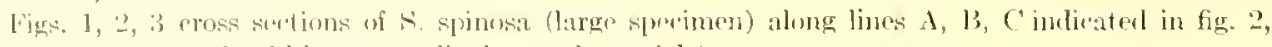

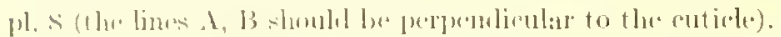

lig. 1. Cons suetion through randulat and salivary gland outlet, s. spinosat.

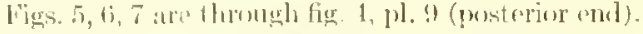

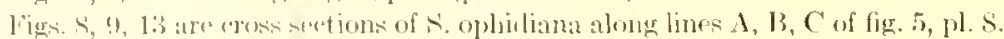

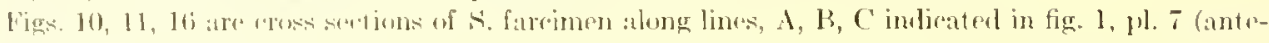
rior (and).

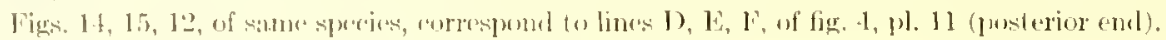

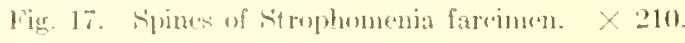



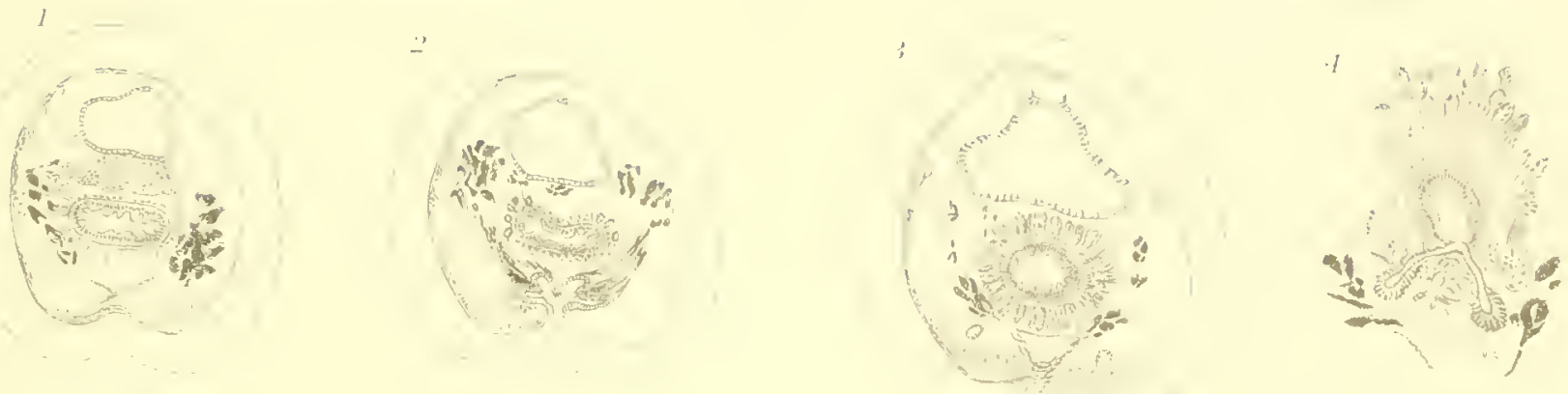

.5

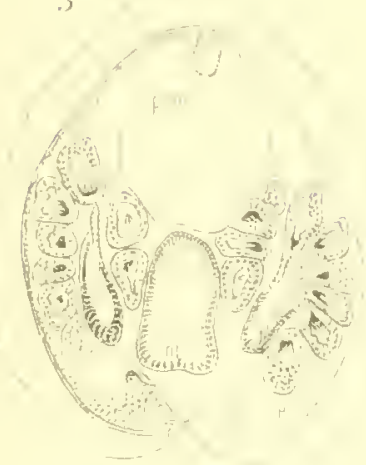

(i)
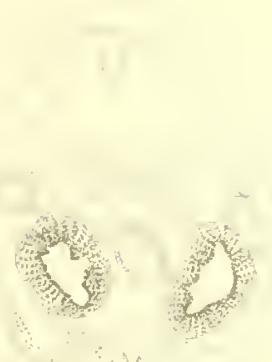

sis
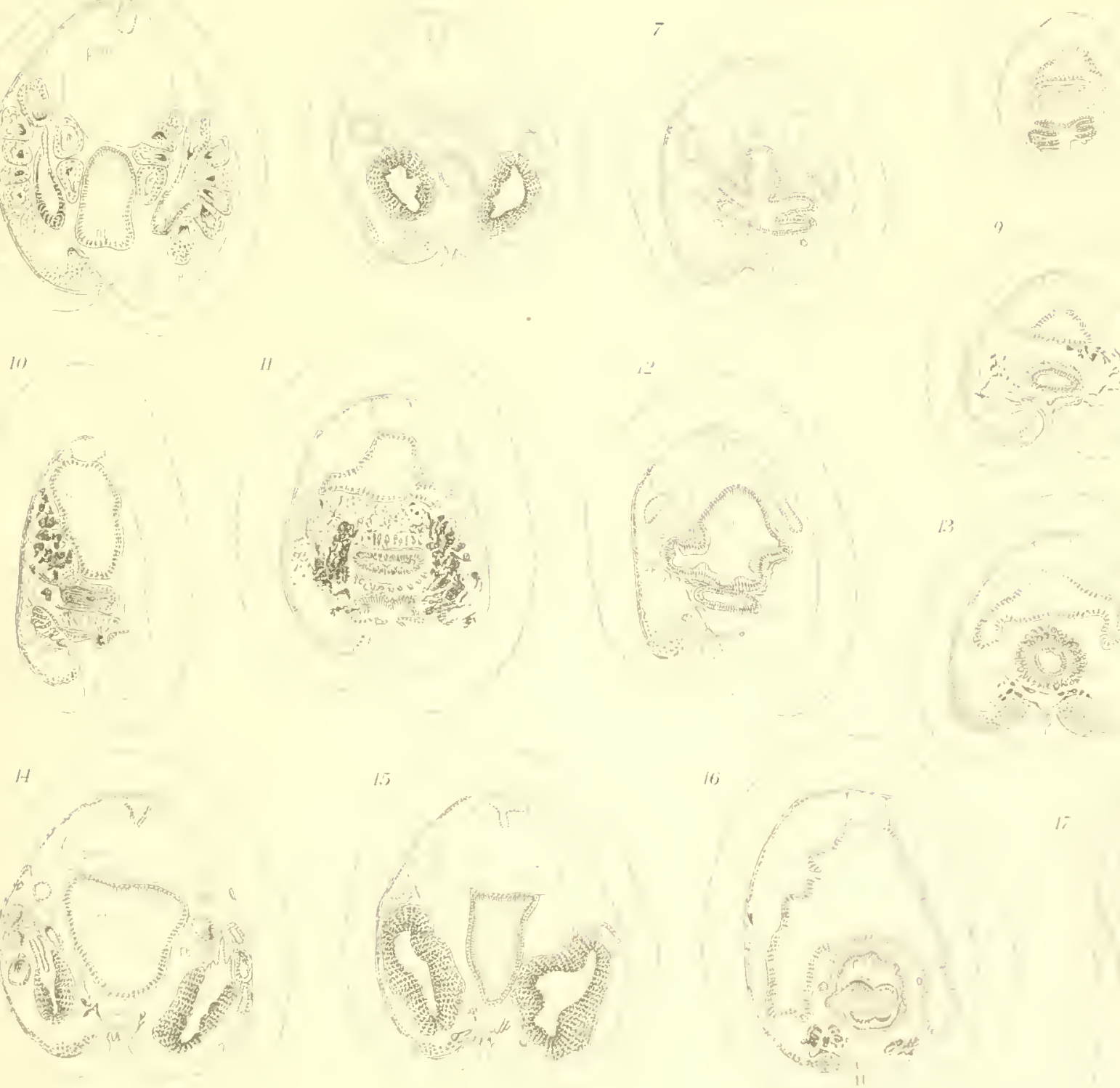

PLATE 13. 
PI. ITE IS

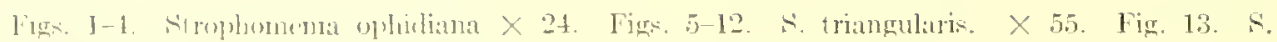
farrintert. $\times$ ii().

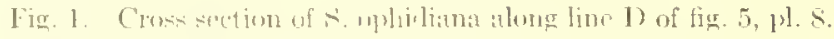

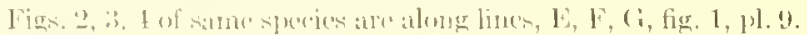

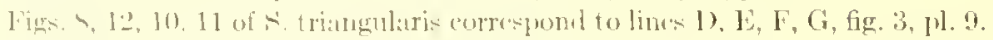

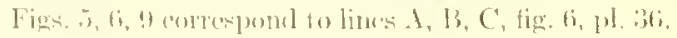

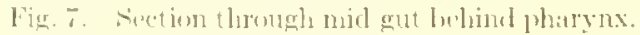

Fig. 13. Siretion through mil gut of s. farrinen in region of salivary glamls. 

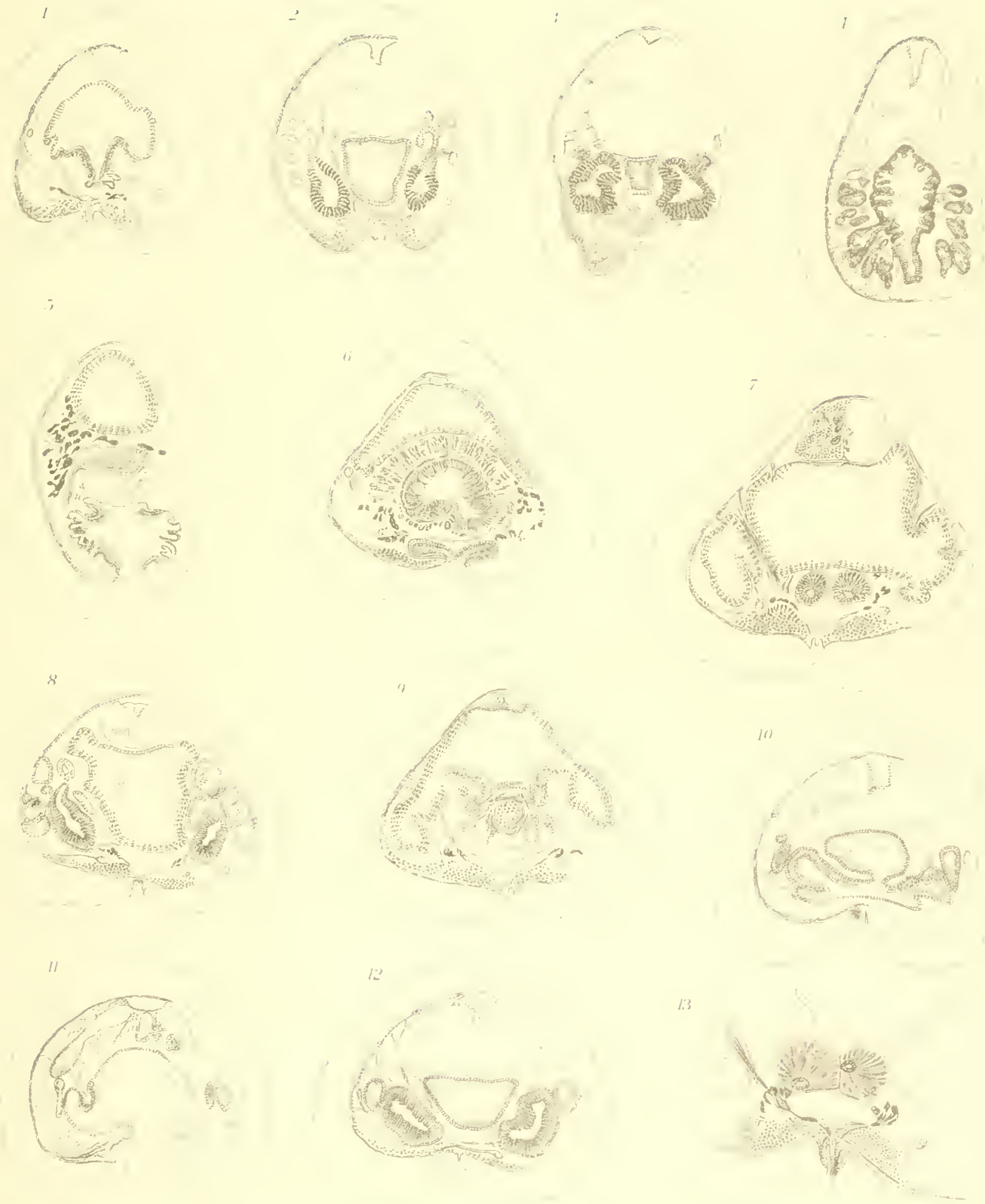

PLATE 19. 
J'LATL 19.

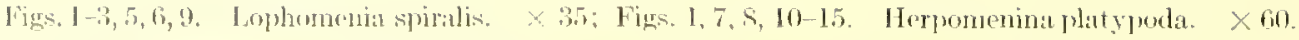

Figs. 1, "2, aross sect ions of mude "arved specinen of Laphomenia spiralis. $\times 15$.

Fig. 3. Pention bethind phlitryax.

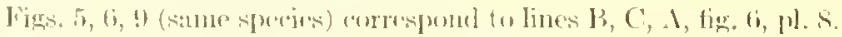

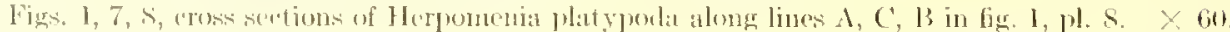

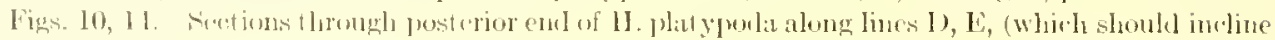
(o) Ieft) tig. 3, jol, s.

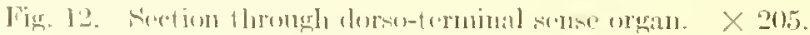

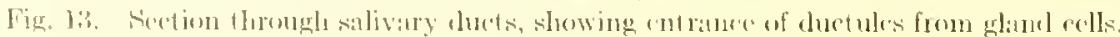

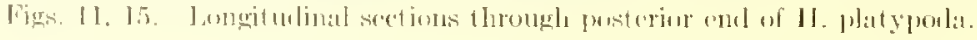




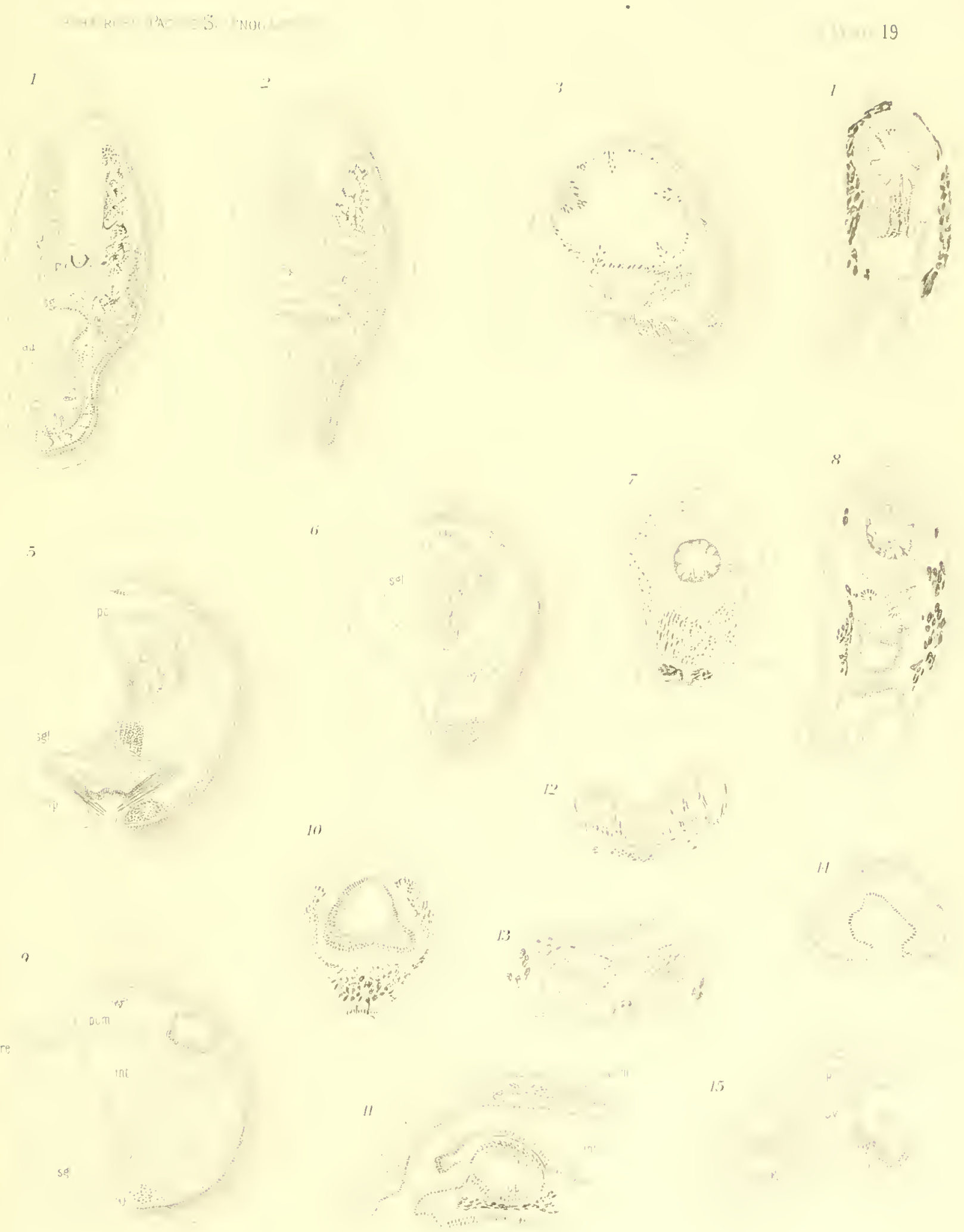


PLATE: 20.

Atexandrumenia agasiziz. $\times 25$.

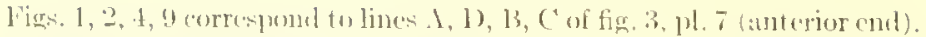

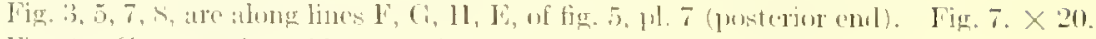
Fig. li. Cross section of brart at junetion of its two livisions. 

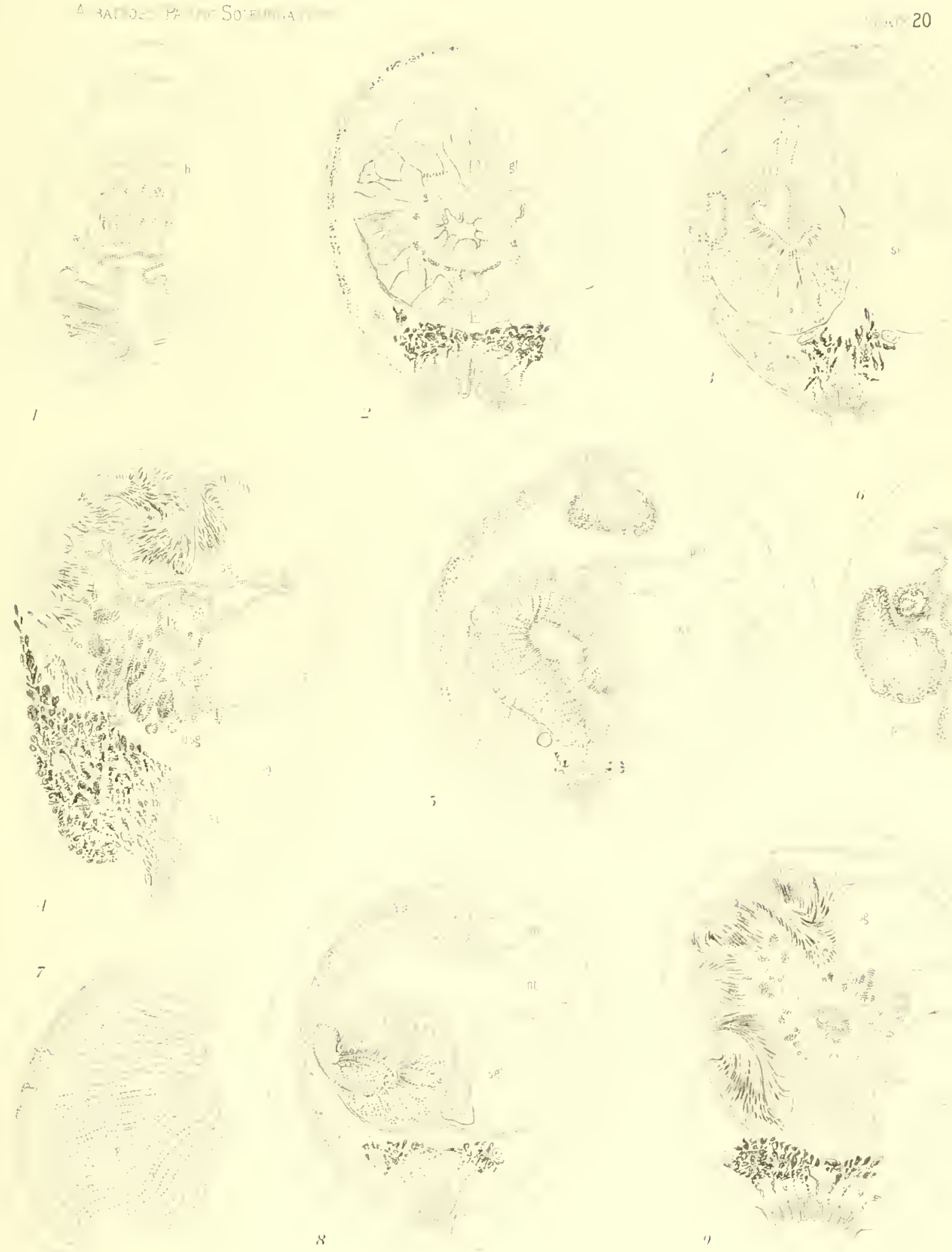
PLATE 21 
I'LATE 21.

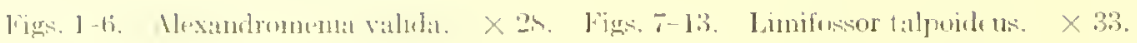

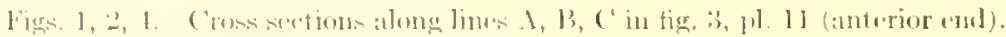

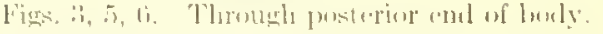

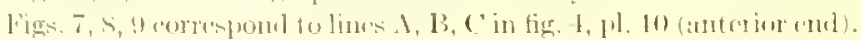

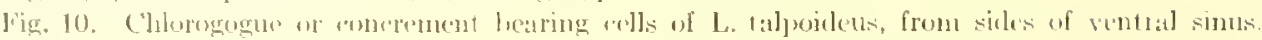
$\times$ inis.

Fig. 11. Sicetion through train.

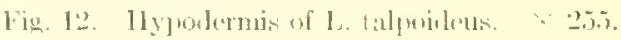

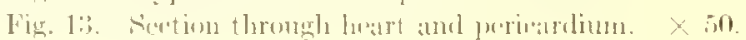



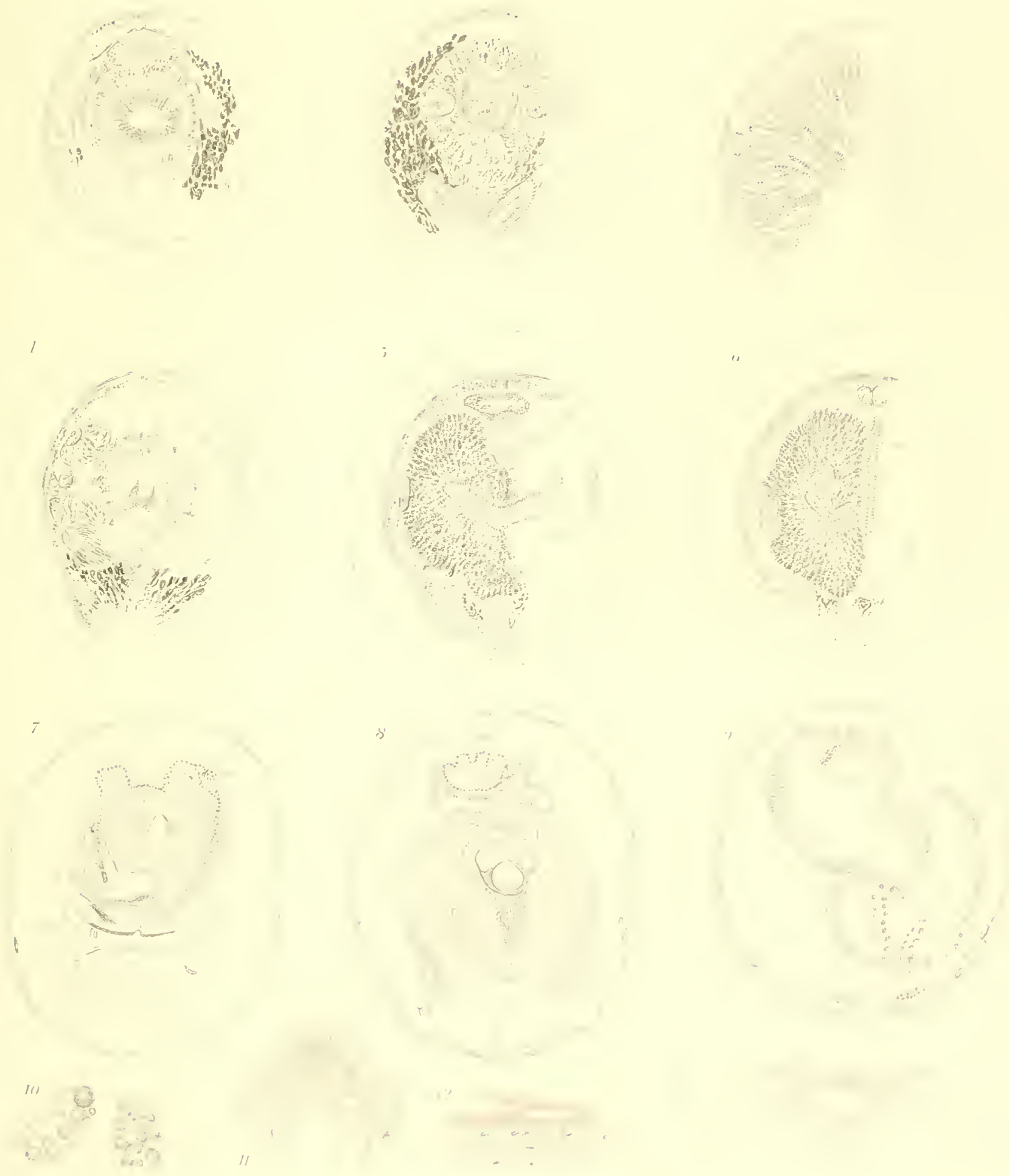

s. 


$$
\text { - }
$$


PLATE 22. 
PLATE 22.

Cross sections of Ilalomenia gravida. $\times 55$.

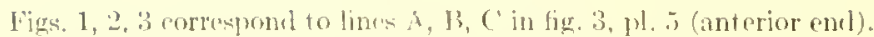

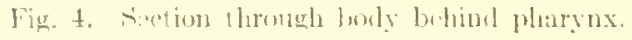

Fig. 5. Sidixary gland lohules opening into main dowt.

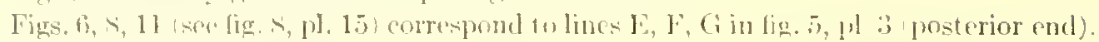

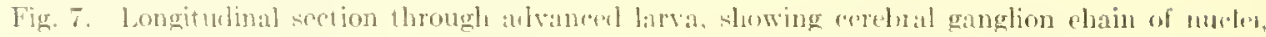
stomodacum, st, amb carly stagt in the tevelommont of the anterior pulal gland and outlet, $f$.

Fig. 9. Fintion thronglt anterior slivision of heart.

Fir. 10. Siention threngh jumetion of two divisions of heart.

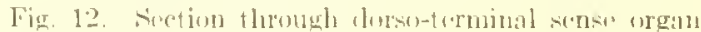

Fige 1:3 spines from mildle of borly: $\times 340$ 

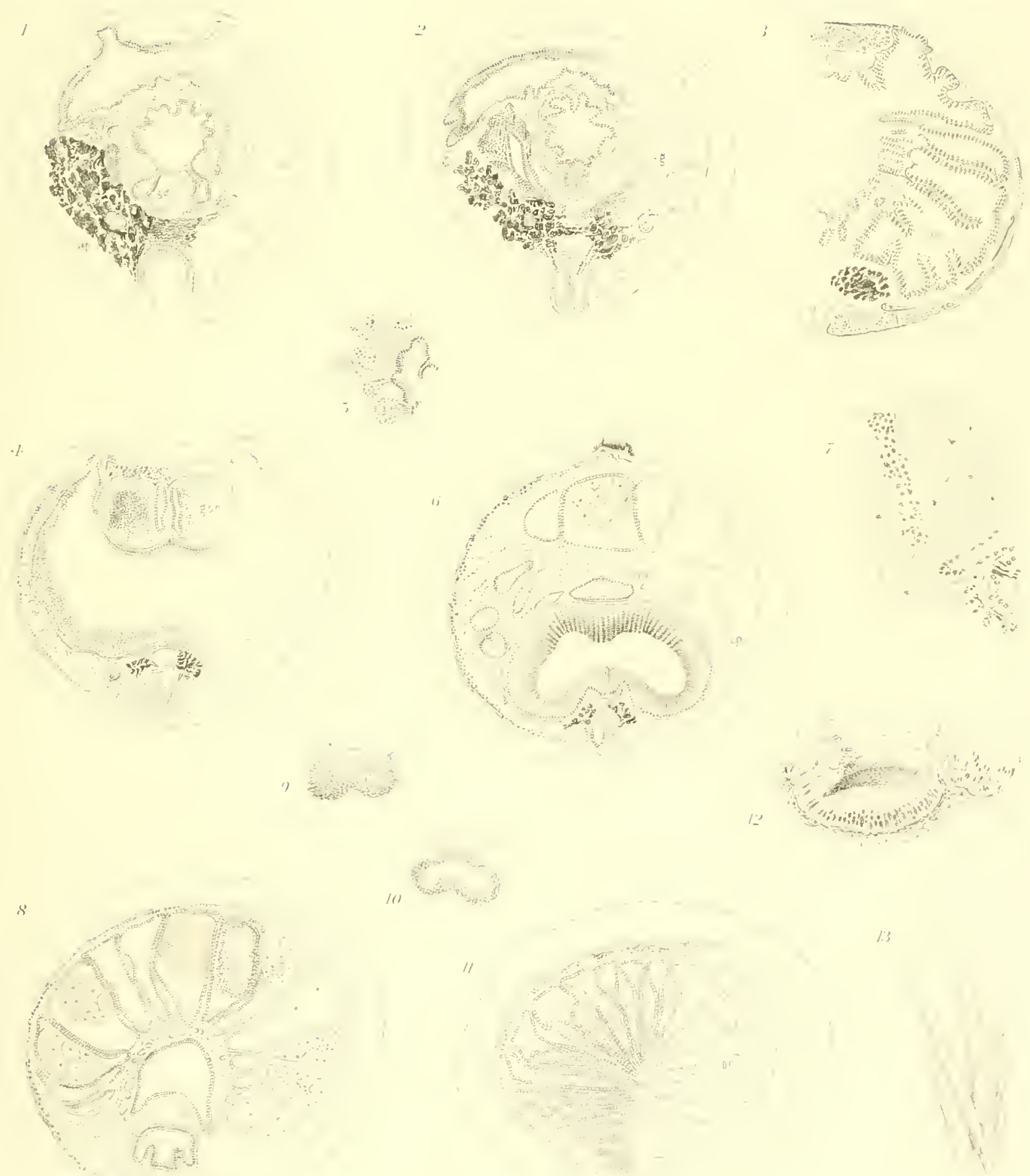


$$
\text { • }
$$


PLATE 23. 


\section{PLATE :}

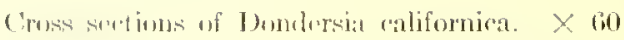

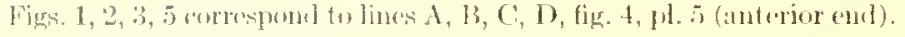

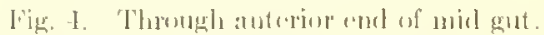

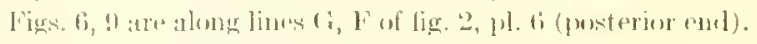

Irig. 7. Thomgh midile of bouly.

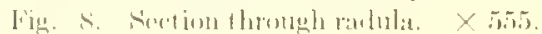




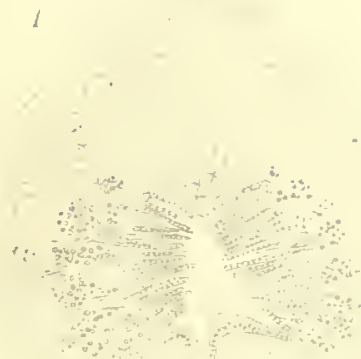

3
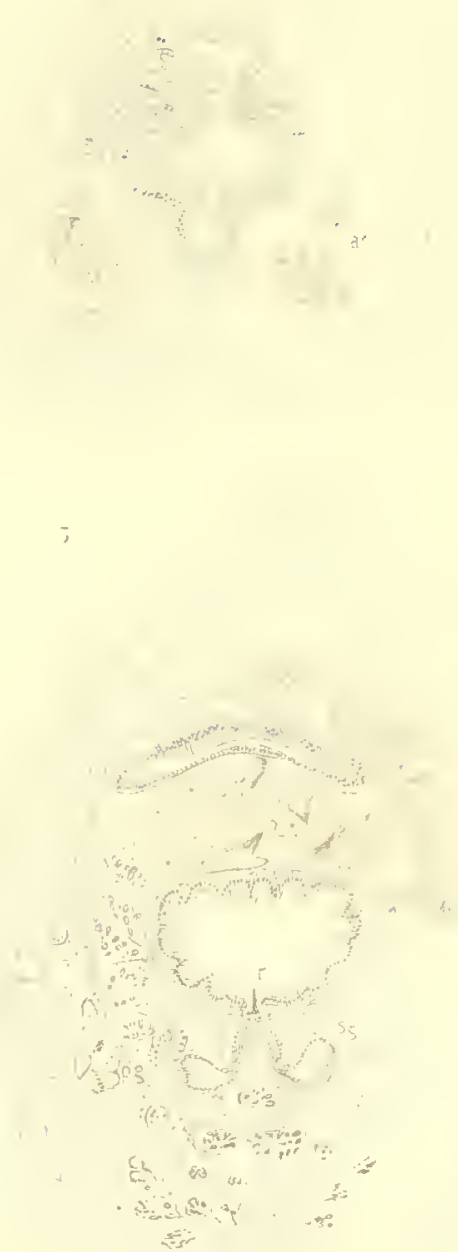

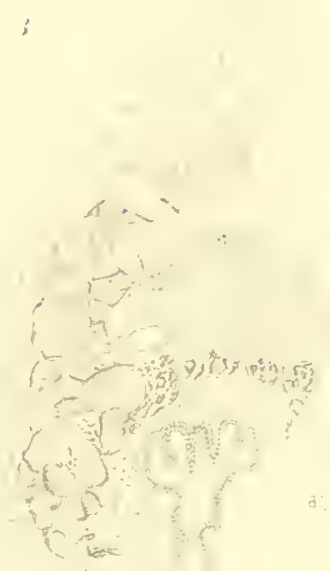

;

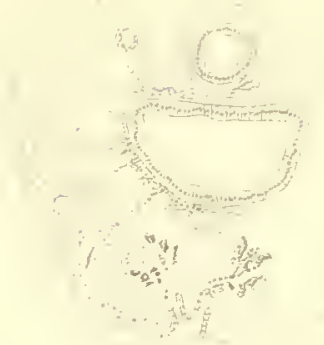

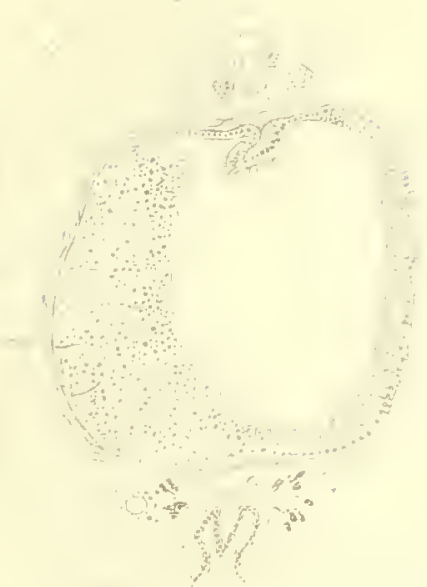
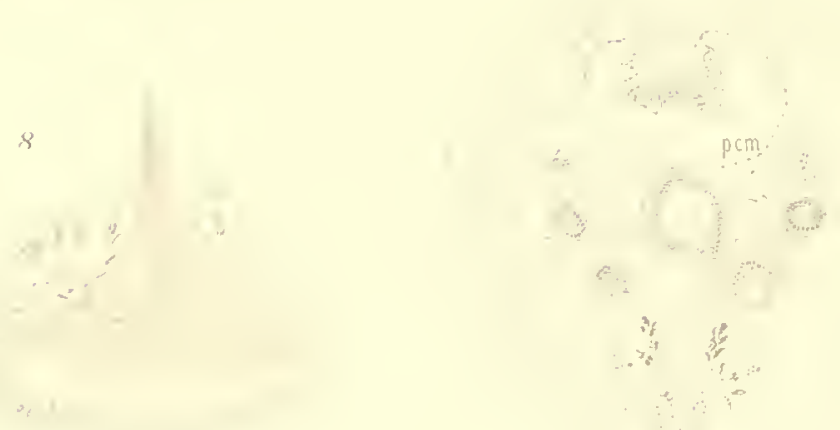
PLATE 24. 
I'ATE 24.

Figs. 1-5, 11. Seetions of Iehthyomenia poros:a. $\times 55$. Fig. 6-10, 12-14. Strophomenia regularis. $\times 55$

Figs, 1, 4, 11 of 1. porosa, conrespond to lines 13, C, A, fig, 6, pl. 5.

Figs. 2, 5 arre tlemg the lines li, D, fig. 1, 11. 6 (pusterior ent).

Fig. :3. Section theselgh midhlle of benly.

Figs, 6, \&, 9, 10, of, regularis, are along the lines, C, D, B, A in fig. 8, pl. 26 (in fig. B rearl el in Hiter of (t).

Fig. 7. Sertion of enticle and hypordermis of s. regularis. $\times 205$.

Fig. 12. Feetion thromgl one sense organ of anterior end of I. porosa $\times 555$.

Fin. 13. Sertion througl one seminal reephate and several stalks of S. regularis. $\times 255$.

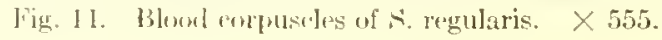


$x_{1} x^{2}$

-1)

$5-2 x^{3}=$

res $=$

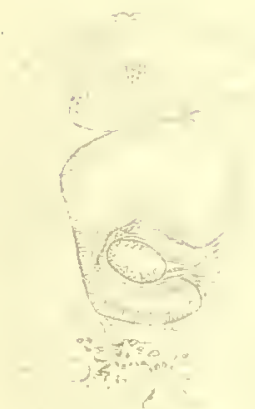

$x$

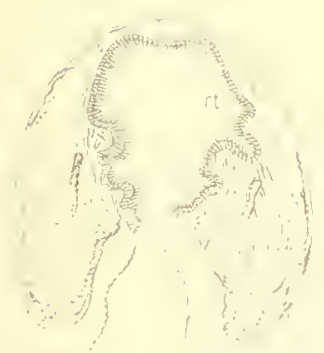

II

$x^{2}$
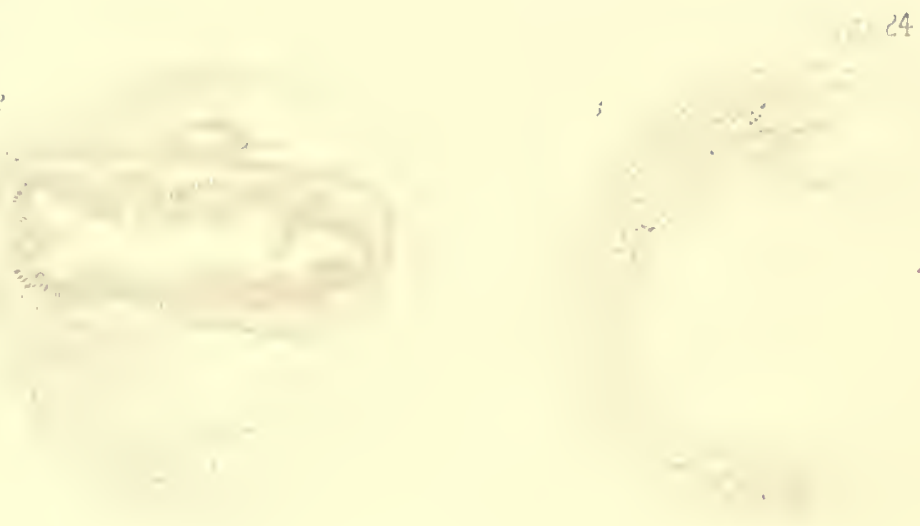

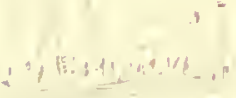

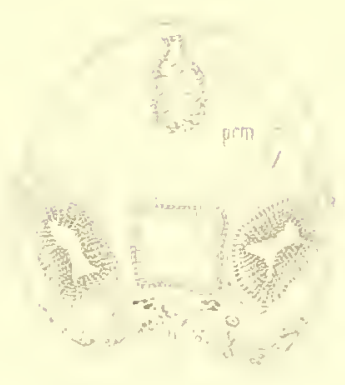

III

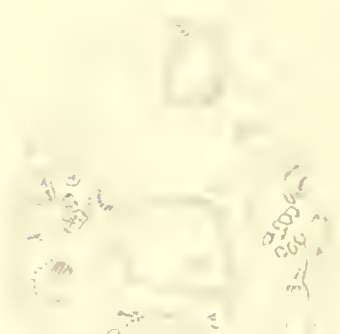

$1 \%$
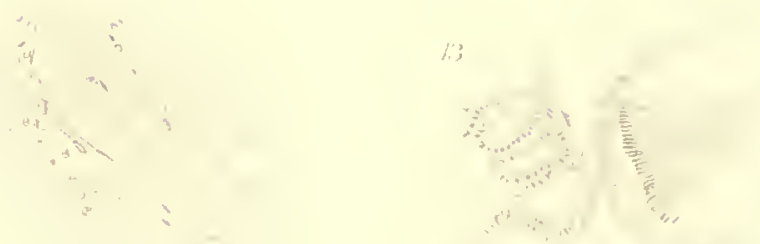


\section{,}


PLATE 25. 
PLATE 25.

Gectionsof Chactolema attenuata. $\times 33$.

Fig. 1. Siection through brain.

Fig, 2. Section through rakhla.

Fig. 3. Seretion through junetion of stomich and intestine.

Iig. 4. Siretion through suprareetal commissure.

Fig. 5. Seretion throngh ontlet of roetombluet (pores omitted in figure).

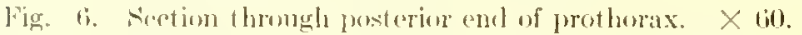

Fig. 7. Ilypulurnis, showing gland cells and attached fitres. $\times 555$.

Fig. s. sicetion through hatert.

Tigs. !) 10. Two sucerswive seetions thrugh the subradular ganglion and connectives. $\times 135$. 



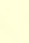


PLATE 26 
PLATE 20.

lïgs. 1-7. Chatroulerma argentea. $\times 33$; Fig. S. Sitrophemenia regularis. Fig. 9. Alexandromminia agassizi.

lïgr. 1. Through brain region.

lïg. 2. Through raulula.

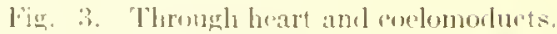

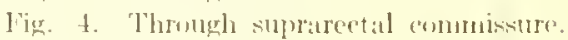

Fig. 5. Through region of outlet of conlomoducts.

lige. li. Througla pesteriour and of prothorax.

Fig. 7. Through junction of pharynx and stomarle.

lig. s. Reconstruction of posterior end of strophomenia regularis.

lige. A. A portion of the vent ral salivary glamels and duct in Alexandromenia agasizi. 


PLATE 27. 
PL.1TE 27.

Figs. 1, 2, 4-11. Cross sections of Chaptorlenna montereyensis. $(X+40$.$) Fig. 3. C. nanula.$

Fig. 1. Through brain region.

Fir. 23. Through heart and roelonorluets.

lig. 3. Through junction of pharynx and stomach.

Fig. 1. Through rambila.

Fir. 5. Through labio-huecal ganglia and glands entering pharynx.

Fige. i. Thromgh heart and eoelomoduets.

Fig. 7. Dorsu-demininal sense organ.

Fig. s. Thrumgh suprarectat commissure.

lige. 9. Throngly outled, on left, of coetommlued.

Fig. 10. Through junction of pharynx and stomark.

Fig. 11. Through brain and anterior buceal plate of small specimen. 


PLATE 28. 
PLATE 28

Figs. 1-6, 8, 9. Cross sections of Chaetolerma hawailensis. $\times 55 ;$ Figs. $7,10-12$. Chactulerma nanula. $\times 33$.

Fig. 1. Through brain ancl buccal plite.

Fig. 2. Through rarlula.

lig. 3. Through junetion of pharynx and stomach.

Fig. l. Through suprarestal iommissure.

lig. 5. Through hoart and coelomorluets.

lige. 6. Through outlet of coelomoduet, on left, atme origin of pericardial npening.

Fin. 7. Through brain region.

Fig. 8. Through posterior enth of prothorax.

Fig. 9. Longitudinal section of posterior enul.

Fig, 10. Sesetion through ontlet of cordommluet, on left.

Fig. 11. Through radulat.

Fig. 12. Through suprarectal commissure. 



$$
\text { - }
$$


PLATE 29. 
PLATE 29.

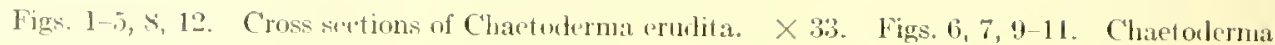
scabra. $\times 20$.

Jige. 1. Through heart and corlumoluets.

lig. 2. Chose to junetion of phorynx aud stomach.

lig. 3. l'mstrion ent of prothorax.

lig. 4. "Through liraill.

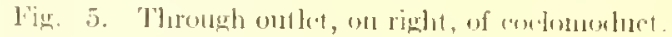

ligr. bi. suprarestal commissure.

Fig. 7. 'lhorough gills and cloacal dhambur.

Fin. s. Through rachula.

Fig. 9. 'Through junetion of pharynx antl stemlatl.

Fir. 10. Throughth heart and welomochuts.

Fin. 11. Thlough pesterior end of prolhor:tx.

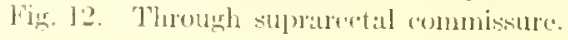




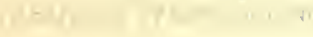
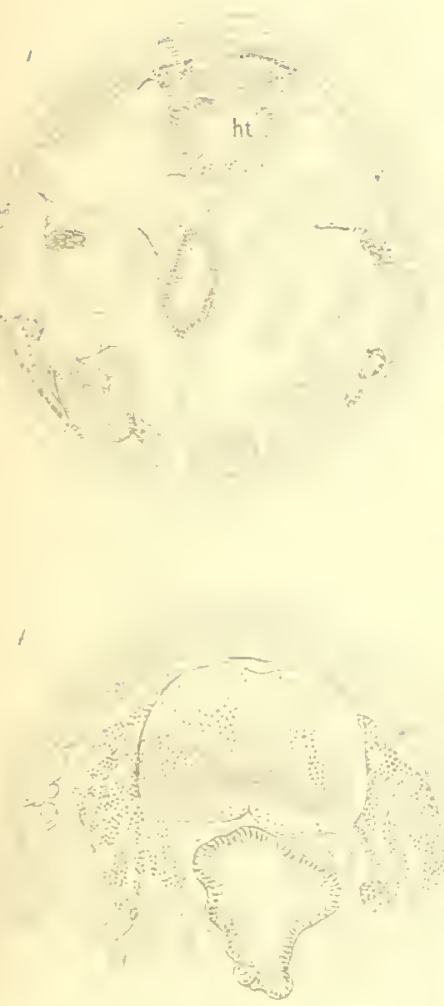

S

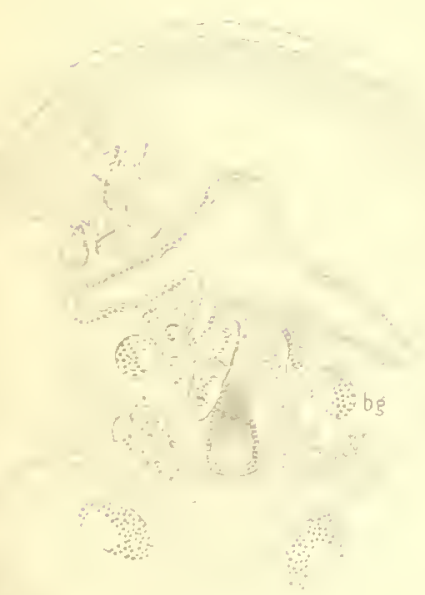

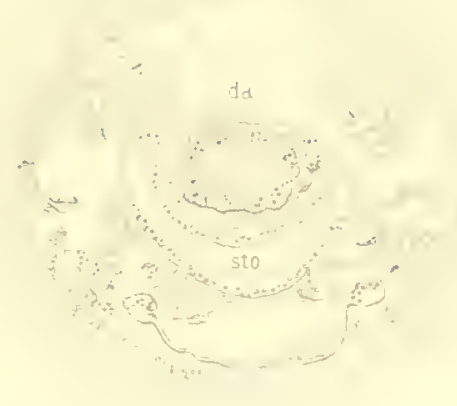

tov

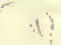

(1) 

PLATE 30. 
PLATE 30

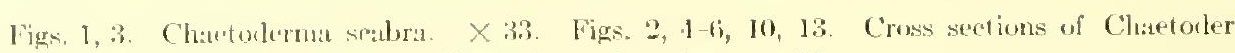

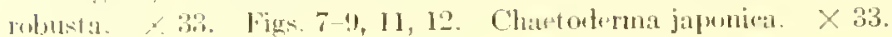

Fig. 1. Through brain region.

Fie. 2. Through radula.

Fix. 3. Same. Through radula.

Fig. 4. Through brain region.

Fig. 5. Throngh suprarental commisenre.

Fig. ti. Throegh posterior end of protherix.

Fig. 7. "Though outtert, in left, of "relomorluct.

Fig. $s$. Through heart and roelomoducts.

Fig. !). Through suprarectal commiswire.

Fig. 10. Througl junction of pharyux and stomach.

- Fig. 11. Throtgl posterior end of prothorax.

Fig. 12. Through junetion of pharynx and stomarh.

Fig. 13. Through mitlet, on left, of coetomodurt. 

it demands no deseription. Posteriorly the gut narrows rapidly, beemes somewhat roctangular in aros section as it pastes between the limbs of the shell gland, and shortly before its outlet in the cloaea develops moderately high folds.

The periendlial cavity is of very large size (1'ate 18, figs. 2, 3), and the contained heart is of the usual greatly elongated type. There are no distinct signs of a division into auricle and rentricle though a valve-like flap near its anterior end may indieate surh or possibly the commencement of the aorta, which for a considerable distance is of as great diameter as the heart itself and even in the head region cont inues of lange calibe (Plate 18, fig. 1). It s relations to the gonad and visceral (atrity are similar to what ocems in S. triangularis. In the posterior part of the body the channels are more than usually ill defined, but the course of the blood is essentiatly the same as in the other species of the genus. The corpuscles possess the characteristice elliptical or pointed ovate form, and are accompanied by a relatively large number of leucocytes.

The gonad is fully developed, of relatively latge size and the sex products are arranged in the customary fashion. Throughout its entire extent, but especially in the posterior half of the animal, the normal reproductive elements are associater] with large masses of eggs in all stages of degeneration. This may be due to post mortem changes, but the shaply defined rharacter of the various stages of the spermatozoa, ova, hlood mompuscles, and other collular elements in various parts of the body argues against such a virw. In some species of Chitons (e.g. Ischnochitom magulenensis) a considerable number of ova do not pass to the exterior during the cog-taying process, but undergo disintegration and are absorbed. Appearances inclieate that this is the state of affairs in the present species, and the almost empty condition of the seminal reoptacles further indicates that the breeting seasm has passed.

The duets leading from the perieardial cavity are relatively tender though they entarge somewhat before entering the shell gtand, and as the cells change from a cubical to a eolumnar form they beeme increasingly ghandular. An unusually large number of seminal vesicles are present, iwenty-three ocemring on the side of the body represented (Plate 9, fig. 1). In these the distal, usually vesicular portion in exceptionally small (Plate 18, lig. 4) lut the diameter may be somewhat increased when the organs are filled with sperms. These bodies are attached not unly to the forward ond of the shell gland hut several of them open into the clorsal section of the gomoduct. The component eells are columnar and show at various points faint signs of glandular antivity. The shell gland on the other hand is highly ghadular, more than usually irrogular in outline and as 
usual in the genus unites with its fellow of the opposite side so elose to the cloaca that two openings appear to be present. The eells are all of columnar form and are of one type judging from the darkly staining gramular secretion. Is in other species of the genus a diverticulum of the eloacal wall is present ventral to the outlet of the shell gland, but there are no indieations that it is of any especial signilicanee.

In the other species of the genus Strophomenia deseribed in the present paper there are from few to many diverticula extending outwardly from the cloacal wall, but they never reach the excessive development existing in this species. These are shown, somewhat diagrammatically (Plate 9, fig. 1). The cells are usually columnar and are filled with a finely granular substance which in various places is in the act of escaping into the cloacal cavity.

The brain, clearly bilobed, is located against the under side of the intestinal coecum at the level of the posterior border of the atrium (Plate 8, fig. 5). From it the usual three pairs of nerves originate, that after branehing unite with gaughionic masses attarhed to the hases of the cirri or without such union pass to the body wall. The eonnectives to the lateral, pedal, and labio-buceal systems arise in the eustomary situations and the relations of the ganglia themselves, so far as they have been detemined, are typieal. Pedal commissures and latero-pedal connectives oceur at frequent, though not perfectly segular, intervals and a corresponding number of unusually heary nerves arise from the dorsal surface of the lateral ganglia. These have in several cases been followed elose to the mid dorsal line but that they form commissures is not assured. They probably innervate the neighboring somatie musculature and hypodermis.

Posteriorly the pedal cords, united by commissures to the anterior cloacal wall, branch repeatedly in this last named locality and innervate the body and eloaeal walls and some of the fibres beeome imbedded in the shell gland. The lateral cords at this same level likewise branch repeatedly and supply the same structures as the pedal, thomgh more dorsally, and in addition give off a few small nerves that attach themselves to the pericardial wall. A very few branches from these last named nerves have been traced a short distance into the heart. The pedal and lateral cords are posterionly united by one delicate branch; others may exist, but the nerves are not sufficiently differentiated from the surrounding tissue to permit of their being followed for any considerable distance. It is a peculiar fact that no trace of a dorsal posterior commissure uniting the lateral eords has been found to exist.

The labio-buecal connectives arise to the inside of the connectives leading 

PLATE 31. 
ILATE 31 .

Figs, 1-4, $7,8,10$. Cross sections of Chartoderma califormena ( $\times 33$ ) Figs. 5, 6. Cliteto

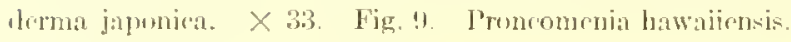

Fig. 1 Through ratula.

Fig. 2. Through junction of pharynx ant stomart

Fire. 3. Through heart and roelomorhucts.

Fig. 1. Through brain region.

Fig. 5. Through brain of Chactuterma japonira.

Fig. 1i. Througl rarlula, samo species.

Jig. 7. Through outlet of eorlemoluct, om loft.

Fig. S. Pharynx :mol glamds in front of ramlinla.

lig. 9. External suscory atrial ridge of Pronomenial hawaiiensis; os, riflge resting upon ganglinn cells; om, onter at rial ridge; ", cirrus.

Fig. 10. Through suprarect al commistare 

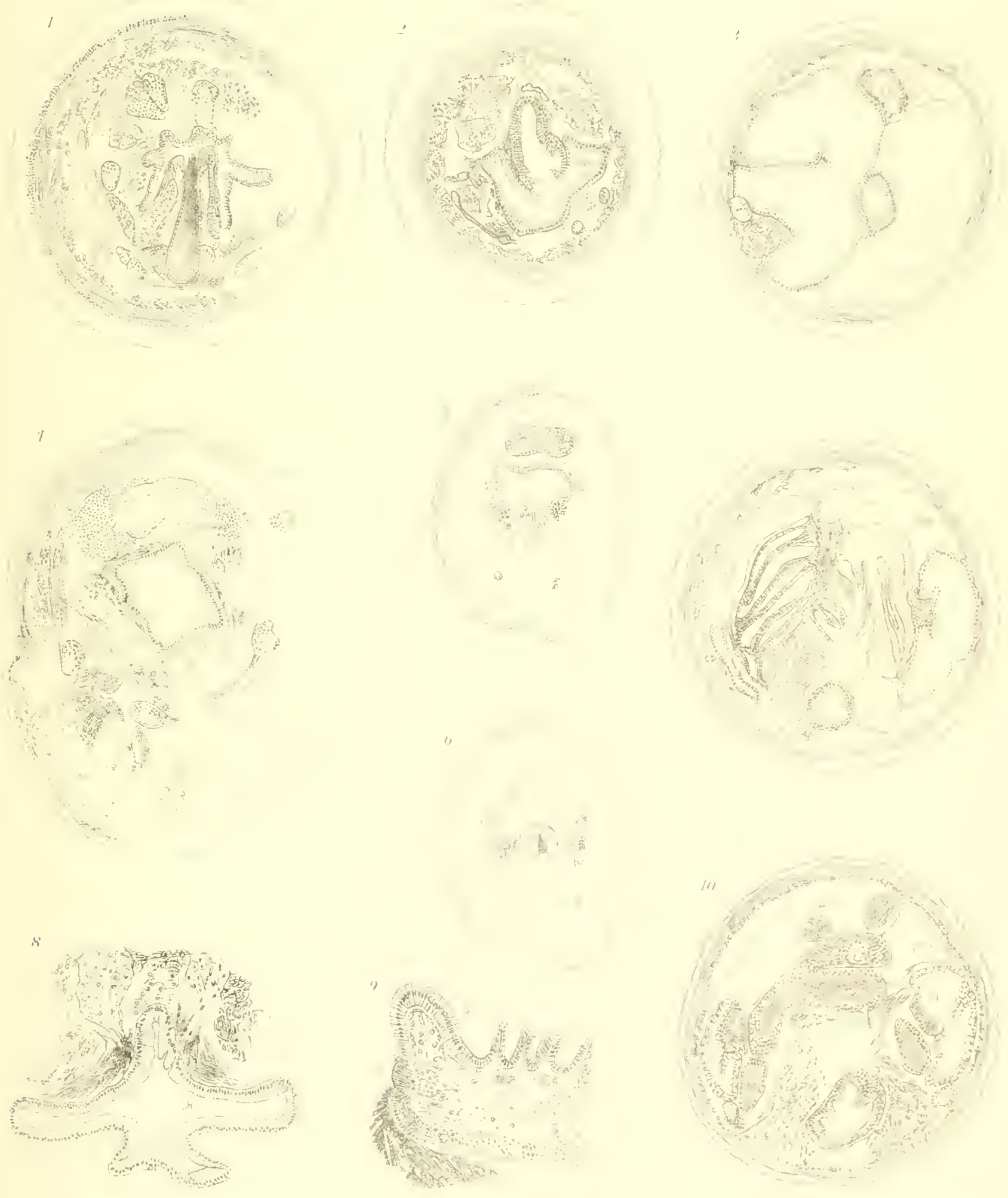

PLATE 32. 
PLATE 32.

Cuticle and hypotermis from side of head unless otherwise stated.

Fig. 1. Ilypodermis and its products in Strophomenia spinosa, large specimen. $\times 205$.

Fig. 2. Same in Lophomenia spiralis. $\times 255$.

Fig. 3. Same in strophomenia scandens. $\times 155$.

Fig. 1. Same in Halomenia gravida. $\times 225$.

Fig. 5. Perforation of the somatie musculature in $\mathbf{H}$. gravida by a diverticulum of the mid gut which comes in eontact with a modified hypodermal papibla; s, blood sinus. $\times 255$.

Fig. 6. Hypurlermis of Drepanomenia vampyrella. $\times 255$.

Fig. 7. Same of lehthyomenia porosa. $\times 330$.

Fig. 8. Same of Dontersia californiea. $\times 555$.

Fig. "3. Siection through the dorsal sense organ of strophomt nia seantlens. $\quad \times 300$.

Fig. II) Same of Proneomenia hawaiensis; ne, nerve. $\times 180$.

Fig. 11. Same of Lophomenia spiralis; ne, nerve. $\times 150$. 

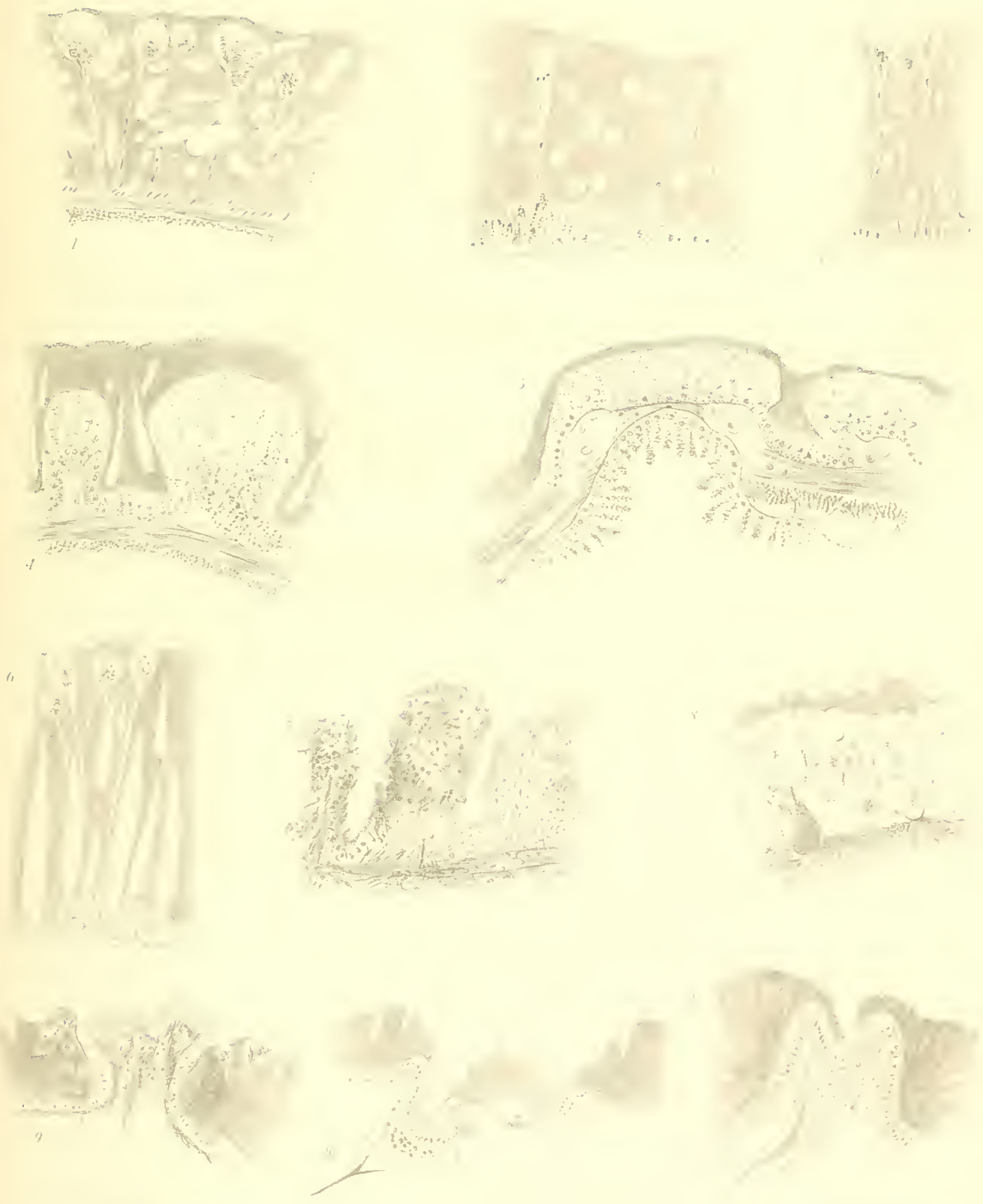
PLATE 33. 
PLATE 33.

Cutiele and lyporlermis from side of head unless otherwise stated.

lig. 1. Stroplumenia triangularis. $\times 200$.

Fig. 2. Strophmenia fareimen. $\times 300$.

Fig. 3. Proneomenia lawaiensis. $\times 300$.

lig. 4. Dorymenial acuta. $\times 3330$.

Fig. 5. Alexantlromeniat agassizi. $\times 200$.

Fig. 6. Pronemenian insularis. $\times 400$.

Fig. 7. Stroplomeniaspinosa, dorsal sisle. $\times 200$.

Fig. 8. Alexantromenia valitia. $\times$ 2600.

Fig. 9. Strophomenia ophidiana. $\times 200$. 


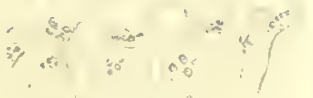

$\therefore \frac{1}{1} 11$ a

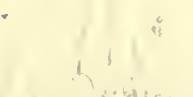

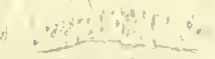

$-4$

I

$1-10,3^{3}+\cdots, 10$

$\%$

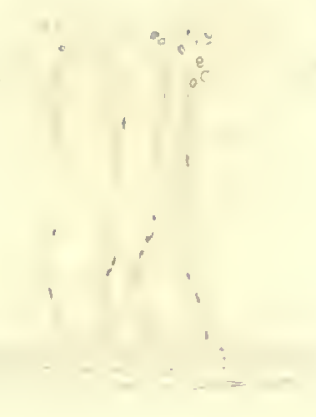

T- m

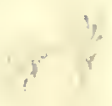



PLATE 34. 
I'LATE 34

Fig 1 Cross soction through radula sac of Lophomeniat spiralis. $\quad x \quad 56$.

Fig. 2. Lengitulinal section throngh radula and subralular organ of Proneomenia hawaiensis. $\alpha x(1)$

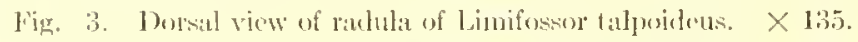

livg. 4. Two rows of teeth of Strephomenia triangularis. $\times 330$.

J"ig 5. Portion of radula of Mlexanelromenia agassizi. $\times 255$.

17ir. 6. Sirde view of radula of Limifosor talpoideds. $\times 135$.

Fig. 7 . Teeth of Jorymenia acuta (mill line to left). $\times 330$.

The s. 'Terth of st rophomenia spinosil, large individual. $\times 555$

Fïg. 9. Sime specius, small indiviełual. $\times 330$.

Fig. 10. Samesperies, sinatl inclivislual. $\times 330$.

1'iz. 11. Side view of teeth of Dorymenia acuta. $\times 330$.

lig. 12. Cross section of radula of Halomenia gratvida. $\times 330$

Tig. 13. Proncomenia hawailensis, showing 7 of the to leeth of each transverse row; $m$, mid line. $\times 2.5$.

Fix. 14. Tooth of Alexandromenia valida. $\times 2010$.

Fig. 1.i. Portion of ralula of strophomenia fureinen. $\times 25 \overline{5}$ 

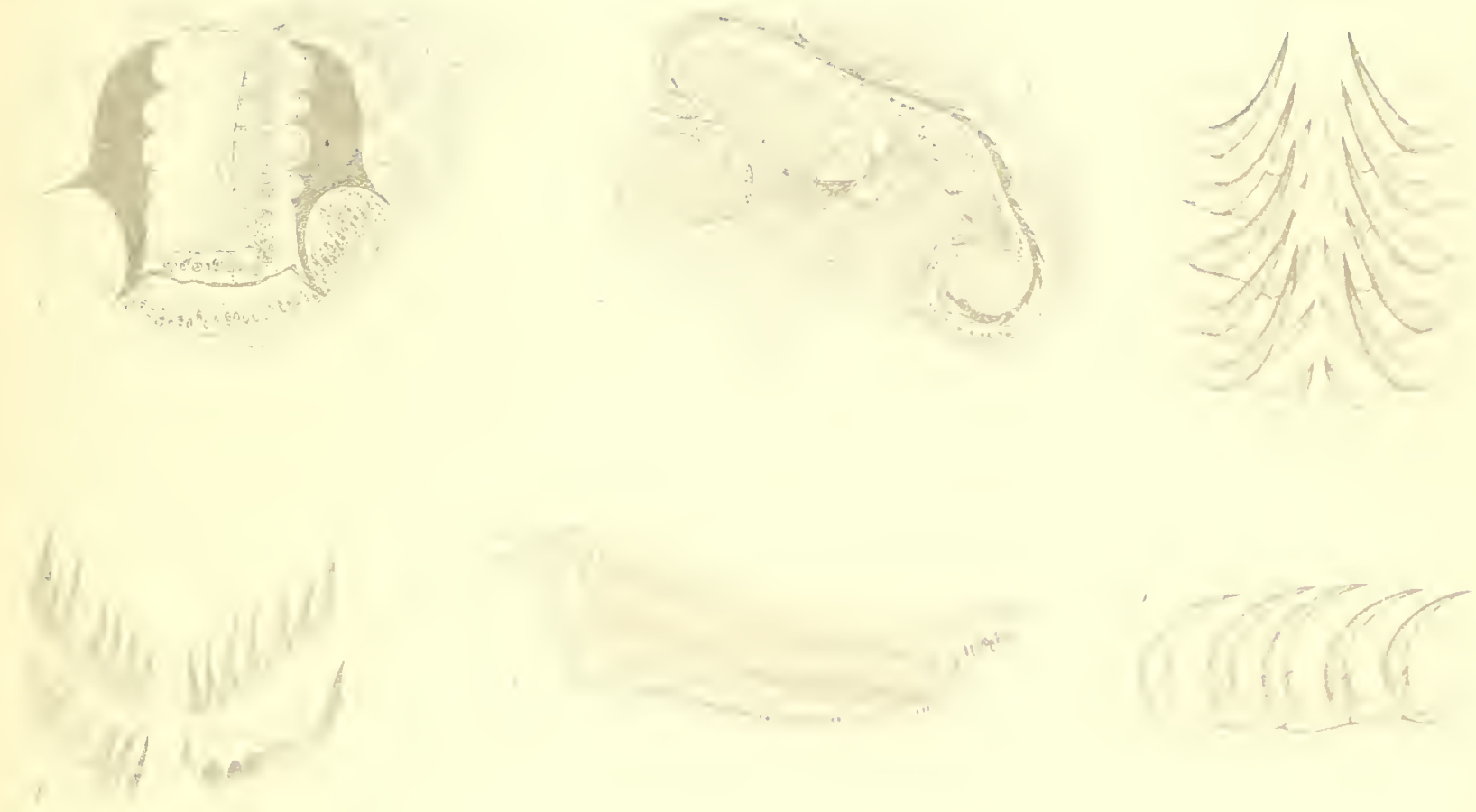

is

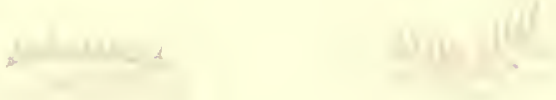

(4),

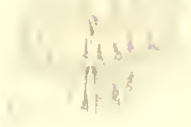



PLATE 35. 
I'LATE 35.

Fig. 1. Limifosor fratulit. Fintion through region of salivary glanels. $\times 28$.

Fig. 2. Fame through muste 17 (fig. 4, pl. 10).

Fig. 3. Same through posterior end of radula support. $\times 28$.

Fig. 4. Siame in region of heart.

Fig. 5. Same through opening of digestive glank.

Figx. 6, 7,6 . Development of ava in 1 ferponenia platypoda. In fig. is the nuclei of probable folliele erlls ( $f(0)$ are intart; in fig. 7 the membrane has dissolved aml the scattered ehronusomes are heeming vesicular; in fig. "t the ormm is almust mature and the vesickes (cr) of relatively large size. $\times 5.55$.

lige. S. Longitulinal section thongh region of radula of Chactoderniat erudita, showing subratlular ganglion, sn. $\times 135$.

Fig. 10. Seretion tlirough brain of Limifossor fratula. $\times 28$.

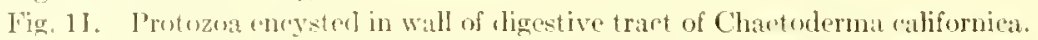

ligg. 12. Surtion throngh dorsu-terminal sense organ of Dondersia callifornica. $\times 333$

Fig. 13. Thoot corpuseles of l'roneomeniz hawaiitensis. $\times 450$.

I'ig. II. Seetion through Pronenmenia insularis. 

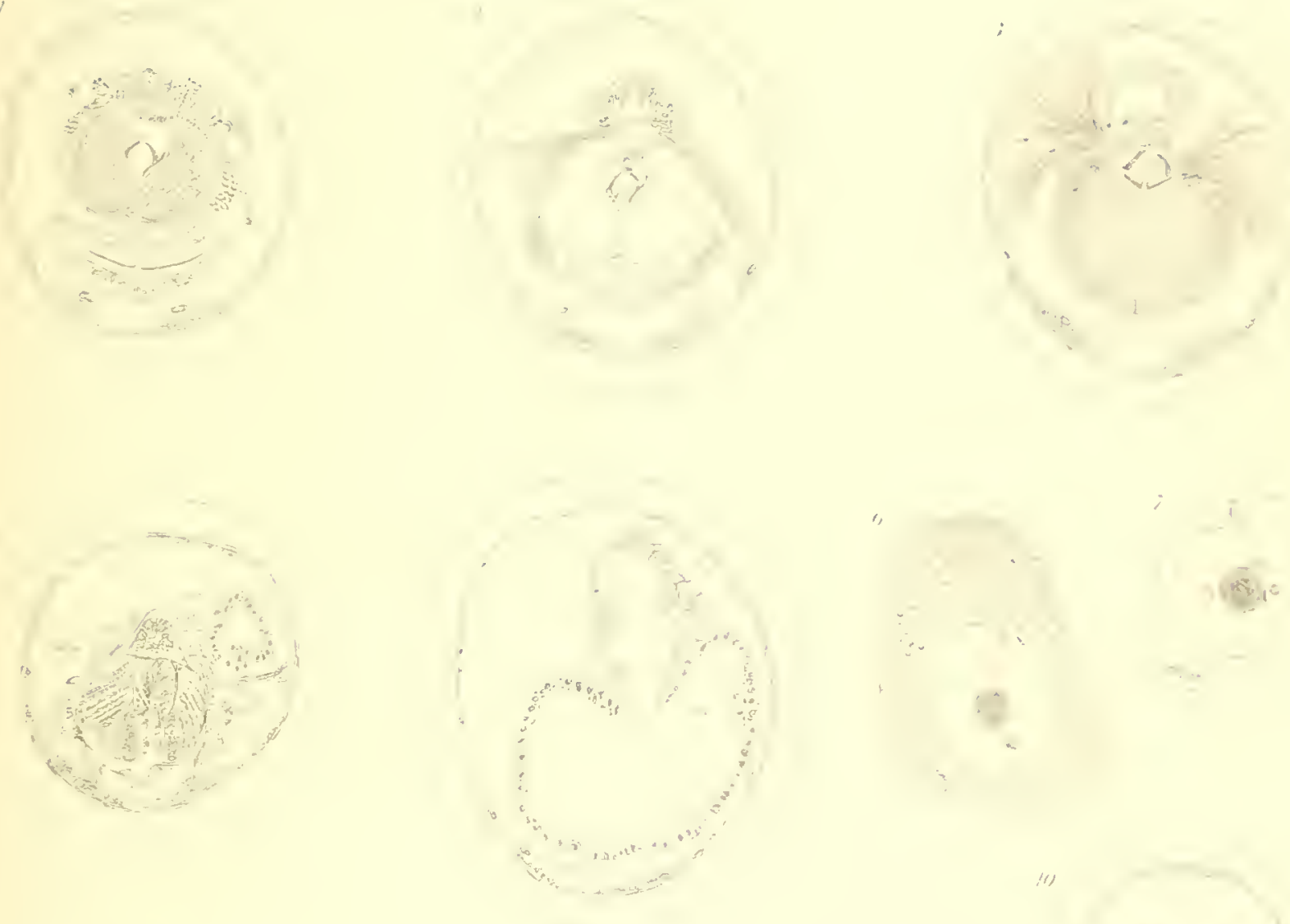

(1) 10

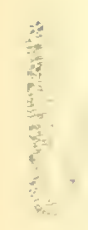
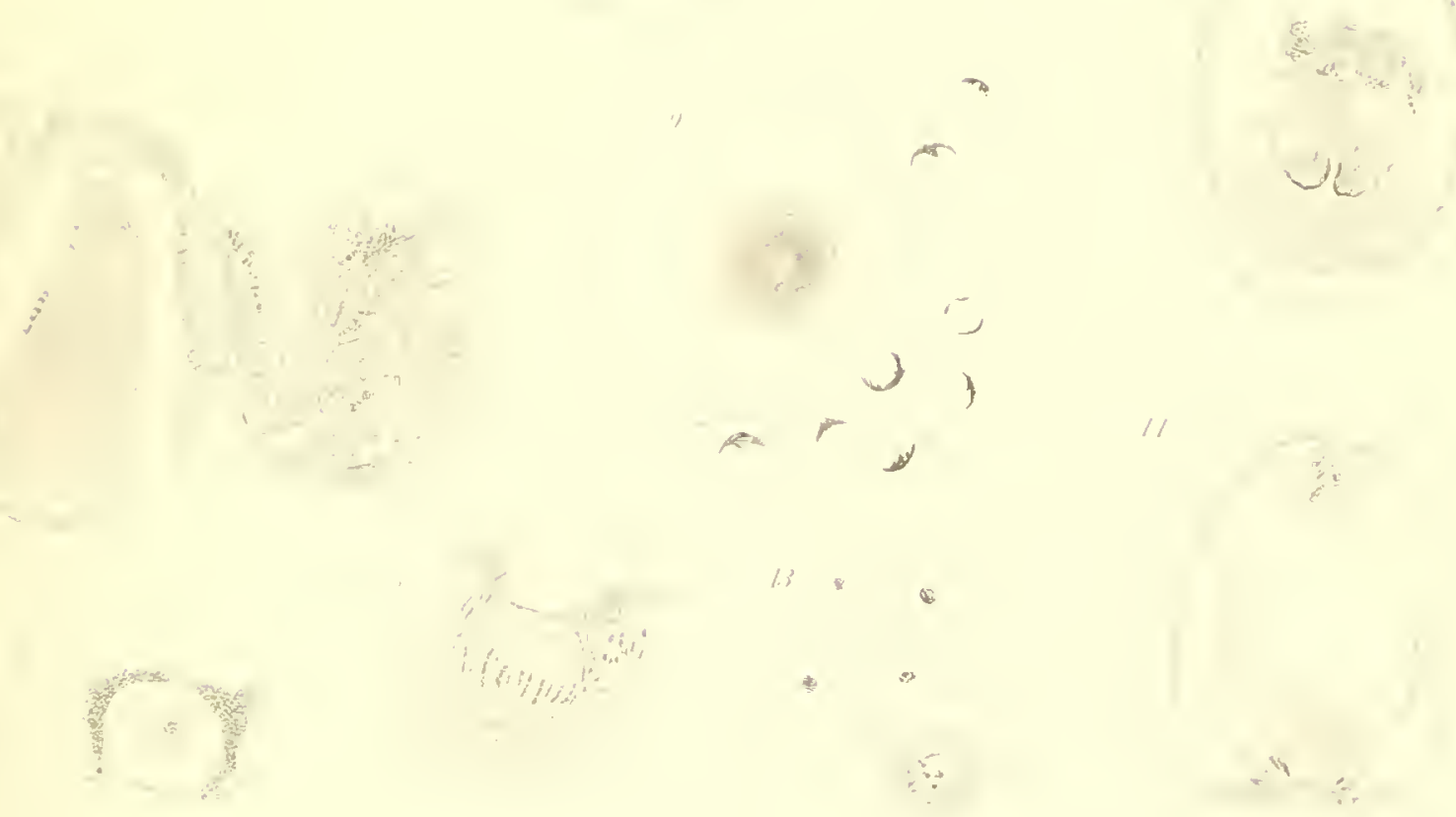

U 
PLATE 36. 
PLATE 30.

Fig. 1. lieronstruction of posterior and of Chaptoderma argentea.

Fig. 2. Sane of Chachlerma attenuata.

lig. 3. Ailvaned stige in spirule tevelopment, the matrix rells retaining their attachment to the spine. Proneontenia hawailensis. $\times 555$.

Fig. 4. Somewhat earlier stage than fig. $3 . \times 55$.

Fir. 5. Completion of spicule development amb commenenwnt of slyifting of matrix crils. $\times 555$.

lije (i. Reconstruction of anterior end of strophomenia triangularis.

Fig. 7. Early stage in derelopment of spine in Pronconumia hawaiiensis. $\times 555$.

Fig. $s$. Hyportermis in Limifoseor fratulia. $\times 2.5$.

Fig. 9. Posterior (nd of Alexamdromenia agassizi. $\times 3$.

Fir. 10. Papilla and ontlet of salivary gland in 1 . agassizi.

Fig. 11. Very early stage in development of spine in Proneonenia hawaiensis. $\times 555$.

Fig. 12. Blood corpuseles of sitrophomenia scindens, $\times 450$.

Fig. 13. Same of Clactoderma hawaicnsis. $\times 450$.

Fig. 14. Same of Lophomenia spiralis. $\times 450$.

Fig. 15. Spines of Strophomenia iriangularis. $\times 150$.

Fig. 1f. Same of Strophomenia spinosa. $\times 205$.

lig. 17. Same of St rophomeniat ophicliana. $\times 205$.

lig. 1s. Completed development of radially diroted spine of Proneomenia hawaiiensis; and (leveloping papilla. $\times 55.5$.

Fig. 19. Base of gill plates and attarled glamel erlls (g*), Alexandromenia agassizi; ne, nerve. 


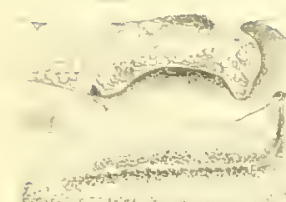

ty
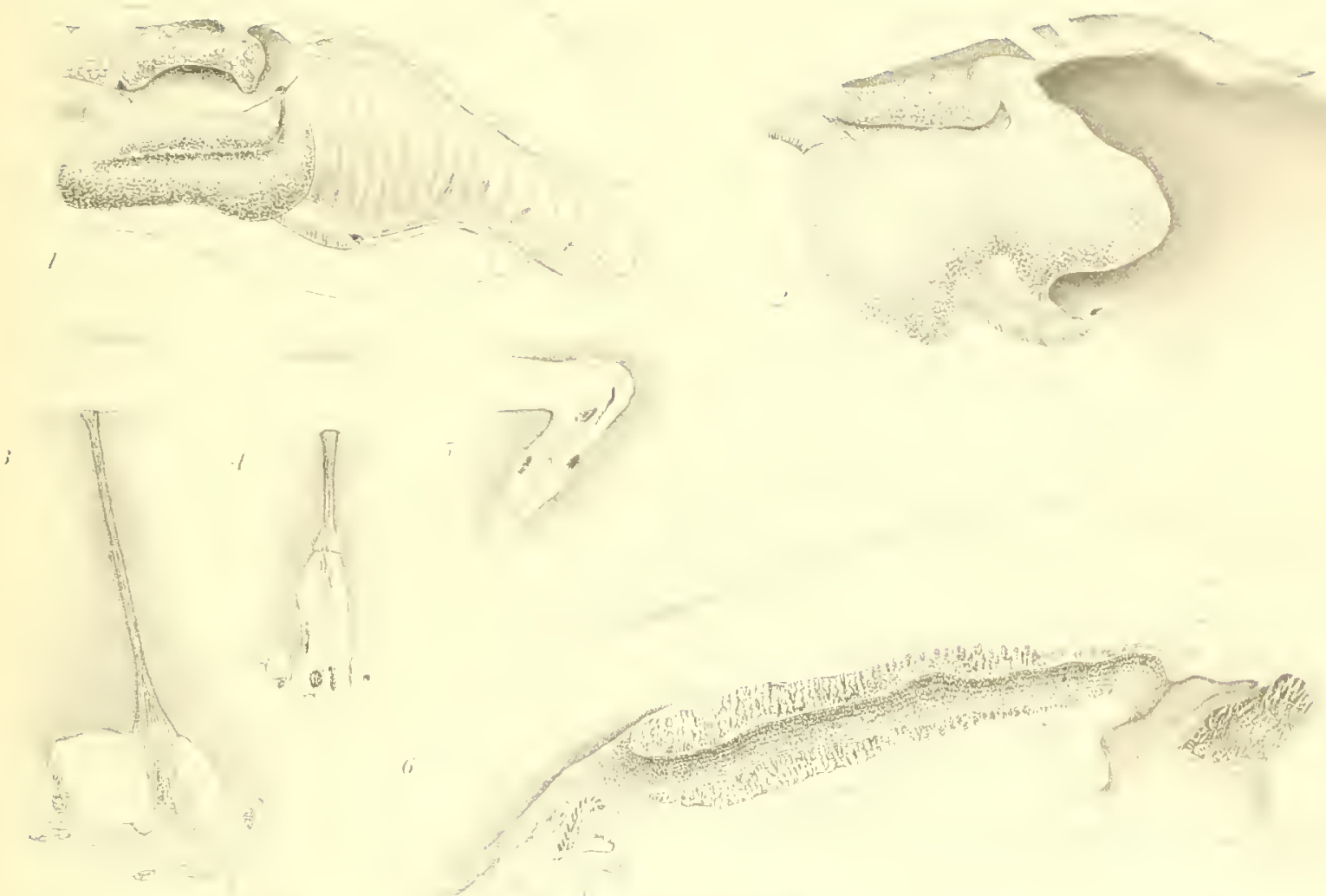

a n

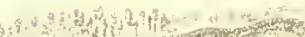

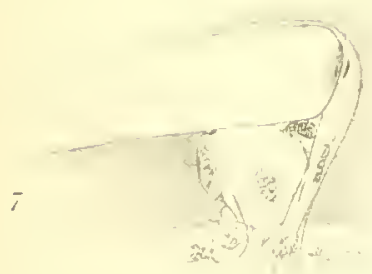

is

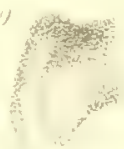

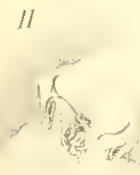

?

I.

()

$\rightarrow-4$

$6 . ;$

$+2$

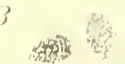

謷

11

\& 
PLATE 37. 
PLATE 37.

17g. 1. Spicules of Ichthyomenia porosil. $\times 480$.

Fig. 2. of Chaetodermi montereyensis, small specimen. $X$ so.

Fig. 3. Of Chatorlema monteryensis, hatge specimen. $\times 80$.

Fig. 4. of Chatoderma robustia $\times s 0$.

Fig. 5. Of Proneomenia hawitiensis. in $\times 330 ; 1, \times 130$.

lig. 6. of Chaeterlerma argentea. $\times 135$.

Fig. 7. Of Drepanomenia vimpyrella. $\times 135$.

Fig. s. (of chatodermit attenuata. $\times 135$.

Fig. 4) (If Alexandromenia agassizi. $\times 335$.

Fig. 10. of Dorymenia aruta. $\times 135$.

Fig. 11. Alexandromenia vialidil. $\times 1,0$.

Fig. 12. Of Chaetoderma hawailensis. $\times 255$.

Fig. 13. Of Lophomenia spiralis. $\times 335$.

Fig. 14. Of Chatederma ealifornica. $\times 135$.

Fig. 15. Of Chaetolerm: erulitı. $\times 135$.

Fig. 16. Of Proneomenia insularis. $\times 135$.

Fig. 17. Atrophomenia seandens. $\times 300$.

Fig. 1s. (If Chaetorkrma nitnula. $\times 135$.

Fig. 19. of Chactoulerma sealora. $\times 100$.

Fig. 20. Of Chaetorlerma sp.? Inidentified fragment, Alaska. $\times 135$. 

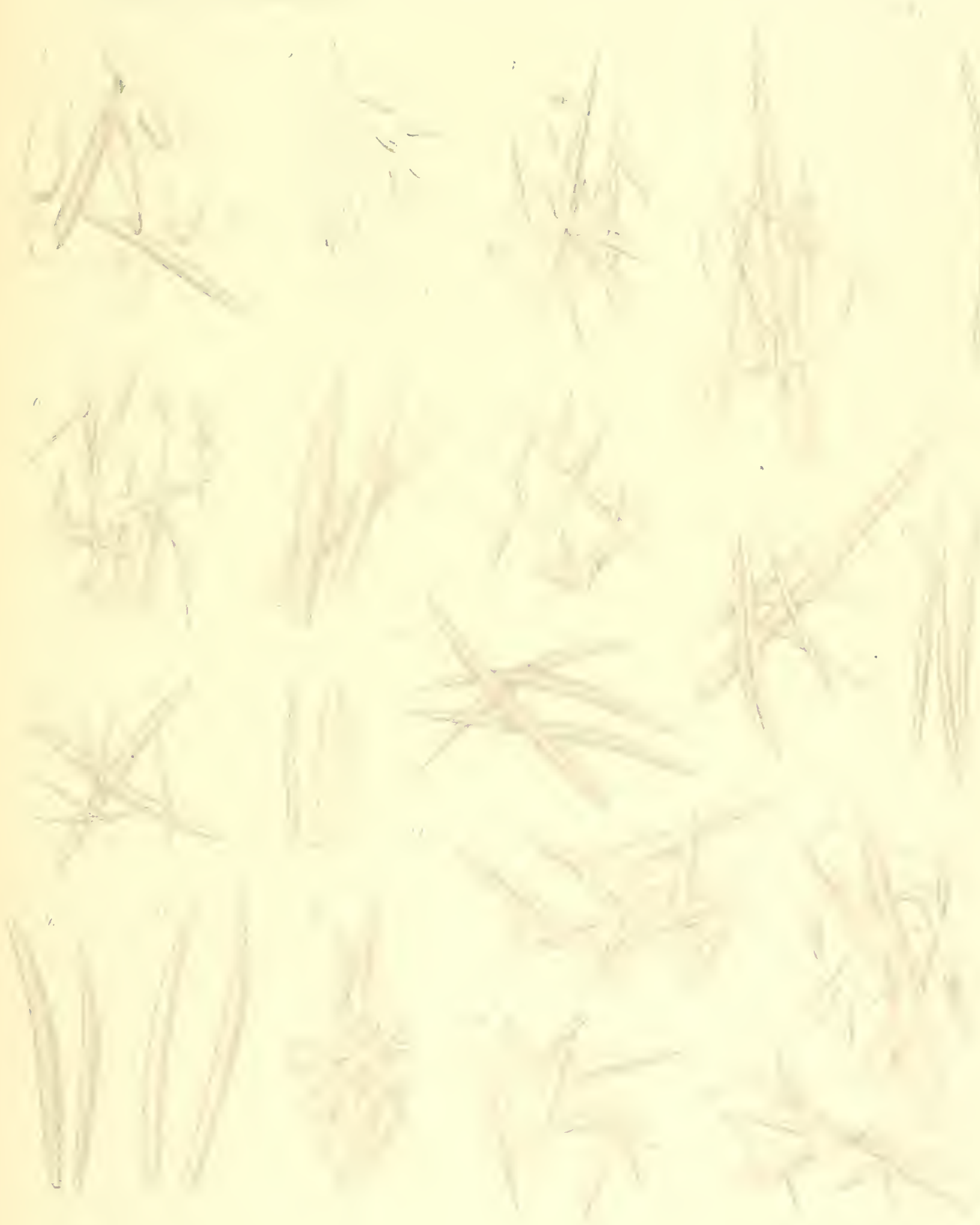

PLATE 38. 
PLATE 3S.

Fig. 1. Reconstruction of anterior end of Driomenia pacifiea.

Fìg. 2. Sime, posterior end.

Fis. 3. Entire animal enveloped in suall portion of hydroid colony, fortularella sp. $\times 5$.

Figs, 4, 5, 6, 8. Sertions along lines $A, C, B, D$, in fig. $1 . \times 50$.

Fies. 7, 9. Along lines E, 1 , of fig. $2 . \times 50$.

Fig. 10. Section of hypoderuis and eutiele. $\times 260$.

Fig. 11. Same of Pachymenia albyssorum. $\times 60$. 

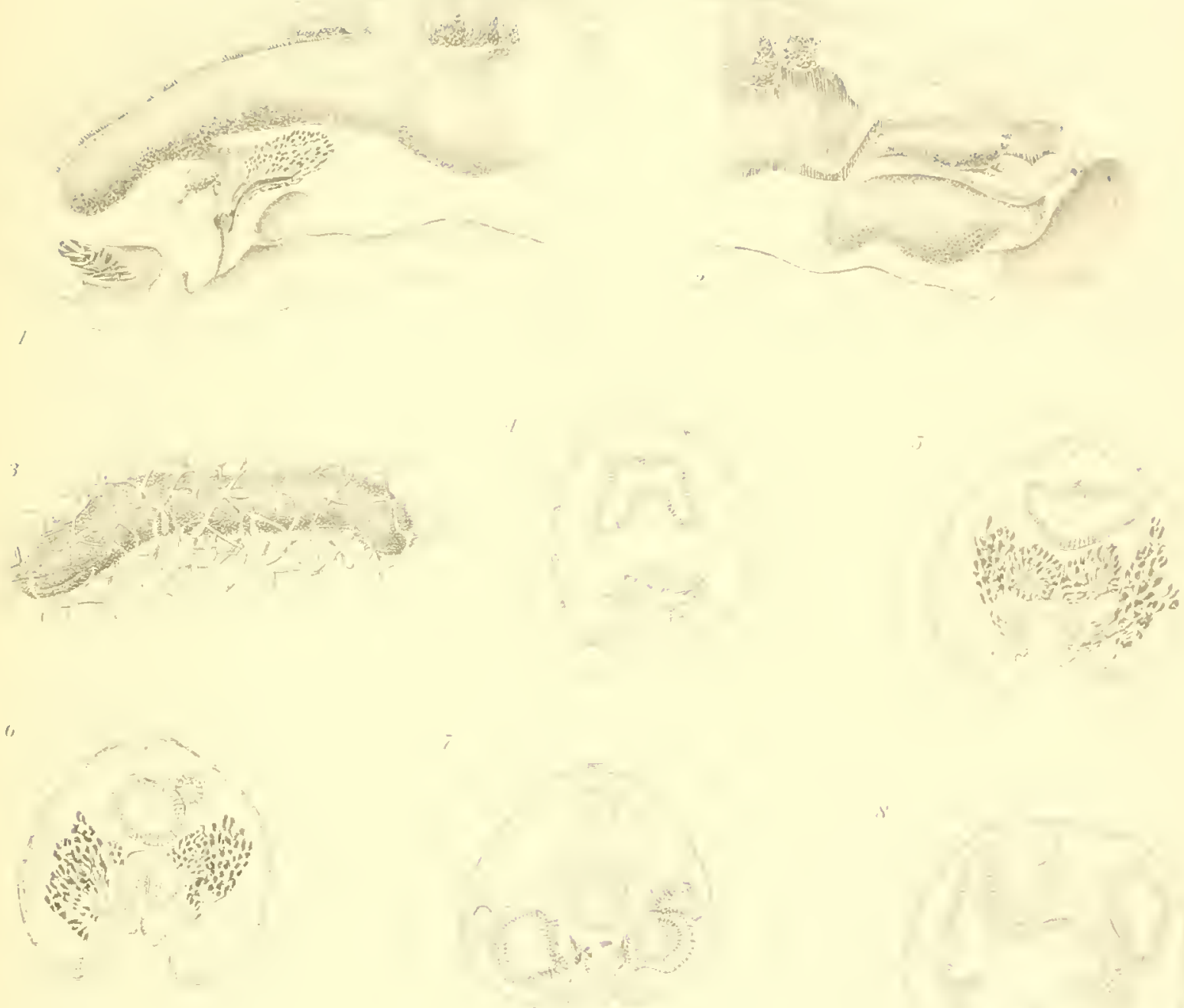

$$
\text { ty }
$$

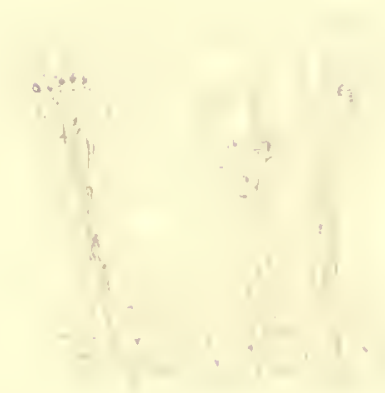


PLATE 39. 
PLA'E 39.

Fig. 1. Roronstruction of anterior end of Pachyomenia alyssormm.

Fig. 2. Sinue, posterior encl.

Fig. 3. loot, sime species, in midllle of borly.

Fig. 1. Pawhymenia albysorum. $\times 3$.

Fig. 5. Sines of Driomenia paeifiea.

Fig. $6,-S$. Serctions of lachymmia ahyssorum aloug lines B, D, fig. $1 . \quad \times 25$.

Fig. 7. Section of Drionenia parifica along line $\mathrm{G}$, fig. 2, pl. $38 . \times 50$. 


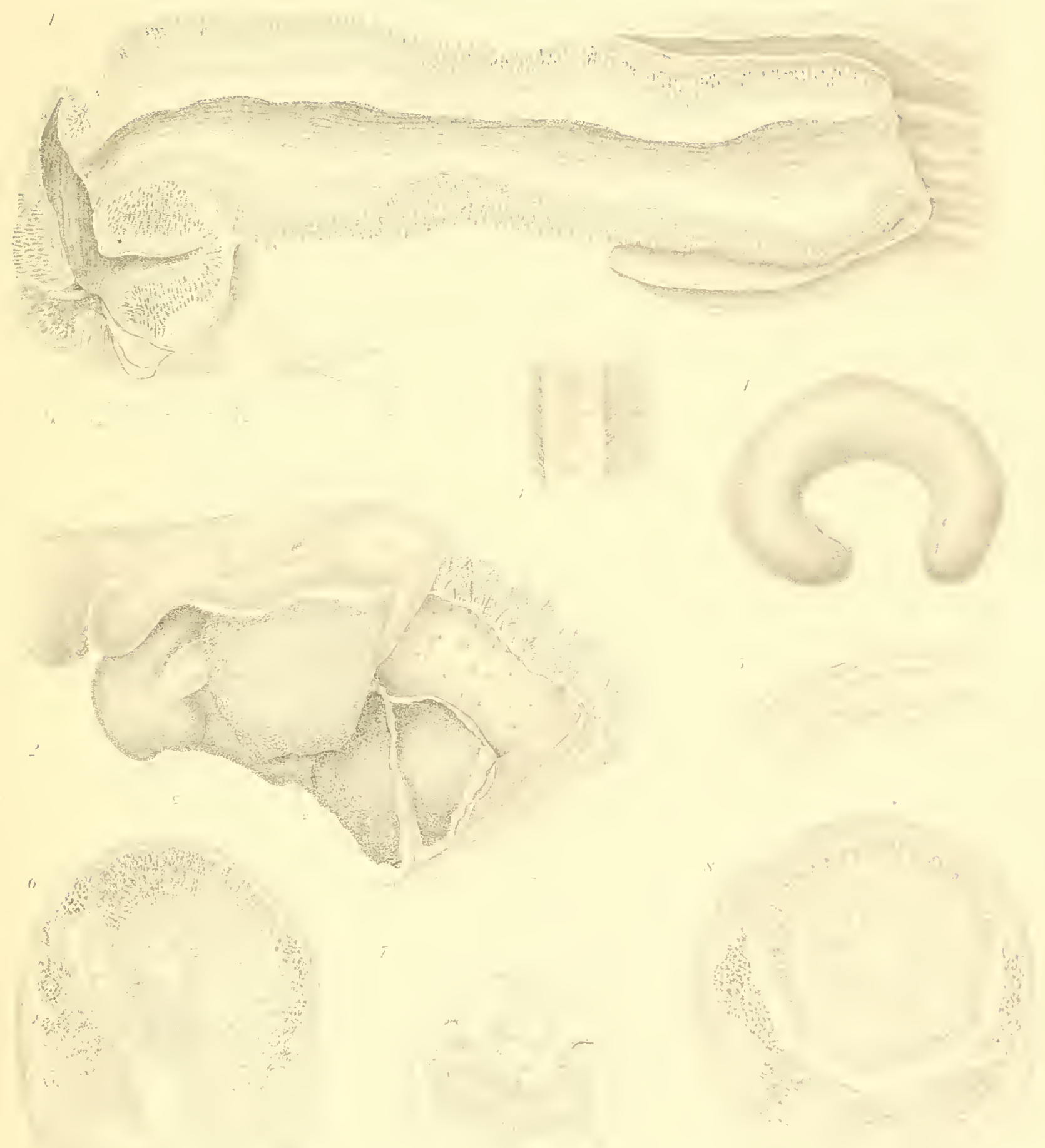


PLATE 40 
I'LATH 40.

Fiess. 1-1, 6-10. Cross sections of Pachymenia alyssormn. Fig. 5, Driomenia parifira. liges. 1, 2, 1, 7, alcher lines E, F, ( i, I1, posterior ent. $\times 25$.

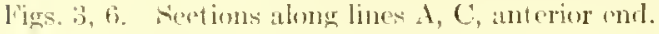

lïg. 5. Sertion of Dronentia along line H, fig. 2, pl. 38.

ligy S. Spines of Pachymenia abysiorum. $\times 140$.

Fig. 9. Seetion albout the posterior end of gonad.

liig. 10. Sheetion through bouly behinel phargix. 


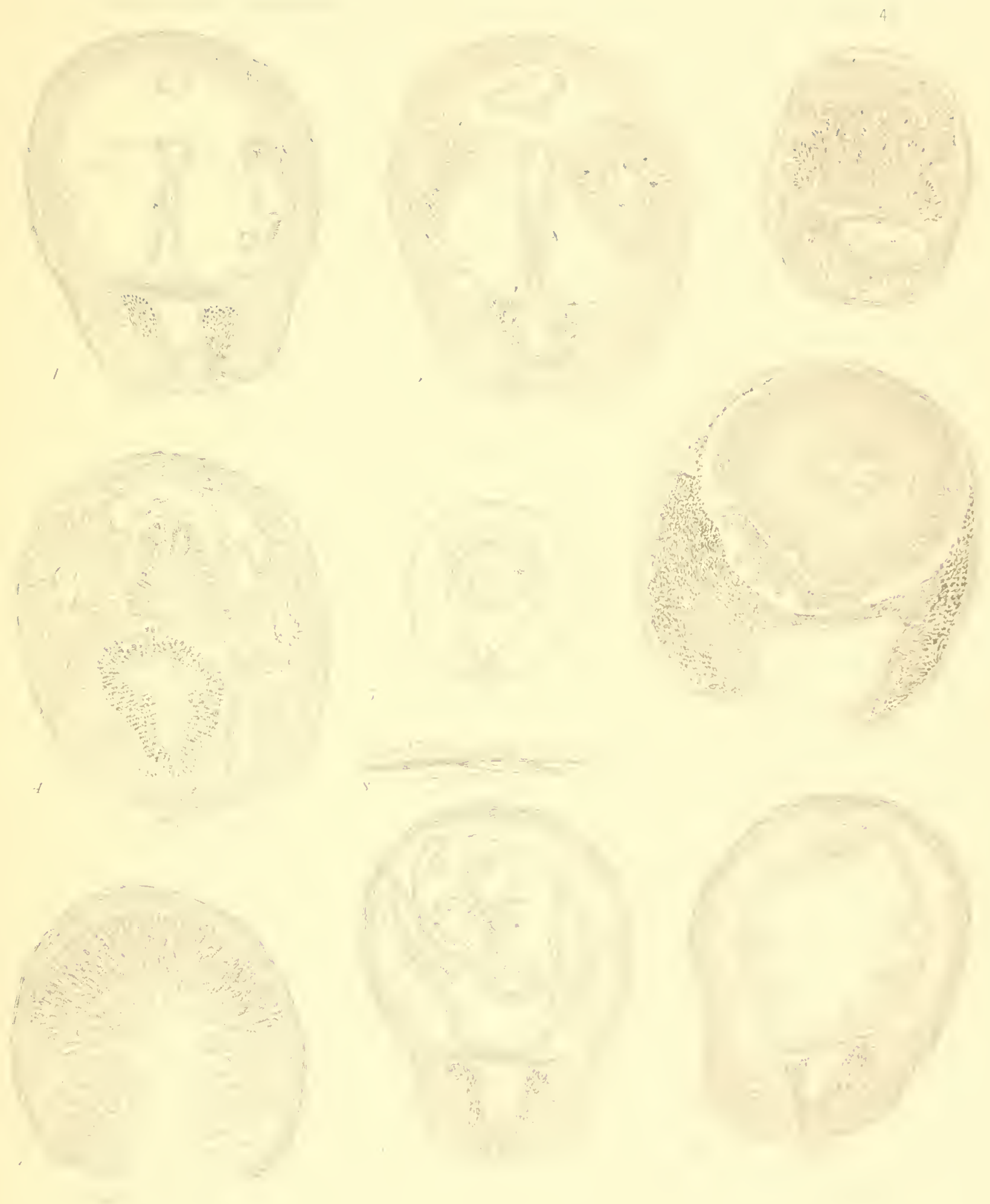





\title{
PUBLICATIONS
}

\author{
OF THE
}

\section{MUSEUM OF COMPARATIVE ZOÖLOGY}

\author{
AT HARTARI COLLEGE.
}

There have been published of the Bulletin Tols. I. to LII.; of the Menorns, Vols. I. to XXIT., and also Vols. XXTi., XXYiII., XXIX., XXXi. to XXXil., XXXYII., and XLI.

Vols. LIII. to LT. of the Bulletin and Vols. MAY., XIVII.,

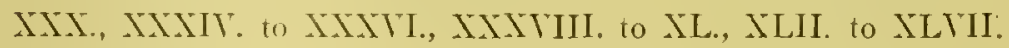
of the MExiorss, are now in course of publication.

1 price list of the publications of the IIuseum will be sont on application to the Curator of the Museum of Comparative Zoölogy, Cambridge, . II ass. 


